\title{
THE LORDS OF THE AUSPICIOUS CONJUNCTION: TURCO-MONGOL IMPERIAL IDENTITY ON THE SUBCONTINENT
}

\author{
A Dissertation \\ Presented in Partial Fulfillment of the Requirements for \\ the Degree Doctor of Philosophy in the \\ Graduate School of The Ohio State University \\ By \\ Lisa Ann Balabanlilar, M.A. \\ $* * * * * *$ \\ The Ohio State University \\ 2007
}

Dissertation Committee:

Professor Stephen Dale, Advisor

Approved by

Professor Jane Hathaway

Professor Geoffrey Parker

Advisor

Graduate Program in History 
Copyright by

Lisa Ann Balabanlilar

2007 


\begin{abstract}
Contemporary studies of the Mughal dynasty in India have long been dominated by nationalist, sectarian and ideological agendas which typically present the empire of the Mughal as an exclusively Indian phenomenon, politically and culturally isolated on the sub- continent. Cross disciplinary scholarship on the Middle East and Islamic Central Asia assigns to the Mughals a position on the periphery. Omitting reference to a Central Asian legacy, scholars instead link the Mughals to the preceding nearly one thousand years of Muslim colonization in India. Yet to insist on a thousand years of Muslim continuity in India is to ignore the varied religious, cultural, and political traditions which were transmitted to the subcontinent by a widely diverse succession of immigrant communities.
\end{abstract}

This study radically re-evaluates the scholarly and intellectual isolation with which the Mughals have been traditionally treated, and argues that the Mughals must be recognized as the primary inheritors of the Central Asian Turco- Persian legacy of their ancestor Timur (known in the West as Tamerlane). Driven from their homeland in Central Asia, the Timurid refugee community of South Asia meticulously maintained and asserted the universally admired charisma of their imperial lineage and inherited cultural 
personality. The imperial success of the Mughals lay in their ability to identify and reproduce in the Indian context potent symbols of Islamic and Timurid legitimacy which allowed them to successfully affirm their political legitimacy and develop a meaningful imperial identity on the subcontinent. Specific institutions and traditions of the Central Asian Turco- Mongol Timurids: succession patterns, interpretation of Islamic law, the facilitation of migrating sufi orders, the role of women and Persianate literary culture, can be identified and traced from the centers of Timurid politics and culture in Transoxiana to the Indian subcontinent, where they were manipulated and adapted by Timur's descendants in order to bolster Mughal political legitimacy. Certain of these cultural threads were so successfully transplanted by the Mughals that they became deeply embedded into the fabric of Indian society, not only supporting Mughal political claims but remaining in place long after the Mughals had lost effective power by the mideighteenth century.

The shaping and defining of the imperial identity of the Mughals in India through the conscious manipulation of the Central Asian legacy of Tamerlane can be seen as a case study of the movement and migration of symbols of legitimacy and the reproduction of identity by a refugee community in permanent exile. In identifying and examining those links this dissertation will position the Mughal dynasty in the center of the early modern Islamic world as the direct successors of a powerful influential political and religious tradition. 
Dedicated to Mufit and Sara Perihan, who have spent the past several years living patiently with Jahangir and Gulbadan and far too many ill-balanced stacks of books. For your love, and your endless encouragement and pride in me, I thank you. 


\section{ACKNOWLEDGMENTS}

I would like to express my most heartfelt gratitude to Stephen F. Dale, my advisor and mentor. Any success I might have as a scholar is due to his enthusiasm, unerring guidance, advice, inspiration and support. Thank you.

Additionally, my thanks to Jane Hathaway, who has offered me years of academic support, the best editing anyone could wish for and warm friendship. I would like to thank Geoffrey Parker for his insight, guidance and encouragement and, most importantly, his wonderful intellectual curiosity.

I am indebted to Carter V. Findley and Dona Straley for their years of support, Allen Beyerchen for his interest and encouragement, Howard Crane for his gentle guidance and to Kevin Boyle for his pitch perfect advice when I needed it most.

For generous support over many years, I thank the Ohio State University Middle East Studies Center, particularly the director, Alam Payind. The Department of History at the Ohio State University and Richard Hermann of the Mershon Center for International Security Studies have been remarkably generous in their financial support, making possible my research abroad in England and India. My sincere thanks to both. 
Special thanks to James Lenaghan and to my Persian teacher, Farah Shadchehr, for their invaluable friendship. Others at the Ohio State University deserve my sincere thanks: Cynthia Brokaw, Parvaneh Pourshariati, Gail Summerhill, Chris Burton and Jan Thompson. To Joby Abernathy, warm thanks. In appreciation of the friendship and intellectual support which made possible this dissertation: Emre Sencer, Rajiv Khanna, Yiğit and Zulal Akin, Gunhan Börekçi, Safa and Heather Saraçoğlu and Febe Armanios. To the residents of the third floor office, in thanks for the academically-themed illicit potlucks and scalding humor: Christianna Thomas, Jim Weeks, Dustin Walcher, Steve Hyland, John Winters and Rob Padilla.

Special thanks to Scott Levi at the University of Kentucky and Robert McChesney of NYU for their kind support. I am grateful to Jerry Bentley at the Journal of World History for his interest in my work, and to his patient and wonderful editor, Deborah Sasaki, aloha. To my early mentor, Dr. Jon Mandeville of Portland State University, who insistently sent me on this path, and to Pelin Başçi, also of Portland State, thank you. My gratitude to Arif Çetintaş for his enthusiastic support and encouragement. Thank you to Lalita Du Perron at the School of Oriental and African Studies in London and Ayşegul Sönmez of Istanbul. In memory of the late Şinasi Tekin, my beloved teacher of Ottoman Turkish.

Most of all, thank you to my beloved parents, Richard and Jocelyn Fanning, who brought their own fascination with Central Asia to the family dinner table and encouraged their children to travel far and seek knowledge. 
January 14,1958 Born- Detroit, Michigan

1998 Bachelor of Arts, cum laude History/Middle Eastern Studies

Portland State University, Portland, Oregon

2003 Master of Arts History (Islamic/Ottoman Middle East) The Ohio State University, Columbus, Ohio Graduate Teaching Associate, The Ohio State University

\section{PUBLICATIONS}

Research Publication

1. "The Lords of the Auspicious Conjunction: Turco- Mongol Imperial Identity on the Subcontinent," The Journal of World History, Vol. 18, No. 1 (2007) pp. 1- 39.

2. "Jahangir," Encyclopedia Iranica, New York, NY: Columbia University Press, 2006.

\section{FIELDS OF STUDY}

Major Field: History

(South Asia and the Eastern Islamic World; the Ottoman Empire) 


\section{TABLE OF CONTENTS}

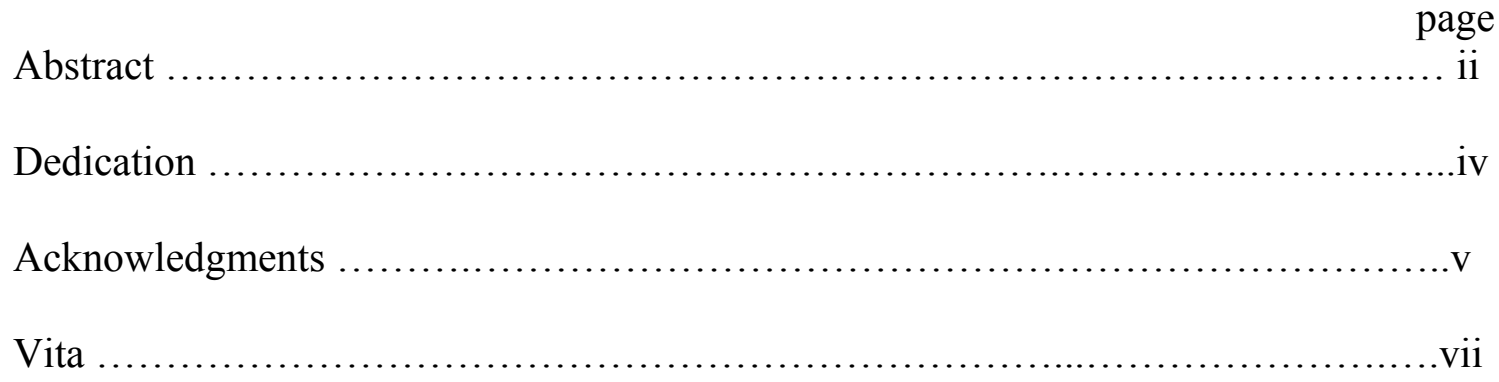

Chapters:

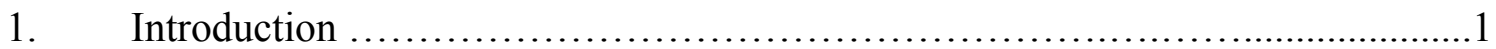

The Timurid- Mughal Mentalité .........................................

Timurid Refugees: "All the Begums and Khanums Went" ................ 7

The Contents of This Study .........................................11

2. The Development and Defense of a Timurid Cultural Identity .................15

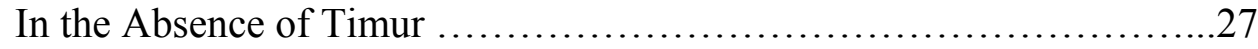

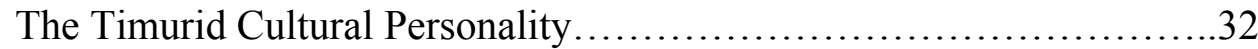

Religious and Literary Patronage ....................................35

Babur's Mawarannahr and the Timurid Denouement ....................45

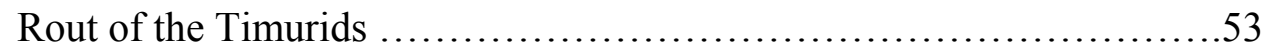

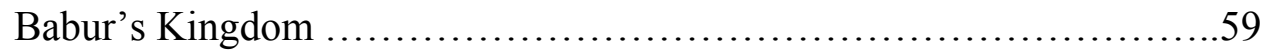

3. Development of the Mughal Imperial Identity .............................72

Genealogy and the Guregeniyya ....................................71

The Mythical Homeland .............................................8 80

The Use of Literature and Art in the Production of Identity in India ......84

Illustration as a Tool in the Imperial Identity Project .....................96

The Imperialism of Architecture and Landscape ....................... 108

Recognition of the Timurid Legacy of the Mughals .....................120 


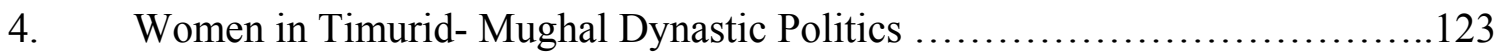

Babur and the Late Timurids ..................................... 127

The Imperial Harem as an Akbari Institution ..........................137

Power, Patronage and Youth .....................................143

Timurid- Mughal Motherhood ...................................149

Marriage and the Mughal Princess .................................154

Non- Timurid Wives of Timurid Rulers ............................156

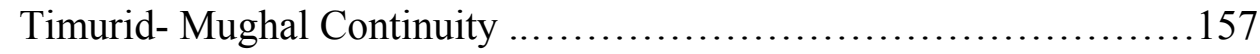

5. Mughal Princes and the Imperial Succession.............................160

Training Princes to Rule: The Imperial Appanage ......................165

Timurid Tanistry and the Mughal Princely Succession ..................174

Humayun and the Failure of Imperial Partition.......................179

Akbar and the Princely Appanage: Timurid Traditions Transformed ...183

Atekes, Naukars, Allies .......................................... 188

Adapted Succession Systems Among Mughal Contemporaries ..........191

Restless Princes, Fratricide, and Timurid Imperial Partition ..............195

Brothers at War .............................................201

How Succession Wars Served the Dynasty ........................208

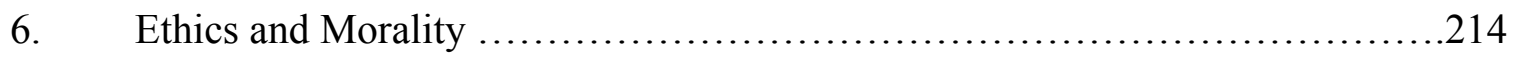

Islamic Identity and the Timurid- Mughal ........................215

Sufi Allegiances: The Naqshbandi, the Chishti and the Royal Cult .....218

The Literature of Ethics and the Mughal Library......................233

Religious Tolerance: The Idiom of Hind is Praiseworthy ................238

A Social Contract: The Shepherd Must Serve the Sheep ...............246

Be a Friend of Wine ...........................................249

Indigenous Literature and the Mughal Translation Movement .............256

The Yasa of Chingis Khan .........................................263

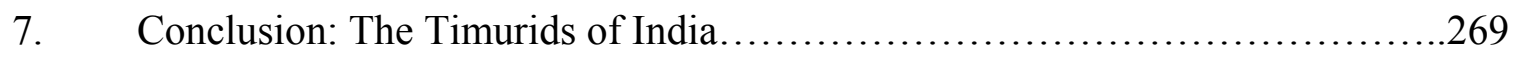

Adaptation and Change: A Mughal Indian Synthesis ..................274

Jahangir: Timurid Prince, King of India............................282

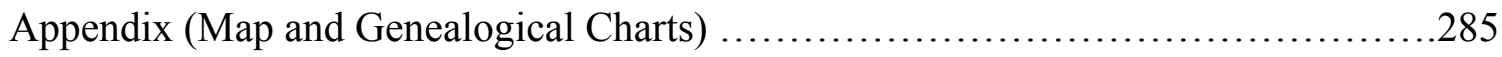

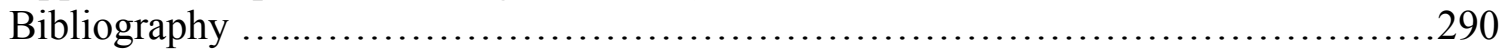




\section{TRANSLITERATION SYSTEM}

There is no standard system of transliteration which can be applied universally and consistently to Turkish, Persian and Sanskrit. For reasons of simplicity and clarity, therefore, I have decided to use, for all languages, a modified version of that employed by the International Journal of Middle East Studies. I have omitted all diacritical marks, although 'ayn and hamza are shown. Place names and personal names with accepted English spellings are spelled in accordance with English norms, unless quoting from another source. As for dating systems, I have chosen again to follow the lead of IJMES, in using only Common Era dating unless quoting from an original source. All translations by the author unless cited. 


\section{CHAPTER 1 \\ INTRODUCTION \\ IDENTITY AND EXILE}

Among the most critical developments in sixteenth-century world history was the emergence of powerful Muslim empires to replace the fragmented tribal alliances and minor sultanates which had remained in the void left by Mongol failure and collapse in the central Islamic lands. These great empires, the Ottoman, Safavid, Uzbek and Mughal, shared Central Asian Turkic political traditions, Persianate aesthetic understandings and a vision of conquest rooted in Mongol aspirations of world empire. Their development of military and political trends, centralized bureaucratic institutions, and vital artistic and cultural expressions would have a powerful lingering global influence.

Contemporary studies of the Mughal dynasty of India have, however, long been dominated by nationalist, sectarian and ideological agendas which typically present the Mughals as a singularly Indian phenomenon, politically and culturally isolated on the subcontinent. Blaming the Mongol invasions of the thirteenth century C.E., which "first propelled Muslim India on its own separate path, distinct from that taken by the lands west of the Indus," modern scholarship on the Middle East and Islamic Central Asia has long marginalized Indian Islam and assigned to the Mughal emperors of the subcontinent a position on the periphery of the early modern Islamic world.

\footnotetext{
${ }^{1}$ Peter Jackson, The Delhi Sultanate, NY: Cambridge University Press, 1999, p. 3.
} 
Although the founder of India's Mughal Empire, Zahir al-Din Muhammad Babur (1483-1530), was a Chaghatay-Turkish prince and a direct descendant of both Chingiz Khan and Timur, few scholars acknowledge that Mughal ties to Transoxiana might have substantial relevance to our understanding of the empire. ${ }^{2}$ Even such an eminent scholar of the Mughals as John Richards, author of the New Cambridge History of India: The Mughal Empire, disregards the Central Asian legacy of the Mughals, declaring that "the interests and future of all concerned were in India." ${ }^{, 3}$ Describing the first two Mughal kings as "immigrants," Richards directly links the dynasty to the preceding nearly thousand years of Muslim colonization in India, describing the Mughals as "indisputably Indian... emerging from the Indian historical experience." ${ }^{4}$ Mughal history for Richards, as for many other scholars, begins with the seventh-century arrival of Umayyad Muslim armies of conquest and the establishment of "Indo- Muslim rulers - whether of foreign or Indian origin" over most of the subcontinent. ${ }^{5}$

Yet to demand one thousand years of Indo- Muslim continuity is to ignore the particular character of the Mughal Empire. The Mughals arrived in India with a set of political, cultural and aesthetic traditions and understandings which were entirely grounded in the late Timurid milieu in Transoxiana from whence they came and they passionately maintained many of these cultural inheritances in India. Scholars of the Timurids, such as Maria Eva Subtelny, have emphasized the "profound influence" of the Timurid legacy on the Mughal dynasty and have questioned the absence of research

\footnotetext{
${ }^{2}$ Valuable work has been done on certain aspects of this legacy: Maria Eva Subtelny has worked on the Mughal retention of Timurid gardens, Richard Foltz has published a study of Mughal links to Central Asia, and Stephen F. Dale has identified the Mughals as the principal heirs of the Timurids.

${ }^{3}$ John Richards, The New Cambridge History of India: The Mughal Empire, New Delhi: Cambridge University Press, 1993, repr. 1995, p.2.
} 
which links them to their ancestry in Central Asia. ${ }^{6}$ Historians of the Mughals such as Muzaffar Alam and Sanjay Subrahmanyam affirm the "traditionally neglected" Central Asian genealogy of the Mughals, calling it "somewhat puzzling why the Mughal specialists have by and large refused, in the past few decades, to place the state they study in the larger context."7

It is time for a radical re-evaluation of the scholarly and intellectual isolation with which the Mughals have traditionally been treated. India's Muslim kingdoms did not, before or after the Mongol invasions, develop apart from the central and hence "normative" Islamic world. More specifically, the Mughal Empire, founded as it was by a Timurid prince from Transoxiana only to become the richest and most populous of all the early modern Islamic empires, cannot be viewed as a uniquely Indian phenomenon. The Mughals must be recognized as the principal inheritors of the Central Asian TurcoPersian legacy of Timur, from whom they were direct descendants: as "true Timurids who enthusiastically embraced Timurid legitimacy and consciously presided over a Timurid renaissance" on the Indian subcontinent. ${ }^{8}$

\section{The Timurid- Mughal Mentalité}

The elaborate and distinctive understanding of cultural identity and legacy that was shared by members of the Timurid refugee elite later shaped their imperial identity in exile where, consciously manipulating their Central Asian legacy, they manufactured a

\footnotetext{
4 Ibid.

5 Ibid., p. 3.

${ }^{6}$ Maria Eva Subtelny, “The Timurid Legacy: A Reaffirmation and a Reassessment," Cahiers D'Asie Centrale, 3-4 (1997), p. 14.

${ }^{7}$ Muzaffar Alam and Sanjay Subrahmanyam, The Mughal State, 1526- 1750, Oxford University Press, 1998 , p. 5.
} 
Mughal imperial identity which would successfully justify, sustain and support their overwhelming imperial success in India. Understanding Mughal efforts to replicate a Timurid mentalité on the Indian subcontinent requires an examination of the process by which the Mughals coordinated and mobilized their cultural personality in the interests of their continued dynastic legitimacy and imperial identity. Identifying intersections and linkages in modern studies of national identity, gently modified to reflect the development of a communal identity which was pre-modern, dynastic and imperial, rather than "national" or "ethnic," can prove useful in explaining and understanding the process by which unifying forces were mustered in order to define and underpin TimuridMughal identity; an identity so successfully constructed as to survive not only transplantation but thrive in a foreign environment well into the modern period. ${ }^{9}$

Therefore, just as ethnic nationalism gains power through a complex of "myths, memories, traditions, and symbols of ethnic heritages... the ways in which a popular living past has been, and can be, rediscovered and reinterpreted... [and] reconstituted in every generation," we can identify similar strategies employed by the Timurid- Mughal construction of imperial identity to confirm the "natural unity" of their social- political community. ${ }^{10}$ Most notably, the Mughals remained devoted to maintaining and

\footnotetext{
${ }^{8}$ Stephen Dale, “The Legacy of the Timurids," Journal of the Royal Asiatic Society, Series 3, 8, 7 (1998), p. 43.

${ }^{9}$ While in his seminal study of ethnic nationalism, Imagined Communities: Reflections on the Origin and Spread of Nationalism. London: Verso Editions, NLB, 1983, Benedict Anderson rejected the notion of premodern cultural community formation, claiming nationalism to be a product of enlightenment, revolutionary thinking and the resultant rise of secularism and literacy in the West, I argue that community identity formation has much earlier antecedents--- as does Nicholas Howe, Migration and Mythmaking in Anglo Saxon England, Notre Dame, Indiana: University of Notre Dame, 2001 and Anthony D. Smith, Myths and Memories of the Nation, Oxford, New York: Oxford University Press, 1999. This study therefore reinforces the arguments of Howe and Smith, that what has previously been identified as the modern framework of ethnic nationalism in fact has a historicity rarely acknowledged, in the medieval and pre- modern development of communal identity.

${ }^{10}$ Anthony D. Smith, Myths and Memories, p. 9.
} 
developing a set of shared Timurid meanings and ideals within the greater social consciousness.

Through a shared obsession with their dynastic legacy, the Timurid refugees in India created symbols, both real and imaginary, which they used to define themselves for over two hundred years. The strength and power of these communal understandings was developed through the creation of a set of "myths," which "bring together in a single potent vision elements of historical fact and legendary elaboration to create an overriding commitment and bond." Although I use the word "myth," the truth or falsity of these stories and symbols is not important, rather the use to which they were put, binding together a social- political community.

In the formation of the Mughal communal identity, the development of a genealogical narrative was built on the identification of a particularly charismatic lineage. Unlike modern nationalist references to a primordial biological link, the TimuridMughals expressed no concern for the purity of their ethnic blood lines and seem instead to have viewed their dynastic lineage, rich as it was in saints and heroes, as so superior as to trump the realities of their regular ethnically mixed marriages. Central to the Mughal sense of unity and belonging are the figures of increasingly mythologized ancestors, represented as hero or deity or a combination of the two. As the descendants of the two greatest empire builders in Central Asian history, Chingiz Khan and Timur, the Mughals' illustrious ancestry supplied them with critical legitimization of their political power both in Central Asia and in India. That they were so well able to transfer the power of their dynastic lineage from their place of origin to the subcontinent, where it

\footnotetext{
${ }^{11}$ Ibid., p. 59.
} 
found support and acceptance not solely across family/dynastic lines but also among elites of other cultures in the far-flung regions to which they came as near strangers, affirms the strength and charisma of the Mughal lineage and the power of the Mughal genealogical narrative.

Territorial considerations were a key component in the unifying Mughal mythology. Not only did the Mughals have an ancestral homeland from which forced migration memories were relatively fresh and bitter but, unlike the majority of populations displaced by war, the Mughals were successful in conquering a new imperial territory. For over two hundred years, the writings of the Mughal emperors expressed longing for the lost ancestral lands and the glittering Timurid capital cities of Harat and Samarqand. In a few cases they acted on their claims of ownership through military intervention. Yet it was not only the lost territories of Mawarannahr ${ }^{12}$ that were mythologized by the refugee- immigrants, whose ownership of various territories was developed in degrees. "Homeland" was an idea applied to territories permanently lost and mourned (Transoxiana, as represented by the city of Samarqand), but also to lands which formed the springboard for success and conquest yet no longer remained the center of their community (Kabul). Finally, a historical justification for the conquest of India was implemented, whereby the utterly foreign subcontinent was reinvented as an integral part of the Timurid- Mughal ancestral legacy. A complex historical narrative of ancestral conquest justified and legitimized their new territorial acquisitions, while the Timurid ancestral homeland was mythologized into a golden country to which the Mughal family ever sought return. 
Timurid refugees: "All the Begims and Khanims Went"

The enormous power of the Timurid legacy in India perhaps needs further explanation; it may not be enough to say that such deliberate retention of the Mughal inheritance was entirely due to its enhancement of political legitimacy in a new geographic context or its power to bind together a diverse group of displaced royals into a unified community. Another factor in the Timurid- Mughal experience which may better explain the passion with which this community clung to an increasingly mythologized cultural memory is that of their often ignored experience as refugees. The Uzbek confederation's conquest of Mawarannahr was absolute; they killed or forced into exile the entire Timurid aristocracy, breaking up their centers of political sovereignty and cultural authority, removing them from established pre- existing sources and symbols of power and legitimacy. Timurid success in exile has led many scholars to view the Timurid- Mughals as a family of royals who simply exchanged one imperial court for another, but their sense of loss should not be minimized: the Timurids who migrated to the subcontinent were a refugee community that had experienced trauma and displacement. That the Uzbek invasion had forced this entire community of former aristocratic elites to flee in search of refuge must be factored into our understanding of the continued power of the Timurid cultural personality.

In contemporary cross-disciplinary studies of refugee and exile identity, the sense of loss and displacement experienced by a community in exile is seen to enable "the

\footnotetext{
${ }^{12}$ Mawarannahr refers to the lands northeast of the Amu Darya river, the same territory that is known in the
} 
growth and development of new identities and subjectivities," creating not only an “unrequited desire for a lost homeland but also a 'homing desire,' a desire to reinvent and rewrite home as much as a desire to come to terms with an exile from it." ${ }^{, 13}$ Refugee populations develop a heightened sense of communal identity, and their sense of loss and displacement combine to accentuate social bonding. Studies of diaspora communities suggest that "collective identities and memories of trauma are deeply intertwined.... Victims of social trauma, and their descendants, often engage in purposeful and explicit remembering, as a form of empowerment and identity formation." ${ }^{\prime 4}$ This surely describes the actions of the Timurid community in India, whose invention of imperial identity on the subcontinent was drawn almost entirely from the communal memories of refugees in exile from their ancestral home.

In the early years of the Timurid displacement Babur managed to maintain a neoTimurid court and refuge in Kabul, although it had remained impoverished and under constant threat of Uzbek invasion. By the time of his conquest of northern India in 1526, Babur's South Asian outpost, on a Kabul- Agra axis, represented the last independent Timurid kingdom. In a remarkable twist in fortune, the desperate Timurid refugees who had been mercilessly driven out of their ancestral lands in Central Asia created a new empire even wealthier and more spacious than the first. A Timurid refugee at Babur's court, in flight from the Uzbek invaders of Transoxiana, wrote, "Babur is now, by the grace of God, seniormost among the progeny of Timur, and it is only becoming that he

\footnotetext{
West as Transoxiana.

${ }^{13}$ Susheila Nasta, Home Truths: Fictions of the South Asian Diaspora in Britain, NY: Palgrave, 2002, p. 7.

${ }^{14}$ Pier M. Larson, "Reconsidering Trauma, Identity and the African Diaspora: Enslavement and Historical Memory in Nineteenth Century Highland Madagascar," William and Mary Quarterly, $3^{\text {rd }}$ Series, Volume LVI, Number 2 (April 1999), p. 335. Italics mine.
} 
should so extend his patronage to all living Timurids, one of whom is the writer himself, that the lamp of the Timurid family may once again shine forth." ${ }^{, 15}$ As the writer had surmised, illuminating the "lamp of the Timurid family" had always been Babur's objective and his dynastic ambition would play out as a compulsion to re-create the Timurid Empire in South Asia. Self- consciously and formally, Babur offered his new kingdom in India, larger and wealthier than the first, as a refuge for members of the Timurid imperial family who had been forced out of their ancestral territories.

Immediately after his successful military conquest Babur called the remaining Timurids of Transoxiana to join his newly established court. His daughter, Gulbadan Begim, described Babur's efforts, writing, "He ordered letters sent to every direction, every quarter, every dominion, that all those attached to us shall receive our patronage, and most particularly those that had given service to our father, grandfather and forefathers.... And those who are of the lineage of Sahib Qiran [Timur] and Chingiz Khan, let them set out for our court. God the most high has conferred upon us the kingdom of Hindustan, so let us see good fortune together."16 Thus, with promises of sanctuary, land and wealth, he lured them south, and in response to Babur's offer of protection and fortune, Central Asian refugees flocked to his Indian court. Within the year, Gulbadan Begim and her foster mother, Maham Begim, had left Kabul for Agra, among the first of Babur's female relatives to arrive. ${ }^{17}$ Within a few years, confirmed

\footnotetext{
${ }^{15}$ Stephen Dale, "The Timurid Renaissance," p. 44.

${ }^{16}$ Gulbadan Begim, Humayunnama (Persian text) or The History of Humayun (trans. and ed. by Annette S. Beveridge; henceforth cited as "Bev."), Delhi: Idarah-i Adabiyat-i Delli, 1972. Translations by the author unless noted. Humayunnama, pp. 13-14.

${ }^{17}$ Humayunnama, p. 15-16.
} 
Gulbadan Begim, "all the begims and khanims went, a total of ninety-six persons, and all were appointed property and a home and furnishings and gifts to their hearts' content." 18

The ninety-six female "stipendiaries," recipients of Mughal imperial largesse, who arrived within those first five years of Timurid-Mughal rule in India were all members of the extended Timurid royal family. The names cited in the sources are the names of the late Timurid Central Asian royalty: Bayqara, Miranshahi, Dughlat, Barlas and more. Yet it must be understood that the migration to Babur's Indian court by so many members of the late Timurid courtly world, a small but significant population movement, was not a matter of chance or choice. Within the next five years a steady flow of desperate women, some fleeing forced Uzbek marriages, accompanied by children and family retainers, arrived at the Timurid- Mughal court to join their male relatives in Agra. They were a refugee population driven out of their homes by the invasion of the Uzbek tribal confederation, which had succeeded in routing local Timurid rulers and destroying Timurid power in Transoxiana to emerge as lords of the old and powerful capital cities of Harat, Tashkent, Bukhara and Samarqand.

Babur was to write, "In this exile my heart has not been gladdened. No one can be comforted at all in exile."19 In Kabul and even more powerfully (because of geographical distance or culture shock?) on the subcontinent, the loss of Timurid Mawarannahr was expressed by Babur's community of refugees as yearning for the ever elusive home, a term which in the case of a refugee community describes not only a geographic space but also an entire complex of common aesthetic understandings, shared

\footnotetext{
${ }^{18}$ Ibid., pp. 13-14.
} 
law, religion and language, shared history (stories of the past; legends), common ancestry, and critically, the final ingredient, a shared sense of enormous loss. This forcible migration became the central, defining event of the Timurid- Mughal community. Geographically and culturally, the refugees developed their loss of home into a shared dynastic memory, which became increasingly idyllic, reconstructed, mythical. It was the combination of terrible loss and displacement, followed shortly afterwards by reunification and relative stability, which conspired to enhance awareness of imperial identity and intensified Timurid- Mughal efforts to affirm ancestral links in culture, ideology and territory.

While there is no doubt that Babur was personally driven by the strong desire to rule over a renewed Timurid court, once in India it was not only Babur who articulated and affirmed a Timurid imperial identity. As representatives of an entire generation of Timurid elites--- a generation nearly lost to the invading Uzbeks--- this band of refugees successfully developed an elite ruling émigré community in northern India. Their community identity was based on the political charisma of the paramount ancienne Timurid royal family. As refugees they clung compulsively to their Central Asian identity, traditions and ideologies, carefully replicating the relationships and customs of their ancestors and passing down to their descendants their own obsessions with the dynastic past.

\footnotetext{
${ }^{19}$ Zahir al-Din Muhammad Babur, Baburnama (Vekayi), Eiji Mano, ed., Chaghatay text, 3 vols., Kyoto: Syokado, 1995. Translations by the author unless noted. Baburnama, W. Thackston, trans. and ed., Chaghatay, Persian and English texts, 3 vols., Harvard University, 1993. Thackston tr., p. 200.
} 


\section{The content of this study}

In this study of the displacement and migration of a particularly powerful imperial identity, the focus of chapter two is on the painstaking effort to manufacture a Timurid cultural personality in Central Asia: first by the empire-builder Timur and later by his fractious successors in their rival princely courts. The results of this effort endowed the Timurid dynasty with imperial grandeur and legitimacy within their conquest territories and well beyond. Developed over generations into an entire cultural complex, the Timurid identity represented such political charisma that it became in many ways the model for contemporaries across the Muslim world. Chapter three explores the methods by which the Timurid refugees were able to transfer this imperial dynastic identity to the subcontinent through the act of "purposeful and explicit remembering." Relying on shared genealogical and territorial historical narratives and commonly accepted bonds of culture and ideology, the Mughals affirmed their potential for group identity and collective action through the careful cultivation of the Timurid identity on the subcontinent.

The remaining four chapters of this study will explore the various culturalideological components of the Mughal narrative. Expressed in shared values and artistic sensibilities, language, institutions of religion and ethics, Mughal understandings of culture and morality were carefully linked backwards, affirming continuity through sacral ties to ancestral virtues and values. Certainly, in the case of the Mughals, who, as we have already affirmed, did not require ethnic homogeneity, this shared "cultural personality" necessarily served to connect the dynasty with the enormous population of followers, courtiers, retinues and members of the various imperial courts who were 
completely unrelated to the Mughal lineage and its declared Turkish ethnicity. ${ }^{20}$ Mughal eclecticism and relative tolerance were responsible for a remarkably diverse royal court, and their understanding and acknowledgement of the unifying power of shared values, language and cultural understandings were the tie that bound these populations in loyalty to the emperor. It is within this context that we can discuss the inheritance of traditional models of behavior within the Timurid-Mughal family, Chapter Four will discuss the influence of Timurid tradition in the women's harem of the Mughals and Chapter Five the education of princes and the always contentious imperial succession. Chapter Six examines a very specific body of religious and secular literature that served as the basis of Timurid ethical development. Carried to India by the Timurid exiles, it developed into an immutable Mughal literary canon, the presence of which may explain the highly resistant Timurid character of Mughal political and cultural ethics.

In Chapter Seven, the conclusion, we will explore those aspects of Mughal culture which represent, in contrast to all that has been previously discussed, Mughal South Asian synthesis and inclusion. Almost immediately after fleeing Central Asia, the Mughal imperium began to include non- Timurid components in the form of imperial military and administrative elites, courtiers and royal wives. Their own inclusiveness had a powerful impact on the Mughal consciousness, although the impact was markedly more cultural than political or religious. For example, in the imperial workshops, architects, musicians and painters explored the artistic traditions not only of the Timurids and Persians, but also indigenous Indian and European forms, ultimately producing an entirely original expression of imperial aesthetics. Even on occasions when Timurid

\footnotetext{
${ }^{20}$ For the use and development of the term "cultural personality," see Stephen F. Dale, Garden of the Eight
} 
traditions were not immediately affected by the cultural synthesis, an often surprising unity of understanding between Timurid and ancient Hindu ideas of kingship and empire occurred which reinforced Mughal imperial pretensions on the subcontinent. It is clear that while their imperial writings privilege the Timurid past over the Indian present, the Mughal dynasty did in some aspects develop a culture of inclusion and adaptation.

In Kabul, and later in the relative wealth and safety of Agra and Delhi, the community of refugees who had suffered displacement and abuse were reunited, enriched and emboldened, forming what they publicly proclaimed to be a new Timurid imperial court. The ancestral lands of Mawarannahr had been lost to them forever, but the Timurid political and social culture, carefully constructed over generations to define and defend Timurid identity and legitimacy, would be meticulously maintained in the royal courts of the neo-Timurid emperors of the subcontinent, the Mughal dynasts of India.

Paradises, Leiden: Brill, 2004, chapter 3. 


\section{CHAPTER 2}

\section{THE DEVELOPMENT AND DEFENSE OF TIMURID IMPERIAL IDENTITY}

Since events in this world are intertwined and interwoven with each other, in order to ascertain the beginnings of the Sahib Qiran's career it is necessary to introduce several narrations, and there the beginning will be made. ${ }^{21}$

The Mongol invasions, led by Chingiz Khan (r. 1206- 27) in the first half of the thirteenth century, had succeeded in creating the largest land- based empire in history, stretching from China to the Mediterranean. ${ }^{22}$ Through personal charisma and superb military leadership, Chingiz Khan had altered and subordinated traditional loyalties, forming an army of perhaps seven to eight hundred thousand men organized on a decimal- based system of units from ten to ten thousand, rather than the traditional tribal groupings of the Turco-Mongol warlords. ${ }^{23}$ Political legitimacy for Chingiz Khan included the conviction that "God had designated him [Chingiz Khan] the sole legitimate ruler of the world, and that he had transmitted sovereignty to his descendants." 24

\footnotetext{
${ }^{21}$ Sharafuddin Ali Yazdi, "Zafarnama," in A Century of Princes: Sources on Timurid History and Art (hereafter cited as CP), Wheeler Thackston, tr. and ed., Cambridge, Massachusetts: The Aga Khan Program for Islamic Architecture 1989, p. 65.

${ }^{22}$ No region was as thoroughly destroyed in the Mongol onslaught as Transoxiana, and Khurasan was "comprehensively wrecked by Chingiz Khan's youngest son, Tolui." See David Morgan, The Mongols, Cambridge, Massachusetts: Blackwell Publishers, 1986, reprint 1994, p. 41.

${ }^{23}$ For a description of Chingiz Khan's distribution of tribes, see Paul Kahn, A Secret History of the Mongols: an Adaptation of the Yuan Cha'o Pi Shih, translated by Francis Woodman Cleaves, Boston: Cheng \& Tsui Company, 1984, 1998, pp. 114- 145. See also David Morgan, The Mongols, pp. 89- 90. ${ }^{24}$ Douglas E. Streusand, The Formation of the Mughal Empire, Delhi: Oxford University Press, 1989, p. 29.
} 
Under Mongol successor khans major cities were rebuilt, commerce and agriculture were re-established and scholarly and artistic enterprises were again encouraged. The religious tolerance of the Mongols, marked "not so much by highmindedness as by indifference, ${ }^{25}$ led to the gradual adoption of regional religions; by the 1280 's, the Ilkhanid Mongols of western Asia had begun converting to Islam. Persianate urban culture became hegemonic at the increasingly cultured Mongol successor courts, which oversaw the construction of mosques and madrasas, the production of literary manuscripts and miniature paintings, and the patronage of scientists, astronomers, poets and historians. ${ }^{26}$ Each of the newly conquered Mongol territories had been carefully manned with troops and representative administrators from each of the four uluses, ${ }^{27}$ so that even when political and administrative cohesion were gradually lost, Mongol conquest territories retained a measure of unity. ${ }^{28}$ Population exchanges, shifting frontiers and the steady migration of tribes, rival princes, scholars and artists established and affirmed a degree of shared culture and common history. ${ }^{29}$

The lingering charisma of Chingiz Khan was powerful enough to unite the successor khanates for forty years after his death, but eventually fraternal rivalry fragmented the empire. Although the years following his death saw the gradual breakup of the Mongol Empire into a series of smaller successor states, political legitimacy in

\footnotetext{
${ }^{25}$ Morgan, Mongols, p. 41.

${ }^{26}$ Thomas W. Lentz and Glenn D. Lowry, Timur and the Princely Vision: Persian Art and Culture in the Fifteenth Century, Los Angeles and Washington, D.C.: Los Angeles County Museum of Art and the Arthur Sackler Gallery, Smithsonian Institution, 1989, p. 24. Among these scientists was Nasir al- Din Tusi (1201-1274), whose political philosophy had a formative influence on the fifteenth-century Timurids of Central Asia, as it would later on the Mughals and Ottomans.

${ }^{27}$ The ulus was a territorial unit (appanage), described as a tribe, community, "nation." See Dale, Garden, p. 111. For specific usages in the Mongol/Timurid/Mughal context, see footnote 30, this chapter and chapter five.

${ }^{28}$ Beatrice Manz, The Rise and Rule of Tamerlane, NY: Cambridge University Press, 1999, p. 4.
} 
Central Asia had become entirely tied to the contender's possession of the charismatic lineage of Chingiz Khan. The absolute consolidation of power under Chingiz Khan and his immediate successors, and the cultural and scholarly achievements attained under Mongol patronage, particularly that of the Ilkhanid Mongol successor state incorporating much of the Islamic world, firmly established the Chingizid dynastic line as the most potent force in Central Asian politics. Rulership in the region was and would continue to be regularly and violently contested, but the only candidates for power were recognized princes of Chingizid lineage and no effort was made to set up an alternative ruling house. $\operatorname{Timur}^{30}(1336-1405$, r. 1370-1405), a petty tribal ruler of the Turkic Barlas clan, one of the groups making up the Chaghatay ulus, ${ }^{31}$ spent decades developing and consolidating his own power in Central Asia. ${ }^{32}$ Although Timur had the good fortune to rise to power at a time when the Chaghatayid descendants of Chingiz Khan had lost effective power in the region of Transoxiana, local understandings of political legitimacy and power required that a claimant to power attach himself to the glory and success of the Chingizid line. In developing and protecting his political viability, much of Timur's

\footnotetext{
${ }^{29}$ Beatrice Manz, "Mongol History rewritten and re-lived," REMMM 89- 90. pp 129- 149, 2002. p.136.

${ }^{30}$ Timur is better known in the West as Tamerlane, which is itself a mistaken convolution of the Persian name which was given to him after an early accident lamed him in one arm and leg: Timur-i Leng, or Timur the Lame.

${ }^{31}$ The Chaghatay ulus, so-called because it was the inheritance of Genghis Khan's second son Chaghatay, was originally made up of those Central Asian regions later known as Transoxiana in the west and Mughulistan in the east. The split into two parts occurred gradually during the fourteenth century. A fuller description of this territory is included below, in the discussion of the region at the time of Timur's death.

${ }^{32}$ The peoples of twelfth century Mongolia had become so intermarried with Turkic tribes that to distinguish one from another is impossible on any basis beyond that of the language spoken by a particular group. See Morgan, Mongols, p. 56. Some consider the Barlas to have been a Turkicized (Turkishspeaking) Mongol clan, rather than of pure Turkish origin. Timur himself claimed to share an ancestor with Chingiz Khan, and fifteenth century Timurid histories state that the Barlas tribe had been assigned as a military adjunct to the Chaghatay retinue prior to the death of Chingiz Khan in 1227. See Lentz and Lowry, p. 27. His descendants, however, emphasizing Timurid genealogy over Chingizid, were careful to refer to themselves as Turks.
} 
success lay in his ability to meticulously evoke Chingizid symbols and images in order to establish his claim to legitimate rule over former Mongol territories.

As a member of the Barlas tribe, Timur could be counted among the tribal aristocracy, but in assertions of political legitimacy he was unable to lay claim to a Chingizid lineage. Recognizing the power of the royal lineage, employing "formal strategies of official modesty," Timur did not attempt to ignore or circumvent regional requirements for rule. ${ }^{33}$ Instead, in recompense for his own genealogical shortcomings, from the time when he took power in 1370 he did not attempt to claim the imperial title khan, the mark of sovereignty among the Turco- Mongol tribes, but instead enthroned a Chaghatayid puppet khan, through whom he ruled as amir, commander. To confirm his status, he married into the charismatic Chingizid line, taking Saray Malik Khanim, the daughter of the Chaghatayid Khan Qazan, as wife, from which point he effectively wielded the title of Guregen, son- in- law. As ruler, in fact if not in name, Timur married off his sons, Umar Shaykh (d. 1394), Miranshah (d. 1408) and Shahrukh (1377- 1447), and grandsons Muhammad Sultan (1375- 1403) and Ulugh Beg (1394- 1449), to women of the Chingizid lineage, merging the two dynastic lines. Throughout his reign, even at the height of his powers, Timur continued to use amir and Guregen as his official titles on coinage and official correspondence. In addition, he began to use a pre- Islamic Persian title with supernatural and universalist implications, Sahib Qiran, Lord of the Auspicious Conjunction.

Timur was highly sensitive to the potency of Chingizid references and symbols. It has been suggested that even Timur's extreme and systematic use of violence was part of

\footnotetext{
${ }^{33}$ Beatrice Forbes Manz, "Tamerlane's Career and Its Uses," Journal of World History, 13.1 (2002), p. 3.
} 
a conscious effort to evoke the legacy of Chingiz Khan. According to Beatrice Manz, who accuses Timur of theatricality in pursuit of political legitimacy, Timur's early campaigns had been markedly less fierce than his latter. ${ }^{34}$ Equally, the Timurid armies were not naïve nomad forces but were well acquainted with the urban and sedentary society they were, in many cases, destroying. ${ }^{35}$ Even Timur's ruthless violence, then, may have been a carefully orchestrated and easily recognizable evocation of Chingizid power and legitimacy, manipulated and interpreted for an increasingly awed public audience, not only local but international. As a further assertion of Mongol imperial ideology, Timur claimed possession of a heavenly mandate, proven by his stunning military success, itself an easily recognizable echo of Chingiz Khan's power and an affirmation of his own equally spectacular success.

However, conditions in Central Asia had altered. In the thirteenth century Chingiz Khan had been able to wrench political legitimacy out of a combination of personal charisma, brute power and the careful manipulation of Turco-Mongol ruling custom. His overwhelming success, and the careful nurturing of his legacy by his immediate successors, had led to a near- sacralization of the Chingizid line. But by the fourteenth century there existed yet another critical source of legitimation among the Turco-Mongol tribes of Transoxiana-- Islam, filtered and interpreted through the urban Persianate tradition. Although military success and the wealth which resulted from brigandage and demands of tribute might have been sufficient to sustain a Turco- Mongol warlord, as the ruler of the Mongol conquest lands of Central Asia it was necessary for

\footnotetext{
${ }^{34}$ Ibid., p. 1.

${ }^{35}$ Idem., "Mongol History," p. 138.
} 
Timur to meld the region's two seemingly contradictory but equally powerful sources of legitimation: Turco-Mongol Chingizid custom and the Perso-Islamic tradition.

Himself a Muslim, as was most of the sedentary population he conquered, Timur was careful to affirm his Islamic identity within his constructions of legitimacy and right to rule. He did not hesitate to declare himself the champion of Islam, a strategy which succeeded, in part, because the majority of his followers, while retaining loyalty to Chingizid tradition, had long since converted to Islam and did not concern themselves with any ideological conflict between Mongol yasa and Islamic shari 'a. Timur commissioned a number of mosques and madrasas, and offered patronage to the Yasavi order of Sufis, among other mystical orders. He is particularly noted for the construction of a monumental building at the shrine of the twelfth-century shaykh Ahmed Yasavi at Yasi, north of Tashkent, which contains an enormous bronze basin and a set of six oil lamps carrying an Arabic inscription establishing the piety of their patron, "The most glorious Amir, the master of the necks of nations, the one under the special care of the King, Amir Timur Guregen, may he be exalted...."36 Timur also built the tomb of the powerful Naqshbandi leader Khwaja Ata and regularly visited the shrine. ${ }^{37}$ Memoirs attributed to Timur, most probably fallacious productions of a later period, claim that his stunning military success had been predicted by the fourteenth- century Naqshbandi sheikh Amir Kulal, who is said to have declared, "The sovereignty of the territories of

\footnotetext{
${ }^{36}$ Lentz and Lowry, p. 29.

${ }^{37}$ Yazdi, Zafarnama, (Bib. Indica), II, p. 9-10, quoted in Khaliq Ahamad Nizami, State and Culture in Medieval India, New Delhi: Adam Publishers and Distributors, 1985, p. 161.
} 
God has been bestowed on this young Turk." ${ }^{38}$ In exchange for his financial support of individual Sufi leaders and their tariqats (lodges), Timur was the recipient of their public support, which enhanced his religious prestige and affirmed his legitimacy as an Islamic king in the eyes of a public loyal to the popular religious orders.

In illustration of the great Timurid compromise, Timur's marriage to Tukal Khanim, daughter of Khizr Khwaja Oghlan, was celebrated in both Muslim and Mongol traditions. In addition to establishing the Islamic nature of the event, affirming the marriage in the presence of qadis and members of the ulama, as well as referencing Mongol tradition through the exchange of horses, our chronicler was compelled to additionally evoke other publicly recognizable markers of legitimacy and power, in the imperial imagery which would resonate in early modern West Asia. ${ }^{39}$ As the bride approached, the men of Timur's retinue set out to greet her. "They went for fifteen days and performed the rituals of nithar [the ceremony of coins and jewels sprinkled over the heads of bride and groom] and the presentation of horses.... All along the way elaborate toys [feasts] were held at every yurt and on Wednesday the first of Rabi 800 [November $22,1397]$ the $N u s h u b a^{40}$ of the age was ushered with all ceremony into the worldreceiving court of the Alexander of his time... The qadis [judges] and ulama [religious scholars] were summoned. ${ }^{41}$

\footnotetext{
${ }^{38}$ Tuzukat-i Timuri, ed. Major Davey, Oxford, 1783, p. 32, as quoted in Hamid Algar, "Political Aspects of Naqshbandi History," Naqshbandis: Cheminements et situation actuelle d'un ordre mystique musulman, Actes de la Table Ronde de Sèvres, ed. Marc Gaborieau, et al., Editions Isis: Istanbul, 1985, 1990, p.124.

${ }^{39}$ While references to "the Alexander of his Age," would have been a common trope for rulers in the Islamic world, only in post- Ilkhanid Central Asia would they have been so neatly coupled with allusions to pre- Islamic Turco- Mongol tradition.

${ }^{40}$ Nushuba (also nushaba: the water of life) was the name of a famed queen of ancient Barda in Azerbeijan.

${ }^{41}$ Sharafuddin Ali Yazdi, "Zafarnama," in Thackston, CP, p. 87.
} 
Although there were those who objected, ${ }^{42}$ a general comfort with the coexistence of the two law codes meant that not only did Turco-Mongols identify as Muslims but even the Persian viziers of the Timurid princes at times found it useful to reference Chingizid law, the yasa. ${ }^{43}$ According to a contemporary biographer of Timur, although many of his soldiers were Muslim, the Timurid armies remained of mixed religious loyalty, making Timur's balancing act all the more critical. "He had in his army Turks that worshipped idols and men who worshipped fire, Persian magi, soothsayers and wicked enchanters and unbelievers. ${ }^{\text {44 }}$ Timur's success lay in his ability to suggest and presume the viability of compromise between very different legitimizing traditions, developing them into a workable ideological fusion. Proclaiming himself a pious Muslim and defender of the faith, associating with sayyids [descendants of the prophet Muhammad] and respected members of the ulama, while remaining respectful and attentive to the legacy and tradition of Chingiz Khan, Timur established a new and very powerful model of legitimation in Perso-Islamic/ Turco-Mongol Central Asia which would sustain his descendants for well over a hundred years. ${ }^{45}$

Anxious to demonstrate his power, add to his glory, and establish his right to rule, Timur was personally involved in the carefully managed fabrication of his own public image. Following in the Persianate courtly tradition and that of the later Mongol Ilkhanates, Timur made a political statement from literary, artistic and architectural patronage. As the Ilkhanids had done, Timur seems likely to have established a

\footnotetext{
${ }^{42}$ His captive Arab biographer Ibn Arabshah, accused Timur of preferring Chingizid law over that of Islam, and claimed "he must be accounted an infidel." Ahmed Ibn Arabshah, Tamerlane or Timur, the Great Amir, J.D. Sanders, tr., Lahore: Progressive Books, 1976, p. 299.

${ }^{43}$ Manz, "Mongol History," p. 142.

${ }^{44}$ Ibn Arabshah, Tamerlane, p. 321.
} 
kitabkhana in Samarqand, for the production of illustrated manuscripts. ${ }^{46}$ Although he was illiterate, Timur not only spoke Chaghatay Turkish, his native language, but also Persian, the lingua franca of medieval Central Asia. Contemporary writings confirm Timur's awareness of and interest in the vast array of Persian literature in what was a highly literate milieu. "He was constant in reading the annals and histories of the prophets of blessed memory and the exploits of kings and accounts of all those things which had formerly happened to men at home and abroad., ${ }^{, 47}$

His desire to construct a legacy of his own choice and making is evident in Timur's involvement in the production of histories of his own reign. The Chingizid courts had not previously developed a tradition of narrative court historiography, although their later incarnation, the Ilkhanids, in contrast, had produced the famed Persian-language histories of Juwayni (d. 1283/ 681), Rashid al- Din (d.1318- 718) and Vassaf (fl. ca. 1328/ 681), which by default remain our only sources for the first century of Chaghatay rule. In the political fragmentation that followed the death of the Ilkhanid ruler Abu Sa id Bahadur Khan in 1335, Ilkhanid history writing disappeared, ultimately to be revived by Timur, who "provided the stimulus for this development both through his general interest in history, geography and genealogy, as well as his specific desire to have his activities and achievements accurately recorded. ${ }^{48}$ Every detail of his court chronicles, most of which were composed at his instigation, was checked and cross-

\footnotetext{
${ }^{45}$ Ibid., p. 298, for a discussion of Timur's choice of companions.

${ }^{46}$ No evidence of a Timur-era kitabkhana in Samarqand exists, although his interest in the capture of artists of the book (calligraphers, literary scholars, miniaturists and book binders) suggests that manuscript production was occurring in his capital city. His successors, beginning immediately with Shahrukh, are known to have established kitabkhanas in the major cities of Mawarannahr and Khurasan.

${ }^{47}$ Ibn Arabshah, Tamerlane, p. 299

${ }^{48}$ John E. Woods, "The Rise of Timurid Historiography," Journal of Near Eastern Studies, 46, No 2 (April 1987) pp. $81-108$, p. 82.
} 
checked in his presence and eventually edited by Timur himself. ${ }^{49}$ A "sharp proliferation" of histories in the fourteenth century included chronicles in Persian produced or begun during Timur's lifetime, including Jush-i khurush (The Raging and Roaring) by Shaykh Mahmud Zangi Ajami Kirmani and its Zayl (Continuation) by his son Qutb al-Din; Futuhat-i Miranshahi (The Conquests of Miranshah) of Sa'id Allah Kirmani; Ruznama-i futuhat-i Hindustan (Journal of Indian Conquests) of Qazi Nasir alDin Umar; and the Zafarnama (Book of Conquests) of Nizam al-Din Ali Shami, written in 1404. Early Timurid-era chronicles composed in Chaghatay Turkish included the Tarikh-i khani (Khanid History) and Zafarnama (Book of Conquests) of Safi al-Din Khuttalani Samarqandi. ${ }^{50}$ Of these works none is extant, although fifteenth-century copies of the Zafarnama of Nizam al-Din Ali Shami do exist. This is considered to have been the most important of the Timurid histories, commissioned personally by Timur and intended to be a work "free from rhetorical artifice" and "preciosity." ${ }^{51}$ It was finished in 1404 and served as the basis of other surviving histories of Timur, including the Zafarnama of Sharaf al-Din Ali Yazdi, completed in 1425 for Ibrahim Sultan ibn Shahrukh, then governor of Shiraz. The popularity and influence of these works was enormous; Yazdi's Zafarnama was copied and illustrated no fewer than thirty times in the years between 1425 and $1507 .{ }^{52}$

Timur, like Chingiz Khan before him, robbed the conquered cities of his empire of their artisans and craftspeople, shipping them off as slaves through whose labors he might glorify the capital city of his Timurid empire, Samarqand. There, Timur

\footnotetext{
${ }^{49}$ Sharafuddin Ali Yazdi, Zafarnama, in Thackston, CP, p. 65.

${ }^{50}$ Woods, "Rise of Timurid Historiography," pp. 82- 85. See also Lentz and Lowry, p. 52.

${ }^{51}$ Ibid.
} 
articulated his vision of kingship and imperial identity-- a Timurid glorification supported by a merger of Chingizid and Perso- Islamic imperial understandings-- through the construction of vast and splendid ceremonial spaces. It is significant that Timur, who had begun his career as little more than a semi-nomadic brigand, chose to showcase his wealth and might through the extravagant development of an urban center, representing the sophisticated Persianate urban world he had so successfully conquered. In Samarqand, ringed by a series of suburbs named for the great cities conquered by Timur (including Damascus, Delhi and Tabriz) imperial aggrandizement was expressed architecturally, as massive domed structures were raised in Timur's honor.

Perhaps reflecting his nouveau arrivé tastes, the structures he commissioned were massive in scale; when the madrasa being built by his chief wife began to loom over the mosque Timur was constructing exactly opposite, he had his architect killed and the mosque enlarged to throw the madrasa into shadow. ${ }^{53}$ The mosque, which he had begun in 1399, was said to have had a Quranic verse inscribed on the portal in letters so large that they could be read from two miles away. ${ }^{54}$ "No head was raised above him but he brought it low and no back was stronger than his but he broke it and he was thus in all things which concerned and touched him. ${ }^{, 55}$ The degree of his personal interest in these grandiose displays of his own might and power was so great that even when he was too

\footnotetext{
${ }^{52}$ Thackston, CP, p. 63.

${ }^{53}$ Ibn Arabshah, Tamerlane, pp. 222-3.

${ }^{54}$ Zahir al-Din Muhammad Babur, Baburnama, trans. Beveridge, London: Luzac \& Co., 1971, p. 77. See also Lentz and Lowry, p. 36.

${ }^{55}$ Ibn Arabshah, Tamerlane, p. 223.
} 
weak and old to stand, Timur was carried in every morning on a litter to oversee the construction of his monument. ${ }^{56}$

Gardens were designed to surround the palaces of Timur's capital city with acres of meadows, fruit trees and floral and vegetable plantings through which artificial streams ran and wild deer roamed. Formal gardens of this design had originally been developed in pre-Islamic Iran to serve as private retreats for earlier Persian rulers, but for Timur they became the center of public display and court ritual. Awed observers describe seeing Samarqand's thirty imperial gardens filled with luxurious tents of brocade and silk, dazzlingly decorated with gemstones, gold and feathers, and "roofs of silver and stairs to ascend and ...couches, on which they might recline.... They also showed rare treasures and hung there curtains of rare marvelous beauty. ${ }^{, 57}$

As Ibn Arabshah notes, this opulent presentation included overt symbols of political power: the booty from Timur's imperial conquests. In this case Timur's invited guests from across the globe were shown a marvelous cloth from the treasures of the Ottoman sultan, Bayezid Yildirim, one of Timur's chief rivals. His defeat carried enormous weight in the Islamic world, and not incidentally greatly impressed the European powers, who had been themselves threatened by Bayezid the Thunderbolt's expansionist military successes. Ibn Arabshah writes:

Among them [the treasures] hung a curtain of cloth taken from the treasury of Sultan Abu Yazid [Bayezid] of which each part was about ten cubits of the new measure in breadth, decorated with various pictures of herbs, buildings, and leaves, also of reptiles and with figures of birds, wild beasts and forms of old men, young men, women and children and painted inscriptions and rarities of distant countries and joyous instruments of music and rare animals exactly

\footnotetext{
${ }^{56}$ Ruy Gonzales de Clavijo, Embassy to Tamerlane, 1403- 1406, Guy le Strange, tr., New York and London: Harper and Brothers, 1928, p. 280. See also Lentz and Lowry, p. 36.

${ }^{57}$ Ibn Arabshah, Tamerlane, p. 216.
} 
portrayed with different hues, of perfect beauty with limbs firmly jointed: with their mobile faces they seemed to hold secret converse with you and the fruit seemed to approach as though bending to be plucked. This curtain was one of the wonders of the world, yet its fame is naught to the sight of it. ${ }^{58}$

Timur was inviting his guests to view not only beautiful gardens and displays of luxury and wealth, but also tangible reminders of Timurid military invincibility, such as this striking evidence of his successful campaign in Anatolia. ${ }^{59}$ In this way, the elaborate gardens of Samarqand, their fragile and transitory nature notwithstanding-- and certainly none has survived to the present-- as much as any monumental structure of stone or marble played a carefully constructed role in the theatre of Timurid pageantry and courtly ceremony. ${ }^{60}$

\section{In the Absence of Timur}

Carefully constructing the same kind of supra-tribal alliances established by Chingiz Khan, Timur had been able to destroy his rival, the Mongol ruler Amir Husayn, and conquer Iran in a series of military campaigns from 1386 to 1388, from 1392 to 1396 and in 1399. ${ }^{61}$ Between 1398 and 1399 Timur led his armies into northern India, ruled by the Delhi sultans, where they sacked the ancient capital of Delhi. In 1400 Timur swept into the territory of the Mamluk sultanate, taking Aleppo, Hama, Baalbek and Damascus. Circling north, Timur then marched into Anatolia, where, as we have already seen, he defeated the Ottoman sultan Bayezid I at the Battle of Ankara on July 28, 1402. When he

\footnotetext{
58 Ibid.

${ }^{59}$ The Ottoman Sultan Bayezid I was defeated by Timur at the Battle of Ankara in 1402. See below the comments by the political commentator Mustafa Ali for an Ottoman interpretation of the contest between the two great kings.

${ }^{60}$ Clavijo, Embassy, p. 238 and Ibn Arabshah, Tamerlane, p. 216. See also Lentz and Lowry, p. 34.
} 
died in 1405 Timur was proceeding with a long- planned march on China, the success of which would have completed his conquest of the entire Mongol imperial territories.

Timur had not attempted to impose his own administration within these far-flung territories. While claiming pre-eminence over them, he directly governed only Iran and Central Asia, which supplied him with a comfortable tax base and manpower for his armies of conquest. In classic Turco-Mongol tradition, Timur distributed his conquest territories as appanages among his male descendants, who served as extensions of the central government, ruling provinces and leading armies at the behest of their father. After his death, in the absence of his dominating presence, however, there was immediate fragmentation, for the political autonomy of the princes had depended on the charismatic power held by the sovereign. His death left a terrifying void. Timur's chosen successor, a grandson, Pir Mohammad ibn Jahangir, was unable to impose control over rival brothers and cousins, for in the absence of clear authority the princes each pursued personal ambitions. In 1409, after five years of interfamilial war, Timur's third son, Shahrukh, the governor of Khurasan, declared victory and emerged as the heir to his father's empire. Forty years of relative stability followed, as Shahrukh ruled in Harat while his eldest son, Ulugh Beg, served as his deputy in Samarqand.

With Timur dead, his successors were forced to reinvent the Timurid public image and political identity, this time in order to defend a dynastic, rather than personal, legitimation. ${ }^{62}$ Timur had so successfully melded the contradictions implicit in fourteenth-century Central Asian political legitimation that his descendants had no need to pursue the same goal; from this point forward, the Timurid successor courts would

${ }^{61}$ Beatrice Forbes Manz, The Rise and Rule of Tamerlane, New York: Cambridge University Press, 1999. 
defend and define their rulership through the personality of Timur himself. It was no longer necessary to govern behind a Chingizid puppet khan, and as for Timur's deliberately unpretentious appellation "Guregen," over the years this title became a powerful and positive evocation of the hero- ancestor, Amir Timur, and no longer a mark of humility and apology for non- Chingizid rule. ${ }^{63}$

Just as Timur had modeled his display of imperial identity and legitimacy in Mongol conquest territories on that previously established by Chingiz Khan, Timur's descendants developed and molded Timur's identity to define and support their viability as individuals within the dynasty of Timur and within Timurid conquest territories. In the interests of maintaining their right to rule, through the manipulation of Timurid historiography and the development of a "cult of artistic patronage," Timur's successors artfully developed and codified Timur's imperial identity and therefore that of the entire dynastic line ${ }^{64}$ From this time forward it would be Timur's lineage, as much as that of Chingiz Khan, which would serve to establish and confirm political legitimacy in Central Asia.

Various interpretations of the Timurid identity were developed to fill the needs of the individual rivals for power. As Timur's successor, Shahrukh deliberately chose to model his reign on that of the Islamicized Ilkhanate, in particular its first Muslim ruler, Ghazan Khan, as a way of confirming a paramount Islamic identity while continuing to appeal to the Timurid dual loyalties of Islam and Mongol tradition without obvious

${ }^{62}$ Beatrice Manz, “Tamerlane's Career and Its Uses,” Journal of World History, 13.1 (2002), p. 6.

${ }^{63}$ As we shall see, "Guregen" became so powerful an evocation of Timur and the political legitimacy that his lineage conferred that the Mughal Empire of India chose "Guregeniyya" (the people of the son-in-law) as their formal dynastic title, to affirm their charismatic genealogy.

${ }^{64}$ Lentz and Lowry, p. 74. 
contradiction. Emphasizing far more vehemently than had his father the dynasty's allegiance to Islam, Shahrukh referred to the "caliphate" on his coinage, regularly called for the shari' $a$ to replace the yasa, ordered the destruction of wine shops and publicly poured the wine into the streets, offered a new kiswa (cover) for the Ka'ba, and generally presented himself as "the restorer of Islamic order." ${ }^{, 65}$ Significantly, Shahrukh rejected Timur's title Guregen, replacing it with Padshah-i Islam. ${ }^{66}$ Yet Shahrukh continued supporting the Turco- Mongol tradition. While publicly promoting the shari'a he punished those who infringed against the Chingizid yasa, continued to impose traditional Mongol taxes (although naming them for sanctioned Islamic taxes) and retained a Chingizid court, the yarghu. ${ }^{67}$

This balance was maintained by his son, Ulugh Beg (1394- 1449), who as ruler reverted to the use of his grandfather's title, Guregen, and publicly emphasized his Chingizid roots, while at the same time he was reputed to have memorized the Quran in all seven of its variant readings. ${ }^{68}$ The contradictions within the Timurid identity were constantly renegotiated at Ulugh Beg's court; celebrating his son's circumcision, the ruler offered feasts for nobles and the general population alike during which the guests openly drank wine. The muhtasib of Samarqand, Sayyid Ashiq, publicly scolded Ulugh Beg, berating him before the guests, "You have destroyed the faith of Mohammad and have introduced the customs of infidels." 69 Ulugh Beg responded, "You have won fame

\footnotetext{
${ }^{65}$ Manz, "Mongol History," p.144. Relations between Shahrukh and the Mamluks, who at the time controlled the Holy Cities of Mecca and Medina, were not good but Shahrukh's offer of a new cover for the Ka'ba was finally accepted by the Mamluk sultan Chaqmaq in 1443-4. It is not known if the cover actually arrived or was ever installed.

${ }^{66}$ Ibid., p. 143.

${ }^{67}$ Ibid., p. 146.

${ }^{68}$ Lentz and Lowry, p. 84.

${ }^{69}$ Ibid., p. 97 . The muhtasib was a state official charged with the oversight of public morality.
} 
through your descent from Sayyids and your learning, and have attained old age.

Apparently you also wish to attain martyrdom and therefore utter rude words, but I shall not grant your wish." With the muhtasib rebuked and silenced, the public drinking continued unabashed.

The comfort Timurids felt with their blended Turco- Mongol and Perso- Islamic cultural traditions is perhaps best illustrated by Timur's mausoleum, the Gur-i Amir in Samarqand, erected by Ulugh Beg. The great tombstone is inscribed with Timur's genealogy, affirming common ancestors with Chingiz Khan and describing a lineage going back to the mythological Mongol ancestress, Alanqua, who was, in ancient Mongol legend, impregnated by a heavenly light. Ulugh Beg, in a classic Timurid melding of traditions, identified the paternal light as the spirit of "one of the descendants of the prince of the Faithful Ali ibn Abu Taleb., ${ }^{70}$

On the murder of Ulugh Beg by his ambitious son, Abdul Latif (d. 1450), who himself would rule for only six months before being murdered for his act of parricide, the Timurid princes declared full autonomy and campaigned across the region and against each other to expand their assigned appanages. The central lands of Timur's empire had become politically fractured within fifty years of his death, in large part due to ambiguous succession traditions and the development of competing princely courts in semi-autonomous appanages. Never again would Mawarannahr be united under the rule of a single Timurid king.

\footnotetext{
${ }^{70}$ This genealogy is also included within the Timurid biographies, such as Mir Dawlatshah Samarqandi's Tazkirat al-shu'ara (A Memorial of Poets), which contains biographical sketches of Timurid rulers as well as of contemporary poets. It was completed in 1487.
} 


\section{The Timurid Cultural Personality}

The later Timurids were in a more insecure position. The lineage of the Great Amir would not be sufficient to guarantee individual rival princes a political role or sustain imperial power. For that they would be required to develop legitimizing discourses of their own. Out of these conditions-- the individual need of the Timurid princes to establish political legitimacy, the specific components of the imperial image already established by Timur, the inheritance of the Turco-Mongol/ Persio-Islamic hybrid cultural and ideological fusion, and the fractured political situation in fifteenth- century Mawarannahr - Timur's successors developed a distinct and recognizable Timurid "cultural personality," a highly individual set of "social assumptions, political and cultural values and even ... aesthetic standards. ${ }^{, 71}$ In the highly competitive, fragmented world of the Timurid princely successors, shared cultural values, rather than sheer military might, would establish the identity of the Timurid elite and even provide a degree of cohesion. The distinctive social and political identity developed between the death of Timur in 1405 and the Uzbek destruction of Timurid power by 1507 came to define Timurid culture across the Islamic world.

The Timurid successor kingdoms were no longer steppe regimes in the Chingizid tradition. Public displays of kinship loyalties and nomadic ideals grew less, although they never disappeared, for power remained in the hands of Turks and Mongols, admittedly increasingly sedentarized, and much of the empire's military elite continued to be drawn from traditional nomadic elements. Evocations of Chingizid tradition could always confer a degree of political support and legitimacy, for even the princes "had

\footnotetext{
${ }^{71}$ For the use of this term to denote the Timurid identity, see Dale, Garden, p. 135.
} 
memories of Timur's court; their tutelage at the hands of his queens and amirs, and the glory of his conquests instilled in many of them deep bonds with the history and traditions of the Turco- Mongol steppe, which had become tangential to their existence. $^{, 72}$

Yet the new post- Timur aristocracy oriented itself, as Timur had intended, towards an urban Persianate model of kingship. Shahrukh's decision to establish his imperial capital in the western reaches of the empire, leaving Timur's Samarqand to the rule of his governor son while he himself remained in Harat, Khurasan's capital city and a center of Iranian culture, confirmed the dynasty's shift. Political legitimacy would remain tightly linked to the Chingizid-Timurid lineage and military tradition, yet PersoIslamic high culture became the privileged artistic form as unprecedented degrees of patronage at rival Timurid princely courts quickly developed into a Timurid cultural efflorescence.

As we have already seen, during Timur's lifetime his court had followed Ilkhanid tradition and maintained a high degree of artistic patronage. Artists, poets, scholars and scientists from every region of the Islamic world had been forcibly brought by Timur to Samarqand, infusing Timurid art and intellectual life with a variety of influences and styles. In 1411, however, Ulugh Beg freed his grandfather's captive artisans and craftspeople. The resultant migration brought many of them west to Harat and to other Timurid courts, for even in the stable years of Shahrukh's rule the empire had grown increasingly decentralized and the courts of the Timurid princes, serving as provincial governors, became rival centers of power and political independence. Not only were

\footnotetext{
${ }^{72}$ Lentz and Lowry, p. 95.
} 
these migrants skilled craftspeople, they were experienced in the demands of artistry at an imperial court, with "expertise in implementing royal ideologies.",73

In the tradition of Timur, the rival princes of Central Asia attentively participated in the careful production of public imperial imagery designed to establish their individual legitimacy at the expense of competitors. A series of histories was produced at various Timurid princely courts which modified aspects of Timur's personality and imperial image in order to demonstrate that Timur's charismatic legacy legitimized a particular princely line. For example, an anonymous writer at the court of Iskandar Sultan, son of Umar Shaykh, in an account of the House of Timur written in 1413, less than ten years after Timur's death, emphasized the legitimacy of his prince/patron's lineage. His particularly suspicious condemnation of his patron's uncle, Shahrukh, as "parsimonious" and "lacking in redeeming qualities" was far-sighted, for only one year later Shahrukh defeated Iskandar Sultan in his kingdom of Fars and blinded him, thereby disqualifying him for rule. ${ }^{74}$ Yazdi’s Zafarnama, which was commissioned by Ibrahim Sultan (Shahrukh's second son, 1394-1435) and completed in 1425 using Shami's Zafarnama as the main source of information, plays down Timur's links to the Chingizid past and emphasizes his Islamic loyalties, describing Timur as the rightful successor to earlier "legitimate" rulers in Islamic Iran, a strategy which could be read as advancing the claims of Shahrukh, the prince best known for conservative religious leanings, and his line. ${ }^{75}$ Among the many histories designed to legitimize the Shahrukh line, the most important is an encompassing world history, the Majma' al-tawarikh, composed by Shahrukh's court

\footnotetext{
${ }^{73}$ Ibid., p. 119.

${ }_{75}^{74}$ Anonymous, "Synoptic Account of the House of Timur," in Thackston, CP, p. 242.

${ }^{75}$ Lentz and Lowry, p. 99.
} 
historian Hafiz-i Abru (d. 1430). The Majma'al-tawarikh narrates human history from Adam to the Timurid Shahrukh, using large portion of the histories of Rashid al-Din and Shami, "to reinforce Timurid claims to succeed earlier Mongol rulers as well as Islamic caliphs and kings." 76 The calculated humility of Timur, who refused the titles khan and caliph, was not a strategy which would be employed by his sons. In death, Timur's legacy would be developed and expanded to encompass the political needs of his Timurid successors.

\section{Religious and Literary Patronage}

Located in this zone between the two halves of the Timurid identity, TurcoMongol and Perso-Islamic, religious loyalties remained fluid and heterogeneous. The Timurids were Sunni, of the Hanafi mazhab, the most common Islamic legal rite among the Turkish tribes, but inclinations to Shi' ism emerged occasionally among the princes. This was true particularly in the fifteenth century, when something of a conflation of Sufism and Shi' ism was taking place in Mawarannahr prior to the founding of the Safavid state. Timurid princes openly patronized Shi $i$ shrines, the most famous being the "rediscovered" grave of Ali ibn Abu Taleb at Mazar-i Sharif, the shrine of Imam Riza at Mashhad, and the tomb of Abdullah Ansari at Harat, all of which became important pilgrimage centers, seen by some as acceptable substitutes for the hajj. ${ }^{77}$ It was in fact under the rule of Shahrukh, conservative Sunni Muslim though he was known to be, that both Mashhad and Mazar-i Sharif were "discovered," although it was his wife, Gawarshad, who publicly served as their imperial patron.

\footnotetext{
${ }^{76}$ Woods, "Timurid Historiography," pp. 96- 99. Also see Lentz and Lowry, p. 98.
} 
As king, Abu Sa 'id, Timur's great- grandson, who would be brought to power by the conservative Sunni Naqshbandi Shaykh Khwaja Ubaydullah Ahrar, minted coins that carried both Sunni and Shi'i verses. ${ }^{78}$ The Timurid prince of Harat, Sultan Husayn Bayqara (1438-1506), attempted to have the names of the twelve imams included in the reading of the khutba but was dissuaded by members of his court circle, Abdul- Rahman Jami (1414- 92) and Ali Shir Nava'i. ${ }^{79}$ Sultan Husayn's son, Muhammad Husayn Mirza, became a devotee of Shah Ismail, messianic leader of the Safavids, only to later become a committed Shi' i (galiz rafizi). ${ }^{80}$ There was certainly a degree of religious flexibility amongst the Timurids, although modern scholars must be cautious, in that a general reverence for the lineage of the prophet, described as ahl-i baytism (veneration of the People of the House), was common among fifteenth- century Central Asian Muslims, and should not necessarily be read as a rejection of Sunni identity or an indication of Shi' $i$ loyalty ${ }^{81}$

Muslim religious allegiances among the Timurid princes were perhaps generally sincere, but their expression was pragmatic and often manipulated in the interests of temporal power and legitimacy. As part of his great project of legitimation, Timur had taken great care to confirm his Islamic loyalties, but his careful attention to Chingizid tradition caused many, perhaps accurately, to view his religious leanings as a matter of expedience rather than sincere belief. Within fifteenth-century Central Asian Islam, however, mystical orders had gained enormous popularity and influence, and it was in his

\footnotetext{
${ }_{78}^{77}$ Lentz and Lowry, p. 88.

${ }^{78}$ Ibid., p. 253. Abu Sa'id (1424- 69) was the son of Sultan Muhammad, son of Miranshah, son of Timur. He was also the father of Umar Shaykh, and therefore the grandfather of Babur.

${ }^{79}$ Baburnama, Mano, p. 254.

${ }^{80}$ Ibid., Mano, p. 258.
} 
generous patronage of specific Sufi orders that Timur found a vehicle through which to publicly affirm his Islamic allegiance.

With the loss of Timur and the rapid decentralization of his empire, however, the mystical orders of Timurid Central Asia grew increasingly independent of imperial authority and better able to make demands on political leaders. The Naqshbandi order of Sufis, with origins in the twelfth century, had by the fifteenth developed its distinctive practice of silent repetition of the name of God (zikr), eschewing the more common Sufi practices of music and dance (sama) and replacing them with a doctrine of "solitude in society" (khalwat dar anjuman), which was interpreted as requiring involvement with political leaders "in order to influence their thoughts and policies." ${ }^{\$ 2}$ During a century of Naqshbandi expansion and consolidation in which the order became the premier Sufi brotherhood in early modern Central Asia, the spiritual leadership of the Naqshbandi order developed increasingly intimate relations with Timur's contentious successors.

Under the leadership of Naqshbandi shaykh Khwaja Ubaydullah Ahrar (14041490), the Naqshbandi order developed into an economically and politically powerful entity, rapidly expanding outside of Transoxiana with the departure for the Ottoman Empire and Iran of Ahrar's thirty- three principal khalifas. Within Transoxiana, Ahrar's activities as spiritual guide and political advisor to princes put him in a position to mediate for their subjects, offering the peasants his patronage and protection while

${ }^{81}$ See Robert McChesney, Waqf in Central Asia, 1480- 1889, Princeton: Princeton University Press, 1991. ${ }^{82}$ K. A. Nizami, "Naqshbandi Influence on Mughal Rulers and Politics," Islamic Culture 39 (1965), p. 41. The silent $z i k r$ allows for the constant repetition of the names of God while engaged in normal public social activity. 
actively expanding his own vast influence and enormous personal wealth. ${ }^{83}$ The power of the shaykh was much greater than that of the region's temporal leadership, a clear indication of the decline in Timurid unity and power.

The peak of Naqshbandi involvement in the political and economic affairs of the Timurid princes occurred under the leadership of Ahrar, who used his considerable spiritual and economic powers to influence the outcomes of the regular and devastating succession wars among rival Timurid princes. The four major extant biographies of Ahrar agree that the shaykh's support of Timur's grandson, Abu Sa'id (1424- 1469), expressed through miraculous displays of personal spiritual charisma, played a key role in the prince's political success. His influence on Abu Sa'id, who "always considered himself to be that hazrat's agent," ${ }^{84}$ grew increasingly unassailable and Ahrar moved from his native Tashkent to Samarqand and Harat, where for nearly forty years he became "virtual ruler of Transoxiana." $" 85$ As the few extant records of his vast waqf holdings illustrate, "the synthesis of two sources of power and prestige (spiritual leadership and accumulated capital) placed Khwaja Ahrar in a unique position of power." 86

Ahrar arbitrated for a long list of Timurid princes, who made public displays of their allegiance to the Naqshbandi leader. "The Moghuls [Mongols] revered him [Ahrar] so much that no one dared to meet him personally. In droves they came, men and

\footnotetext{
${ }^{83}$ Jürgen Paul, "Forming a Faction: The Himayat System of Khwaja Ahrar," International Journal of Middle Eastern Studies, 23, 4 (Nov. 1991), pp. 533.

84 'Abd ar-Razzaq Samarqandi, Matla 'i Sa'dain, II, Tehran (1949), p. 1062, cited in JoAnn Gross, "Multiple Roles and Perceptions of a Shaikh," Naqshbandis, Marc Gaborieau, et al, eds., 1990, p. 117. See also JoAnn Gross, "Khoja Ahrar: A Study of the Perceptions of Religious Power and Prestige in the Late Timurid Period," unpublished PhD dissertation, New York University, 1983.

${ }^{85}$ Hamid Algar, "The Naqshbandi Order: A Preliminary Survey of Its History and Significance," Studia Islamica 44, 136 (1976), p.138.
} 
women, and stood dismounted from afar. When His Holiness had passed by, they threw themselves into the road and gathered up the dust. The khan went by himself to greet the saint, and when he drew near, the khan dismounted, stood transfixed, and then fell down in front of His Holiness and remained rubbing his ruby-red face on the black dirt." ${ }^{97}$ There was no distinction made between Timurid and Chaghatay, Turk and Mongol; Ahrar's followers included Babur's maternal grandfather, the Mongol Yunus Khan, his Timurid uncle, Sultan Ahmet Mirza and his father, Umar Shaykh Mirza. In their Timurid appanage in the Ferghana valley Babur, his father, and very likely several of his maternal (i.e., Chaghatay) uncles, became Ahrari murids. ${ }^{88}$ In his memoir Babur described his father's reliance on Ahrar, writing, "As his highness the Khwaja was there, accompanying him step by step, most of his affairs found lawful settlement." ${ }^{\prime 89}$ The loyalty and respect felt for the order by both the general population and the Timurid ruling elite was expressed through political and economic patronage, which resulted in a thorough entrenchment and integration of the order throughout Timurid Transoxiana and Khurasan, deeply affecting the region's understanding and practice of Islam.

The cultural understandings of the Timurid princes developed from an education in the Islamicized Persianate tradition, in which cultivated atmosphere this TurcoMongol military class, the descendants of nomadic and semi- nomadic warlords, had achieved a high degree of sophistication. The Timurid dynastic identity and ruling ethos were further defined through an increasing emphasis on imperial patronage of the arts

\footnotetext{
${ }^{86}$ JoAnn Gross, "Multiple Roles and Perceptions," p. 113.

${ }^{87}$ Mirza Haydar Dughlat, Tarikh-i Rashidi: A History of the Khans of Moghulistan, W. Thackston, tr., Cambridge, Massachusetts: Harvard University, Department of Near Eastern Languages and Cultures, 1996, p. 52.
} 
and the wholesale adoption of the Persian literary tradition. In a culture already heavily dominated by Iranian motifs and models "whose conventions and connotations would be recognized by the elites of the Iranian world," Timurid fascination with Persian forms, both literary and visual, was perhaps due in part to their value as universal symbols which marked the Timurid "transformation from a military caste into monarchs in the Iranian Islamic mold, who recognized the necessity of cultural prowess as an ideal of rule."${ }^{90}$ This was an intentionally elitist cultural movement, exclusive to the wealthy and educated, and a public demonstration of the refinement and sophistication of the individual Timurid princely courts. Although first Timur and then Shahrukh and his wife, Gawarshad, participated in the patronage of architects and artists, it was the later Timurid princes, firmly grounded in sophisticated urban culture and ruling independent rival courts, who became "the leading arbiters of literary taste through the eastern Islamic world," and were at the center of the development of a "mature and unified Timurid art that identified and redefined the ruling house. ${ }^{, 11}$

For most of the fifteenth century Harat remained the center of the Timurid cultural florescence, yet the political rivalry among Timurid princes in their various centers of power compelled them to compete for the prestige which came from patronage of esteemed artists and poets. In the increasingly fragmented political world of fifteenthcentury Mawarannahr, political prestige grew to be centered less around actual military might and on a prince's ability to coerce the region's greatest poets, artists, scientists and

\footnotetext{
${ }^{88}$ Stephen Dale and Alam Payind, "The Ahrari Waqf in Kabul in the Year 1546 and the Mughal Naqshbandiyyah," JOAS 119, 2 (1999), p. 223.

${ }^{89}$ Baburnama, Mano, p. 27. A.S. Beveridge, tr., p. 34.

${ }^{90}$ Lentz and Lowry, pp. 168 and 162.

${ }^{91}$ Ibid., p. 113.
} 
literati to his court. Perhaps it was the degree of public acclaim and attention given to specific artists at the Timurid princely courts that led Timurid artists to sign their works, for the first time in the Islamic world, an illustration of the enhanced value placed on the individual artist.

Political considerations shaped the development of a particular and innovative artistic expression which marked the identity of the Timurid successor courts, defining their character and their reputation across the Islamic world for hundreds of years. Just as Timur had drawn a public image of power and might through his massive construction projects and court-controlled historiography, his successors took pre-existing architectural forms and artistic themes, and "manipulated and distilled them until a coherent and potent imagery that glorified Timurid rule was established."${ }^{.92}$

Beneficent Timurid patronage patterns enhanced the reputations of the princes of the house of Timur and elicited awed admiration from rival dynasties. The pinnacle of Timurid courtly renown was reached by the fifteenth-century Timurid ruler of Harat, Sultan Husayn Bayqara (1438- 1506), who through a remarkable degree of royal patronage gained universal admiration and fame with his glittering court society populated by the leading artistic figures of the day, including such notables as the poets Ali Shir Nava'i (d.1501) and Abdul Rahman Jami (d.1492) and the miniaturist Bihzad. Late fifteenth-century biographies of the city's poets list more than three hundred living in Harat in this period, although Sultan Husayn Mirza suggest the presence of many more in his Apologia. Here, in the baroque Persian prose style of the period, he describes the wealth of talent assembled at his imperial court: "In the environs of Harat (May God

${ }^{92}$ Ibid., p. 56. 
protect her from catastrophe), where there come to mind and can be mentioned so many talented and discerning people, there are nearly another thousand whose job is to string pearls of meaning onto the cord of poetry and to enhance gems of precision with the garb of adornment and beauty. In no other epoch have there been ten such persons out of a thousand and in no place has there been one such person out of a hundred."${ }^{.93}$

The visual arts were represented by painted portraits and miniatures, which were passed around the salons of Harat for appraisal and criticism by a sophisticated yet increasingly effete court society. A member of this elite circle described Bayqara's Harat as "characterized by a universal preoccupation with the arts (chunarmandi) and patronage of them (hunar parvani). ${ }^{994}$ A renowned poet at the late Timurid court of Husayn Bayqara jested, "What a sad state this is that in Harat one cannot stretch out one's foot without poking a poet in the ass." 95

In Timurid Transoxiana, as in most of the Islamic world, poetry was the skill most highly prized among aristocrats and intellectuals. While the royal courts were filled with professional poets busily writing panegyrics for their patrons, most members of the elite classes tried their hand at composition, as well. It was a culture in which "ambitious Turco-Mongol aristocrats were expected to be able to compose verse." "P6 "People... played with poetry, did tricks with poems, showed off their talents with poetry, were

\footnotetext{
${ }^{93}$ Sultan Husayn Mirza, Apologia, in Thackston, CP, p. 376.

${ }^{94}$ Maria Eva Subtelny, quoting Dawlatshah in "Arts and Politics in Early Sixteenth-Century Central Asia," Central Asiatic Journal 27, 1-2 (1983), p. 123.

${ }^{95}$ Baburnama, Mano, p. 280. Thackston, tr., p. 375. This comment was made by Ali Shir Nava'i at a chess party in Harat, intended as a jibe against a competitor poet, Banni' a, who answered him, "Yes, and if you pull your foot back in, you'll poke another."

${ }_{96}$ Dale, Garden, p. 255.
} 
funny, insulting and naughty in poems.... Everyone from ruler to peasant, from religious scholar to rake and drunkard aspired to be a poet.".97

At the Timurid princely courts the arts were not a solitary pleasure but a communal affair to be enjoyed in a gathering of close companions. The vehicle for public expression of artistic skill was the majlis, a literary soiree which could take a number of forms, from that of a formal courtly recitation in a private household to an often wildly competitive poetry slam combined with rambunctious drinking and drugtaking in any one of Samarqand or Harat's myriad magnificent gardens. ${ }^{98}$ The classical garden served as the social center of the artistic elite, becoming a symbol of the golden age of late Timurid society, and, as such, was memorialized in miniature paintings and venerated in verse. Matching Timur's thirty gardens of Samarqand, Sultan Husayn Bayqara had thirty formal gardens laid out in Harat, although many were inherited, having been originally established by Shahrukh. Social gatherings in the garden were the "principal communal institution of late- Timurid social, political, and cultural life."99

Although the Timurids' military strength had begun to ebb away, their cultural authority affirmed their power as the "ultimate arbiters of sophistication and taste" throughout much of the Islamic world. ${ }^{100}$ The glittering court of the Turcoman Aqquyunlus at Tabriz, also renowned for its high degree of artistic patronage, modeled itself on the Timurid court, particularly that of the ruler of Harat, Sultan Husayn

\footnotetext{
${ }^{97}$ Walter G. Andrews, Najaat Black and Mehmet Kalpaki, eds. and trans., Ottoman Lyric Poetry, Austin, Texas: University of Texas Press, 1997, p. 4.

${ }^{98}$ Ibid., p. 140.

${ }^{99}$ Lentz and Lowry, p. 165.

${ }^{100}$ Ibid., p. 299.
} 
Bayqara. ${ }^{101}$ Other non- Timurid contemporaries of the Mughals, the Ottomans, Uzbeks and Safavids, shared the sense that perhaps the greatest legacy of the late Timurids was their extraordinarily intimate and generous artistic patronage. Their awareness of Timurid court custom was in part due to the numbers of poets and artists who migrated out of Timurid territories and spread the word of a royal dynasty whose artistic patronage had reached unprecedented heights. As early as 1422, the writer Ahmad ibn Abdullah alHijazi, recently arrived in Ottoman Edirne and anxious to find employment, composed a letter requesting the patronage of the Ottoman sultan. In order to encourage Ottoman beneficence, he invoked the Timurid example, writing, "The sultans of the age, too, like Ibrahim Sultan, Ulugh Beg, and their father Shahrukh Mirza, have taken notice of this art for 'people follow their king's religion.' In the kutupkhana of each of these there is a group of learned people without equal in the world —copyist, illuminator, illustrator, book binder...."102

Initially propagated in the interests of dynastic power at the juncture of TurcoMongol and Perso- Islamic traditions, Timurid patronage patterns and Timurid artistic and literary imagery would resonate throughout the Islamic world and establish an enduring historical legacy. Yet in the writings of the Timurid fin de siècle, we begin to glimpse an increasing weakness and loss of military might among Timur's disunified, competitive successors. On the eve on the Uzbek conquests, the Timurid world seems to have been busily engaged in artistic rivalry and garden parties, ignoring the signs of impending destruction of not only their political power but, by extension, the

\footnotetext{
${ }^{101}$ Ibid.

${ }^{102}$ Letter from Ahmad ibn Abdullah al- Hijazi, (Istanbul Universitesi Kutuphanesi, F.1423, fol. 35b), in Thackston, CP, pp. 330-2.
} 
sophisticated Timurid court culture so elaborately developed and universally

acclaimed. $^{103}$

\section{Babur's Mawarannahr and the Timurid Denouement}

By the time of Timur's death, the heartland of his conquest territories was the sparsely populated region known as Mawarannahr, the land area between the two great rivers of Central Asia, the Amu Darya and the Syr Darya (known in the Western world by their Greek names, the Oxus and the Jaxartes). In the fourteenth century, the northern portions of this territory comprised primarily an arid steppe populated sparsely by nomadic pastoralists, surrounding the oasis cities of Khiva and Tashkent. In the south, high mountains were split by small, fertile river valleys in which semi- nomadic peoples traveled fixed seasonal migration routes, settled populations farmed, and the cities of Samarqand and Bukhara were sustained and linked by ancient trade routes. The Iranian territories were markedly urban, settled, Islamicate and culturally sophisticated, including the rich oasis city of Harat, the capital city of Khurasan, the northeastern portion of the Iranian plateau and the only part that remained closely tied to Mawarannahr after Timur's death.

At the time of Babur's birth, in 1483, Mawarannahr was ruled by five autonomous Timurid princes, including Babur's father and three paternal uncles, all descendants of Timur's third son, Miranshah. The nominal governor of Mawarannahr was Sultan Ahmad Mirza (1451-1494), who was the eldest of Miranshah's sons but in fact controlled only the two great cities of Samarqand and Bukhara. His brother, Sultan

\footnotetext{
${ }^{103}$ For a discussion of the decline of sedentarized Timurid society in the context of the writings of Ibn
} 
Mahmud Mirza (1453-1495), controlled, until a year before his death, the region of the upper Oxus river valley, including the centers of Hisar, Termez, Qunduz and Badakhshan. The third brother, Ulugh Beg Kabuli (d. 1502), was ruler of Kabul, while Babur's father, Umar Shaykh Mirza (1456-1494), ruled the valley of Ferghana, a rich agricultural region. The fifth ruling Timurid prince was Sultan Husayn Bayqara (14691506), a descendant of Timur's eldest son Umar Shaykh, who controlled the enormous appanage of Iranian Khurasan, centered on Shahrukh's capital city of Harat, and Khwarazm, stretching from below the Aral Sea to Qandahar in Central Afghanistan.

To the east, between Mawarannahr and Western China, was the region known as Mughulistan, Mongol territories ruled by Babur's maternal grandfather Yunus Khan (d. 1487), who was descended from Chingiz Khan through his second son Chaghatay. Yunus Khan's eldest son, Sultan Mahmud Khan (d. 1509), ruled the city and hinterland of Tashkent, while his brother Sultan Ahmad Khan (d. 1504) controlled Aqsu and the region of Alti Shahr (Six Cities) in northern and eastern Mughulistan along the southern skirt of the Tien Shan Mountains. ${ }^{104}$ Both sons were married to women of the Dughlat Mongol clan, who historically had been the amirs of Kashgar under Chaghatay.

Rivalry and competition for territory raged, and constant low-grade warfare marked the period, yet no outsiders ruled in Mawarannahr; the mirzas and amirs were deeply interconnected through both blood ties and marriage, and Babur, son of a Timurid father and Chingizid mother, could claim direct family connections to all of the rulers of Central Asia as nephew, cousin, son or grandson. When Babur's father died in a fall from his dovecote, leaving his twelve-year-old son to inherit the appanage of Ferghana, it 
was not outsiders but Babur's rapacious Timurid- Mongol uncles who posed the first and most immediate threat to the boy's inheritance. Yet while rulership in Babur's Mawarannahr was uncertain, transitory and constantly negotiated, perhaps it was the close family connections which prevented the constant military skirmishes from becoming deeply destructive. Babur's Ferghana was protected from his acquisitive uncles, although only briefly, thanks in large part to the diplomatic interventions of his grandmother and loyal counselors.

While Babur's relations did not hesitate to take advantage of his youth and perceived weakness in attempting to seize his appanage, it is important to note that no one in late fifteenth-century Mawarannahr, Chaghatay or Timurid, seems to have indulged in the scorched earth tactics of his ancestors' armies. Women and children were generally released from captivity unharmed, while followers and factions who shifted loyalties without notice incurred punishment for their fickleness only very rarely. In Babur's descriptions of warring male relatives, it is interesting to note how much of the constant threat and chaos was resolved through saber rattling and negotiation, while few actual battles took place. His father, Umar Shaykh, fought in only three battles in his lifetime, one with his father-in-law, Yunus Khan, one against an Uzbek raiding party, and the third against his brother, Sultan Ahmad Mirza. He lost two of the three battles. ${ }^{105}$ Babur himself describes his own "first real battle" as taking place in the year 1499- 1500, when he had already defended Ferghana against his uncles, taken Samarqand, lost it, and

\footnotetext{
${ }^{104}$ For Babur's early milieu in Mawarannahr, see the Baburnama and Stephen Dale, Garden.

105 Baburnama, Mano, p. 12- 13. Umar Shaykh, in his first battle, lost to Yunus Khan and was taken prisoner but was "treated kindly" and eventually released to return to his province. Babur does not date the battle nor indicate that this was, as one might presume, prior to Umar Shaykh's marriage to Babur's mother, the daughter of Yunus Khan. Umar Shaykh won his battle with the Uzbeks, and Babur is quick to
} 
lost Ferghana again and was engaged in re-taking it. Even this "real battle" was not

warfare on a massive scale; "the battle never reached the right wing or the vanguard," and although Babur's carefully arranged foot soldiers fell behind, "thank God there was found to be no need of them (Tengri 'inayeti bile alarga hich ihtiyaj bulmadi)."106

All of this was to change with the invasion of the Uzbek tribal confederation, led by Shibani Khan (1451-1510), a grandson of the Uzbek hero Abu al-Khayr, who had briefly united the tribes only a generation earlier. ${ }^{107}$ Shibani Khan began an invasion of Mawarannahr and Khurasan in the last decades of the fifteenth century, and died in 1510 as Great Khan, in control over most of Central Asia. In this startlingly short time he had overrun the heartland of Timurid Central Asia and put the Timurid-Chaghatay elite to flight.

In reading the contemporary sources, one is struck by the general Timurid inability to cope with an invasion by outside powers. The grandsons and greatgrandsons of Timur ignored the military threat until it was too late to defend themselves, concentrating instead on their continuing family disputes, for the sake of which alliances with the Uzbeks were not uncommon. In Shibani Khan's earlier conquests, success was achieved almost entirely through the connivance of Timurid princes on the Uzbek's

describe his father's careful return of all Uzbek booty to its original owners, "without coveting a single thing for himself." He was defeated in the battle against his brother, his last act of war.

${ }^{106}$ Baburnama, Mano, p. 104.

${ }^{107}$ Uzbek is an inappropriate term to use for this group, although it is the common usage among modern scholars. Properly speaking, these are Jochids, descendants of Chingiz Khan through his eldest son, Jochi, with the group we are most interested in being the descendants of Jochi's son Shiban, hence the appellation "Shibanid." The descendants of another of Jochi's sons, Toqay Timur, became known in the Persian sources as the Ashtarkhanids, because of their origins in Astrakhan. Within a year of Shibani Khan's death the Shibanid Uzbeks lost control of Mawarannahr to rival clans. They competed with the Ashtarkhanids for control of Central Asia through the late sixteenth century in a relationship that resulted in a bipartite Uzbek state from 1612 to the early eighteenth century, when it disintegrated under the pressure of decentralizing amirs. 
behalf. It was with the aid of Sultan Mahmud Khan, a son of Abu Sa'id and uncle of Babur, that Shibani Khan was able to take Bukhara and Samarqand with an army of 60,000 , after which success the other Uzbek "princes and amirs wandering without a leader in the Qipchaq Steppe joined him." 108 The continued alliances with and support of various Timurid and Chaghatay nobles sustained Shibani Khan through his years of conquest, ultimately allowing him to establish himself as ruler of the Timurid heartland. All the carefully nurtured attributes of imperial power that had come together to define the Timurids as a community ultimately failed them in the crisis of Uzbek invasion, and their complete disunity left them utterly vulnerable. "No factor, neither kinship, nor religion, nor language, nor age, nor love of chess or poetry or drink, nor nostalgia for past glories - nor any shared social connection, cultural characteristic or personal habitensured lasting political cooperation among them."109

Perhaps even more disabling to the Timurids than their inability to organize as a group to fight off the common threat was the way in which their dynastic monopoly and the relative ease, or at least manageability, of their familial rivalry had eaten away at their military might. The sedentary lifestyle they had constructed, which glorified the dynasty through artistic patronage and aesthetic appreciation rather than military experience or territorial ambition, robbed them of their ability to respond forcefully to the onslaught of Uzbek steppe warriors. As an illustration of their changing self- image, late Timurid arts reflected subtler, smaller, more nuanced dimensions of power. While in the early years, the Timurid kings had employed the arts as public displays of power, theatrical statements of legitimacy and outward manifestations of imperial strength, these efforts

${ }^{108}$ Mirza Haydar Dughlat, Tarikh, pp. 99-102. 
came to be traded for increased intimacy and introversion. By the end of the fifteenth century, "etiquette and formality had replaced boldness and action."110

Writing years later, in the comparative comfort and safety of Kabul, Babur expressed deep frustration at the Timurid lack of response in defending Mawarannahr. He claims to have tried to raise the alarm, insisting that "an enemy like Shibaq [Shibani] Khan had arrived on the scene, and he posed a threat to Turk and Mughal [Mongol] alike (muning sarari Turkka va Mugulga muzavi dur.). He should be dealt with now while he had not yet totally defeated the nation or grown too strong, as has been said:

Put out a fire while you can, For when it blazes high it will burn the wood.

Do not allow the enemy to string his bow

While you can pierce him with an arrow.

Imruz bikush chu mituvan kusht atesh chu buland shud jahan sukht

Makzar ki zeh kunad kaman ra dushman chu ba tir mitavan dukht."111

The Timurid- Chaghatay response to Babur's warning was vague and dismissive.

The last great Timurid king, Sultan Husayn Bayqara, famed for his glittering court, had in his youth been an able warrior, but, according to Babur, upon settling in conquered Harat with all his followers and retainers, he "indulged in revelry and carousal. He abandoned the toil and trouble of conquest and military leadership (jahangirlik u lashkarkashlik ranj u ta'bin tartmadi)."112 "For the forty years he was king in Khurasan he didn't pass a day without drink after the midday prayer.... His sons

\footnotetext{
${ }^{109}$ Dale, Garden, p. 72.

${ }^{110}$ Lentz and Lowry, p. 298, for a fascinating and more detailed discussion of the shift in Timurid art to reflect a narrowing of the imperial vista.

${ }^{111}$ Baburnama, Mano, p. 152. Thackston, tr., p. 205.
} 
and all his military and civilian men were addicted to drink and lived with voluptuousness [ifrat bile 'aysh; gratification of the appetites] and immoral conduct [fisq; slighting the commands of God]." ${ }^{, 113}$ Not only the great king but his fourteen sons failed the Timurid dynasty in the face of the Uzbek armies. Babur visited Harat between the death of Sultan Husayn and the Uzbek takeover, and although he expressed deep admiration for the highly developed court culture of Timurid Harat, he was horrified by the effete ineptitude of the Timurid princes. Their personal discourtesies he generously blamed on hangovers rather than arrogance, but it took months for them to prepare for war. ${ }^{114}$ By the time the Bayqara princes organized their attack on the Uzbeks, the enemy had grown in size and become too dangerous for their limited forces, and the Timurid assault was delayed indefinitely. Babur was appalled, writing, "Although these mirzas [princes] were outstanding in the social graces, they were strangers to the reality of military command and the rough and tumble of battle." ${ }^{" 15}$

Yet although he later expressed deep disappointment in the dubious military planning and organization of his cousins, Babur, who so loved the Timurid cultural ideal, passed his days in Harat in excursions to the gardens, monuments and shrines of the Timurid kings. In later years he gave a remarkably detailed and lengthy list of these sites in his memoirs. Claiming to have missed seeing only Sultan Husayn Mirza's khanaqah, Babur visited every site through which the Timurid kings of Harat had affirmed their power and might. Babur's lovingly detailed list included:

\footnotetext{
112 Ibid., Mano, p. 256. Thackston, tr., p. 343.

113 Ibid., Mano, p. 254.

114 Ibid., Mano, p. 290.

${ }^{115}$ Ibid., Mano, p. 293.Thackston, tr., p. 392.
} 
Gazargah, Ali Sher Beg's garden, Juwaz-i Kaghiz, Takht-i Asitana, Puligah, Kahdistan, the Nazargah Garden, Ni'matabad, the Gazargah Avenue, Sulan- Ahmad Mirza's burial enclosure, the Takht-i Safar, the Takht-i Nawa'i, the Takht-i Barkir, Takht-i Hajji Beg, Shaykh Baha'uddin Umar, Shaykh Zaynuddin and Mawlana Abdul- Rahman Jami's shrines and tombs, the Mukhtar namazgah, the Hawz-i Mahiyan, Saq Salman and Buluri, which was originally the shrine of Abu'l Walid, Imam Fakhr, the Khiyaban Garden, the Mirza's madrasas and tombs, Gawarshad Begim's madrasa, tomb, and Friday mosque, the Zaghan Garden, the Naw Garden, the Zubayda Garden, the Aq Saray built by Sultan Abu'l Sa'id Mirza outside the Iraq Gate, Puran, the Suffa-i Tirandazan, Cheragh Meadow, Amir Wahid, the Malan Bridge, Khwaja Taq, the Safid Garden, the Tarabkhana, the Jahannara Garden, Kushk, the Muqawwawakhana, the Susanikhana, the Duwazdah Burj, the great pool on the northern side of Jahanara, and the four structures along its four sides, the five gates to the fort, the Malik gate, the Iraq Gate, the Firuzabad gate, the Khush Gate, the Qipchaq Gate, the Malik Bazaar, the marketplace, Shaykh alIslam madrasa, the Malik's Friday mosque, the Bagh-i Shahr, Badi' al-Zaman Mirza's madrasa on the banks of the Injil Canal, Ali- Shir Beg's quarters, which were called Unsiyya, his tomb and Friday mosque, which were called Qudsiyya, his madrasa, and khanaqah called Khalasiyya and Ikhlassiyya, and his bath and hospital, which were called Safa'iyya and Shifa'iyya. I saw all of these in a brief time. ${ }^{116}$

Harat reaffirmed for Babur, himself a poet of note, the glory of Timurid kingship and he was clearly enchanted, writing later that "we had come to a fabulous city... where all the implements of pleasure and enjoyment were close at hand." ${ }^{, 17}$ Harat, beloved capital of Shahrukh, with its origins in ancient Persian culture, its rich dynastic history and monuments to Timurid glory, its gardens resonant with poetry and the sophisticated banter of the age's greatest intellects and artists, would remain for Babur-- along with Timur's capital city of Samarqand, already lost to him twice-- a symbol of Timurid culture and grandeur at its most admirable pinnacle. Yet within the year, in 1507, Shibani Khan's Uzbek warriors would take Harat after a completely pathetic defense by the few remaining Timurid forces in the city. Babur, so recently in the city and therefore all the more sensitive to the loss, wrote bitterly that "the fortress was not made fast, battle

\footnotetext{
${ }^{116}$ Ibid., Mano, pp. 298-99.

${ }^{117}$ Ibid., Mano, p. 296. Thackston, tr., p. 397.
} 
weapons were not made ready, reconnoiterers and scouts were not sent to give advance information on the enemy's advance, and the army was not adequately prepared for battle should the enemy approach. ${ }^{118}$

It is no wonder that Babur would remember his days in Harat with such nostalgia-heightened detail, or that he would remain unforgiving in his condemnation of the extended Timurid dynasty. Their soft lives and decadent court culture, he felt, while enabling them to carve a pheasant at table and spontaneously spout poetry in classic Persian forms, had robbed them of their warrior attributes and resulted finally in the loss of not only the Timurid capital of Harat but all of Mawarannahr and, perhaps even more importantly, the cultural efflorescence of the Timurid courts. Babur made a blanket condemnation: "In himself [Sultan Husayn Mirza] his sons, his people and his nation, vice and debauchery were rife and rampant. It was only due to their shamefulness that, of such a great house, within seven or eight years, the only trace of them left was Muhammad Zaman Mirza."

\section{The Rout of the Timurids}

The Uzbek onslaught was quick and thorough. Sultan Husayn's two sons had been left to rule Harat, but "Sultan Badi' al-Zaman Mirza and Muzaffar Husayn Kuragan [Guregen], along with most of the great amirs and soldiers, acted in accordance with the

\footnotetext{
${ }^{118}$ Ibid., Mano, pp. 321-2. Thackston, tr., pp. 432- 3.

${ }^{119}$ Muhammad Zaman Mirza, son of Sultan Husayn Bayqara's son Badi’ al-Zaman (Badi'uzzaman) Mirza, became the last independent prince of the Bayqara line when his father fled Harat and died in exile in Anatolia of the plague. He remained in the region, struggling to carve out a kingdom for himself, until Babur, always attentive to Timurid relatives, later appointed him ruler of Balkh.
} 
dictum, 'Flee what cannot be borne,' and each fled in rout in another direction....",120 Although Babur's descriptions of Uzbek atrocities were perhaps exaggerated out of personal fear and loathing, other witnesses confirm that the Timurid elites of Harat and Samarqand suffered from the Uzbek invasion and occupation; Harat's treasury was sacked, jewels and treasure beyond measure were sequestered, and the city's inhabitants were tortured by Uzbek soldiers until they handed over hidden valuables. An eyewitness wrote, "Indeed the meaning of the Quranic verse, 'Verily kings, when they enter a city by force, lay waste the same, and abase the most powerful of the inhabitants therein,' was fully realized, and the cries of many people of quality and station, reduced to misery and degradation, rose to the celestial spheres." ${ }^{121}$

In the Uzbek conquests of Samarqand and Harat, even members of the religious elite were put at risk. Shibani Khan had the powerful Naqshbandi Shaykh Khwaja Yahya and his two sons, Khwaja Muhammad Zakariya and Khwaja Baqi, killed outside of Samarqand after his invasion of 1500-1 (906 AH). ${ }^{122}$ Shibani Khan later denied responsibility for these deaths at the hands of his Uzbek soldiery. Indeed, once his conquest was complete, he and his successors, as conservative Sunni Muslims, nurtured their intimate relationship with the powerful Naqshbandi order. Yet surely the murder of these religious men illustrates Shibani Khan's recognition that the Khwajas were so closely allied with the Timurid princes that their power and influence had become inextricably intertwined.

\footnotetext{
${ }^{120}$ Khwandamir, Habib al-Siyar in Thackston, CP, p. 232.

${ }^{121}$ Ibid..

${ }^{122}$ Baburnama, Mano, p. 118-9.
} 
In describing the defense of Timurid Harat, Babur comments bitterly on the inadequate protection afforded the Timurid women and children.

When they [the Heratis] learned of it [the approach of Shibani Khan], they went to pieces and were unable to do anything - neither could they gather their men nor were they able to array their forces. Instead each set out on his own. The princes' mothers, sisters, wives and treasuries were in the Ikhtiyar al-Din Fortress, which is now known as Ala Qurghan. The princes... could give no thought to fortifying the fortress. At such a juncture they left their mothers, sisters, wives and children to be taken prisoner by the Uzbek and fled. Sultan Husayn Mirza's wives, with Payinda Sultan Begim and Khadija Begim [Babur's paternal aunts] at the head, as well as Badi' al-Zaman Mirza's and Muzaffar Mirza's wives and small children and the princes' treasuries and workshop were all inside the Ala Qurghan. Neither had they fortified the fortress adequately nor had the reinforcements for the fortress arrived.... Thereupon the people inside the fort lost heart and, unable to hold the fortress, gave themselves up.

When Shibani Khan took Harat," mourned Babur, "he even maltreated the prince's wives and children (bu padshahlarning zah u zade bile yaman ma'as qildi.)." ${ }^{123}$ An observer, the historian Khwandamir, in the more florid language of the Timurid courtier, wrote, "The delicate beauties of the inner sanctum of inviolability were taken captive and tormented by the merciless Uzbeks, and Venuses of the chambers of chastity were left by ravaging Mughuls [Jochid Mongols and their Chaghatay allies] to wander destitute in the lanes and bazaars." ${ }^{124}$

As our witness so delicately insinuates, the elite women of the royal Timurid lineage did not escape the Uzbek invasion unscathed. In flight from Samarqand in 150102, Babur managed to take his mother with him in his desperate escape but claims that Khanzada Begim, his elder sister and full sibling, remaining in the city with the Uzbek

\footnotetext{
${ }^{123}$ Ibid., Mano, p.322.

${ }^{124}$ Khwandamir, Habib al-Siyar, in Thackston, CP, pp. 232-3.
} 
conquerors, "fell into Shibaq Khan's hands as we were leaving." ${ }^{25}$ Babur's cousin and his daughter remember the situation differently, suggesting that Khanzada Begim was purposefully left behind to serve as ransom to ensure the safety of the tiny cluster of fleeing Timurids: Babur, his mother and a few women of their household. ${ }^{126}$ Within a few days they were joined by others who had fled Samarqand, including a lady in the service of Babur's mother, Atun, who had been left behind because of a lack of mounts but had managed to walk from Samarqand all the way to Pishagar, on the road to UraTyube. $^{127}$

Considering the limitations of the sources regarding women of the TimuridMongol world, it is surprisingly simple to identify a startlingly large number of forced marriages, like that of Khanzada Begim, imposed upon Timurid princesses by the successful Uzbek warriors. Although they were themselves the direct descendants of Chingiz Khan through his eldest son Jochi and claimed to despise the prosaic origins of Timur, the Uzbeks were very much aware not only of Timurid cultural prowess but also of the power of the Timurid lineage in establishing political legitimacy in fifteenth and sixteenth-century Transoxiana. Only a hundred years earlier, Chingizid lineage alone would have been justification enough for any conqueror, as illustrated by Timur's adoption of "son-in-law" status after marrying a Chingizid princess, but by the end of the fifteenth-century the lineage of Timur had developed its own prestige. In a situation

\footnotetext{
${ }^{125}$ Baburnama, Mano, p. 141.

${ }^{126}$ Mirza Haydar Dughlat, Tarikh, p. 133, and Humayunnama, p. 3.

${ }^{127}$ Baburnama, Mano, p. 142. She is listed as a guest at the wedding feast of Babur's son, Mirza Hindal, held in Agra in 1537 and, according to Beveridge, seems to have been given a village near Kabul by Babur as reward for her loyalty. It was during this episode in Pishgar, by the way, that Babur records having met a 111-year-old woman who remembered the occasion of Timur's invasion of Hindustan. She herself had a relative who had served in that army. It is interesting to speculate how this conversation may have
} 
reminiscent of the early fourteenth-century Timurid marriages into the Chingizid line, princesses of the royal blood, as bearers of a deeply charismatic lineage, became valuable bargaining chips, the spoils of war. ${ }^{128}$ Throughout the chronicles of the period runs the theme of forced marriage.

In July 1500, the eldest daughter of Yunus Khan and first cousin of Babur, Mihr Nigar Khanim, was captured by Shibani Khan and forcibly married to him, "as part of the spoils." 129 They were divorced one year later when Shibani Khan resolved to marry her Timurid niece Khanzada, and Mihr Nigar Khanim eventually rejoined Babur in Kabul. ${ }^{130}$ Qutliq Khanim, another Chaghatay Mongol, was married "as a sequel of victory by Shaibani [sic] over her father." 131 Rabi a Sultan Begim, daughter of Sultan Ahmad Mirza Miranshahi, was married to Jani Beg Uzbek after his cousin Shibani Khan murdered her father and son in $1508 .^{132}$ On the taking of Tashkent in 1501-2, Shibani forcibly married the Chaghatay princess Dawlat Sultan to his son Timur, by whom she had a daughter. She fled her husband in 1511 to join Babur when he took Samarqand. ${ }^{133}$ Sultanum Begim Miranshahi, fourth daughter of Sultan Ahmad Mirza, was also married to Shibani Khan's son after her husband Ali, son of Mahmud Mirza, was killed by

influenced Babur's thinking when he much later chose to expand from Kabul into Hindustan. See Baburnama, Mano, p. 143.

${ }^{128}$ Although there is no record of the early Timurids engaging in the same degree of forced conquest marriage as the later Uzbeks.

${ }^{129}$ Mirza Haydar Dughlat, Tarikh, p. 132.

${ }^{130}$ Ibid., p. 133. Humayunnama, Beveridge Appendix (cited hereafter as BA), p. 264. Mihr Nigar left Kabul in 1507 to join family members on a visit to Badakhshan, which was led by Shah Begim Badakhshi in an attempt to claim the hereditary territory for her grandson. On the journey she was captured by "one of Abu Bakr Dughlat's marauding bands" and died in his prison in Kashgar. See Humayunnama, BA, pp. 265 and 284.

Of course, Uzbek marriages to the women of the Chaghatay branch of Chingizids would also have been a conscious enhancement of their Jochi lineage, particularly in Chaghatayid lands like Mawarannahr. Hence Khanzada's value as half-Timurid, half-Chaghatay, like her full brother Babur.

${ }^{131}$ Mirza Haydar Dughlat, Tarikh, p. 95. Humayunnama, BA, p. 272.

${ }^{132}$ Mirza Haydar Dughlat, Tarikh, p 63-4. Humayunnama, BA, p. 274. 
Shibani Khan. ${ }^{134}$ Babur's cousin, Habiba Sultan Khanish Dughlat (full sister of the chronicler Haydar Dughlat Mirza), was taken by Shibani Khan when she was a child and remained in his household until young adulthood, when she was married to his nephew, Ubaydullah. When her Uzbek husband retreated to Turkestan in 1511, Habiba remained behind, eventually marrying her cousin. ${ }^{135}$

When Shibani Khan took Andijan and Akhsi, a second of Babur's sisters, Yadgar Sultan Begim, the ten-year-old daughter of the concubine Agha Sultan, "fell to Hamza Sultan's son Abdul Latif Sultan."136 She eventually was able to rejoin Babur when he took Hissar from the Uzbeks, and later joined her brother in India. During that same period yet a third of Babur's sisters, Ruqqaya Sultan Begim, daughter of Makhdum Sultan Begim (known as Qara Goz Begim) "fell to Jani Beg Sultan,” with whom she had two or three sons, although they all died young. ${ }^{137}$ In the invasion of Harat, the eyewitness, Khwandamir, wrote of Khanzada Khanim, daughter of Ahmad Khan, being married to Muhammad Khan of the victorious Uzbeks. In this case there is a suggestion that the woman approved of her new husband, although Babur remarks with disgust that the couple did not "wait for the prescribed interval to elapse,"138 and the Mughal scholar Beveridge calls the marriage illegal. ${ }^{139}$ Shibani killed five of Sultan Mahmud's six sons but all of the daughters were kept alive, "because of their value as wives."140

${ }^{133}$ Ibid., BA, p. 223- 24.

${ }^{134}$ Ibid., BA, p. 289.

${ }^{135}$ Mirza Haydar Dughlat, Tarikh, p. 116. Humayunnama, BA, p. 236.

${ }^{136}$ Humayunnama, BA, p. 294.

${ }^{137}$ Baburnama, Mano, p. 14. Humayunnama, BA, p. 275.

${ }^{138}$ Baburnama, Mano, p. 323. Thackston, tr., p. 435.

${ }^{139}$ Humayunnama, p. 31, BA, p. 252.

${ }^{140}$ Humayunnama, BA, p. 290. 
In the midst of Harat's pillage, Mihrangaz Begim, daughter of Muzaffar Husayn Mirza, was married off to Ubaydullah Sultan, after which the rest of the royal harem was sent back to Harat, where they were subsequently robbed of their jewels. ${ }^{141}$ Between attacks on Harat's forts, Kabuli Begim was “given in marriage to Qambar Mirza Kukaltash and Temur Sultan took Andalib into his harem." ${ }^{\text {142 }}$ Although not forced to marry an Uzbek husband, Khadija Begim, who had begun as a slave in the household of Sultan Abu Sa id Mirza before becoming the influential wife of Sultan Husayn Bayqara and raised to the rank of begim, was turned over by the victorious Shibani Khan to the wife of her enemy, "and he let her torment her in all sorts of ways."143

It is impossible to judge how many Timurid-Chaghatay noblewomen were actually forced into Uzbek conquest marriages. In the case of Khanzada Khanim of Harat, Khwandamir describes an actual "proposal" followed by the lady's acceptance and even her assurance, with witnesses, that she had been legally divorced two years earlier from her first husband Muzaffar Mirza Bayqara. ${ }^{144}$ This cannot have been the case for many of the women, however. The sources take on an undeniably bleak tone in referring to these marriages; there is no mention of celebratory wedding parties. If, for example, Babur's elder sister Khanzada had approved of her own marriage to Shibani Khan, surely Babur would have been quick to acknowledge that fact in defense of his own reputation. Many fled into Mughulistan, Badakhshan, Iran and Ottoman Anatolia. Among the women who managed to escape the Uzbek taking of Samarqand, a few managed to flee to Babur in Ghari There he was joined by 20, 000 soldiers led by "good and

\footnotetext{
${ }^{141}$ Khwandamir, Habib al-Siyar, Thackston, CP, p. 232. See also Humayunnama, BA, p. 263.

${ }^{142}$ Humayunnama, BA, p. 234.

${ }^{143}$ Baburnama, Mano, p. 322-3. Thackston, tr., p. 435.
} 
experienced commanders" who had previously been attached to Babur's enemy

Khusrawshah, who had "run off pell- mell" from the Uzbek attack on Hissar. ${ }^{145}$ Leading this newly acquired but substantial army, Babur headed to Kabul, which he had taken in 1504 and continued to hold as the seat of his power for the next twenty years.

\section{Babur's Kingdom}

In time many more refugees would find safe haven in Babur's outpost at Kabul, a trade center for goods from Khurasan, Iraq and Anatolia and "the principal trade depot for Hindustan."146 The safety of the Timurid refugees was limited, however, by the kingdom's small size and poverty and its precarious position on the borders of Uzbek, Safavid and Afghan territory. Yet there was stability there, and some comfort; Babur's days of roving brigandage were essentially over and it was in Kabul that he declared himself "padshah." There were parties in the green hills around the city, in the Timurid gardens planted not just by his ancestors but by also by Babur himself, who had inherited a love of gardens which would last his lifetime and mark all of his imperial possessions. In Kabul Babur discovered the pleasures of alcohol and drug use; he wrote a great many poems, composed his memoirs and fathered his children, including his first son, the future emperor Humayun.

In the Timurid manner, Babur carefully shared out the territory amongst the numerous Timurid refugees: "The areas outside of Kabul were divided among the princes and all the guest begs.... Villages and fiefs were given to some of the begs and warriors

\footnotetext{
${ }^{144}$ Ibid., Mano, p. 323. See also Humayunnama, BA, p. 252.

${ }^{145}$ Mirza Haydar Dughlat, Tarikh, p. 105.

${ }^{146}$ Baburnama, Mano, p. 199.
} 
who had been with me during some of our rencontres."147 Yet there was dissatisfaction expressed amongst those who felt they had received too little, and Babur was reproached for giving most of the lands to old retainers and those from his home province of Andijan. A "petty little province" insufficient to support a large population, Kabul could least of all easily welcome these displaced royals who had once enjoyed the pleasures of wealthy and voluptuous court life in Transoxiana's glittering capitals. ${ }^{148}$ Babur wrote, "Many tribes and clans had come to Kabul from Samarqand, Hissar and Khonduz. Kabul is poor; moreover it is a military place, not a civilian city, and could not supply money to all of these people. However it was deemed wise to give some grain to the families of each of these tribes and clans and then ride out on forays." ${ }^{149}$ He stripped the provinces of Kabul and Ghazni of their grain and imposed a tribute of goats and sheep, for which he later expressed regret. Although he held the title of padshah, Babur found himself supporting his people through constant raids, chapquns, ${ }^{150}$ into the territories of the Turcoman Hazaras, the Afghans and, eventually, Hindustan.

Babur was too ambitious to remain for long in a small, somewhat insignificant province, and although he was comfortably enjoying his role as padshah of Kabul, the presence nearby of his Uzbek nemesis made for constant tension, pushing Babur to further conquest. "A foreign people like the Uzbeks and an old enemy like Shibani Khan had overrun the territory held by Timur Beg's descendants.... Only I was left in Kabul. The enemy was very powerful (dushman bisyar quvi) and we were quite weak (kup za $\left.{ }^{\prime} i f\right)$.

\footnotetext{
${ }^{147}$ Ibid., Mano, p. 222-3. Thackston, tr., p. 298-9.

148 Ibid., Mano, p. 198.

149 Ibid., Mano, p. 223. Thackston, tr., p. 299.

${ }^{150}$ According to Stephen Dale, the chapqun raids employed by Babur had a "dual purpose, pacification and plunder," Dale, Garden, p. 195.
} 
At this point there was no way we could move far enough away from so powerful an enemy. We would have to move into either Badakhshan or Hindustan (ya badakhshan janibi ya Hindustan sari 'azm qilmaq kirak.).",151

Shortly after learning of Shibani Khan's death, Babur, whose sense of dynastic destiny constantly drove him to greater conquest, made one last attempt to retake the ancestral homeland of Mawarannahr. Allying with the messianic Shi' i leader Shah Ismail, founder of Iran's Safavid dynasty, in exchange for whose support Babur claimed allegiance to Twelver Shi ism, Babur took Samarqand for a third time. Yet in subsequent battles with the Uzbek forces in Bukhara and Tashkent, Babur's forces were routed and although he returned briefly to Samarqand he was forced again to abandon the ancestral throne (and with it, the Shi $i$ affiliation). Babur was never again able to march his armies north of the Oxus River, and "leaving Samarqand and Mawarannahr to the Uzbeks and the revanchist nostalgia of his descendants," he returned to Kabul in $1514 .{ }^{152}$

Yet, ever ambitious in the interests of empire $\left(\right.$ mulkgirliq $\left.^{153}\right)$ and Timurid dynastic continuity, Babur began raiding across the Indus River by 1519, taking Lahore by 1523 . Encouraged by his success in Lahore, Babur called to the Afghan king of Delhi and Agra, Sultan Ibrahim Lodi, to surrender the properties previously taken by Timur in 1398 . His demands were, unsurprisingly, rejected, which gave Babur the justification he desired. His success at the battle of Panipat in 1526 established Timurid rule in India as "an act of military imperialism legitimized by Timur's brief invasion." 154

151 Baburnama, Mano, p. 334.

152 Dale, Garden, p. 292.

${ }_{153}$ mulkgirliq: Babur's term, meaning the seizure of imperial territory

${ }^{154}$ Ibid. 
The wealth of India staggered Babur, who immediately gave the Lodi treasury away. Much of it went to his soldiers and companions but a large shipment of gifts was proudly sent off to the Timurid refugees waiting for news in Kabul: trays of jewels, dancing girls, golden ashrafis and silver shahrukhs, with individual gifts chosen by the king for each of the begims. ${ }^{155}$ He sent charitable donations to Samarqand, Khurasan, Kashgar, Iraq, Mecca and Medina, Karbala, Najaf and Mashhad, among other holy places, and his self- inflicted poverty brought him the affectionate nickname "Qalandar.",156

With a new capital city in Agra, with all the wealth and land available in vast India, Babur was finally able to preside over a recreated and renewed Timurid Empire. It was at this point that he requested, as his daughter later recalled, that the refugees from the Uzbek invasion of Mawarannahr come to his new imperial court. Just who was invited to participate in the re-establishment of Timurid glory is made very clear by the letter his daughter quotes: "All those attached to us shall receive our patronage, and most particularly those that had given service to our father, grandfather and forefathers.... And those who are of the lineage of Sahib Qiran and Chingiz Khan, let them set out for our court." ${ }^{\prime 157}$ Many of the displaced Timurids had been dispersed in other directions, into Mughulistan or into Safavid and Ottoman territory, but a large number managed to reach Babur's refuge.

\footnotetext{
${ }^{155}$ Humayunnama, pp. 12-13.

${ }^{156}$ Muhammad Kasim Ferishta, History of the Rise of Mahomedan Power in India, John Briggs, tr., Calcutta: Editions Indian, 1829, reprints 1908, 1966, II, p. 31. The reference is to the highly itinerant ascetic dervish order known as the qalandaris.

${ }^{157}$ Humayunnama, pp. 13-4.
} 
Of the one hundred and forty- five fighting noblemen who are listed as having served under Babur, thirty- three were Indian nobles who joined him after his success against the Lodi dynasty and several more were Afghans of temporary allegiance; they all melted away during Humayun's interregnum. Of the remainder, fifty- two are easily identified as Timurid and Chaghatay military men, including some of Babur's original supporters from the Ferghana Valley and a number of Khurasanis who had formerly allied with the Bayqara line in Harat, including Sultan Junid Barlas, Yunus Ali, Hasan Ali Julayir and Qasim Husayn Shibani. ${ }^{158}$ There were also a number of Uzbek fighters, including several sons of mixed Timurid-Uzbek marriages, such as the two sons of Sultan Husayn Bayqara's daughter, Aysha Sultan Begim Bayqara; Qasim Husayn Sultan Uzbek became an amir of Babur and his sons Humayun and Abdullah Sultan Uzbek served under Babur. ${ }^{159}$ The remainder was a mixed lot; adventurous Turcomans and even a few Ottoman Turks from whom Babur received his small but significant artillery.

Other than fighting men, scholars and religious men joined Babur's court. Poets and artists from the Bayqara court in Harat may have joined Babur, although very few are mentioned in the record. Among them, the famed scholar and historian Ghiyas al-Din Muhammad Khwandamir, who had written histories under the patronage of Sultan Husayn Mirza and later served as sadr for Badi al-Zaman Mirza, heeded Babur's call and set out for the Timurid court in India, arriving in Agra in 1528 after an arduous journey of seven months. ${ }^{160}$

\footnotetext{
${ }^{158}$ Iqtidar Alam Khan, The Political Biography of A Mughal Noble, New Delhi: Munshiram Manoharlal Publishers, 1973, p. X.

${ }^{159}$ Humayunnama, BA, p. 209.

${ }^{160}$ Ghiyas al-Din Muhammad Khwandamir, Qanun-i Humayuni, ed. M. Hidayat Hosain, Calcutta, 1940, preface. Khwandamir originally chose to remain in Harat after the Uzbek conquest, even carrying a
} 
Celebrating his victories, Babur feasted in Agra with the Naqshbandi spiritual elite represented by Khwaja Abdul Shahid and Khwaja Kalan, Ahrar's grandsons, seated at his right hand. As padshah of Kabul, Babur had "inherited" the local Naqshbandi Sufi community, whose extensive local properties adjoined the royal demesne in an indication of their close relationship with the previous rulers of Kabul. ${ }^{161}$ Accumulated under the sponsorship of devoted Timurid rulers, these waqf properties offered a crucial base from which the Naqshbandi order would, in concert with Babur, launch their own expansion into northern India. ${ }^{162}$ Until the mid- seventeenth century, their base in Kabul would remain the most important center of the Naqshbandi order, anchoring their vital KabulAgra axis within Babur's Timurid Empire. ${ }^{163}$

The Timurid refugee community in Agra included seven of Babur's paternal aunts, the daughters of Sultan Abu Sa'id Mirza (1424- 1469), including Gauhar Shad Begim who was a celebrant at Humayun's accessional feast in Agra in 1531 as well as Fakhr Jahan Begim, who went to India in 1526 and was at Humayun's feast in Agra in 1531 along with her daughter, Kichak Begim. Khadija Sultan Begim's circumstances are unclear; as a wife of Sultan Husayn Mirza, she was, as noted, enslaved by Shibani Khan on the conquest of Harat, but the sources place her in India with her sister, Fakhr Jahan Begim, in 1526. Badi al-Jamal Begim was in India during Babur's lifetime and was a guest at Humayun's feast in 1531 in Agra. Aq Begim Miranshahi came to India at

petition, under great duress, from the remaining residents of the city to Shibani Khan. Eventually, after serving various surviving Timurid patrons in Khurasan and the Safavid Shah Ismail, who had conquered the region from the Uzbeks in 1510, Khwandamir left for India in 1527. He remained closely affiliated with the Timurid court of India for the remainder of his life, dying while in the service of Humayun in 1535. His most noted works include the Habib al-Siyar, which includes a rare first-hand account of the fall of Harat, and the Qanun-i Humayun, an enthusiastic panegyric devoted to Babur's successor, Humayun.

${ }^{161}$ Dale and Payind, p. 223.

${ }^{162}$ Ibid. 
Babur's invitation in 1528 and seems to have remained, for she was at Humayun's feast in 1531. Bakht Sultan Begim came to India at Babur's request shortly after his conquest accompanied by her daughter, Afaq Begim, who arrived in Agra in 1528. Also in India by 1531 was Agha Sultan Aghacha, a wife of Umar Shaykh Mirza and mother of Babur's half-sister Yadgar Sultan Begim. Yet a final aunt of Babur, and daughter of Abu Sa'id, Payanda Sultan Begim Miranshahi, fled to Iraq at the time of the Uzbek invasion of Khurasan and "died there in distress."164 The daughters of Babur's Chaghatay maternal uncles, Zaynab Sultan Khanim and Muhibb Sultan Khanim, also came to his court in India.

Babur's beloved elder sister, Khanzada Begim, who had been left as ransom in Samarqand and married to Shibani Khan, soon after had a son by him, Khurram Shah, who died young. Shibani divorced her after several years and gave her in marriage to a follower, Sayyid Hada, who died in 1510 at the battle of Merv. A year later Khanzada Begim, now aged thirty- three, was returned to Babur by the Safavid Shah Ismail, victor at the battle of Merv in which Shibani Khan was killed. ${ }^{165}$ She later married Mahdi Muhammad Khwaja, who had been with Babur since at least 1519. Khanzada Begim died at age sixty-seven in Qabal- Chak in $1545 .^{166}$

Mihrangaz Begim, who had been forced into marriage with an Uzbek warrior, Ubaydullah, at the conquest of Harat, arrived in India by 1531 and attended Humayun's

\footnotetext{
${ }^{163}$ Ibid., p. 224.

${ }^{164}$ Humayunnama, BA, p. 271.

${ }^{165}$ Mirza Haydar Dughlat, Tarikh, p. 159.

${ }^{166}$ Humayunnama, BA, pp. 250-1. Beveridge suggests that perhaps Khanzada had been married to Mahdi prior to her marriage to Shibani Khan, but that the divorce from her first husband was part of the arrangement with the Uzbek chieftain.
} 
feast with a female cousin, Shad Begim. ${ }^{167}$ Afaq Begim, a wife of Sultan Husayn Mirza, never made it to India, but died in Babur's Kabul in 1527 or 1528. Sultanum Begim Bayqara, eldest daughter of Sultan Husayn Mirza Bayqara, fled Harat for Khwarazm in 1507 , eventually making her way to Kabul by 1519 , where Babur showed her great respect and gave her the gift of a garden, the Bagh-i Khilwat (Garden of Retirement). She died at the Indus River while traveling to Babur's court in Agra in $1527 .{ }^{168}$ Another of Bayqara's daughters, Ayisha Sultan Begim Bayqara, had been married successively to two Uzbek nobles, by each of whom she had sons who eventually joined Babur's service in India. She was in India by 1531, and died in the battle of Chausa in 1539. A few half sisters of Babur were noted in India by 1535: Mihr Banu Begim and Yadgar Sultan Begim, who had been a captive of the Uzbeks as a child. Even Babur's first wife, a daughter of Sultan Ahmad Mirza Miranshahi, was reported at the neo- Timurid court in India in 1535, although she had divorced Babur thirty- two years earlier, in $1503 !^{169}$ Apart from women of royal lineage, family retainers are counted as among the earliest of refugee Timurids at Babur's court in Agra. Listed as honored guests at various royal banquets, their position within the family seems to reflect a high degree of respect for long years of loyal service and their willingness to immigrate to India amongst the Timurid exodus. Attending the Mystic Feast honoring Humayun's accession to the Mughal throne on the anniversary of his father's death was Bachaka Khalifa, a "head woman- servant" of Babur's household, one of only two women who escaped Samarqand with him and his mother as they fled the Uzbek invaders in 1501. She was killed in India

${ }^{167}$ Humayunnama, BA, p. 263.

${ }^{168}$ Humayunnama, BA, p. 287.

${ }^{169}$ Humayunnama, BA, p. 209. 
at the battle of Chausa in 1539. ${ }^{170}$ The second woman was an Atun Mama, or tutor for girls, referred to only by her title, who had been in the retinue of Babur's mother, Qutluq Nigar Khanim. Left behind in Samarqand at the time of the Uzbek conquest, she traveled on foot to Pashgar to rejoin Babur in 1501 and seems to have remained with him thereafter.

These, then, were the individuals who found refuge in the vast, wealthy territory newly conquered by the last independent Timurid prince: Timurid Turk and Mongol military men, royal princes and princesses of Mawarannahr and Khurasan, along with a few stray adventurers, at least one historian, poets and artists, religious leaders, tutors and serving women. Most were refugees and all were welcomed by Babur, who opened wide the gates of his new capital and declared his establishment of a new Timurid kingdom on the Indian subcontinent. The character of Babur's kingdom would develop directly out of the cultural personality of this founding community. Their passion for the Timurid past and their commitment to a re-creation of Timurid courtly culture on the Indian subcontinent would forever affect their ability to adapt and accept local customs, and derive new understandings of culture, family relationships, politics, religion and law under the influence of their new frontiers. It was not simply Babur, founding father of the Mughal Empire, who insisted on the Timurid character of his new imperium, but an entire community of refugees. They mourned their losses as a group and proceeded to define and orient the Mughal imperial court in India, affirming identity and legitimacy in a process involving the continued development of potent symbols of power and royalty.

\footnotetext{
${ }^{170}$ Ibid, BA, p. 212. This woman's identity is not entirely definite but Beveridge makes the connection among the "Bachaka" who escaped with Babur's household, the "Bachaka" listed as a guest at the Mystic
} 
Babur's death in 1530, only four years after his conquest of the Lodi kingdom of Delhi and Agra, was a blow to the refugee community he had sponsored. His daughter remembered, "Black fell the day for children and kinfolk and all. They wailed and lamented." Anxious to avoid instability and anarchy in Babur's absence-- the "terrifying void" felt by their predecessors at the death of Timur-- his amirs avoided announcing the death, instead suggesting to the anxious public that Babur had chosen the life of a dervish, handing over the reins of office to his eldest son, Humayun (r. 1530- 1556). "People were at once reassured by the proclamation." 171

Humayun had been born in Timurid Kabul and, in the classic Turco- Mongol tradition, his young adulthood was spent in close association with his father, as a military commander and governor of various conquered territories. At the time of his accession to the throne, Humayun was a well-known figure within the Timurid refugee community, and his succession was generally accepted with good grace. ${ }^{172}$ Most importantly, as emperor, Humayun immediately acted to establish his own personal commitment to the Timurid émigrés, visiting the various households where "he made inquiry after their health and offered sympathy and spoke with kindness and commiseration.” $\mathrm{He}$ reaffirmed Babur's distribution of lands and property, confirmed positions and offices and assured the refugees that all would remain as before. ${ }^{173}$ His sister, Gulbadan Begim, later wrote, "During the ten years after the death of hazrat Firdaus Makani [Babur] that hazaet Jannat Ashyani [Humayun] was in Hind, all the people lived in tranquility and

Feast, and a third "Bachaka" who was lost in Shir Khan's rout of Humayun at Chausa in 1539, a battle in which many of these Timurid women and children were killed or captured.

${ }^{171}$ Humayunnama, p. 20.

${ }^{172}$ For a more thorough discussion of the succession crises which followed see below, chapter five.

${ }^{173}$ Humayunnama. p. 25. 
safety, and obedience and reverence." ${ }^{174}$ Given the degree of upheaval in India during Humayun's reign, Gulbadan Begim's reference to "all the people" cannot be taken to refer to the population of northern India but rather the extended émigré Timurid family.

Marking the transition to new leadership, so soon after arriving in their conquest territories, the fledgling Timurid community in India and Kabul united in a series of formally sanctioned gatherings which can only have enhanced their consciousness of community and survival. Gulbadan Begim writes of enthronement festivities that lasted several days, organized by Humayun's mother, Maham Begim, who had married Babur in 1506, after his visit to Harat. The bazaars of Agra were illuminated and massive pavilions were erected of European brocade with gilded tent poles. Maham Begim, as queen mother, was said to have distributed special robes of honor to seven thousand people, perhaps an exaggerated number but evidence of a great many guests. ${ }^{175}$ On the anniversary of Humayun's accession, Khanzada Begim called together the TimuridMughal royal elite for a magnificent gathering known as the "Mystic Feast" (tuy-i tilisim) for its lavish setting within the octagonal Talismanic Palace (tilisim-i nihad or 'imarat- $i$ tilisim) built by Humayun on the Jamuna River. ${ }^{176}$ A few years later a similar celebration was held to mark Mirza Hindal's wedding, and the guests included eightyseven Timurid family members, many arriving from Kabul to join those who had already

\footnotetext{
${ }^{174}$ Ibid., p. 26. The Timurid- Mughals gave their rulers posthumous titles in addition to their given names, regnal titles and honorifics. Firdaus Makani was the name given to Babur, meaning "whose place is paradise," and Jannat Ashyani was the posthumous title given to Humayun, meaning "who is nested in the garden of paradise." In an unrelated note, Gulbadan's editor, A. Beveridge affirms that Humayun remained in India not for ten but for only about nine years before being driven out by the Afghans and forced into his own interregnum.

${ }^{175}$ Ibid., p. 28.

${ }^{176}$ Gulbadan Begim uses the former term in Humayunnama, p.30, whereas Khwandamir's discussion of the Mystic Feast in the Qanun-i Humayun, p. 140, uses the latter term.
} 
made the permanent move to India, as well as "other begas and aghas, the wives of the military commanders."

Their participation in these lavish celebrations may have had as much to do with acknowledging and celebrating their survival as a group as with commemorating a peaceful political succession, rare though that was in the Timurid experience. These splendid imperial gatherings reinforced and enhanced the Timurid refugees' awareness of their common identity, affirmed their group solidarity and bound then together as a unit. The sudden loss of Babur, who had been the principal driving force ensuring Timurid survival, did not bring about the end of the new Timurid Empire nor reverse commitment to Timurid court identity in India. They would know a great deal of uncertainty and loss in the future, but the identity of the émigrés had been affirmed and established, even enhanced by their shared loss and the survival of Timurid ideals of self and culture.

${ }^{177}$ Humayunnama, p. 33. 


\section{CHAPTER 3}

\section{DEVELOPMENT OF THE MUGHAL IMPERIAL IDENTITY}

\section{Genealogy and the Guregeniyya}

The power of a prestigious genealogy in the establishment of dynastic political rights lay in "attention to lineages as more than family trees; they also become resources for mobilization and engagement in the present." ${ }^{178}$ Timur's own genealogical claims were modest; his attachment to the Chingizid lineage through marriage was a critical factor in the establishment of legitimacy, his own and that of his sons. The overwhelming and indisputable fact of his military success, however, not only diminished the necessity of a borrowed form of legitimacy but also allowed and encouraged his biographers to extol Timur's own antecedents. The fifteenth-century historian Dawlatshah explains that "genealogists of the Turks say that Amir Timur Guregen's line and that of Genghis Khan met in Alanqua Khatun... and from her sprang this noble family." 179 By the time of the late Timurids, the person of Timur had been so exalted, in part by the various histories of his reign solicited by his heirs, that the Timurid- Mughal historian Khwandamir could pretend to ignore the added value of a noble lineage, writing, “the Sahib Qiran's person is so noble, his magnificence so great and his ambition

\footnotetext{
${ }^{178}$ Arthur F. Buehler, Sufi Heirs of the Prophet: The Indian Naqshbandiyya and the Rise of the Mediating Sufi Saint, Columbia: University of South Carolina Press, 1998, p. 107.

${ }^{179}$ Mir Dawlatshah Samarqandi, "Tadhkirat al-shu'ara," in Thackston, CP, p. 15.
} 
so exalted that there is no necessity to recount his noble forefathers' excellences or to publish his mighty ancestors' virtues." Khwandamir follows this statement, however, with an explicit rendering of Timur's lineage back to the Mongol mother goddess Alanqua and beyond, to Japheth, the son of Noah. ${ }^{180}$ As had occurred with Chingiz Khan, Timur's own lineage became sacralized, imbuing his descendants with political authority and cultural prestige.

Nearly universal acknowledgment of the power of Timurid dynastic legitimacy in the mobilization of contemporary political aims led rival kingdoms to link their own political pretensions to the Timurid dynasty, even long after the Timurid princes had been driven from Mawarannahr and Khurasan. In the case of Iran the transformation of Safavid political realities during the reign of Shah Abbas (r.1588-1629), due in part to the destruction of the Turcoman ascendancy and the rise of the ulama at court required adjustments to Safavid legitimizing principles. In recognition of the power of Timurid connections and in an attempt to bolster Safavid political ambitions, elaborate backstories were concocted, one of which claimed a fifteenth-century visit by Timur to the Safaviyya tariqat in Ardabil where he was said to have foreseen the rise of the Safavid dynasty. ${ }^{181}$ A waqf document describing an endowment by Timur in the name of the Safavid family is considered to have been forged in the court ateliers of Shah Abbas, who sent a copy of the document to the Mughal emperor Jahangir (r.1605-1627) in order to emphasize the historical connection between the Timurid and Safavid houses. ${ }^{182}$

\footnotetext{
${ }^{180}$ Khwandamir, "Habib al- Siyar," in Thackston, CP, p. 101.

${ }^{181}$ Sholeh Quinn, Historical Writing During the Reign of Shah Abbas I, Salt Lake City: University of Utah Press, 2000.

182 Ibid., p. 89.
} 
By the fourteenth century the Ottoman sultans had begun to prop up their own political legitimacy with the development of a central religious ideology and a flirtation with various origin myths which included elements of a charismatic genealogy. All the same, as late as the sixteenth century, the Ottoman bureaucrat and historian Mustafa Ali (1541-1600) wrote of the comparatively potent quality of Chingizid- Timurid genealogical authority. ${ }^{183}$ His detailed discussion of the topic bespeaks a general awareness, at least among Ottoman bureaucrats and literati, of the Turco- Mongol political tradition, coupled with a defensive acceptance of the comparative weakness of Ottoman legitimizing claims. Ottoman sensitivity to the dynasty's lack of a charismatic lineage had inspired a variety of strategies to bolster genealogical and religious ideology, but addressing the Ottoman Sultan Bayezid's crushing defeat at the hands of Timur at the battle of Ankara in 1402, Mustafa Ali asserts provocatively that the title Sahib Qiran (Lord of the Auspicious Conjunction) gave Timur's rulership universal implications, thus rendering him "superior in status to the Sultan of Rum." Not content to simply position Ottoman origins in the general Turco- Mongol milieu, however, Mustafa Ali eventually appropriated the more powerful genealogy, portraying the Ottomans as derived specifically from the Chingizid- Timurid line of world conquerors:

The Timurid dynasty and Chingizid House, those sharp- headed plunderers, Have all been described in this volume, From the start of the story to its end; From this garden, like a moist blossom, Bloomed those praiseworthy ones who are the Ottoman House. ${ }^{184}$

\footnotetext{
${ }^{183}$ Cornell Fleischer, Bureaucrat and Intellectual in the Ottoman Empire: The Historian Mustafa Ali (1541- 1600), Princeton, NJ: Princeton University Press, 1986, pp. $284-5$.

${ }^{184}$ Ibid., p. 278.
} 
As late as the eighteenth century, Nadir Shah, the Turkmen conqueror of Iran (r. 1736- 47) who sacked Mughal Delhi, attached his own political legitimacy to the still charismatic Amir Timur. He claimed to have found the famed treasure of Timur while on a hunting expedition, along with an inscription that predicted his meteoric rise to power. ${ }^{185}$

In India, in the near absence of Timurid rivals, Babur's descendants were able to transform loyalty from the personal to the imperial, and yet the very foundation of Mughal imperial identity continued to be constructed and transmitted through the dynasty's charismatic Timurid genealogy. As the last independent princes of the House of Timur, the Mughals self- consciously derived invaluable political capital from their lineage, and Mughal nurturing of Timurid cultural and political institutions can be attributed to their value as representations of the charismatic genealogy of the Timurid dynasty. Mughal attentiveness to Timurid ancestry was in large part devoted to serving an agenda of political legitimation. Unwavering loyalty to their Turco- Mongol/ Timurid political legacy remained a central legitimizing feature of rule for the Muslim dynasts of the subcontinent, sanctioning their power and justifying their success. Babur's own obsession with his Timurid heritage, and that of the founding generation of Timurid refugees, became a large part of the Mughal imperial self- image, insuring Mughal retention of Timurid values.

\footnotetext{
${ }^{185}$ Peter Avery, "Nadir Shah and the Afsharid Legacy," in The Cambridge History of Iran, Peter Avery, Gavin Hambly and Charles Melville, eds., VII, " Nadir Shah to the Islamic Republic," Cambridge: Cambridge University Press, 1991, p. 10. See also Thomas Allsen, The Royal Hunt in Eurasian History, Philadelphia, PA: University of Pennsylvania Press, 2006.
} 
Timur's descendants in India never referred to themselves as Mughals, itself an Arabized Persian word for Mongol. ${ }^{186}$ Although Babur's mother was a Chaghatay Mongol, daughter of the khan of Mughulistan, Babur and his companions identified themselves as Timurid Turks. Babur envied the lineage of Sultan Husayn Bayqara, noting that both his mother, Firuza Begim, and father, Mansur, made him "a grandson of Timur Beg's grandson Sultan Husayn and of Miranshah Mirza. He was, therefore, noble on both sides—a king born" (karimu'l tarafain idi-- asil badshah idi) ${ }^{187}$ It is interesting to note that Babur suggests a greater degree of royal charisma in the pure Timurid line, dismissing the superior qualities of a Chingizid genealogy, and this in dramatic contrast to his Timurid ancestors and their loyal allegiance to Chingizid royal bloodlines. ${ }^{188}$ For the more than two hundred and fifty years of their rule the Mughals referred to themselves as Silsilah-i Guregen or Guregeniyya, the dynasty of the son-in-law, retaining Timur's choice of imperial title as husband to a princess in the line of Chingiz Khan, for their imperial dynasty in India.

\footnotetext{
${ }^{186}$ Wheeler Thackston suggests that the term "Mughal" was "a misnomer picked up in the sixteenth century by Europeans, mainly the Portuguese, from a local usage, probably derogatory." As an example of the difficulties involved in determining an ethnic identity in sixteenth century Central Asia, Thackston also asserts that even Babur's mother (the daughter of Ulus Khan (d. 1487), who is generally considered to have descended directly from Chaghatay, son of Chingiz Khan, was not truly Mongol but that her people were "highly Mongolianized Turks." See The Jahangirnama, Memoirs of Jahangir, Emperor of India. Wheeler M.Thackston, tr. New York: Oxford University Press, in association with the Freer Gallery of Art and the Arthur Sackler Gallery, Smithsonian Institution, Washington, D.C. 1999, editor's preface, p. xxiii. See also Jahangir, Jahangirnama (Tuzuk-i Jahangiri), Tehran: Buny adi Farhangi Iran, 1359 (1980). All translations the author's unless noted.

For the purposes of this study, although it is historically inaccurate, I use the term Mughal or TimuridMughal to describe the Timurids of India for the sake of clarity and ease of understanding.

${ }^{187}$ Baburnama, Mano, p. 253. Thackston, p. 338.

${ }^{188}$ It has been noted that Babur's emphasis on Timurid genealogy may have been in part due to the pure Chingizid descent of his arch- rivals, the Uzbeks, through Chingiz Khan's son Jochi and through marriage with women from the lineage of Chingiz Khan's son Chaghatay. See Maria Eva Subtelny, "Art and Politics," pp.131-2.
} 
Timur's ceremonial title, Sahib Qiran, also came to be adopted as an important dynastic reference by the Mughal kings. Originating in pre- Islamic Iran among the Sassanids, the title retained universal applications and implications of supernatural legitimation. In Timur's own time the title had offered him an opportunity to circumvent political dependence on what was in fact a weak lineage, describing instead a degree of nobility beyond that of mundane earthly parentage. His panegyrists wrote, "A hundred centuries of time go by before fortune hands the reins of rule to a lord of the conjunction like you," and, "The learned and historians are agreed that in the time of Islam, nay from Adam's era until this very moment, no lord of the conjunction of Solomonic power like Amir Timur Kuragan [Guregen] has set foot from the abyss of nonexistence into the world of being." 189 The title was used regularly to reference Timur, in support of or even replacing other titles, and came to be so powerfully identified with him that even sixteenth-century Ottoman courtiers could argue the political implications of Timur's title versus the pretensions to genealogical legitimacy of the Ottoman sultans.

The title remained a posthumous regnal name for the Amir Timur, manipulated by future generations anxious to invoke the ancestor through whom their dynastic political legitimacy had its origins. On his accession to the throne in 1605, Babur's greatgrandson Jahangir expressed deepest pleasure with the chronogram composed by the courtier Maktub Khan, which described the new emperor as a second Sahib Qiran:

${ }^{189}$ Dawlatshah, "Tadhkirat al- shu'ara,” CP, p.15. 
King of kings Jahangir, a second Timur

Sat in justice on the victorious throne

Success, fortune, victory, pomp and triumph

Are wrapped around him to serve with joy

This is the date of his accession,

When fortune puts its head at the feet of sahib qiran-i sani. ${ }^{190}$

Twenty- five years later, Jahangir's son, the fifth Mughal emperor, Shah Jahan (r. 16271659), who, unlike Timur, was actually born under the conjunction of the planets Jupiter and Venus, was inspired to permanently adopt Timur's title, inscribing Sahib qiran-i sani, "the second lord of the auspicious conjunction," on his coinage. ${ }^{191}$ When, in the last years of his reign, Shah Jahan was imprisoned by his rebellious sons, he appealed for help by demanding his courtiers "march against the two undutiful sons, to inflict upon them the due reward of their misconduct," carefully reminding them of his role not only as emperor but as the Sahib Qiran-i Sani. ${ }^{192}$ The spiritual guide of Dara Shikuh (16151659), a sixth-generation Mughal prince, affirmed the dynastic claim to the title by describing his patron in the same terms. "The first and second Sahib Qiran (sahib qiran-i awwal u sani), namely Amir Timur and Shah Jahan, are the kings of grandeur," he wrote, "while our Dara Shikuh is the Sahib Qiran of the heart (ma sahib qiran-i dil)."193

\footnotetext{
190 "Murtib" al-Assam Samarqandi, Conversations With Emperor Jahangir, Richard C. Foltz, trans., Mazda Publishers, 1998, p. 30. As explained in Thackston, Jahangirnama: "The letters in the words Sahib qiran-i sani (second Sahib Qiran) yield 1013. To this is added the first letter of iqbal (fortune's head) which has a numerical value of one, for the Hegira date of 1014,"(1605) p. 28.

${ }^{191}$ Dale, "The Legacy of the Timurids," p. 46.

${ }^{192}$ Muhammad Hashim Khafi Khan, Muntakhab'ul-Lubab Muhammad Shahi, cited in Elliot and Dowson (cited henceforth as E\&D), The History of India As Told By Its Own Historians, Delhi: Low Price Publications, $1^{\text {st }}$ pub. 1867- 77, reprints 1990, 1996, 2001, VII, p. 228.

${ }^{193}$ Sakinat ul-Awliya, Curzon Collection, No. 443, fol. 83b. Quoted in Majma' ul-Bahrain (The Mingling of Two Oceans) by Prince Muhammad Dara Shikuh, M. Mahfuz-ul-Haq, trans. and ed., Calcutta: The Asiatic Society, 1929, reprint 1982, p. 8. This statement was made by the Sufi shaykh who initiated Dara Shikuh into the Qadiri order in 1049 (AH).
} 
Illustrated genealogical scrolls, silsilahnamas, produced in the Mughal workshops demonstrated Mughal claims to legitimate descent from Timur, Chingiz Khan, and the mythical Turco-Mongol ancestress, Alanqua, through whose impregnation by a beam of light the Mongols claimed descent. ${ }^{194}$ Even silsilahnamas produced in the Ilkhanid period were, like dynastic portraits, at a much later date amended by Timurids to include later descendants of the House of Timur. ${ }^{195}$ For example, a Timurid silsilahnama, the Mu'izz al-Ansab (The Glorifier of Genealogies), which had been produced in 1426 by the descendants of Shahrukh, was extended in the early sixteenth century to include Badi' alZaman, the Timurid prince, son of Sultan Husayn Bayqara, forced to flee Khurasan by the invading Uzbeks. A version of the Mu'izz al-Ansab found its way into Mughal hands in India, where portraits were carefully added on every page to illustrate the manuscript. ${ }^{196}$

The Mughal obsession with Timurid genealogical scrolls was again displayed by the last Mughal emperor Bahadur Shah Zafar (r. 1837-58, d. 1862), in whose court ateliers a fully illustrated and versified silsilahnama was produced which detailed the family line from Timur to Bahadur Shah himself, with the fascinating inclusion of the Afghan Shir Shah, who drove Humayun out of northern India in 1540; the Persian Shah Tahmasp Safavi (r. 1524- 1576) and Nadir Shah, who had sacked Delhi a hundred years earlier. ${ }^{197}$ Even the Mughal imperial seal came to function as something of a public dynastic silsilahnama. Beginning in the reign of Akbar (r. 1556- 1605) and lasting

\footnotetext{
${ }^{194}$ Ibid.

${ }^{195}$ Ibid., p. 48.

${ }^{196}$ Eventually the Mughal manuscript made its way to London, where it currently resides in the British Library, MS. OR 467. A copy of the original Timurid manuscript, which never entered Mughal India, was carried to Istanbul and then to France, where it is housed in the national archives. It has no illustrations.
} 
through that of Aurangzeb (r. 1659-1707), the inscription on the Mughal seal articulated the Timurid genealogy of the Mughal royal family, while the tiny portraits of Jahangir which were distributed to his closest circle of supporters at court were "adorned with a genealogical tree" of the Timurid dynasty. ${ }^{198}$

\section{The Timurid Mythical Homeland}

Implanted as something of a cultural memory among Babur's descendants, Samarqand remained in the Mughal imagination a near- mythic ancestral land and Timur the dynastic patriarch. Babur's descendants compulsively reiterated imperial claims to Transoxiana, confirming Mughal loyalty to the concept of an ancestral homeland, the lost patrimony of Babur and the "hereditary dominions" of the Mughal kings. ${ }^{199}$ Babur himself had made three attempts to take and hold Samarqand, and when his son Humayun (1508-1556), with the aid of Safavid troops, returned from Iran to reclaim his patrimony, it was towards Samarqand that he first led his invading force. Only after being betrayed by his brother Kamran near Balkh in 1549 and having his army routed by the Uzbek forces did he reluctantly turn south to retake his lost empire in northern India. $^{200}$

Akbar's biography describes imperial plans for a reconquest of Transoxiana: "Should the wide country of India be civilized by means of his obedient vassals he [Akbar] would proceed to Turan... and would get possession of the lands of his ancestors. In this way the various classes of mankind would experience the joys of

\footnotetext{
${ }^{197}$ British Library, MS. OR182.

${ }_{198}$ Mirza Nathan, Baharistan-i Ghaybi, B. I. Borah, tr., (2 vols) 1936, I, pp. 17 and 74.

${ }^{199}$ Richard C. Foltz, Mughal India and Central Asia, Karachi: Oxford University Press, 1998, p.134.
} 
concord."201 Abu'1 Fazl affirms Akbar's interest, writing in 1587 that "his majesty has turned his attention to the conquest of Turan." ${ }^{, 202}$ The biographer removes any likelihood of a Mughal return to Transoxiana, however, by conceding that this expedition could only occur after Akbar's pacification of Hindustan and possession of the Deccan were complete. Yet Jahangir affirms his father's interest in the re-establishment of the Mughals in Transoxiana, declaring that "the conquest of Transoxiana was always in the pure mind of my father, although every time he determined on it things occurred to prevent it."203 He goes on to describe what would ultimately remain his own unfulfilled aspiration to leave his sons as governors of the subcontinent while he himself led his armies north: "As I had made up my mind to the conquest of Transoxiana, which was the hereditary kingdom of my ancestors, I desired to.... go myself with a valiant army in due array, with elephants of mountainous dignity and of lightning speed, and taking ample treasure with me, to undertake the conquest of my ancestral dominions."204 Jahangir's son, Shah Jahan (1592-1666), did at last organize a Mughal expedition to Mawarannahr, sending his sons and "an army of fifty thousand horse and ten thousand musketeers, rocketmen and gunners" north to conquer Balkh and Badakshan, which "were the hereditary territories of his House and the keys to the acquisition of Samarqand, the home and capital of his great ancestor, Timur Sahib Qiran." 205 He too was unable to hold the

\footnotetext{
${ }^{200}$ Humayunnama, pp. 88-9.

201 Abu'l Fazl, Akbarnama (henceforth cited as AN), Delhi: Low Price Publications, $1^{\text {st }}$ ed., 1902- 39, reprints 1989, 1993, 1998, 2002, III, p. 616.

${ }^{202}$ Riazul Islam, A Calendar of Documents on Indo- Persian Relations, Tehran, 1982, p. 207, in Mutribi alAsamm of Samarqand, Conversations With Emperor Jahangir, Richard C. Foltz, tr., Costa Mesa, CA:

Mazda Publishers, 1998, p. 8.

203 Jahangirnama, p. 16. Thackston, tr., p. 33.

${ }^{204}$ Ibid., pp. 16 and 53. Thackston, tr., pp. 33 and 68.

205 'Abdul Hamid Lahauri, Badshahnama, E \& D, Vol. VII, p.70.
} 
region, in part because of the overextension of Mughal forces, committed as they were to the simultaneous Mughal conquest of the Deccan.

Even amongst the Mughals Jahangir was remarkable for his relentless attention to his dynastic lineage and the maintenance of Timurid political and cultural continuities, regularly referring in his autobiography to Transoxiana (Turan) as his vilayet-i marusi, "hereditary territories" and mulk-i marusi, "ancestral domain."206 In the middle of Jahangir's twenty- two year reign (r. 1605- 1627) he made the lengthy nostalgic pilgrimage to Kabul, Babur's long-time capital, which he describes in his memoirs as “our home dominions."207 There, Jahangir traced Babur's footsteps, visited his favorite gardens and added his own name and that of their shared ancestor, Timur, to Babur's dynastic inscriptions. Visitors to Jahangir's court from Uzbek territory found themselves being intensively interviewed regarding former Timurid possessions in Mawarannahr. "First he asked me about the condition of the mausoleum of his majesty Timur... The emperor then asked about the color of Timur's [black jade] sepulcher."208 The visitor's detailed description of Timur's tomb earned him imperial gifts: a robe of honor, a “top quality turban, and Kashmiri shawl... a gold- embroidered robe, a sash with good golden thread," and a horse and saddle. ${ }^{209}$ Later, on the advice of his visitor, Jahangir set aside ten thousand rupees for "the shrine of our great honored ancestor... in order that that blessed station be maintained." ${ }^{210}$ Mughal imperial maintenance of Timur's mausoleum, the Gur-i Amir in Samarqand, would continue until the eighteenth century.

\footnotetext{
206 Jahangirnama, pp. 16 and 53.

207 Ibid.

208 "Murtib" al-Asamm Samarqandi, Conversations, pp. 22-3.

${ }^{209}$ Ibid., 24.

${ }^{210}$ Ibid., p. 87.
} 
Yet the Mughals also claimed the new imperial territories in India as a legitimate portion of their Timurid inheritance. Timur had conquered northern India in 1398, taking the plunder of his campaign (including artisans and elephants) back to Samarqand and leaving appointees to govern in his stead. At the time of Babur's incursions, the descendants of those Timurid governors were still in place in some regions, notably Bherah, Kushab, Chenab and Chiniot. ${ }^{211}$ On a raiding foray into India in 1519 Babur pulled back, preventing his men from pillaging Bherah by claiming, "These districts have long belonged to the Turk.... Our regard is upon this district and its people. There will be no sacking or plunder (talan u taraj)," and repeating later, "Since we regarded the territories occupied by the Turks as ours, there was no pillage or plunder.,"212 The decision to tax Bherah, a frontier district of the Lodi sultanate, rather than loot it, has been described as "the first phase of the foundation of the Timurid- Mughal empire of Delhi and Agra." ${ }^{213}$ It was as "presumptive sultan," a legitimate ruler in the direct line of descent from the conqueror Amir Timur Guregen that Babur petitioned the Lodi sultans to surrender authority over those territories that had in the past "been dependent on the Turk." ${ }^{214}$ Yet with the hot season upon them, Babur and his warriors returned to Kabul and the Lodi sultans immediately retook the "Timurid" territories claimed by Babur. It was not until 1525 that Babur returned, this time determined on conquest and the resumption of Timurid rule in India.

\footnotetext{
${ }^{211}$ Baburnama, Mano, p. 352.

${ }^{212}$ Ibid., Mano, pp. 352 and 357. Thackston, tr., pp. 476 and 480.

${ }^{213}$ Dale, Garden, p. 297.

${ }^{214}$ Ibid, pp. 297 and 299.
} 
The mythology of various ancestral homes developed in degrees and was expressed differently for those territories most valued yet permanently lost (Transoxiana), the region which established the House of Babur and formed the springboard for success and conquest (Kabul), and finally the vast but utterly foreign empire of India. Mughal feelings for India were mixed, as loyalty to the ancestral homeland of Mawarannahr and longing for Babur's beloved Kabul, and the initial dreadful shock of India's geography and climate, were balanced with the wealth and prestige of an outstanding Indian imperial success. Yet there was no doubt in the minds of Babur, his Timurid forces, or the Timurid refugee community and their descendants regarding the legitimacy of the Indian conquest; India had been Timurid territory for a hundred and twenty-five years; it was to be expected that the last independent Timurid prince would simply claim his rightful inheritance.

\section{The Use of Literature and Art in the Production of Identity in India}

The Mughals built their political legitimacy on regular references to their possession of an impeccable imperial lineage and affirmation of their territorial legacy. They reinforced this by modeling their imperial identity on the universally acclaimed attributes of their Timurid predecessors, those "social assumptions, political and cultural values... and even aesthetic standards" which had come to define the distinct and recognizable Timurid "cultural personality." For this reason, Persianate aesthetics dominated at the Mughal court and the Persian language nearly supplanted the use of Turki. ${ }^{215}$ In the highly competitive, fractured world of the Timurid princely successors,

\footnotetext{
${ }^{215}$ The use of Turki within the Guregen family in India remained a permanent fixture. See below.
} 
the Timurid dynastic identity and ruling ethos had come to be defined by unprecedented imperial patronage of arts and the wholesale adoption of the Persian literary tradition. There can be no question that the Mughal kings, themselves poets and painters, calligraphers and memoirists, had a deep and sincere appreciation for the arts. Yet the arts played a critical political role at the Timurid courts, affirming not only royal status but also the viability of individual rule. In developing their own legitimizing discourse, the Mughals retained the Timurid tradition of imperial patronage, through which, in the model of their ancestor Timur and his successors, they manipulated historiography, miniature painting, architecture and even landscape in order to emphasize the extent of their Timurid inheritance, reinforce political legitimacy and define their cultural personality as the ruling dynasty.

The arts of the book were used to particular effect in India, where the production of historical chronicles relentlessly affirmed the legitimacy of Mughal dynastic rule. As Timur and the Timurid princes had done before them, individual Mughal kings participated fully in the production of imperial narrative imagery, producing histories that were intended as personal justifications of their inheritance of the Timurid throne. Babur composed his own detailed and fascinating memoir, intended as a validation of his right to rule and as advice literature for his sons and future Timurid kings. Without indulging in a great deal of personal analysis, Babur narrated his exploits with remarkable honesty, expressing grandiose imperial ambitions alongside assertions of his personal legitimacy as a Timurid prince of impeccable lineage. Although the Baburnama was written in Babur's Afghan and Indian territories, it was composed in Turki rather than court 
Persian, an obvious indication that it was directed to a Central Asian constituency, the "legitimizing audience... comprised of the Islamized, literate, Turki- speaking Timurid and Chaghatay Mongol elite, and beyond them the broader society of Turco- Mongol military aristocrats. ${ }^{216}$ A copy of the memoirs was sent back to Kabul as early as 1529 , for it was primarily to the transitional post- Uzbek generation of Timurid refugeenobility that he hoped would coalesce around him, forming the crucial backbone of his new Timurid court, that Babur aimed his legitimizing text.

Babur's successor, Humayun retained the famed historian Ghiyas al-Din Khwandamir at his court, officially inviting him to compose a history of his rule. According to Khwandamir, Humayun explained his reasons, saying, "It seems proper and desirable that the inventions of my auspicious mind and the improvements of my enlightened understanding should be arranged in a series and written down in order that in future ages the light of these works may shine among the people of countries near and remote., $217^{217}$

Akbar, affirming the dynasty's imperial past and current legitimacy, requested that members of his court with personal memories of his father or grandfather that they record them. Babur's daughter, Gulbadan Begim, explained, “An order was issued, 'Write down whatever you know of the doings of Firdaus makani and Jannat ashyani [Babur and Humayun].' In obedience to the royal order, I set down whatever there is that I have heard and remember."218 It was at Akbar's court that Gulbadan Begim composed her memoir, the Humayunnama; Humayun's ewer-bearer, Mihtar Jauhar Aftabchi, who

\footnotetext{
${ }^{216}$ Dale, Garden, p. 41.

${ }^{217}$ Khwandamir, Habib al-Siyar, E\&D, V, p. 118.

${ }^{218}$ Humayunnama, p. 2, Bev., p. 84.
} 
had spent twenty years at the emperor's side, composed the Tazkiratu'l-waqi'at; and Bayezid Bayat wrote the Tarikh-i Humayun, covering the years 1542- 1591. In addition, Akbar commissioned dynastic histories such as the Chingiznama (History of Chinggis Khan), the Timurnama (History of Timur) and the Tarikh-i Alfi (History of a Thousand Years), which asserted the dynasty's Mongol and Timurid ancestry, claiming to have "inaugurated a new millennium" with the foundation of the South Asian Timurid empire. $^{219}$

Akbar is the best documented of all Mughal kings, due in large part to the six volumes of personal narrative, imperial encyclopedia and ideological underpinnings for Mughal, and more particularly Akbari rule, the Akbarnama and Ain-i Akbar, both written by Akbar's close friend and panegyrist, Abu'l Fazl. Abu'l Fazl exalted in Akbar's lineage, describing him as "the glory of the House of the Guregen" (furug-i khanadan- $i$ Guregeni), "the lamp of the illustrious house of Timur" (chirag-i dudman-i Sahib qirani), and "heir of Humayun's throne." 220 The entire first volume of Abu'l Fazl's study is devoted to establishing Akbar's dynastic and political legitimacy, beginning with detailed descriptions of his horoscope, cautiously delineated by Abu'l Fazl for every possible audience in the various Greek, Persian, Ilkhanid and Indian astrological traditions. ${ }^{221}$ In confirmation of the continued relevance of the Mughal dynasty's Mongol- Timurid genealogy, the remainder of the volume is devoted to Akbar's dynastic lineage, beginning

\footnotetext{
${ }^{219}$ Gülru Necipoğlu, "The Serial Portraits of Ottoman Sultans in Comparative Perspective," The Sultan's Portrait, Istanbul: Isbank, 2000, p. 51.

${ }^{220}$ Abu'l Fazl, AN, I, p. 17. In the same section, among other epithets, Abu'l Fazl describes Akbar as "heir apparent of the sun," "quintessence of the co-mingling of nights and days" and "the cheek mole of sovereignty and fortune."

${ }^{221}$ Ibid., Akbar's Greek horoscope, pp. 67- 84, Indian horoscope, pp. 85- 95, and discussion of the differences between them, pp. 119- 128. Akbar's Shirazi horoscope, pp. 96- 116, and Ilkhanid horoscope, pp. 117- 128
} 
with the original man, Adam, through Noah and his son Japheth, for as in Timur's later genealogical charts, "the Khans of the eastern cities and of Turkestan all derive from him."222 Nineteen generations later, the genealogy was strategically shifted to a Mongol daughter of the lineage, Alanqua, whose miraculous pregnancy by a beam of light resulted in the birth of three sons who would father the Mongol and Turkish nobility. Abu'l Fazl, who did not invent this dynastic lineage, was quick to defend the Mongol tradition of the chaste birth-- arguing against "scientific computations" in the place of "auspicious guidance," he reminded the reader that Adam was born of neither father nor mother, so "why not admit a child without the father? Especially... in the case of Jesus and Mary." Abu'l Fazl was not ignorant of the messianic implications when comparing the Mongol successors to Jesus, composing a simple verse: "If you believe the tale of Mary, believe the same of Alanqua."

A descendant of Alanqua, Qaculi Bahadur, was said to have had a miraculous dream in which a series of shining stars emerged from his breast, interpreted by his father to indicate "seven dominant descendants bearing on their brows the diadem of primacy and the crown of rule." An eighth star, which lighted the entire world and produced smaller stars which illuminated the universe, represented his eighth descendant, "who would exhibit world wide sovereignty." Although there were those who identified the first seven stars with the descendants of Qaculi Bahadur and the eighth star with Timur, Abu'l Fazl rejects this notion, arguing that non- ruling descendants could not be counted amongst the favored kings. Rather, in Abu'l Fazl's reckoning, the very first of the stars

\footnotetext{
${ }^{222}$ Ibid., I, p.167. Japheth, as "Father of Turk" (Abu'l-Turk), is also described as the original possessor of a rain stone (tr: yedatash, per: sang-i yada). Belief in a stone which could summon rain and control weather
} 
denoting kingship represents Timur, with his celestial descendants reaching the true culmination of the prophecy in the person of Akbar. ${ }^{223} \mathrm{He}$ thus managed to position Akbar above even Timur, as the eighth star and "possessor of world wide sovereignty." In his listing of Mughal ancestry from Timur onwards, Abu'l Fazl reversed his previous pattern by "counting backwards," describing each new generation as ancestors of Akbar rather than descendants of great predecessors, such as Adam, Timur or Chingiz Khan. With the political legitimacy of the dynasty firmly established in its descent from the greatest kings of the Islamic and Turco-Mongol worlds, the most critical aspect of Abu'l Fazl's imperial genealogy had become the placement of Akbar at the pinnacle of a long line of conquerors and kings.

Jahangir, on the other hand, followed in his great- grandfather's footsteps in composing his own memoir, the Jahangirnama, which he began distributing in 1618 , the thirteenth year of his reign, "to bestow on individual servants and sent to other countries to be used by rulers as guides for ruling (dastur al- 'amal ruzgar khud sazand)." ${ }^{224}$ The first copy was given to his eldest son, Shah Jahan, with Jahangir's inscription expressing hope that "an examination of the contents would be acceptable to God and bring praise from the people." 225 Within the text, Jahangir interposes regular affirmations of his right to rule as "a just and equitable monarch",226 "upon whose capable shoulders He (the AllGiving Creator) draped this robe of office.... Imperial rule has been given to this

has been ubiquitous in Central Asia and Mongolia, in some regions to the present day. Babur mentions the use of rain stones among the Timurids in the Baburnama.

${ }^{223}$ Sharifuddin Ali Yazdi wrote this in the Zafarnama and it was repeated in the Habib al-Siyar by Khwandamir. Abu'l Fazl's censure is described in AN, p. 205.

${ }^{224}$ Jahangirnama, p. 270.

${ }^{225}$ Ibid. Also see p. 276: the second and third copies were made shortly after the first and distributed at the king's request to his father-in-law and close advisor, Itimad al-Dawla, and to his brother-in- law, Asaf Khan. 
petitioner at the divine court. ${ }^{, 227}$ The memoirs do not end with the distribution of the first copies but continue through the nineteenth year of Jahangir's reign, when illness prevented him from continuing. The final few years of Jahangir's life were chronicled as an appendix to his personal memoirs and with the emperor's express approval by his courtier Muhammad Hadi. Another courtier close to the king, Mu'tamid Khan, at Jahangir's request, wrote the Iqbalnama in three volumes as a history of the Mughal dynasty in India: volume one contains the history of Babur's and Humayun's reigns, the second is devoted entirely to Akbar and the third volume covers Jahangir's reign. As court historian and panegyrist, $\mathrm{Mu}$ 'tamid Khan based the final volume on Jahangir's memoir and the official interpretation of events, rendering a somewhat repetitive but appropriately laudatory account.

Shah Jahan's court produced yet another history of the reign of Jahangir, Ma asiri Jahangiri by Khwaja Kamgar Ghayrat Khan, in which Jahangir's reign is defended and Shah Jahan's behavior as the rebellious Prince Khurram is presented in a cleansed and revised version. For his own reign, Shah Jahan's courtiers produced the Amal-i Salih, by Muhammad Salih Kambu, the Padshahnama by Abd al-Hamid Lahauri (who refers to Shah Jahan as "that pride of the Guregen dynasty"), ${ }^{228}$ and the two Shahjahannama's, by Inayat Khan and Sadiq Khan.

Shah Jahan's first historian, Qazvini, who remained at the imperial court for the first ten years of the emperor's reign, describes him as being deeply involved in the process of creating an official court history, in a manner highly reminiscent of his

\footnotetext{
${ }^{226}$ Ibid., pp. 285-6.

${ }^{227}$ Ibid., p. 31. Thackston, tr., p.48.
} 
ancestor Timur. "Sometimes, the writer of these pages [Qazvini] enters the assembly"229 by imperial command and reports on the content of each and every narrative that has been written. If a slip in the contents or an error in the expression has occurred, His Majesty corrects it and guides this worthless speck of dust to the exalted words and pleasing turns of phrase that occur to the royal mind and the inclusion of which in this history would occasion felicity of expression, indeed which are necessary concomitants to this art. This honor lasts two or three gharis [about 24 minutes] or longer when there is more work." 230

The official court chronicle of the first ten years of rule by Aurangzeb, the last of "the Great Mughals," was the Alamgirnama, by Mirza Muhammad Kazim, son of Muhammad Amin Qaswini Munshi, who had composed a history of the reign of Shah Jahan. $^{231}$ The work was originally encouraged by the emperor who, like his father Shah Jahan, demanded that the author "submit his pages to the interested scrutiny of the emperor himself, and be guided in doubtful questions by information graciously given by the monarch respecting what account was to be rejected or admitted." ${ }^{, 232}$ In the thirtysecond year of his reign, however, after hearing the author's summation of his first ten

\footnotetext{
${ }^{228}$ Inayat Khan, Shah Jahan Nama, W.E. Begley and Z.A. Desai, eds., Delhi: Oxford University Press, 1990 , p. 2.

${ }^{229}$ As described in an essay by Ebba Koch, this refers to the Shah Burj pavilion, Shah Jahan's most private gathering place, reserved for meetings with the highest dignitaries and princes of the royal blood. See Ebba Koch, "Shah Jahani Painting," Mughal Art and Imperial Ideology, New Delhi: Oxford University Press, 2001, p. 132.

${ }^{230}$ Ibid., p. 132. [quoting from Kaswini, Padshahnama]. Given the intensity of the emperor's involvement in the writing process, it is easy to see why the official histories of the reign of Shah Jahan consistently lack the charm and spontaneity of most of the histories of his predecessors.

${ }^{231}$ Muhammad Amin Kaswini, Padshahnama, E\&D, VII, p. 1. "Alamgir," Seizer of the Universe, was the regnal name chosen by Aurangzeb (perhaps in direct response to the choices of his grandfather, Jahangir, Seizer of the World, and his father Shah Jahan, King of the World).

${ }^{232}$ Muhammad Kazim, Alamgirnama, E\&D, VII, p. 175. In one of the more delightful condemnations of Mughal court prose, the editor of the Alamgirnama describes the style as "strained, verbose and tedious;
} 
years, the emperor broke with dynastic tradition and demanded that all court historywriting cease, because "the cultivation of his inward piety was preferable to the ostentatious display of his achievements." ${ }^{233}$ Not only did Aurangzeb ban court histories, he stopped the recording of any and all imperial transactions. It is hard to understand the emperor's sudden reversal of support for court history, but Aurangzeb's extant personal letters, composed in the last years of his reign, express deep dissatisfaction and regret for his own rulership. He wrote to his son, "I have not been the guardian and protector of the empire. My valuable time has been passed vainly."234 Perhaps Aurangzeb hoped that in the absence of a historical record his failings as emperor would go unrecognized by future generations. Yet five collections of Aurangzeb's letters, including lengthy commentary on the responsibilities of the Mughal kings, were gathered and saved by members of the imperial court and the only complete chronicle of the period, the Ma 'asir-i Alamgiri of Muhammad Saqi Musta'id Khan, written secretly throughout the author's forty years at Aurangzeb's court, was rescued from oblivion and finished under the patronage of Inayatullah Khan, wazir of Aurangzeb's son and successor, Bahadur Shah (r. 1707- 12).

In the eighteenth century the declining Mughal court produced a surge of Timurid dynastic histories which, in an interesting twist on the late Mughal search for sources of legitimacy, emphasized the Chingizid lineage of the dynasty, including the Tazkira-i Chaghatay of Muhammad Hadi Kamwar Khan, recounting the history of the Mongols and developing a direct lineage from Chingiz Khan to the Mughal kings, ending with the

fulsome in its flattery, abusive in its censure." See Ibid., p. 177. Perhaps this influenced Aurangzeb's disinclination to allow further court histories?!

${ }^{233}$ Ibid., p. 174. 
seventh year of the reign of Muhammad Shah (1724). The Tarikh-i Chaghatay of Muhammad Shafi Tehrani begins with the history of Babur and includes part of the reign of Muhammad Shah and the withdrawal of the post-Safavid Persian expansionist Nadir Shah in 1739. In a ravaged and desolate Delhi, the power of the Mughal kings deeply diminished by war and invasion, Muhammad Shafi described yet another dramatic reversal of Mughal imperial history writing, a reversal which not incidentally confirms the importance to the Mughals of state-sponsored history. He writes of an imperial order issued immediately after the departure of Nadir Shah, demanding that "“All public officers should occupy themselves in the discharge of their ordinary duties, except the historians. These should refrain from recording the events of my reign, for at present the record cannot be a pleasant one.' ... Consequently, being helpless, all the historians obeyed the royal mandate and laid down their pens."235

As intended, these carefully controlled and manipulated dynastic regnal histories had a strong influence not only on the members of the court and foreign kings and courtiers, but on succeeding generations of the dynasty. Babur carried with him everywhere a copy of Timur's Zafarnama, which he seems to have seen as a guide not only to kingship, but to geography as well. ${ }^{236}$ Humayun also carried a copy of the Zafarnama, although his edition was a particularly important manuscript which had been copied at Sultan Husayn Bayqara's court in Harat by Ali Shir Nava'i and illustrated by the famed miniaturist Bihzad. ${ }^{237}$ The Baburnama was translated into Persian by one of

\footnotetext{
${ }^{234}$ Letter by Aurangzeb to his son, Shah Azam Shah, in Tarikh-i Iradat Khan, E\&D, VII, p. 562.

${ }^{235}$ Muhammad Shafi Tehrani, Tarikh-i Chaghatai, E\&D, VIII, p. 21-22. Italics mine.

${ }^{236}$ For example, see Baburnama, p. 473, when Babur uses the Zafarnama to identify geographic landmarks in former Timurid conquest territories.

${ }^{237}$ J.M. Rogers, Mughal Painting, London: British Museum Press, 1993, p. 32.
} 
Babur's own courtiers, Shaykh Zayn, perhaps during Babur's own lifetime, although more likely at the court of his son, Humayun. The Zayn translation was composed in "an ornate and rhetorical style," not at all on the model of the original, which may explain its subsequent lack of popularity. ${ }^{238}$ It is rarely mentioned in contemporary manuscripts and only fragments of the manuscript remain. A much more successful translation of the Baburnama, by Akbar's Khan-i Khanan, Abd al- Rahim, was fantastically illustrated on four separate occasions in the court ateliers of Akbar, ${ }^{239}$ where the Zafarnama and the Chingiznama, the Ain-i Akbar, and Persian literary classics were also illustrated. ${ }^{240}$

Gulbadan Begim's memoirs, the Humayunnama, were illustrated under the direction of Shah Jahan, who paid 8,000 rupees for the work and left an autograph note in the frontispiece, claiming it as a history "which contains an abridgement of the affairs of his majesty Sahib Qiran and of his glorious descendants.” Although he was familiar with them in the Persian translation, the fourth Mughal emperor, Jahangir, wrote touchingly of reading an original Turki copy of Babur's memoirs in "entirely his own blessed handwriting (khat-i mubarak) ...for although I grew up in Hindustan, I am not ignorant of how to read and write Turkish (dar guftan u nivishtan Turki 'ari nistam)." ${ }^{241}$ Jahangir's defensive assertion is probably accurate, for although the court language of the Mughals was Persian, at least as late as the reign of Aurangzeb (1618-1707), at whose court the title Chaghatay was bestowed as a mark of imperial favor, ${ }^{242}$ royal children

\footnotetext{
${ }^{238}$ The fragments are in the British Library, MS Add. No. 26, p. 202; MS OR 1 p. 999. See in AN, I, pp. $248-9$, note 5 .

${ }^{239}$ Ca. 1590 edition, British Library, MS OR 3714.

${ }^{240}$ Abu'l Fazl, Ain-i Akbari (Cited henceforth as AA), in 3 vols., H. Blochmann, tr., Delhi: Low Price Publications, I, p. 115. More on Mughal book production and illustration in ethics chapter, this dissertation.

${ }^{241}$ Jahangirnama, p. 64. Thackston, tr., p. 77.

${ }^{242}$ Richard C. Foltz, Mughal India and Central Asia, p. 37.
} 
were schooled in the Turkish language of their Central Asian ancestors. ${ }^{243}$ Fulfilling Jahangir's desire that his own memoir "be sent to other countries to be used by the rulers as guides,"244 the Jahangirnama was translated into Ottoman Turkish in the eighteenth century at the imperial Ottoman court in Istanbul by order of Sultan Mustafa III. ${ }^{245}$ In an illustration of the continued power of Mughal history writing, and the revanchist nostalgia which continued to cling to the Mughal kings, a new series of illustrations was commissioned at the Mughal court for the Iqbalnama-i Jahangiri as late as the nineteenth century, with the last shreds of Mughal power in imminent collapse. ${ }^{246}$

Just as Timur had shown great care and personal attention in the development of a legitimizing history, his descendants in Timurid Central Asia and in India were deeply involved in producing memoirs and chronicles as an expression of dynastic identity. Mughal patronage of writers and historians, the establishment of sophisticated and wellpopulated imperial workshops and personal involvement by Mughal royals in the process illustrate imperial awareness that these writings would significantly impact perceptions of Mughal legitimacy, on an individual level as well as dynastic, among members of the family, the nobility, and internationally. Every generation of Timurid-Mughal nobility produced a body of carefully crafted legitimizing texts, defending the right of individual and dynastic rule. Of equal import to successive generations of Mughals, these texts were imbedded with explanations and descriptions of Timurid-Mughal cultural attributes,

\footnotetext{
${ }^{243}$ Bakhtawar Khan, Mirat- $i$ Alam, E\&D, VII, p. 162. See also Saqi Musta'id Khan, Ma 'asir-i Alamgiri, E\&D, VII, pp. 195-6, who describes Aurangzeb’s sons Muhammad Kam Baksh and Muhammad Sultan as proficient in Turkish.

244 Jahangirnama, p. 270.

${ }^{245}$ British Library, MS OR 6441.

${ }^{246}$ British Library, MS OR 14342. The decline of the imperial workshops is evident. Illustrations for the nineteenth-century version are neither Timurid nor Mughal in style. The figures are posed in the Timurid
} 
court traditions, understandings of law, religion and family. As the Mughal royals pored over, translated, discussed, scrawled on and cross- referenced these works, they assimilated and absorbed the sum of the dynasty's constructed imperial identity to date-a cultural personality that marked them and defined them-- resulting in a remarkably high degree of cultural and imperial continuity for over two hundred years in Mughal India.

Illustration as a Tool in the Imperial Identity Project

The audience for written texts is limited by levels of literacy and shared language. In the multi- lingual, semi- literate milieu of Timur's court ${ }^{247}$ pictures became a useful tool in the establishment of public identity. A master manipulator of arts and architecture in the interests of his imperial image, employing his preferred monumental presentation, Timur had his palace walls decorated with murals illustrating imperial power and grandeur. A contemporary observer described an extensive display:

He had depicted his assemblies and his own likeness, now smiling, now austere, and representations of his battles and sieges and his conversation with kings, amirs, lords, wise men, and magnates, and Sultans offering homage to him and bringing gifts to him from every side and his hunting nets and ambushes and battles in India, Dasht and Persia, and how he gained victory and how his enemy was scattered and driven to flight; and the likeness of his sons and grandsons, amirs and soldiers and his public feasts and the goblets of wine and cup bearers and zither-players of his mirth and his love meetings and the concubines of his majesty and the royal wives and many other things which happened in his realms... and therein he intended that those who knew not his affairs should see them as though present. ${ }^{248}$

tradition, but all of the faces have Indian features rather than Turkish or Mongol, and Mughal use of perspective and shading are entirely lacking.

${ }^{247}$ Timur himself was said to be illiterate, as was his distant descendant, the Mughal emperor, Akbar.

${ }^{248}$ Ibn Arabshah, Tamerlane, p. 310. 
Evidence exists of similar paintings hung in Timur's Bagh-i Shamal and Dilkushay gardens, perhaps resting near the fabulous tapestry of Sultan Bayezid, taken as plunder from the Ottoman treasury. ${ }^{249}$

Timur's successors continued the use of wall painting as a device of imperial image making and confirmation of cultural prowess. Paintings are mentioned in the tarabkhana (joyhouse) of Abu Sa id in Harat. ${ }^{250}$ A document from the royal workshop of Baysunghur ibn Shahrukh, dating ca. 1427-28, refers to a structure called the surat khana, or "picture gallery," being built on the grounds of the palace, perhaps including portrait murals. ${ }^{251}$ No known murals matching those described in the sources now remain but related Timurid illustrations, containing similar cartouches, medallion forms, chinoiserie, and landscape elements, reinforce the probability of their existence at the Timurid courts of Mawarannahr and Khurasan. ${ }^{252}$ Paintings and drawings exist whose large size, bold presentation and subject matter, suggest that their original purpose was to serve as studies for wall paintings, and a fifteenth-century illustration in Nizami's Haft Paykar (Seven Portraits) shows a palace room decorated with large wall paintings of seven princesses. ${ }^{253}$

Babur would have seen these vast Timurid palace wall paintings when he briefly ruled Samarqand and visited Harat. Perhaps he imitated them at his own courts in Kabul and in Agra; certainly his successors employed very similar wall painting in their palaces in India. While the aniconic Ottomans shied away from large- scale portraiture, Mughals

\footnotetext{
${ }^{249}$ Thomas W. Lentz, "Dynastic Imagery in Early Timurid Wall Painting," Muqarnas, Vol. 10 (1993), p. 253.

${ }^{250}$ Lentz, "Dynastic Imagery," p. 253.

${ }^{251}$ Jafar Tabrizi, “Arzadasht," Topkapi Sarayi Muzesi (H. 2153, folio 98a), in Thackston, CP, p. 326. See also Lentz, "Dynastic Imagery," p. 254.
} 
(and to some extent Safavids ${ }^{254}$ ) covered their palace walls with frescoes of family gatherings, most particularly, in the Mughal case, highlighting their genealogical descent and confirming dynastic legitimacy. Many are reputed to have included family groupings, while some portrayed idealized allegorical scenes of the ruling emperor and his sons seated with their deceased royal ancestors, particularly Timur. ${ }^{255}$ Genealogical portraits did not remain static in the Mughal palace but could be retouched to include successors and their sons. For example the painting known as "Princes of the House of Timur," representing an imaginary garden party including Timur, Babur and Humayun, was originally painted during Humayun's interregnum in Kabul (ca. 1550- 55?) but was later reworked to include Akbar, Jahangir and a young prince Shah Jahan in what had become a vast panoramic celebration of the Timurid royal lineage. ${ }^{256}$ There is some disagreement among modern scholars as to the true identity of the painting's subjects, but what is important is that the Mughal dynasts believed it to be a genealogical study and amended it regularly to retain that quality.

On a more intimate level, literary illustration had emerged in the Islamic world among the Turco- Mongol dynasties of the fourteenth century, particularly the western

\footnotetext{
${ }^{252}$ Lentz, "Dynastic Imagery," pp. 254-5.

${ }^{253}$ Ibid.

${ }^{254}$ Shah Tahmasp is reputed to have decorated the Chihil Palace at Qazvin with, among other scenes, portrayals of Joseph appearing before Zulaykha. Traces of these small- scale paintings could be detected in the 1960's. See Rogers, Mughal Miniatures, p. 34.

${ }^{255}$ Gülru Necipoğlu, "Word and Image: The Serial Portraits of Ottoman Sultans in Comparative Perspective," The Sultan's Portrait, Selim Kangal, ed., Istanbul: Is Bankasi, 2000, pp. 54- 5.

${ }^{256}$ Currently in the British Museum (MS OA 1913 2-8 01) the painting is considered perhaps the most significant of Timurid- Mughal paintings. The final number of figures in the painting includes four persons inside the garden pavilion, with twelve more (princes?) and a number of manservants placed around it. Ibid., p. 57. It was certainly produced for Humayun, probably by his Persian painters Abd al- Samad and Mir Sayyid Ali. See Rogers, Mughal Miniatures, p. 36.
} 
Iranian Jalayirids. ${ }^{257}$ Timurid commitment to Persian literature, and their deliberate use of dynastic historiographies as a strategy to establish political legitimacy, led to the abundant production of illustrated texts, which came to be seen as "the supreme expression of Timurid taste." 258 The Timurids developed artistic conventions and devices which had been inherited from Turco- Mongol and Persian traditions, inspired by Chinese models and Chinese obsession with dynastic history, into a distinctive style which "best conveyed the ideals of the dynasty," and came to be seen as canonical by contemporary dynasties such as the Ottomans and Safavids. ${ }^{259}$ Timurid royal portraiture balanced concern for a true likeness with idealized conventions which had become codified by the fifteenth century. ${ }^{260}$ Much of the iconography that informs Ottoman, Safavid and early Mughal works can be identified in Timurid royal portraits. For example, in recognition of his lack of royal descent, portraits of Timur position the conqueror in a kneeling pose, whereas portraits of his sons, progeny of Chingizid princesses, were posed in the cross- legged position that indicated royal status. An early Timurid genealogical portrait series (ca. 1405) is illustrated with three-quarter-view portraits of princes and princesses, the subject kneeling, sitting cross- legged, or sitting with one leg underneath the body, and bearing the "insignia of royalty:" handkerchief, flower, bow, thumb ring, mace, or distinctive headgear. ${ }^{261}$ Timurid imperial portraits were not intended solely to provide a record of distinct individuals; in addition, they stressed a common dynastic bond, while shared imperial attributes affirmed the power

\footnotetext{
${ }^{257}$ Lentz and Lowry, p. 115.

${ }^{258}$ Ibid., p. 114.

${ }^{259}$ Ibid., p. 171.

${ }^{260}$ Necipoğlu, "Word and Image," p. 24.

${ }^{261}$ Ibid., p. 25.
} 
and legitimacy of the imperial succession. ${ }^{262}$ Although seemingly intimate and deeply

personal, the portraits can be seen as "an official imagery of the ruling house."263

There is no evidence that Babur set up imperial painting workshops in Kabul, although not to have done so would seem to be completely out of character for this ardent collector and connoisseur of literary arts. He was a covetous bibliophile-- regularly quoting from the Persian literary classics, voracious in his manuscript acquisitions, despairing at their loss. Among many other manuscripts, such as the Zafarnama of Timur, which he habitually kept close at hand, he is known to have owned an illustrated copy of the Shahnama, or Book of Kings, originally produced for Timur's grandson Muhammad Juki in 1440, marked with Babur's seal and the date 906 AH (1501), the year he first gained the throne of Samarqand. ${ }^{264}$

Humayun was a highly literate bibliophile like his father. ${ }^{265}$ While in exile at the Safavid royal court of Shah Tahmasp in 1544, he invited two of the most famous painters of Safavid Iran to join him when he regained the throne in India. ${ }^{266}$ The painters, Mir Sayyid Ali and Abd al-Samad, accompanied Humayun on his reconquest of India, arriving in Kabul in 1549- 50. They were joined soon after by two more Persian painters, Mir Musavvar and Dost Muhammad. ${ }^{267}$ These artists are generally considered to have

\footnotetext{
${ }^{262}$ Ibid., p. 25. Necipoğlu's interest is in the degree to which this was true of Ottoman portraiture, but I have applied her points to the production of canonical Timurid royal portraits.

${ }^{263}$ Lentz, "Dynastic Imagery," p. 263.

${ }^{264}$ Rogers, Mughal Miniatures, p. 28.

${ }^{265}$ Ironically, he died in a fall from the steps of his library in Delhi. As for his love of books, according to his biographer, Jauhar Aftabchi, even while in desperate flight from his disloyal brother Kamran, Humayun thought to ask after the safety of his library. Jauhar Aftabchi, Tazkirat-i Waqi 'at, British Library MS Add. 16711, fol. 99b. See also Jouher, Tezkereh al-Vakiat, Major Charles Stewart, tr., New Delhi: Kumar Brothers, 1970.

${ }^{266}$ Shah Tahmasp seems to have had a crisis of conscience regarding the production of portraiture at his highly religious conservative court and was clearly willing to let his court painters depart for India. ${ }^{267}$ Joseph M. Dye III, "Imperial Mughal Painting," in The Magnificent Mughals, Ziad, ed., Oxford University Press, 2002, p. 147.
} 
had a powerful formative influence on Mughal painting, although the canonical forms and images of Timurid painting had already had enormous influence on Persian production, making identification of a single original source for Mughal painting extremely difficult.

Within Humayun's imperial ateliers no homogeneous style emerged in the production of what were highly standardized representations of imperial themes; certainly the Timurid- Persianate tradition of imperial painting continued to dominate. Imperial portraiture was a priority: Abd al-Samad was reportedly commissioned in 1551 to paint a portrait of Akbar painting (he was trained to paint in his youth), and portraits of Humayun, some with his sons, may have been executed during his own reign. A portrait of Humayun with his son Kamran Mirza may have been produced at Kamran's court at Kabul, indicating that Mughal princes were continuing the tradition of separate workshops at rival princely courts. ${ }^{268}$ On his own accession to the Mughal throne, Akbar supported the continued imperial patronage of painters, and is quoted as saying, "There are many who hate painting; but such men I dislike. It appears to me as if a painter had a quite peculiar means of recognizing God." ${ }^{269}$ He ordered Humayun's Persian painters to expand the imperial ateliers, hiring local artists using indigenous forms as well as those trained in the Timurid tradition.

The production of the royal workshops in India asserted Mughal dynastic genealogy, imperial grandeur, and religious loyalties and explored and expanded on the images of individual kings. Although his original commissions from the painters of the imperial ateliers were illustrations of Persian language classics of adventure and fantasy,

\footnotetext{
${ }^{268}$ Ibid, 39.
} 
including the Tutinama, Tales of a Parrot, which may originally have been commissioned by Humayun, and a voluminous fourteen-volume Hamzanama, Tales of Amir Hamza, which took over fifteen years to complete and contained over 1,400 illustrations. ${ }^{270}$ By the 1580 's, however, Akbar had steered his workshop toward the production of illustrated dynastic histories and royal portraiture. As previously mentioned, his workshops illustrated the Timurnama (ca. 1584), a history of Timur and his descendants including Akbar; the Baburnama (1589), Babur's autobiographical memoir (newly translated into Timurid- Mughal court Persian from its original Turki); the Akbarnama (ca. 1590), the history of Akbar's own reign, which carefully traced his lineage through the Timurid line to the great Mongol ancestress, Alanqua; and the Chingiznama (1596), a history of Chingiz Khan and the Mongols, based on that of Rashid al-Din. Each of these histories was given roughly 150 lavish color illustrations (manuscripts at the Safavid court prior to the reign of Shah Tahmasp averaged only 40 illustrations) $^{271}$ and some saw several editions, with entirely new sets of illustrations. In 1581-2 Akbar commissioned an illustrated history of Islam's first one thousand years, the Tarikh-i Alfi, which presents this history as culminating in the reign of Akbar, ruler of the new millennium. ${ }^{272}$ Apart from the numbers of literary works and histories illustrated in the workshops of Akbar's court, the emperor commissioned "an immense album," in which were collected painted portraits of the emperor, for which he posed, and of all the

\footnotetext{
${ }^{269}$ Abu'l Fazl, AA, I, p. 115.

${ }^{270}$ Rogers, Mughal Miniatures, p. 77. The Tutinama is a colection of Hindu morality tales, written in Persian in the period of the early Delhi Sultanate. The Hamzanama is an adventure story extolling the highly idealized exploits of the Prophet's uncle.

${ }^{271}$ Dye, "Imperial Mughal Painting," p. 152.

${ }^{272}$ Abd al-Qadir ibn Muluk Shah Badauni, Muntakhabu al-Tawarikh, Sir Wolseley Haig, tr., Brahmadeva Prasad Ambashthya, ed., Patna, India: Academica Asiatica, 1973, II, p. 329. (See below, chapter six, for more details on the Mughal translation movement.)
} 
nobles of the empire, so that "those who have passed away receive new life and those who are still alive have immortality promised them," a description which may indicate the inclusion of genealogical studies within the portfolio. ${ }^{273}$

Whereas the few extant portraits of Humayun reflected an artistic, literary soul ${ }^{274}$ the royal portraiture of his successor, Akbar, are imbued with the emperor's dynamic personality and imperial image, emphasizing either his Timurid lineage or events of political and military importance: battle scenes, hunting scenes, imperial punishments, ceremonial receptions and royal births. ${ }^{275}$ "The presentation of Akbar, like that of Timur earlier, stressed his role as conqueror, as well as his dynamism and omnipotence." ${ }^{276}$ As the true empire-builder of the Mughal lineage, Akbar is portrayed as an intensely physical presence, bent on the subjugation of both elephant and empire.

In contrast, the Jahangirnama, for which the emperor Jahangir himself commissioned specific paintings to fit the text, contains not a single battle scene, but focuses instead on showing sumptuous imperial audiences and allegorical scenes emphasizing his imperial hegemony and his religious legitimacy. The single painting of an active Jahangir shows him at the conclusion of a lion hunt, "an ancient and symbolic image of royal power, ${ }^{277}$ which for Jahangir was far more than a pose, as he passionately loved the hunt and indulged frequently. Unlike his ambitious father, who in his youth had been required to re-conquer much of his patrimony, Jahangir, heir to a stable empire

\footnotetext{
${ }^{273}$ Abu'l Fazl, AN, I, p. 115.

${ }^{274}$ Produced in the imperial ateliers of Jahangir, a particular portrait of Humayun shows the emperor reclining high up in a treehouse reading a book, as musicians perform at the base of the tree. See Annemarie Schimmel, The Empire of the Great Mughals, London: Reaktion Books, 2004, p. 27.

${ }^{275}$ Milo C. Beach, “Jahangir's Jahangir- Nama," Powers of Art, Barbara Stoler Miller, ed., Delhi: Oxford University Press, 1992, p. 228.

${ }^{276}$ Ibid.

${ }^{277}$ Ibid.
} 
with a full treasury, commissioned an imperial image of serenity and security. Yet this relative passivity was no less a traditional Timurid imperial image than that of the conquering Akbar. Timurid royal portraits too had emphasized the princely pleasures of hunting, reclining in beautifully landscaped gardens, reading, writing, gazing at the beloved - all expressed with an enviable delicacy of temperament and artistic sensitivity — in stark contrast to contemporary European kings whose imperial imagemakers most often posed them on charging steeds and in military postures.

After 1615, imperial portraiture came increasingly to be dominated by overt, often allegorical, political messages rather than following the traditional Timurid narrative format. An example is Abu al-Hasan's painting Jahangir Embracing Shah Abbas, in which the two kings, standing on a globe of the earth and framed by celebrating cherubim and luminous halos of sun and moon, meet in a warm fraternal embrace. Painted in 1618 , the portrait was not only a grandiose commentary on the haloed Mughal emperor's inviolability, but an imperial response to the nagging question of the status of Qandahar, at the time a Mughal territory, although it would be agin seized by the Safavids in 1622 . The powerful figure of Jahangir, firmly planted on the back of a lion, looms over the shrunken frame of Abbas, who cowers on an equally meek-seeming lamb. A remarkably similar portrait of Shah Jahan, though far more rigidly formal and iconic in tone, positions the haloed emperor on a globe, the very same lamb and lion at his feet and similar cherubim celebrating his imperial grandeur, in a bald statement of imperial power. $^{278}$

${ }^{278}$ Dye, “Imperial Mughal Painting," p. 175. 
Over time, imperial portraiture came to rely heavily on the motif of the jharoka-i khass $u$ 'amm, the hall of public audience, "the administrative center of the Mughal Empire and the focal point of court events." In Jahangir's time these highly detailed scenes depicted historical events: court festivals, weighing ceremonies, elephant fights, the punishment of the guilty, the exchange of gifts and distribution of honors, the emperor regally overseeing carefully positioned crowds of specific and identifiable nobles and their elaborate retinues. Under Shah Jahan these paintings developed into fabulous yet increasingly stiff, abstract and iconic images of the imperial power structure. ${ }^{279}$ Portraits produced during the reigns of Jahangir and Shah Jahan began to frame the emperors with golden halos, emphasizing their increasingly sacral presentation. Even the aniconic Aurangzeb, during whose more conservative orthodox reign patronage of the Mughal imperial atelier diminished, was portrayed by the court painters in the idealized regnal pose, halo firmly in place.

Genealogical portraits remained a constant theme in Mughal miniature painting, particularly studies of impossibly disparate generations united in sympathetic communion, as when Shah Jahan's imperial atelier produced allegorical scenes of Timur passing an imperial crown to Babur in the presence of Humayun. ${ }^{280}$ Popular religious figures were similarly treated. Jahangir had himself painted with a variety of holy men, including not only Sufis but Hindu ascetics, with whom he described himself as being in regular contact and conversation. In particular, Akbar and Jahangir were pictured in close and affectionate communion with the Chishti Shaykh Salim, a holy man equally

\footnotetext{
${ }^{279}$ Ebba Koch, "The Hierarchical Principles of Shah Jahani Painting," Mughal Art and Imperial Ideology, New Delhi: Oxford University Press, 2002, pp.132-3.
} 
influential within Hindu and Muslim communities, who had prophesied the birth of Akbar's sons and next to whose dargah (tomb/shrine) Akbar constructed his imperial capital, Fatehpur Sikri. Years later, Shah Jahan had his own portrait juxtaposed on a single page with a portrait of the (deceased) Shaykh Salim. ${ }^{281}$ Mughal interest in the sustained ability of the Chishti order to confer legitimacy is illustrated by an allegorical portrait from the eighteenth century displaying two unidentified Mughal princes seated comfortably beside the same (by now long deceased) Shaykh Salim Chishti, affirming continued imperial loyalty to the Chishtiyyah Sufi order even in the years of Mughal collapse. $^{282}$

Contemporary sources confirm that the Mughal kings were deeply involved in the establishment and production of an illustrated imperial image. At Akbar's court, "the art flourishes, and many painters have obtained great reputation. The works of all painters are weekly laid before His Majesty by the Daroghas and the clerks; then he confers rewards according to the excellence of workmanship, or increases the monthly salaries." ${ }^{283}$ Considered the most deeply involved patron of all the Mughal kings, Jahangir claimed, "I derive such enjoyment from painting and have such expertise in judging it that, even without the artist's name being mentioned, no work of past or present masters can be shown to me that I do not instantly recognize who did it." ${ }^{284}$

\footnotetext{
${ }^{280}$ Victoria and Albert Museum, London. Painting by Govardan, reproduced by Schimmel, The Empire of the Great Mughals, p. 16.

${ }^{281}$ On display at theArcheological Museum, The Red Fort (Shahjahanabad), Delhi, as of January 2006.

${ }^{282}$ On display at the Archeological Museum, The Red Fort (Shahjahanabad), Delhi, as of January 2006.

${ }^{283}$ Abu'l Fazl, AN, I, p. 113.

${ }^{284}$ Jahangirnama, pp. 266-7. Thackston, p. 268.
} 
Yet none retained tighter control over the production of imperial imagery than Shah Jahan, who visited his imperial artisans daily, offering criticism and advice. ${ }^{285}$ The emperor's rigid court ceremonial was matched by "his increasing formalization of the court arts, which were represented as a necessary instrument to rule. ${ }^{286}$ His portraits, far less evocative of the physical man than those of his predecessors, show him always in profile, ageless and unlined, pious and haloed, truly deserving of his regnal name, Shah Jahan, King of the World. That a critical political role had been given to the arts by the Mughal kings was clearly understood by Shah Jahan's courtiers and artisans, whose responsibility it was to articulate and promulgate the imperial image. " [Such matters] may belong [to the category] of beautiful and external things the existence of which is not so necessary [in the context] of overall rule, but they must be [present] to give full distinction and spectacular display-the more so since it becomes a matter of increase of pomp and power, magnificence and elegance.... It is evident that the increase of such things creates esteem for the ruler in the eyes [of the people] and augments their respect [for the ruler] and [their own] dignity in [their] hearts. In this form the execution of divine injunctions and prohibitions and the enforcement of divine decrees and laws, which is the ultimate aim of rulership and kingship, are carried out in a better way., 287

\section{The Imperialism of Architecture and Landscape}

In the spirit of Timur, and reflecting the near-universal compulsion of early modern rulers, the Mughal conquerors of India constructed vast imperial buildings,

\footnotetext{
${ }^{285}$ Kazwini, Padshahnama, fol. 139a., cited in Ebba Koch, "Shah Jahani Painting,” p. 131.

${ }^{286}$ Ebba Koch, "Shah Jahani Painting," p. 130.

${ }^{287}$ Kanbu, Amal- $i$ Salih, III, 1960, pp.24-5. Cited in Koch, "Shah Jahani Painting,” p. 131. Italics mine.
} 
mosques, marketplaces, caravanserais and entire cities as evidence and affirmation of imperial might and right to rule. The impulse was expressed early, with Humayun's construction of Din Panah, an imperial capital on the banks of the Jamuna River, later destroyed by the victorious Afghan king Shir (Khan) Shah Sur, who built in its place the citadel known as Purana Qila, the vast ruins of which still cover a large territory in old Delhi. $^{288}$

Akbar built a series of fortresses across his domain, including a fort at Agra that was said to comprise over five hundred buildings, which Abu'l Fazl referred to as "the center of Hindustan.,289 More significantly, Akbar constructed an entire imperial capital city thirty- five kilometers from Agra at Sikri, the home of the renowned mystic Shaykh Salim, whom Akbar publicly venerated. ${ }^{290}$ Positioning his new imperial center in close proximity to the shrine of the exceptionally popular shaykh, whose following was as much Hindu as Muslim, Akbar very openly co- opted an acclaimed public source of religious charisma and legitimacy. The very architecture of Akbar's city, a wildly original amalgam of Perso- Timurid and indigenous Indian design features, demonstrated a deliberate convergence of Mughal political authority by affirming both the historical

\footnotetext{
${ }^{288}$ Purana Qila covers acres of territory, with monumental stone ruins of imperial buildings in the squat and heavy Afghan style. Its vast parkland is immediately adjacent to the city zoo and so serves Delhi as a popular picnic site. Incidentally, it has been suggested that the three magnificent mausolea subsequently built by Shir Shah for his deceased father and grandfather and for himself, through which genealogical aggrandizement he perhaps hoped to establish a fictitious noble lineage, was later to inspire and encourage the Mughals to construct their own monumental imperial mausolea, so as not to be outdone by their rival. See Catherine B. Asher, "Architecture," The Magnificent Mughals, Zeenut Ziad, ed., Oxford University Press, 2002, 183- 228, 188.

${ }^{289}$ Abu'l Fazl, AA, II, p. 191.

${ }^{290}$ Akbar also constructed a large mosque at the Chishti shrine complex in Ajmer in Rajasthan, to which the emperor regularly made pilgrimages, at times barefoot. A full discussion of the Mughal relationship with the Chishtiyya order of Sufis will be included in chapter six.
} 
legacy of the dynasty and imperial loyalty to the disparate social and political realities of rule on the subcontinent.

Shah Jahan, whose impulse to articulate an imperial image took its highest form architecturally, returned the imperial capital to Delhi, where he constructed an entirely new imperial palace complex, which he named Shahjahanabad, now known as the Red Fort. Here the Divan-i Amm, or Hall of Public Audience, center of imperial political and religious ritual, was adorned with mosaic inlays elaborataly depicting Orpheus taming wild animals, evoking "an Islamic understanding of Solomon's throne - the seat of the ideal just ruler. ${ }^{291}$ The private rooms of the palace were decorated in gilded carvings in high relief of paradisiacal panoramas and a scale of justice, next to which inscriptions praised Shah Jahan and compared the palace to "the mansions of paradise." In the private Hall of Audience were carved the verses of the fourteenth-century Indian Muslim poet, Amir Khusraw proclaiming this a paradise on earth. ${ }^{292}$

Eger firdaus bar ruy zamin ast

Hamin ast, hamin ast, hamin ast.

If there is a paradise on earth, This is it, this is it, this is it.

The audience halls of the imperial forts constructed by Shah Jahan in Lahore and Agra --for which construction existing forts built by Akbar and Jahangir were removed-were likewise intended to evoke the audience halls of Persepolis, believed to have been built by King Solomon, the Just. ${ }^{293}$ Just outside the imperial palace walls, Shah Jahan constructed what was in its day the largest mosque in the Islamic world, the Masjid-i

\footnotetext{
${ }^{291}$ Asher, "Architecture," The Magnificent Mughals, p. 211.

${ }^{292}$ Ibid., p. 212.
} 
Jahannuma. Its façade was covered with inscriptions which seemed from afar, due to their placement and ornate calligraphy, to be verses from the Quran but were instead Persian panegyrics to Shah Jahan! ${ }^{294}$

As with all other public displays of imperial legitimacy, the fifth Mughal emperor was deeply involved in the image- making process. "The superintendents of the imperial buildings (daroghaha-i 'imarat-i sarkar-i khassa-i sharifa), together with the masterful architects of excellent abilities (mi maran mahir nadira kar) bring architectural design before the exalted sight [of the emperor]. And since his most pure mind is inclined entirely towards building... he attends to it fully by creating most of the designs himself and also by carrying out appropriate changes to whatever the architects have thought out." 295 "In accordance with the saying, 'Verily our relics speak of us,' the majority of the buildings he designs himself... after long consideration he makes appropriate alterations and emendations. ${ }^{, 296}$

Yet while Mughal emperors indulged in public aggrandizement of the Mughal imperium through the erection of monumental structures, and even cities-- none of which, no matter how splendid, innovative, accessible or enlightened, remained the imperial center for long-- far more significant in context and scope was the landscaping of traditional Timurid gardens. ${ }^{297}$ Much has been written about the classical Timurid

\footnotetext{
${ }^{293}$ Ibid., p. 208.

${ }^{294}$ Ibid., p. 212.

${ }^{295}$ Kazwini, Padshahnama, in "Shah Jahani Painting," Ebba Koch, tr., Mughal Art, p. 131.

${ }^{296}$ Inayat Khan, Shah Jahan Nama, p. 570.

${ }^{297}$ This is not to say that Mughal architecture had no lasting influence. While rejecting the request by supporters of the last Mughal emperor Bahadur Shah to build for him a mausoleum in the style of the Taj Mahal, the British employed a "Mughalized style" for mosque architecture in British- controlled Malaya and built in the British resort town of Brighton the remarkable Prince of Wales Royal Pavilion, whose "rather fantastic domed and arched exterior is an amazing interpretation of Mughal architecture." Its Arabian Nights profile remains to this day iconic and unexpected. See Asher, "Architecture," p. 225.
} 
garden, described as "the pinnacle of the art of garden design in medieval Iran and Central Asia." ${ }^{298}$ While the generic garden, bagh, was admired in a variety of shapes and styles, the formal chahar-bagh was considered by many in Timurid Transoxiana to be the most estimable landscape form. The chahar-bagh was composed of a rectangular grid split by symmetrical waterways to form four garden areas of fruit trees, herbs, flowers, and even vegetables, usually centered on a pavilion or other garden structure. One of Timur's biographers describes the construction of what may have been a classic chaharbagh en route from Timur's winter quarters to the capital city: "Along the way is a mountain, approximately seven parasangs from Samarqand, and at the pass flows a river. When the mighty emperor reached that mountain, since his realm- adorning mind never missed an opportunity to build something in any place that was worthy of a structure, he ordered a garden laid out there in such a way that the sweet waters of the river would flow through the garden...."

Highland and lowland, steppe and plain, were Turned into pleasure parks like the gardens of Paradise.

Forage herbs became tulips, stones became Rubies and pearls, grass became elixir, and the Ground became gold. ${ }^{299}$

Yet while the chahar-bagh was admired in fifteenth-century Central Asia for its sophisticated geometric form and physical beauty, it is possible that the enormous prestige, even reverence, it acquired in the late Timurid period was due in some measure to the function of the garden as a popular site of artistic and social expression. It was the life within the garden, as much as the garden itself, which resonated in the Timurid

\footnotetext{
${ }^{298}$ M. E. Subtelny, "Mirak-i Sayyid Ghiyas and the Timurid Tradition of Landscape Architecture," Studia Iranica 24 (1995), p. 20.
} 
psyche. Inspired by the relative freedom of the gardens' open spaces, the beauty of their lush yet tightly controlled flora, the prestige of ownership, and not least the implications for membership in elite literary circles, leading personalities of Harat developed a taste for large and sophisticated classical gardens, which came to be recognized as important urban architectural landmarks. ${ }^{300}$ During his three brief occupations of Samarqand and during his visit to Harat in 1506, Babur had toured many of the cities' baghs and chaharbaghs, confirming his deep personal admiration for the gardens and the late Timurid social milieu the landscapes had come to symbolize. It was this romantic vision of late Timurid courtly life, exemplified by the classical garden and the life played out within it, which Babur and his descendants would attempt to reproduce in their conquered territories over two hundred and fifty years of rule in India. In contrast to their Ottoman contemporaries, the Mughals' conquest of India “came to be expressed hardly at all in religious monuments but pervasively as the imperialism of landscape architecture, the civilized ideal of the Timurid period." 301

As the ruler of Delhi, Babur expressed appreciation for India's vast wealth and uncountable numbers of skilled craftsmen, yet for the Timurid prince India's failings-- its heat and dust, its lack of melons and madrasas-- seem to have centered on and became encapsulated in the region's utter lack of a classical garden or appropriate space upon which to build one. ${ }^{302}$ "Everywhere I looked," he wrote, "was so unpleasant and desolate (karahat $u$ nakhoshluk) .... Because the place was so ugly and unpleasant I abandoned

\footnotetext{
${ }^{299}$ Sharifuddin Ali Yazdi, Zafarnama, p. 91.

${ }^{300}$ For example, see Subtelny, "Ghiyas."

${ }^{301}$ Dale, Garden, p. 186.

${ }^{302}$ Baburnama, Mano, p. 468. Thackston, tr., pp. 642-3.
} 
my dream of building a chahar-bagh. ${ }^{, 303}$ Already homesick, he directed the women and children who had remained in Kabul to travel in state to the Garden of the Audience Hall (bagh-i divanhana) and "when a pleasant meeting place was arranged," to offer prostrations and give thanks, celebrating his victories in India in the manner he himself would have preferred..$^{304}$

Yet life without gardens was unthinkable, and while Babur could not improve India's climate or native flora, with Timurid pragmatism and willingness to compromise, a proper garden could be constructed. Eventually, imposing his will on the recalcitrant Indian landscape, Babur was to order a classic Timurid garden built in every place he settled. "There was nothing to do but work with the space we had.... Thus in unpleasant and unharmonious India (bisafa u bisiyaq Hind), marvelously regular and geometric gardens were introduced." ${ }^{305}$ An Afghan historian of the Sur dynasty of Humayun's nemesis, Sher Shah, described Babur's first garden, writing, "And in the second year of his reign [in India] Hazrat Giti Sitani [i.e., Babur] laid out a garden without equal (bagh-i binazir) on the banks of the Jamuna. And it was the first example of a plan with walkways in Hindustan (Tar bandi-yi khiyaban awwal dar Hindustan namudar shud).... And on the pattern of this garden Mirza Kamran [Babur's son] made another garden at Lahore." ${ }^{306}$ As his son's example indicates, Babur was not the only immigrant from Transoxiana who admired and longed for the classic baghs of Transoxiana. "All who had acquired lands on the [Jamuna] river," Babur noted, listing his Turkish companions by

\footnotetext{
${ }^{303}$ Ibid., Mano, p. 482. Thackston, p. 642.

${ }^{304}$ Humayunnama, p. 12.

305 Baburnama, Mano, p. 482, Thackston, tr., p. 642.

${ }^{306}$ Ahmad Yadgar, Tarikh-i Shahi, pp. 120-21. Quoted in Ebba Koch, "The Mughal Waterfront garden," Gardens in the Time of the Great Muslim Empires, ed. Attilio Petruccioli, Leiden: Brill, 1997, p. 140.
} 
name, "also built geometric and beautifully planned gardens and pools." Babur confirmed the originality of the Timurid garden in India, adding, "Since the people of India had never seen such planned or regular spaces they nicknamed the side of the Jamuna on which those structures stood, Kabul.,"307

The beloved Mughal province of Kashmir is believed to have contained by the mid- seventeenth century a total of 777 Mughal gardens, including the prototype for Lahore's Shalimar. ${ }^{308}$ Lahore, considered the second city of the Empire under Akbar and a favorite location for Jahangir's peripatetic court due in large part to its mild climate and relatively close proximity to Kashmir and Kabul, came to contain fifty Mughal gardens in the classic Timurid style, one of which, the circular Gul Bagh (Rose Garden), was perhaps the largest garden in the world, completely surrounding the city with a five-mile belt of planned landscaping. So many gardeners and craftspeople were required for the development and upkeep of Lahore's gardens that entire "satellite settlements" were constructed near the gardens to house the population of laborers, such as the communities of Baghanpura, Begimpura and Shahdara. ${ }^{309}$ In recognition of the construction of the Shalimar Bagh, called by Shah Jahan Farah Baksh (Garden of Delight) and Faiz Baksh (Garden of Bounty) $^{310}$ and built by him at a cost of six lakhs of rupees, ${ }^{311}$ a chronogram was composed:

307 Baburnama, Mano, p. 483. Thackston, tr., p. 644.

${ }^{308}$ Asher, "Architecture," p. 209.

309 Abdul Rehman, "Garden Types in Mughal Lahore," Gardens in the Time of the Great Muslim Empires, 1997, p. 166.

${ }^{310}$ Ibid., p. 164

${ }^{311}$ Inayat Khan, Shah Jahan Nama, p. 298. 
When Shah Jahan, the King Defender of the Faith, laid out the Shalimar in becoming style, I asked the date of the foundation from the doorkeeper of Paradise. He answered saying, "This is the example of the highest Paradise."

The most famous Mughal gardens of Lahore, the Shalimar Bagh of Shah Jahan and the Bagh-i Jahangiri (a garden constructed for the emperor Jahangir), are the only Mughal gardens still intact of the city's original fifty, although even they have not been maintained in their original condition.

Almost one hundred years after Babur and his soldiers began to landscape the banks of the Jamuna River, the emperor Jahangir affirmed the continued importance of the Timurid garden to the Mughal dynasty. On a nostalgic journey to Babur's former capital, he reverently toured Kabul's gardens: the Shahr Ara (adornment of the city); the Mahtab (moonlight); the Orta (middle); another garden nearby which had been built by Jahangir's grandmother, the Suratkhana; and the largest garden in Kabul, the Chaharbagh, writing afterwards, "I don’t recollect that I ever walked so much."313 Jahangir spent much of his time in Kabul at the Shahr Ara Bagh, which he claimed was so delicate "that to put a shod foot on its surface would be tasteless and unnatural." Under its cherry trees he conversed with his companions and the ladies of his court and organized noodle- cooking sessions, archery contests and dances for Kabul's students. Spying "an excellent piece of ground" nearby, he ordered the construction of yet another

\footnotetext{
${ }^{312}$ Quoted in, R.E.M. Wheeler, Five Thousand Years of Pakistan, London: Royal India and Pakistan Society, 1950, p. 87. The chronogram was a poem, the letters of which could be added together to indicate the date of the garden's construction. Similar chronograms were written to celebrate and reflect the date of notable events, including the accession of Jahangir (see chapter three for example).

${ }^{313}$ Jahangirnama, pp. 62-63.

${ }^{314}$ Ibid.
} 
garden, with a "beauty and elegance that would have no equal in all the world. I named it Jahanara, World Adorner., 315

Those Mughal gardens specifically designed as the settings for imperial tombs remain the best known, perhaps because the fabulous architecture of the Mughal mausoleums has been more consistently valued, and certainly has been better able to withstand centuries of neglect, than the more elusive garden plantings. In classic chaharbagh format, Mughal tomb gardens contained four- way water channels and complex formal plantings, with the imperial mausoleum replacing the traditional garden kiosk or pavilion at the garden's base. The first Mughal garden tomb was that of Humayun, built during the reign of Akbar under the supervision of Humayun's Persian widow, Hamida Begim. As the first construction of its type on the subcontinent (it was finished in 1571), it is considered a major development in Indo- Islamic architecture. While many scholars have pointed out the Persian influences obvious in the architecture of Humayun's tomb, it behooves us to remember that Hamida Begim was not simply Persian but was in fact from Khurasan, the former heartland of Timurid rule and Timurid culture. As such, she cannot be described as bringing foreign influences to the Mughal aesthetic. ${ }^{316}$ In fact Humayun's tomb was topped with a classic Timurid dome of white marble, a Persianate style first developed by the Ilkhanids and brought to perfection at the imperial courts of Mawarannahr and Khurasan. Yet in a nod to its Indian setting, the tomb's dome was set on a heavy red sandstone base and its roofline topped with an idiosyncratic series of Indian chatris, small and ornate square cupolas. The physical setting for Humayun's

\footnotetext{
${ }^{315}$ Ibid.
} 
tomb returned to the classically Timurid: a large and gracious chahar-bagh with carefully geometric waterways and plantings (although today it consists of a scruffy mowed lawn split by dry concrete water channels, visited by flocks of tiny green parrots and the occasional white heron).

Humayun's tomb is considered to have been the prototype for the Taj Mahal, the most famous of all Mughal architectural monuments, its tomb and garden complex built by the Mughal emperor Shah Jahan to honor his wife, Mumtaz Mahal. Yet the enormous and delicate white marble dome of the Taj expresses an architectural aesthetic far more Persianate (perhaps Shah Jahan's imagined fantasy of a classic Persian dome) than that of Humayun's Timurid- Hindu fusion. Surely the Taj's inheritance was drawn not so much from Humayun's dome as from their common setting at the base of a beautifully landscaped Timurid chahar-bagh..$^{317}$

Other almost equally flamboyant Mughal imperial garden- tombs include that of the Khan-i Khanan in Delhi, Akbar's mausoleum at Sikandra outside of Agra, Jahangir's tomb at Shahdara in Lahore, the fabulous tomb of the I'timad al-Dawlah (father-in-law to Jahangir) in Agra, the tomb of Aurangzeb's wife in Aurangabad, and the tomb of Nawab Safdar Jang (an eighteenth-century Mughal vizier) in Delhi. ${ }^{318}$ While they all reflect varying degrees of Timurid influence, they share a willingness to engage indigenous architectural styles and motifs; none replicates a purely Timurid model. Akbar's tomb,

\footnotetext{
${ }^{316}$ See Gavin Hambly, Cities of Mughal India, New York: G.P. Putnam's Sons, 1968, p. 41, where he asserts that the tomb "exemplifies the alien Persian element" and that "Iran... (was) the main inspiration for this great mausoleum."

${ }^{317}$ Dale, Garden, p. 186. Shah Jahan's architectural impulses were much more Persianate than those of his predecessors, whose imperial architectural projects he regularly renovated in a distinctly delicate Persian style, in white marble adorned with pietra dura. See Ebba Koch, The Complete Taj Mahal, London: Thames and Hudson, 2006.

${ }^{318}$ Hambly, Mughal Cities, p. 41.
} 
the design of which, though originally planned by Akbar, was deeply influenced by Jahangir after his father's death, is wildly original in its blend of Persianate, Central Asian and Indian styles. From the time of their arrival in India, the architecture of the Mughal kings was remarkably innovative and adaptable, evoking Timurid and Persian precedent yet evolving fascinating interpretations and syntheses of local and imported design characteristics.

In fact, the single common factor that links all of these Mughal tombs and marks them as indisputably Timurid is their setting in traditional chahar-baghs. It has been suggested that no matter how glorious the buildings, perhaps the original aesthetic had intended the garden to take center stage in these constructions. ${ }^{319}$ No Mughal garden exists today in its original state (in part because of the vast amounts of water necessary to sustain the lush and lavish landscaping), but a painting of Jahangir's funerary garden, the Bagh-i Dilkusha in Lahore, reveals dense plantings which were regularly flooded to achieve "a swirling mass of flowers, fruit trees and fountains, situated at different levels." ${ }^{320}$ In this context the white domes of Mughal tombs would be exposed in tantalizing glimpses through tree branches, fruits and flowering vines, rather than sitting completely exposed with the blunt force imposed on them by a modern barren landscape of carelessly mowed lawns.

How can we best understand the Mughals' willingness to adapt the wellestablished Timurid architectural tradition to include what were, for the conquerors, previously unknown construction techniques and styles? It has been suggested that the physical structure of Humayun's tomb, the most influential Mughal architectural effort in

\footnotetext{
${ }^{319}$ James Dickie, “The Mughal Garden: Gateway to Paradise," Muqarnas, vol. 3 (1985), p. 130.
} 
India, was intended as an illustration and affirmation of the Mughal genealogical legacy, and perhaps this explanation can be applied to many of the Mughal constructions. Described as “an architectural manifesto,"321 Humayun's tomb was carefully and selfconsciously constructed as an imperial conceit linking Akbar, the reigning monarch, with the architecture of his Timurid forefathers, while the indigenous construction materials (particularly the ubiquitous red sandstone) and the motif of the roofline chatris made a public statement that linked the emperor to his Indian empire. In this way "past and present are united in a single building that is at once Timurid and Mughal, and thus Humayun is positioned as both descendant of Timur and progenitor of Akbar., ${ }^{, 322}$

The political use of architecture was a strategy that had been employed by generations of Timurids, and their Mughal descendants would not have hesitated to manipulate local and traditional architectural motifs and materials in their pursuit of an imperial image which could affirm their unassailable political lineage in a style acceptable to the diverse population of their new empire. Mughal architecture was constantly manipulated to evoke the profoundly important imperial legacy of the Timurid past, while convincingly asserting an authentic convergence with the traditions of the Mughals' conquest territories. The classical Timurid garden, on the other hand, perhaps because it was confronted by no recognizably comparable, competing, entrenched landscaping tradition on the subcontinent, remained in its beloved original form

\footnotetext{
${ }^{320}$ Ibid.

${ }^{321}$ Ebba Koch, "Delhi of the Mughals," Mughal Art and Imperial Ideology: Collected Essays, Ebba Koch, ed., New Delhi: Oxford University Press, 2002, p. 174.

${ }^{322}$ D. Fairchild Ruggles, "Humayun's Tomb and Garden: Typologies and Visual Order," in Petrucciolo, ed., Gardens, p. 174.
} 
throughout the centuries of Mughal rule, an affirmation of Mughal imperialist ambitions and a long- lived remnant of an unreconstructed Timurid aesthetic in India.

\section{Recognition of the Timurid Legacy of the Mughals}

Mughal obsession with the Timurid lineage was well known, and rival rulers were quick to make use of it in diplomatic exchange. Naqshbandi ambassadors from the Uzbek courts in Harat and Samarqand carried lines of poetry penned by Babur himself, offering them as a successful entrée to Jahangir's innermost court, along with assurances of continued Naqshbandi support for "the members of this dynasty." extemporaneously composed a matching quatrain, "My love for you is greater than ever, and the memory of you, O Dervish, is good fortune/ As happy as my heart is with good news of you, we are happier that your kindness is more than ever," and sent it back to Khwaja Hashim Dahbidi in Samarqand with a thousand mohurs. ${ }^{324}$

The Emperor Jahangir was perhaps most highly susceptible among Mughal kings to dynastic memorabilia. In his third regnal year, Jahangir was given a drinking vessel by Munis, son of Mihtar Khan, whom Jahangir describes as "one of the old servants of this dynasty (az ghulaman-i qadimi in dawlat)," in that he had in the past served Humayun and Akbar. The cup had been crafted of white jade in Samarqand, ca. 1447-49, with the name of the artist's patron, Timur's grandson, Ulugh Beg Guregen, carved along the exterior rim. Jahangir had his own name and that of his father, Akbar, inscribed along the lip of the cup and described the event in his memoir. ${ }^{325}$ When he was presented with a

\footnotetext{
${ }^{323}$ Jahangirnama, p. 173. Thackston, p. 182.

${ }^{324}$ Ibid.

${ }^{325}$ Ibid., p. 83. The white jade Ulugh Beg cup is now on display at Museu Calouste Gulbenkian, Lisbon.
} 
collection of Humayun's writings, "containing some prayers, an introduction of the science of astronomy, and some other unusual matters," he claimed to feel "greater elation than I ever remember experiencing before.... As God is my witness, no gift of the utmost rarity or gem of the highest value could equal it in my view.",326

Diplomats returning from the Safavid court of Shah Abbas brought with them a fabulous painting of Timur pictured in battle against the Delhi sultan, Ilutmish Khan. Portrayed were two hundred and forty "likenesses of his mighty sons and grand amirs who participated in the battle."327 Jahangir describes tense negotiations in which his ambassador was able "through his auspicious ascendant" to convince Shah Abbas, who "knew how intent we were upon such rarities," to allow the picture to leave Iran for the Mughal court. ${ }^{328}$ On the other hand, Portuguese visitors to his imperial court also offered Jahangir a portrait of Timur, painted, he was told, by a Byzantine Christian present during Timur's conquest of Ottoman Anatolia. A doubtful Jahangir felt the portrait must be a fake, for it "bore no resemblance to his royal descendants." He wistfully added, "If this had been true, in my opinion there could not have been a more valuable object in my possession., 329

In a period of tense haggling over control of Qandahar, the Safavid Shah Abbas sent as a gift to Jahangir a magnificent ruby which had originated in the treasury of Timur's grandson, Ulugh Beg, and was inscribed with his name, that of his father, Shahrukh, and his grandfather, Timur. "Because it had the names of my ancestors (nam-i ajdad-i man) on it," wrote Jahangir, "I took it as an auspicious blessing (tayamuna $u$

\footnotetext{
${ }^{326}$ Ibid., pp. 302-3. Thackston, tr., p. 299.

${ }^{327}$ Ibid., p. 323.

${ }^{328}$ Ibid.
} 
tubarrugan bar khud mubarak girafte). ${ }^{, 330}$ He proceeded to have his own name, Jahangir Shah ibn Akbar Shah, added to the ruby's imperial silsilah and presented it to his son Khurram while determinedly clinging to Qandahar, if for only a few more years. ${ }^{331}$ When Khurram ascended to throne as the Emperor Shah Jahan he instructed the court ateliers to set the Ulugh Beg ruby in a fabulous, jewel encrusted chair, which later became known as the Peacock Throne. ${ }^{332}$ "Among the precious stones [on the new bejeweled throne] was a ruby worth a lac of rupees, that Shah Abbas Safavi had sent to the late emperor, on which were enscribed the names of the great Timur Sahib Qiran....”333

\footnotetext{
${ }^{329}$ Jahangir, Waki at- $i$ Jahangiri, E \& D, VI, p. 320.

${ }^{330}$ Jahangirnama, p. 369.

${ }^{331}$ The Safavids successfully retook Qandahar in 1622.

${ }^{332}$ Abdul Hamid Lahauri, Badshahnama, E\&D, VI, p. 46.

${ }^{333}$ Ibid. See also Inayat Khan, Shah Jahan Nama.
} 


\section{CHAPTER 4}

\section{WOMEN IN TIMURID- MUGHAL DYNASTIC POLITICS}

There were other, more personal, components of the Timurid legacy which were equally profound in the development of the Mughal imperial culture, including those traditions responsible for defining the various roles made available to Mughal women. These cultural ideals migrated to the subcontinent with the refugee Timurids, forming the basis upon which Mughal family relationships remained predicated for centuries. Women of the Turco- Mongol nomadic cultural tradition had led less circumscribed lives than their contemporaries in the Perso- Islamic world, and their public participation in important political and social institutions was not dramatically cut back with the Islamization of the tribes. ${ }^{334}$ It is considered for the most part the natural requirement and result of their nomadic origins that elite women of Turco- Mongol Timurid Central Asia enjoyed a more public position and a higher degree of independence than those of other Muslim societies.

In the Timurid period, elite Central Asian women retained the right to participate in tribal qurultays, act as regents for their minor sons, and perform conspicuous roles in

\footnotetext{
${ }^{334}$ Recent comprehensive studies of Central Asian women in the pre- modern period include Beatrice Manz, "Women in Timurid Dynastic Politics," Women in Iran from the Rise of Islam to 1800, Guity Nashat and Lois Beck, eds., Champaign-Urbana, Illinois: University of Illinois Press, 2003, pp. 121- 139; Maria Szuppe, "Women in Sixteenth Century Safavid Iran," in same volume, pp.140- 169, and Priscilla Soucek,
} 
public ceremonies. The memoirs of the Spanish envoy to Timur's court, Ruy Gonzales de Clavijo, confirm that at the time of his visit, in 1404, the royal court had not developed a closed harem, but instead many court women lived in a series of unwalled gardens just outside of the capital city of Samarqand. As with the amirs and princes of the court, and Timur himself, the women resided in pavilions of silk and embroidered tapestry, and "all of these enclosures aforesaid were occupied either by the wives of Timur, or by the wives of his grandsons, and these princes and princesses have their abode therein, as does also his Highness likewise, both summer and winter."${ }^{, 335}$ In their luxurious garden encampments, and later in their own garden palaces, women of the Timurid court entertained their own guests, feasted and drank alcohol in company with men, and seem to have veiled with the thinnest of gauzes that allowed the observer to see their features clearly. ${ }^{336}$ Timurid women were responsible for arranging major dynastic events, such as marriages and royal welcoming committees, and participated in diplomatic exchanges alongside amirs and princes.

The public position of Timurid court women may not have been due solely to nomadic tribal tradition but perhaps also to the critical role women played in the establishment of Timurid dynastic legitimacy. ${ }^{337}$ As we have seen, Timur and his sons and grandsons married strategically into the Chingizid family, resulting in what Beatrice Manz describes as an "in-law dynasty." 338 Even after the Timurid lineage had developed its own high polish of political charisma, the ability of a Timurid prince to seize power

\footnotetext{
"Timurid Women: A Cultural Perspective," Women in the Medieval Islamic World, Gavin Hambly, ed., New York: St. Martin's Press, 1998, pp. 199- 226.

${ }^{335}$ Clavijo, Embassy, p. 243.

${ }^{336}$ Manz, "Dynastic Politics," p. 124 and Clavijo, Embassy, pp. 244-8.

${ }^{337}$ Manz, "Dynastic Politics," p. 121.
} 
was not considered sufficient justification for him to retain it. When a new branch of the dynasty managed to wrest control, the successful claimant carefully married women of the Chingizid line, as well as the Chingizid descendants of his conquered Timurid rivals, in order to further enhance the legitimacy of his rule, as in the case of Timur's grandson Abu Sa id (1424-1469), who seized power from the ruling lineage of Shah Rukh in the 1450's, married a Chingizid wife, and assumed Timur's regnal title of Guregen, son- inlaw. $^{339}$

Apart from the careful establishment of legitimacy through marriage into the Chingizid line, the Timurids married into the families of their followers, in order to firm alliances or guarantee political loyalty. Chingizid and Timurid women of royal lineage were critical figures in the legitimization of power, so that even a married woman retained an independence of identity, which allowed her to express continued loyalty to her own family line. Maternal origins were reflected in the status of princes, and Timurid children were often given names from their matrilineal line, which had a permanent claim on their loyalty and critical role in shaping their identity, as well as that of their mothers. It seems possible, therefore, that the social and dynastic role played by royal women in supplying and protecting the ruling family's political charisma may therefore have been a factor in the degree of authority and power held by elite Timurid women.

That this can be seen as a particularly Turco- Mongol inheritance is confirmed by a study of the conditions of Safavid women in the period of the Turcoman Qizilbash ascendancy in Iran, which affirms their similarly important public role, residence in a relatively loose harem system, public use of the lightest of veils, and participation in the

${ }^{338}$ Ibid., p. 122. 
legitimation of the dynasty through strategic matrimonial alliances with tribal groups and the religious elite. ${ }^{340}$ This has been attributed to the Safavid inheritance of Timurid traditions through descent from the Turkish Aqquyunlu tribes, whose women similarly enjoyed an important public role. The Aqquyunlu queen mother, Saray, acted in a diplomatic capacity for her ruler- son, Uzun Hasan, traveling to Cairo in 1466 to meet with Mamluk rulers in the political interests of the Aqquyunlu. ${ }^{341}$ Not incidentally, matrimonial kinship ties to Uzun Hasan supplied the Safavid founder, Shah Ismail, with an enhanced degree of political legitimacy.

Of particular note, the gradual suppression of the independence of Safavid royal women coincided with the loss of Turcoman Qizilbash power and the increasingly conservative religious leanings of the Safavid family after the mid- sixteenth century. ${ }^{342}$ As the Turco-Mongol cultural influences faded from Safavid dynastic tradition and the empire grew more sedentary and conservative, women of the Safavid elite lost much of their social and political influence. In contrast, the Mughal dynasty of India, direct descendants of the Timurids of Transoxiana, clung relentlessly to their Turco- Mongol identity during their centuries in South Asia, and the importance of their lineage in the establishment of Mughal dynastic identity and political legitimacy caused them to reject the dilution of Timurid political and social traditions which had occurred in other

\footnotetext{
${ }^{339}$ Ibid.

${ }^{340}$ Szuppe, "Safavid Iran," pp. 140- 169.

${ }^{341}$ John Woods, The Aqquyunlu: Clan, Confederation, Empire, Salt Lake City: University of Utah Press, 1999, p. 95.

${ }^{342}$ Szuppe, "Safavid Iran,” p. 162.
} 
contemporary Turco- Islamic empires, including those related to the position of dynastic women. ${ }^{343}$

\section{Babur and the Late Timurids}

One hundred years after Clavijo had feasted and drunk alcohol with Timur's wives and daughters-in-law, Babur wrote in astonishment at a woman's request to be allowed to join his drinking party. Babur wrote that he had never seen a woman drink before and, out of curiosity, he agreed to invite her. The experience was not a success; the woman, Hulhul Anika, became aggressive and Babur "got rid of her by feigning drunkenness" (akhir uzumni mastliqqa salip khilas buldum). ${ }^{344}$ He did not repeat the experiment.

Babur's experience may reflect the reality of late Timurid courtly custom or the unstable conditions of his constant warring. His writings confirm Babur as an intensely homosocial character whose greatest pleasure seems to have been a raucous revel in the company of other men, well oiled with copious amounts of alcohol, majun (a mild opium-based concoction) and poetry, but his descendants tended to revert to the earlier Timurid pattern; as we shall see, the emperors Humayun, Akbar, Jahangir and Shah Jahan, as well as many of their later descendants, commonly included women of the imperial harem as companions in hunting parties, court banquets and military campaigns.

While Babur's writings may be interpreted to suggest shifts in the culture of the increasingly sedentarized Central Asian late Timurid society, he confirms the continued dynastic importance of maternal lineage, citing, for example, Firuza Begim, the mother of

\footnotetext{
${ }^{343}$ See Balabanlilar "Lords of the Auspicious Conjunction: Turco- Mongol Imperial Identity on the Subcontinent," The Journal of World History, Vol. 18, No. 1 (2007) pp. 3- 39.
} 
Mirza Husayn Bayqara, through whom Bayqara "was a grandson of Timur Beg's grandson Sultan Husayn and of Miranshah Mirza, and was thereby noble on both sideshe was a born king" (karimu'l tarafayn edi-- asil badshah edi). ${ }^{345}$ It was Sultan Husayn Bayqara's double line of descent from Timur that Babur, himself half- Timurid and halfChingizid, so admired, obviously unconcerned that this enhanced political legitimacy sprang in part from Husayn Bayqara's maternal lineage. Furthermore, as with the earlier Timurids, princely loyalties were attached to both the maternal and paternal lines; Babur's mother was of Chingizid descent and it was this relationship which allowed Babur to seek refuge with his Mongol uncles and to call on the military assistance of Mongol warriors who owed allegiance to his royal mother. "In my mother's service," wrote Babur, "were fifteen hundred to two thousand from the Mughul tribes" (ming besh yuz iki ming ka mugul ulusi din bar edi). ${ }^{346}$

The participation of respected women in Timurid dynastic councils was maintained throughout the Timurid period; when Babur's position as ruler of Ferghana was threatened shortly after his father's death, his supporters met with his grandmother, Esan Dawlat Khanim, in order to plot their response. "For strategy and tactics" (ra'y ve tadbir), Babur wrote admiringly, "there were few women like my grandmother Esan Dawlat Khanim. She was very intelligent and a good planner. Most affairs were done by her council." ${ }^{347}$ Captured by enemies in battle on four occasions, Esan Dawlat Khanim had already proven her fortitude and strength of character. Taken as spoils of war from her defeated husband, Babur's grandfather Yunus Khan (d. 1487), and given in marriage

\footnotetext{
${ }^{344}$ Baburnama, Mano, p.392.

${ }^{345}$ Ibid., Mano, p. 253.

${ }^{346}$ Ibid., Mano, p. 96.
} 
to a liegeman of the victorious Shaykh Jamal Khar, "her silence was taken for consent." On their only night together, however, the Khanim's attendants "seized him, brought him down with the begim's help, and killed him with knives, awls and spindles." When Esan Dawlat Khanim was brought before her captor she defended the murder, asserting, "I am the wife of Yunus Khan. Does Shaykh Jamal Khar give me to another? Is this allowable in Mohammedan law and the Muslim religion? I did not want [the murdered liegeman] Khwaja Kalan's filthy hand to touch my pure hem.... He deserved killing." Not only did the murder go unpunished; Esan Dawlat Khanim gained respect for her act of selfprotection and was returned to her husband unharmed and "with all honor." ${ }^{348}$ Her daughter, Babur's intrepid mother, Qutlugh Nigar Khanim, was her son's constant companion, traveling with him and suffering at his side when his fortunes were in decline. "She was with me," he wrote, "through much of my vagabondage and the interregnum (qazaqliqlarda ve fatratlarda)." 349

Babur's choice of wives reflects the marriage patterns of earlier Timurids; marital considerations carefully weighed political alliances with rivals or with regional royalty of a more charismatic lineage. Himself a Sunni Muslim, Babur in 1506 married a Shi ${ }^{i}$ woman, Maham Begim, who was related to that paragon of Timurid royalty, Husayn Bayqara. In 1519 Babur made a diplomatic marriage to an Afghan of the Yusufzai tribe, Bibi Mubarika, whose close ties to her family and tribe assisted her new husband in developing better relations with troublesome competitors. In a perhaps apocryphal legend Bibi Mubarika is described as the protector of her entire tribe, petitioning her new

\footnotetext{
${ }^{347}$ Ibid., Mano, p. 37. Thackston, tr., p. 49.

${ }^{348}$ Mirza Haydar Dughlat, Tarikh, p. 50.

${ }^{349}$ Baburnama, Mano, p. 16.
} 
husband to "think that the whole Yusufzai tribe is enfolded in my skirt, and pardon their offenses for my sake." To this Babur replied, "I forgive the Yusufzai all of their offenses in your presence, and cast them into your skirt. Hereafter I have no ill feeling to the Yusufzai. ${ } 350$

Having created a safe haven in India, Babur sent messengers to Kabul, carrying gifts of jewels and dancing girls to his sisters, daughter, aunts, cousins, and wives, along with a royal decree that they immediately set out within the week to join Babur in Agra, where only five years later the women of the Timurid dynasty would gather to celebrate Humayun's Mystic Feast. On news of their arrival, while the long train of women, children, servants, guards and warriors was still four miles outside Agra, Babur "did not wait for a horse to be saddled, but set out on foot" to meet his long anticipated family. ${ }^{351}$

It has been noted that throughout the reigns of Babur and his son, Humayun, "there seems to have been no distinction between the public and the private-in the sense of the physical separation of the court and the harem.."352 The reason for this is obvious in the life histories of these rulers; both Babur and Humayun spent many years traveling with their respective retinues, more often in the role of warring chieftain than ruling emperor, either in search of conquest or in flight from invading Uzbeks, Afghans or rapacious relatives. Their peripatetic lives prevented either of them from developing a set of formal court rituals that might have resulted in the separation of a women's space, in

\footnotetext{
${ }^{350}$ Ruby Lal, unpublished dissertation, "Historicizing the Harem,” John Hopkins University, 2004, Index: An Afghan Legend, p. 176 and p. xl. Italics mine. It is of interest to note that modern Turkish contains the idiom "eteğine sigınmak." While the literal translation of this is "to seek refuge in a skirt," it lacks the negative connotations of the English idiom, "to hide behind a skirt" - the modern Turkish version refers simply to a request for assistance.

${ }^{351}$ Humayunnama, p.17.

${ }^{352}$ Lal, "Historicizing the Harem," p. 29.
} 
the unlikely event that either of them been inclined to establish a more traditional harem. Humayun grew to adulthood during his father's empire- building years, a time of enormous vulnerability and instability. It is notable that during his reign the public and political role of Mughal women continued in the pattern of their Timurid ancestors.

On the anniversary of Humayun's accession to the Mughal throne (r. 15301556), only a few years after his father's conquest of northern India, the Mughal royal elite united for a magnificent gathering known as the "Mystic Feast." The emperor's sister, Gulbadan Begim, wrote of the celebration in her memoir, recording the names of thirty- six of the ninety-six women who attended the Mystic Feast, all of whom were members of the extended Timurid royal family. The clearly fascinated Gulbadan Begim describes a startlingly unconventional couple who sat among the honored guests at the imperial celebration: two women, Shad Begim and Mihrangaz Begim, who "had a great friendship for one another, and they used to wear men's clothes and were adorned by various accomplishments, such as the making of thumb- rings and arrows, playing polo, and shooting with the bow and arrow. They also played a great many musical instruments." 353

The two women were cousins, both granddaughters of Sultan Husayn Bayqara. Shad Begim was the daughter of Bega Kilan Begim and Haydar Bayqara, and had at one time been married to the Timurid Adil Shah. Mihrangaz Begim, daughter of Muzaffar Husayn Mirza, had been forcibly married to Ubaydullah Uzbeg when Harat was taken from the Timurids by the Uzbek conqueror Shibani Khan in June 1507 (913 AH), ${ }^{354}$ after

\footnotetext{
${ }^{353}$ Humayunnama, p. 33. BA, pp. 120-1. ("Bisyar dust midashtan u libas-i mardane mipushidand u banaw' $i$ hunarha arasi hem chu zahgiri tarashi u chaugan nazir u tir andazi u aksarsazha mi nevakhtand.") ${ }^{354}$ Ibid., BA, p. 262.
} 
which hurried wedding, according to an eyewitness, the remaining residents of the royal harem were returned to Harat and subsequently robbed of their jewels. ${ }^{355}$ There is no record of the arrival in India of Mihrangaz and Shad Begim, only that they were members of the Timurid refugee elite who celebrated dynastic survival and sovereignty at the new Mughal court in Agra.

Gulbadan Begim's brevity regarding the two guests is frustrating, leaving us with more questions than answers, yet our sources on the early Timurid years in India are extremely few and Gulbadan Begim's memoir is surely one of the most significant among them. Her undisguised interest in these women suggests that they did not represent a social norm; when composing her memoirs years after the Mystic Feast, our author remembered and made note of their idiosyncrasies, while no other woman among the guests receives more mention than that of name and position within the imperial household. Yet for all their conspicuous unconventionality, it is noteworthy that these uncommon women were not treated as eccentric social outcasts but instead were honored guests at the imperial Mystic Feast. Although they had certainly circumvented convention and may have in fact represented an extreme, the freedom of action displayed by the unorthodox Shad Begim and Mihrangaz Begim demonstrates the high degree of independence available to women of the Timurid-Mughal elite. Their situation was not entirely unique, nor did it indicate a temporary shift in values due to the wrenching political changes and social transformations of early Mughal empire- building. Instead, their example illustrates what was a cohesive and consistent pattern in the social fabric of the Mughal dynasty, whose accommodation of independent elite women in early modern

${ }^{355}$ Ibid., p. 263. Khwandamir, Habib al- Siyar, in Thackston, CP, p. 232. 
Islamic India can be firmly sited in the traditional rights and privileges of the Mughal dynasty's Turco- Mongol Timurid ancestors

There is no indication that either woman gained her independence of action, influence or power through age, maternity, or marriage, although Mihrangaz may have been esteemed among the exiled Timurids for surviving and escaping an Uzbek marriage conquest. Babur's own sister, Khanzada Begim, was revered for having accepted a forced marriage to Shibani Khan, although her circumstances were unique in that she married in order to protect Babur in his escape from Uzbek overrun Samarqand. ${ }^{356}$ It was due to their own elite lineages, as princesses of the Timurid dynasty, grand- daughters of the famed Timurid prince Husain Bayqara of Harat, that these women were seated at the Mystic Feast and given the right to live an unconventional life, expressed in those attributes found most compelling by Gulbadan Begim: the rejection of marriage, wearing men's clothing, playing polo and manufacturing archery equipment. Public displays of gendered unconventionality did not turn Timurid princesses into pariahs.

Far from inhabiting an "enclosed" or "domestic" space, royal women displayed consistent involvement in the military/ political concerns of the Timurid dynasts, as can be seen in Humayun's response to his military rout outside of Kabul by the armies of his brother Kamran Mirza in 1549, when Humayun requested aid from his cousin's wife. "In a few days - a very short time--- the begim had given horses and arms to some thousands of men. She herself superintended and took thought and came with the troops as far as the pass. From here she sent them forward, and while she went back they went on and 
joined the Emperor." ${ }^{, 357}$ In his early years on the throne, Humayun's paternal aunt, Khanzada Begim, who had survived the Uzbek conquest of Samarqand, two forced marriages, war, flight, capture and migration to her brother's territories in India, served as the principal lady of Humayun's court and was given the title Padshah Begim, or Lady King, publicly affirming and sanctioning her powerful influence at the Mughal court. In classic Timurid style, the attempted reconciliation of Humayun and his brothers, who had rejected his sovereignty and claimed regional autonomy, required Khanzada to play the role of negotiator among the rival princely courts, although her intervention was ultimately unsuccessful. Even more dramatic was her journey from Sind to Qandahar to negotiate safe passage to Safavid territories for Humayun and his desperate band of refugees. ${ }^{358}$

Even in periods of extreme political unrest, Humayun, Babur and their Timurid ancestors so valued the companionship of women and children that families were sometimes carried into dire peril. Plentiful examples exist of Timurid-Mughal women and children who, remaining close to the center of power, were thus made deeply vulnerable. In Babur's desperate flight from Samarqand, which he had only recently conquered, his mother and one serving woman were able to flee the city with him but his sister and other women of the household were left behind to the conquering Uzbeks. Even when a safe haven was available for non- combatants, as in Babur's Kabul, Timurid- Mughal women and children went to war with their men; when Babur mobilized a third attempt to seize Samarqand, he took with him "his people and wives

\footnotetext{
${ }^{356}$ See chapter two for a more complete list and discussion of the circumstances of these conquest marriages.

${ }^{357}$ Humayunnama, p. 91. Bev., tr., p. 195.
} 
and children." Indeed, it was typical to keep the "household" nearby; while under direct threat from Kamran Mirza and his followers, Humayun included his wife, aunts and cousins, "Bega Begim, Hamida Banu Begim, Mah- chuchak Begim, and many others," on a pleasure jaunt which ended in an assassination attempt on the emperor. ${ }^{359}$ When Humayun led his armies to Chausa, near Varanasi, in June of 1539, to confront the Afghan challenger Shir Khan (later Shir Shah), much of the extended royal family left the safety of Agra's palaces and joined the march. In the rout that followed, Timurid women and children who had survived the Uzbek invasion of Mawarannahr and the dynasty's subsequent migration to India were killed, drowned in the river in the chaos of battle. Humayun later mourned the loss of his eight-year-old daughter, Aqiqa, at Chausa, saying, "I have been consumed by a hundred thousand regrets, and have asked myself, 'Why did I take her with the army?",360

Having lost Babur's territories in India, Humayun and his young Persian wife went into flight so frenzied that their fourteen-month old son, Akbar, was left behind. In their exile in Safavid Iran royal hunting expeditions included the Turcoman Safavid Shah's armed and mounted sister. While India's Timurids fled in all directions from the advancing Afghan armies, Humayun's aunt, Bibi Mubarika, bravely remained behind in Agra to protect Babur's grave from insult, after which the respectful Afghan leader, Shir Shah Sur, graciously allowed her to accompany her husband's body to its permanent burial site in Kabul. ${ }^{361}$

\footnotetext{
${ }^{358}$ Humaynnama, Bev. introduction, p. 34.

${ }^{359}$ Ibid., p. 92. Gulbadan Begim explains her own absence from the trip, a hunting and sightseeing expedition, as being due to the illness of her son.

${ }^{360}$ Ibid., pp. 138-9. Aqiqa was Humayun's second child, born in Agra in 1531 by his wife Bega Begim.

${ }^{361}$ Ibid., BA, pp. 216-7.
} 
Women of the Timurid-Mughal world were neither veiled victims nor passive spectators. The early modern imperial family was an inherently political entity, with little allowance for, or expectation of, a separation between private and public worlds-how much more so in a family such as the Timurid-Mughals, with a long tradition of public political participation by women. All members of the family were aware that the fate of Timurid-Mughal women was tied to the military and political success of the dynasty, and as full partners in the business of empire- building their lives were exceptionally vulnerable. For little more than a decade during either of their adult lives did Babur (during his Kabul years) and Humayun (immediately following his succession to the Mughal throne) enjoy the stability which might have allowed them to establish an institutionalized palace life with some form of traditional harem system. These men and their families lived peripatetic lives and maintained highly mobile courts of dramatically shifting size and content, on the model of their Turco-Mongol forebears, in which the position of dynastic women was neither completely segregated nor hierarchical. Although constantly at risk of being caught up in the frenzy of conquest and defeat, the women of the Timurid- Mughal family remained companions and counselors, willing participants in the imperial project, living in close proximity to the center of power. When Gulbadan Begim used the word "haraman" to describe the women of Humayun's household, it is clear from the context that, far from describing the inhabitants of a separate and distinct physical space, she used the term solely to define an intimate family relationship. ${ }^{362}$

\footnotetext{
${ }^{362}$ Ibid.
} 


\section{The Imperial Harem as an Akbari Institution}

The nearly fifty-year reign of Humayun's son, Akbar (1542- 1605), marked a dramatic transition in the character of the Mughal court. This long period of relative stability allowed for the entrenchment of Mughal sovereignty in India and the independent development and refinement of those imperial institutions which had previously, more of necessity than design, been piecemeal and ad hoc. A sophisticated system of taxation, the ranking and remuneration of imperial officers, the minting of coins, the structure of the military-- all was creatively refined and formalized by Akbar and his counselors. Additionally, the physical structures of the entirely new Mughal capital built by Akbar at Fatehpur Sikri were a public reflection of the increased control and institutionalization of the imperial project. In a period of such careful attention to the development and formalization of court practices, as well as the self- conscious construction and presentation of the imperial image, it should come as no surprise that the imperial harem was the recipient of similar attentions. According to Abu'l Fazl, "The large number of women--- a vexatious question even for great statesmen--- furnished his majesty with an opportunity to display his wisdom.... His Majesty has made a large enclosure with fine buildings inside. Though there are more than five thousand women he has given to each a separate apartment. He has also divided them into sections, and keeps them attentive to their duties.... Thus, as in the imperial offices, everything here is also in proper order." ${ }^{363}$ Abu'l Fazl carefully enumerated the "sufficiently liberal" stipends and salaries of women at the Mughal court, from servants to highborn elites,

\footnotetext{
${ }^{363}$ Abu'l Fazl, AA, I, pp. 45- 7. The five thousand women referred to by Abu'l Fazl refer, of course, not only to the emperor's wives but also to Akbar's many Timurid aunts and cousins, as well as maidservants,
} 
described the "peculiar, imperial stamp" with which the harem grants were marked, and mentioned the "sober and active" women who guarded the harem, the most trustworthy of which guarded the apartments of the emperor himself. ${ }^{364}$

There is no question that the conditions of life for Mughal women changed during Akbar's increasingly regulated and ritualized reign, but how deeply were these changes felt? ${ }^{365}$ Did Akbar effect the transformation of the traditional position of Timurid dynastic women? As one might expect, the writings of Akbar's confidant and ideologue, Abu'l Fazl, suggests that the formalization of imperial court practices led to the establishment of a more conservative and isolated harem system than the Mughals had previously known, describing the construction of a new private, interior world of women at Fatehpur Sikri, from which the public world of politics and commerce was carefully excluded. As spokesman and interpreter of the Akbari Mughal imperium, however, Abu'l Fazl projected a highly idealized vision, not always accurate in its description of Mughal realities, anxious to conflate Mughal rule, and Akbar's in particular, with the sacral and miraculous. In reality, actions by and for the women of the Mughal dynasty seem to argue against Abu'l Fazl's vision of a private interior women's space at the court. Traditional Timurid family roles were not to be so easily dislodged or modified.

For example, so public a role was taken by the women of Akbar's court that when Akbar's half-brother, Muhammad Hakim Mirza, governor of the Mughal province of

female harem guards and the rest of the enormous retinue of women required by an extended imperial family.

${ }^{364}$ Ibid. p. 47. For a more extensive and fascinating commentary on the use of women guards in Indian royal courts, see Gavin Hambly, "Armed Women Retainers in the Zenanas of Indo- Muslim Rulers: The Case of Bibi Fatima," Women in the Medieval Islamic World, Gavin R.G. Hambly, ed., New York: St. Martin's Press, 1998, pp. 429-468. His article positions the institution of women guards in a historically South Asian context, as early as the $4^{\text {th }}$ c. B.C. court of the Mauryas. 
Kabul, rebelled against Akbar in 1581, both the emperor's mother and his sister were officially appointed governors of Mughal territory. Akbar left his mother, Hamida Begim, in charge at the capital while he dealt with matters in the north and although Muhammad Hakim Mirza was eventually pardoned, Akbar appointed his half sister, Bakht al-Nisa Begim, as governor of the critical Kabul province. ${ }^{366}$

It was also during the reign of Akbar, in November 1575, that a large number of Mughal women, young and old alike, including an elderly Gulbadan Begim (who seems to have organized and led the expedition) and her granddaughter, as well as various wives, aunts, and nieces of the emperor, made their famous pilgrimage to the holy cities of Mecca and Medina. The emperor not only gave his permission, but also fully funded the pilgrims' travel: "The sovereign poured into the lap of each the money that they wanted and so made the burden of their desires light." 367 These adventurous Mughal women remained away from India for seven years, making the hajj four times. On their return to India the Mughal women were shipwrecked off the coast of Aden for a year and yet, on their rescue and eventual return to India, still insisted on making a pilgrimage to the Chishti shrine at Ajmer before returning to Fatehpur Sikri in March 1582. ${ }^{368}$

\footnotetext{
${ }^{365}$ This issue is explored by Ruby Lal in her unpublished dissertation and her recent book, both previously cited.

${ }^{366} \mathrm{Abu}$ Faz'l, AN, III, p. 536, and Montserrate, p. 153, as cited in Rekha Misra, Women in Mughal India (1526- 1748), Delhi: Munshiram Manoharlal, 1967, p. 31. Muhammad Hakim Mirza and Bakht al-Nisa Begim were full siblings, both children of Humayun's wife, Mah Chuchak Begim. It is interesting to note that in his pardon of the rebellious Muhammad Hakim Mirza Akbar was following a classic Timurid tendency; when their sovereignty and their lives were threatened by treacherous brothers, both Babur and Humayun refused to consider the advice of their followers and rid themselves permanently of their dangerous siblings. Rather, over many years and in the face of repeated betrayals, they blithely offered their brothers' their forgiveness and a series of benevolent pardons. See chapter five.

${ }^{367}$ Abu'l Fazl, AN, III, p. 205- 206. See also Bakhshi Nizam al-Din Ahmad, Tabiqat-i Akbari (E\&D) V, p. 391-2.

${ }^{368}$ This was the only hajj of its type in Mughal history, however. Akbar was insulted by the response of the Ottoman governors of the holy cities to the large number of Mughal women, who lingered overlong and
} 
Throughout the period of Mughal dynastic hegemony in India, elite women of the royal family, like their female ancestors in Transoxiana, built luxurious garden palaces for their own use, endowed the construction of not only mosques but also markets, caravanserais, and magnificent formal gardens, and arranged feasts and banquets to celebrate marriages, circumcisions and the annual solar and lunar weighing ceremonies of Mughal princes. A few notable examples include Nur Jahan's feast in 1617 in her own palace, to which she extended a formal invitation to the emperor, her husband Jahangir, and again in 1620 when she arranged another banquet to celebrate the completion of her garden-palace in Nur Sarai. ${ }^{369}$ It became common among elite women of the royal court to engage in trade; Miryam Makani, the mother of Jahangir, owned ships which plied the Indian Ocean and Arabian Sea, carrying spices, opium, and textiles for export and returning with perfumes, brocade, amber and ivory. The Portuguese capture of her ship, the Rahimi, led to the collapse of Portuguese- Mughal relations. ${ }^{370}$ Nur Jahan maintained a number of ships and dealt regularly with the English merchants, rather than the Portuguese with whom the Mughal court was often on bad terms, eventually becoming the official imperial protector of English goods. ${ }^{371}$

Women of the royal household supported imperial and religious institutions with endowments [awqaf] and gifts of land [madad-i ma'ash], assigned under their own seals, as well as the regular charitable distribution of clothing and money. In particular,

were finally asked to leave. Akbar's response was to discourage royal family members from making the hajj thereafter, although it remained a common site of exile for disgraced Mughal courtiers.

${ }^{369}$ Jahangirnama, p. 348. Thackston, p. 355.

${ }^{370}$ Letters Received By the East India Company, II (1613-15) p. 213. In fact nearly all members of the court elite dabbled in trade, not only women or members of the royal family. This was a common activity, without restrictions imposed by gender or caste, only those of ability and access.

${ }^{371}$ Sir William Foster, English Factory Records, (1618-1621), a calendar of documents in the India Office and British Museum, Oxford: Clarendon Press 1906, p. 148. 
Mughal women interested themselves in contributions to the trousseaus of young women of limited means. Nur Jahan is said to have supplied over five hundred girls with the money to marry respectably, while her husband allowed his father's foster sister, Hajji Koka, to recommend to him such deserving recipients of charity as the wives and daughters of deceased religious scholars. ${ }^{372}$ Shah Jahan continued the tradition, allowing the female head of the harem bureaucracy, who held the title sadr-i anas, to recommend deserving women. According to Inayat Khan's memoir, "Indigent women, according to their condition, are assigned grants of land, daily allowances or cash. Some unmarried girls, who owing to their poverty and indigence cannot afford the necessaries of marriage, receive according to family and condition, ornaments, clothes, money and other things which are indispensable for the wedding ceremony, and then are married to their equals. Every day in this most sacred palace, a considerable amount of money and ornaments are expended for this charitable purpose."

In public acknowledgment of their power and influence, Mughal noblewomen often received honorifics, in the model of the regnal and posthumous names given to the Mughal emperors. Hamida Begim, Humayun's Persian wife and the mother of Akbar, received the title Maryam Makani (In the Place of Mary), while Akbar's Rajput wife and the mother of Jahangir, Jodha Bai, was entitled Maryam-i Zamani (The Mary of Her Time). Jahangir's Rajput wife, the mother of Shah Jahan, received the title Bilqis Makani (In the Place of Bilqis, i.e., the Queen of Sheba). Jahangir's Persian wife Mihr al-Nisa first received the title Nur Mahal (Light of the Palace) and later Nur Jahan (Light

\footnotetext{
372 Kozlowski, Gregory C., "Private Lives and Public Piety: Women and the Practice of Islam in Mughal India," Women in the Islamic World, ed. by Gavin Hambly, NY: St. Martin's Press, 1998, p. 483.

${ }^{373}$ Inayat Khan, Shah Jahan Nama, p. 572.
} 
of the World). Her niece, Arjumand Begim, was the famous Mumtaz Mahal (Pearl of the Palace) for whom her husband Shah Jahan built the Taj Mahal. Other titles given her include Malika-i Jahan (Queen of the World) and Mahd-i 'Ulya (Most Elevated Cradle). Her daughter Jahanara (Jewel of the World) was given the official title Sahibat-i Zamani (Mistress of Her Time), although like Babur's sister Khanzada Begim and, later, Aurangzeb's daughter Zinat al-Nisa, was generally known as Begim Sahib (Great Lady). The general public was aware of the individual personalities of the women of the Mughal royal house and, just as diplomats from the Chinese court had brought specific gifts for the individual wives of Timur in Samarqand, European merchants and missionaries knew well to bring presents to individual women of the Mughal ruling house. Nur Jahan was said to have delighted in a European horse carriage, which had been brought to the Mughal court as a gift for her by Sir Thomas Roe, the seventeenth-century English ambassador to the Mughal court. ${ }^{374}$

Women continued to regularly intervene in Mughal dynastic politics. When Akbar's son, Salim, the future Emperor Jahangir, threw himself recklessly into rebellion in 1601, his mother Miryam Makani and the elderly, widowed Gulbadan Begim successfully intervened with Akbar, preventing him from imposing retribution on his son. When Jahangir's son, Khusraw, rebelled against his father in 1606, the entire harem seems to have become involved. The emperor considered a court favorite, Mirza Aziz Koka, to have been the instigator of his son's mutiny. Koka's execution seemed imminent, yet the sources describe the intervention of a veritable committee of Mughal

$\overline{{ }^{374} \text { Schimmel, Great Mughals, p. } 163 .}$ 
women, with Salima Sultan calling out from behind a screen to the emperor, "Your majesty, all of the Begims are assembled in the zenana for the purpose of interceding for Mirza Aziz Koka. It would be better if you come there, otherwise they will come to you." Jahangir was thus constrained to go to the women's apartments and, under their pressure, pardon the miscreant. ${ }^{375}$

Power, Patronage and Youth

Even youth created no barrier to power; young Mughal women played critical roles at the Indian court. Significantly, at a time when the last of the influential elderly female Timurid relations in the Mughal household had passed away, their place was taken over by the young wives, daughters and sisters of the emperor, who began to play increasingly powerful roles in imperial politics. As defenders of the imperial dynasty, their right to involve themselves politically was acknowledged and accepted, and women of the Mughal court continued to regularly intervene. On the death of his beloved wife Mumtaz Mahal in 1631, only three years after his accession to the throne, Shah Jahan relied heavily on his eighteen-year-old unmarried daughter, Jahanara, to manage the imperial household. Jahanara arranged marriages for her brothers Dara Shikuh, Aurangzeb and Shuja, organizing the court festivities and collecting the presents. The degree of her influence at court was so great as to lead suspicious foreign observers to salaciously suggest an incestuous relationship between the emperor and his daughter, for

\footnotetext{
375 As quoted in Misra, Women in Mughal India, p. 33. Some may consider Mirza Aziz Koka deserving of punishment, as he is quoted as having once said, "Every man should have four wives: a Persian with whom he can converse, a woman from Khurasan to do the housework, a Hindu woman to raise the children and one from Transoxiana, whom he can beat as a warning to the others." In Schimmel (quotation unattributed), Great Mughals, p. 155.
} 
how else could a young, unmarried woman wield such enormous authority at court? ${ }^{376}$ The French jewel merchant Jean-Baptiste Tavernier described her enormous personal wealth as a result of "improper relations with Shah Jahan.",377

Jahanara, who was called by her father Sabihat al-Zaman (the Mistress of her Age) or Padshah Begim (Lady King), and more generally as Begim Sahib (Great Lady) controlled vast personal financial resources, part of which she had accumulated through her trade relationship with Dutch merchants, but most of which, totaling cash and goods valued at over ten million rupees, had been left to her by her mother, Mumtaz Mahal. ${ }^{378}$ Jahanara used her wealth to change the landscape of her father's new capital city outside of Delhi, where between 1648 and 1650 the emperor's eldest daughter built a mansion, a marketplace (the Chandni Chowk) the largest garden in the city (the Sahiba Abad Bagh), a caravanserai and Shahjahanabad's largest bathhouse. Her mansion, built in the family area of the palace, overlooked the Jamuna River, its walls and ceilings decorated as a shish mahal, with bits of glass and mirror embedded in the plaster to catch reflections from the strategically placed candles. ${ }^{379}$ Her central marketplace, the Chandni Chowk, contained 1, 560 shops, and the Paradise Canal ran down the middle, watering rows of shade trees. ${ }^{380}$ To the west of the Chandni Chowk, Jahanara built a caravanserai that was

\footnotetext{
${ }^{376}$ Francois Bernier, Travels in The Mogul Empire, AD 1656- 1668, Archibald Constable, ed. and tr., $2^{\text {nd }}$ ed., Delhi: Low Price Publications, 2005, p. 12.

${ }^{377}$ Jean- Baptiste Tavernier, Travels in India, tr. and ed. by V. Ball, $2^{\text {nd }}$ ed., Delhi: Low Price Publications, 2000, I, p. 275.

${ }^{378}$ Kozlowski, "Private Lives," p. 476.

${ }^{379}$ This was a common practice in the eighteenth century palaces of the Rajputs, a glorious example being the Shish Mahal of Amber Fort, outside of Jaipur.

${ }^{380}$ Stephen Blake, "Contributors to the Urban Landscape: Women Builders in Safavid Isfahan and Mughal Shahjahanabad," in Women in the Medieval Islamic World, Gavin Hambly, ed., New York: St. Matin's Press, 2002, p. 420. A second branch of the canal watered Jahanara's Sahiba Abad garden. Blake describes the activity at the Chandni Chowk, with merchants and traders from Anatolia, Zanzibar, Syria, Yemen, Arabia, Khurasan, China, Tibet, England and Holland, selling rubies from Badakhshan, pearls from Oman, fruit from Kashmir and Central Asia, weapons, fine cloth, perfumes, elephants, horses, camels,
} 
considered "the most imposing structure in the city after the Jami Masjid." 381 Unlike the usually more anonymous woman builders of the Ottoman and Safavid courts, known to have commissioned numerous imperial mosques and madrasas, Jahanara's intention was not solely the glorification of the dynasty but personal recognition. ${ }^{382}$ "I will build a serai, large and fine like no other in Hindustan. The wanderer who enters its courts will be restored in body and soul and my name will never be forgotten." 383

In the most dramatic Mughal succession war, in a dynasty which indulged in regular bloody sibling conflict, the powerful sisters of rival brothers Dara Shikuh and Aurangzeb, Jahanara and Raushanara (who herself had built a garden and tomb garden in Shahjahanabad) contributed their public partisanship: each passed messages, agitated at court for her favorite, led a faction, and went into exile or achieved power at the resolution of the conflict. When Dara Shikuh was defeated and killed, his supporter, Jahanara, joined their father, Shah Jahan, in prison in Agra fort, in a white marble palace upriver from the Taj Mahal. On the death of Shah Jahan in 1666, Jahanara returned to Shahjahanabad and was lodged by the respectful Aurangzeb in one of the finest mansions in the city, during which time she composed her famed biography of the Sufi shaykh Mu'in al-Din Chishti.

birds, water pipes, sweets, tapestries and broadcloth. There were plentiful coffee and wine shops, and child dancers and storytellers performed on the street. The Chandni Chowk remains an active, vital, and overwhelmingly crowded, market neighborhood in contemporary Delhi, across a wide highway from the gates of the Red Fort of Shah Jahan, now a museum

${ }^{381}$ Francois Bernier, Travels in the Mogul Empire, AD 1656- 1668, "Letter to Monsieur de la Mothe le Vayer," Archibald Constable, trans and ed., $1^{\text {st }}$ pub. 1934, Delhi: Low Price Publications, 2005, pp. 230299. See also Blake, "Urban Landscape," p. 421.

382 This is certainly not to diminish the role played by imperial Ottoman and Safavid women, who changed the landscapes of Istanbul and Isfahan through their beneficent patronage of monumental religious monuments such as the still dramatic Valide Mosque in Istanbul.

${ }^{383}$ Blake, "Urban Landscape," p. 421. 
The power of Mughal women was of course not only political and dynastic; it can additionally be located in their role as patrons of and participants in the arts. Mughal women were well educated; scholarly female tutors referred to as Atun Mama were employed to teach not only comportment but also Persian, Arabic, theology, and history, as well as classic literature, primarily the medieval Persian poets. ${ }^{384}$ The indomitable Gulbadan Begim, who was known to possess a large and valuable library, composed her memoir, the Humayunnama, at the urging of her nephew, Akbar. The famous patron of urban architecture, Jahanara, was a recognized scholar who, at the instigation of her brother Dara Shikuh, was indoctrinated into the Qadiriyyah order of Sufis and composed the Risalah-i Sahibiya as an exploration of her Sufi leanings, as well as the previously mentioned biography of the Sufi Sheikh Muinuddin Chishti, the Mu'nis al-Arwah (1640) and a brief biography of the Sufi Mulla Shah, the Sahibiyah, with a dozen verses of her own poetry included in the volume. ${ }^{385}$ She wrote of a having a vision in 1671 , in which the Prophet and the first four caliphs (Abu Bakr, Umar, Uthman, and Ali) sat together with her sponsor in the Qadiri order, to whom the Prophet asked, "Oh, Mullah Shah, for what reason have you enlightened this Timurid girl?"386 Under her beneficent patronage a series of works on Sufism was produced which included commentaries on Rumi's

\footnotetext{
${ }^{384}$ As already described, one of these tutors is on Gulbadan Begim's list of women attending the wedding feast for Babur's son Hindal in 1537 in Agra. According to Beveridge, this particular Atun Mama, referred to only by her title, belonged to the retinue of Babur's mother, Qutluq Nigar Khanim. Although she had been left behind in Samarqand at the time of the Uzbek conquest because there was no horse for her to ride to safety, she came on foot to Pishgar, northeast of Samarqand, to rejoin Babur in 1501 and seems to have remained with him thereafter. He reports giving Atun a village near Kabul in gratitude for her loyalty. Humayunnama, BA, p. 208. Baburnama, f. 241, see Dale, Garden, p.120.

${ }^{385}$ D.N. Marshall, Mughals in India: A Bibliographical Survey, New York: Asia Publishing House, 1967, p. $218-9$.

${ }^{386}$ Schimmel, Great Mughals, p. 151.
} 
Masnawi. ${ }^{387}$ A court poet of seventeenth- century Shahjahanabad, Mir Muhammad Ali Mahir, composed his own masnavi in praise of Jahanara's patronage and generosity. ${ }^{388}$ She was buried, at her own request, having prepared her own epitaph, in an unmarked white marble sepulcher in the Delhi courtyard of the shrine of the famed Chishti Sufi sheikh, Nizam al-Din Auliya, who had some years before been referred to by her brother, Dara Shikuh, as "the patron saint of the House of Akbar." 389

Aurangzeb's eldest daughter, Zib al-Nisa Begim, was so accomplished a scholar that her father sent for the famous Persian poet Mulla Said Ashraf Mazandarani to mentor and tutor her, and rewarded her with thirty thousand gold pieces for committing the entire Quran to memory. She studied astronomy and mathematics, was a renowned calligrapher, arranged for the translation of many religious classics and patronized many scholars and poets at her court. Poems ascribed to her include the lovely verse, "Were an artist to choose me for a model/ How could he draw the form of a sigh?" ${ }^{390}$ Zib al-Nisa Begim and Mazandarani remained loyal correspondents for the rest of her life.

Perhaps the most famous of Mughal imperial women was Nur Jahan, who married the fourth Mughal emperor, Jahangir, as a thirty-six-year-old Persian widow with a young daughter. They had no children together, but Jahangir never married again and preferred the companionship of Nur Jahan to all others at the court. She displayed exceptional political and administrative acumen, quickly earning the admiration and trust of her husband. Jahangir went so far as to grant her the right of sovereignty: "Sometimes she would sit in the balcony of her palace, while the nobles would present themselves and

\footnotetext{
${ }^{387}$ Ibid., p. 153.

${ }^{388}$ Stephen P. Blake, "Urban Landscape," p. 416.

${ }^{389}$ Marshall, Bibliography, p. 218.
} 
listen to her dictates. ${ }^{״ 391}$ Drums were beaten at her advance, royal fermans were signed with her seal and coins were struck bearing the inscription, "By order of the King Jahangir, gold has a hundred splendors added to it by receiving the impression of the name of Nur Jahan, the Queen Begim." ${ }^{„ 392}$ The emperor was accused by some of having abdicated imperial authority to his wife, although other contemporary accounts make no such claim and his memoirs suggest that that Jahangir remained deeply involved in the political affairs of his realm until the last five years of his reign, when a lifetime of drinking and drug use made him an invalid. Nur Jahan served as co- regent to a king who perhaps did not so much neglect authority as delegate it to a trusted and talented partner.

Nur Jahan wrote poetry and composed songs, although so many Mughal women composed verse under the same name, Makhfi (hidden), that it is difficult to identify specific authors. ${ }^{393}$ Among myriad other attributes, the queen was a skilled shot and regularly accompanied her husband on his favorite pastime, the hunt. ${ }^{394}$ On one occasion she shot four tigers with six shots. Her delighted husband wrote, "Until now such marksmanship has not been seen-- from atop an elephant and from inside a howdah.... As a reward for such marksmanship I scattered a thousand ashrafis over her head and gave her a pair of pearls and a diamond worth a lac of rupees." ${ }^{395}$ When, in the last years

\footnotetext{
${ }^{390}$ Schimmel, Mughals., p. 154.

${ }^{391}$ Mu’tamid Khan, Iqbalnama-i Jahangiri, E\&D, VI, p.405.

${ }^{392}$ Ibid.

${ }^{393}$ Authors using the nom de plume (takhallus) of Makhfi included not only Nur Jahan, but also Zib alNisa, Aurangzeb's accomplished daughter, and Salima Sultan Begim Chaganiani, a grand- daughter of Babur, who arrived in India with Gulbadan Begim and her mother in the first wave of Timurid immigration and accompanied Gulbadan Begim on the hajj in $983 \mathrm{H}$.

${ }^{394}$ For example, Nur Jahan was responsible for innovations in clothing design, and is rumored to have been a painter of miniatures, as well as a poet and skilled imperial administrator. Her mother is said to have invented attar of roses.

${ }^{395}$ Jahangirnama, p. 214. Thackston, tr., p. 219.
} 
of his reign, Jahangir was captured by a rebellious nobleman, it was Nur Jahan, of all his court, who organized and executed his eventual rescue. ${ }^{396}$

\section{Timurid-Mughal Motherhood}

At the height of their imperial grandeur in India the Mughal family remained notably loyal to the dynastic systems of their ancestors and continued to offer imperial recognition of an individual woman's genealogical pedigree. As Timurid custom had allowed even young and/or childless noblewomen to develop influence and resources, so too Mughal women of the later period remained similarly free of limitations on female access to power. In contrast, their Ottoman contemporaries developed a unique set of imperial controls over dynastic marriage, sexuality and motherhood. The dramatic differences which developed between these two Turkic dynasties are striking and instructive-- while the Mughals retained traditional Timurid systems, at the Ottoman court female access to power became entirely removed from a woman's personal lineage, being instead inextricably linked to the birth of a male heir and the onset of postreproductive years.

The earliest Turkic writings from Central Asia confirm the importance of both parental genealogical lines in the establishment of royal lineage, but by the fourteenthcentury the Ottoman court had become so cautious in managing the integrity and autonomy of the dynasty that a system of near- anonymous maternal concubinage had replaced wives as "bearers of the dynasty's progeny.",397 While strategic political marriages to women of noble birth continued to take place, after Osman and Orhan

\footnotetext{
${ }^{396}$ A full description of Nur Jahan's rescue of the Emperor Jahangir is given in Mu'tamad Khan, Iqbalnama, E\&D, VI, p. 430.
} 
virtually all Ottoman princes were born of concubine mothers. Already devoted to a policy of slave soldiers and administrators, the Ottoman system of slave mothers, to the absolute exclusion of reproduction through legal marriage, may have been driven by similar hopes of undiluted dynastic loyalty. Certainly the Ottoman policy was successful in that it prevented the development of divisive political roles among maternal relatives, as the princes' maternal identity and lineage were generally unacknowledged at the Ottoman court. ${ }^{398}$

Having entered the royal harem without lineage or pedigree, Ottoman mothers developed a retroactive status as the mothers of sons and as protectors of princely power. Still, real political maturity continued to be withheld from Ottoman women until the complete cessation of childbearing. It was not menopause which ended a woman's reproductive status but the birth of a son, whose training and protection then became her sole charge and responsibility. The Ottoman policy of one mother/one son guaranteed each prince a vital political alliance with the one person at court whose loyalties were personal and undiluted: his mother. As the custodians of imperial continuity, the mothers of royal sons could at times acquire great influence and power. Their power was dramatically limited by public perception—support for a woman's public display of influence could disappear rapidly if her actions seemed to be motivated by the selfish desire for acquisition of personal power rather than simply for the support and protection of her son. Ottoman imperial manipulation of female political maturity extended to the princesses of the royal house, who were prevented from displaying public power and

\footnotetext{
${ }^{397}$ Leslie Peirce, Imperial Harem, pp. 16 and 23.
} 
wealth until their own post- sexual years; it has been suggested that major public works were established only by widowed princesses. ${ }^{399}$ Women of the Ottoman court were allowed access to power only through the suppression of a reproductive role and/or the birth of a son. "Women without sons were women without households and therefore women of no status. ${ }^{400}$

In contrast, childless Timurid women were able to dramatically influence dynastic politics. The most powerful women of the Timurid period were often childless, and Beatrice Manz has suggested that "producing a son did not markedly enhance the position of a low status woman. ${ }^{, 401}$ Neither of Timur's Chingizid wives, Saray Mulk Khanim or Tokel Khanim, had surviving children and yet their power and influence were well noted by foreign visitors to the court. ${ }^{402}$ "Maternity was not in itself a path to power;" it was a woman's personal qualities and pedigree that allowed her to develop a prestigious dynastic position. ${ }^{403}$

Even the Timurid-Mughal practice of inter-familial adoption does not seem to have had any impact on the adoptive mother's already substantial power and influence. The Timurid system of fosterage has never been fully explained or explored, but it seems to have been a common custom for elite women, most often the wives of the ruler and high-ranking amirs, to take into their households the children of sisters, daughters and

\footnotetext{
${ }^{398}$ This did not of course prevent the development of powerful political factions around the princes and their mothers, but merely removed maternal relations as possible players in the regular succession wars and power struggles which rocked the Ottoman palace.

${ }^{399}$ Peirce, Imperial Harem, p. 23.

${ }^{400}$ Ibid. As Jane Hathaway comments, this of course implies that the household was the key ingredient to imperial power, hence my assertion that the early modern dynastic families were unable to separate the political from the private.

${ }^{401}$ Manz, "Dynastic Politics," p.12.

${ }^{402}$ Clavijo, Embassy, 310.

${ }^{403}$ Manz, "Dynastic Politics," p. 12.
} 
common wives. ${ }^{404}$ For example, arrangements were made before his birth to have Timur's grandson Ibrahim ibn Shahrukh raised by one of Timur's wives, Tumen Agha, rather than by his natural mother; many of Timur's grandchildren were raised "among Timur's wives." ${ }^{405}$ Timur's daughter-in-law, Gawarshad, wife of Shahrukh, raised her grandchildren: Ulugh Beg's son Abd al-Latif, his daughter Hasiba Sultan Khanzada and Baysunghur's son Ala al-Dawla. ${ }^{406}$ It has been pointed out that this practice brought grandchildren into the central imperial household, where they were raised and educated together under the close watch of the ruler. ${ }^{407}$

According to the sources, Sultan Husayn Bayqara's wife Afaq, daughter of Abu Sa id, had no children but "reared and educated nine children of [Sultan Husayn Bayqara] by her own foster-sister, Baba Agacha.. ${ }^{408}$ Habiba Sultan Khanish Dughlat, a Chaghatay cousin of Babur, married her cousin Sa id and raised one of his children, Rashid, whose mother was a "tribeswoman." "409 Babur's maternal grandmother, Isan Dawlat Khanim, raised three of her own daughters and fostered a half-sister of Babur, Yadgar, "Souvenir," who had been born after the death of her father. ${ }^{410}$ Babur's daughter, Gulbadan Begim, herself was taken at age two from her mother, Babur's wife Dildar Begim, to be raised by another of Babur's wives, Maham Begim. Gulbadan's full brother, Hindal, was taken into Maham Begim's household only three days after his birth. The arrangements for the

\footnotetext{
${ }^{404}$ Manz, "Dynastic Politics," p. 11.

${ }^{405}$ Ibid.

${ }^{406}$ Ibid.

${ }^{407}$ Ibid

${ }^{408}$ Humayunnama, BA p. 203.

${ }^{409}$ Ibid., pp. 235-6. Habiba Sultan Khanish Dughlat led a life of adventure deserving of comment: taken captive by the Uzbeks as a child, she was raised in the household of Shibani Khan and eventually married to his nephew, Ubaydullah, whom she left c. 1511 when the Uzbeks retreated to Turkestan. She remained in Samarqand, joined her Dughlat uncle, married her cousin, was widowed in 1533 and was present in India for the Timurid celebration of the Mystic Feast in 1531 and the wedding of Babur's son Hindal in 1537.
} 
adoption had been made long in advance and were reconfirmed by the adoptive mother in a letter to Babur, then campaigning in Swat. Maham wrote to request that Babur perform "the divination" to determine the sex of Dildar's as yet unborn child, although she confirmed that it didn't matter were it boy or girl; she would take the baby either way. ${ }^{411}$ Still, Maham's fosterage of the children was most assuredly not an indictment of Dildar's parenting; she gave birth to three more of Babur's children and regained parenting rights to a still young Gulbadan when Maham died. Perhaps Babur's willingness to allow Maham to foster the children of her co- wife was driven by sympathy, as all of her children had died as babies but for one, the future emperor Humayun. In any case, the custom of fostering was well- established and commonly applied. Among the later Mughals the custom of foster parentage seems to have gradually fallen out of favor, perhaps due to the increasingly linear succession patterns assumed by the dynasty in India. All the same, Jahangir's memoir mentions that his half sister, Shahzada Khanim, daughter of a serving girl, was given by her father, Akbar, to be raised by Maryam Makani. ${ }^{412}$ Hindal's daughter, Ruqayya Begim, Akbar's first wife, who had no children of her own, raised Jahangir's son, the future emperor Shah Jahan.

It has been suggested that shared parentage/fosterage was the Timurid strategy for avoiding extreme cases of advocacy by mothers on the part of their royal sons, advocacy which could be destructive to the dynasty, as can be seen in seventeenth-century Ottoman history. ${ }^{413}$ This may explain the origins of the custom but does not address the fosterage of so many female royal children and, of course, ignores the possibility of passionate

\footnotetext{
${ }^{410}$ Ibid., p. 244-5.

${ }^{411}$ Humayunnama, p. 9.

${ }^{412}$ Jahangirnama, p. 20.
} 
advocacy on the part of a foster mother. Nor was the custom of fosterage devoted to removing children from less well- born or incompetent mothers; none of the sources records complaints against the mothers whose children were fostered elsewhere. For example, the lineages of both Maham Begim, Gulbadan's adoptive mother, and Dildar Begim, Gulbadan's biological mother, are obscure; as the lineage of royal-born wives was carefully recorded this seems to indicate that both women were of non- royal descent. Most interestingly, while women without influence do not seem to have been able to adopt the children of others, those women who had influence did not enhance it by adopting children from within the dynasty. Neither marriage nor maternity, nor even the assumption of parenting responsibilities, seems to have played a critical role in establishing degrees of participation or power among women of the Mughal court.

\section{Marriage and the Mughal Princess}

Foreign observers, struck by the power and independence of such young and unmarried Mughal women, explained it away with the suggestion that by the reign of Shah Jahan, the Mughal despots were no longer allowing their daughters to marry. Francois Bernier, a French doctor who remained at the Mughal court from 1658 until 1667, justified Jahanara's support of Dara Shikuh's claims to the throne by claiming she had been coerced, bribed by her brother's promise that, as the next emperor, he would permit her to marry. "This pledge was a remarkable one, the marriage of a Princess being of rare occurrence in Hindoustan, no man being considered worthy of royal alliance." 414

\footnotetext{
413 Manz "Dynastic Politics," p. 11.

${ }^{414}$ Bernier, Travels, p.12. Italics are original.
} 
It is true that many of the most influential women of this period were royal sisters and daughters, who remained permanently unmarried. ${ }^{415}$ It has been suggested that perhaps unmarried imperial daughters offered the emperors, "a way of enhancing [their] magnificence and power, underlining [their] remoteness and inaccessibility," perhaps a factor for the increasingly rigid and distant emperor Shah Jahan, although his Mughal predecessors do not seem to have valued imperial distance. ${ }^{416}$ It is also true that the number of viable male Mughal marriage partners was limited, particularly after Shah Jahan's act of accessional fratricide, ${ }^{417}$ but Mughal princesses had long intermarried with the Safavid and Uzbek nobility and with members of the religious elite, such as those of the Ahrari Naqshbandi order of Sufis, so it cannot have been a mere shortage of viable husbands that convinced so many Mughal women to remain unmarried. Rather, it is reasonable to presume that because access to real power was readily available to elite women at the court regardless of age or marital status, these well-educated and influential women made the decision to reject marital alliances, which may have threatened their well-developed pre-existing interests and loyalties. Perhaps, with access to power not driven by marriage, age or motherhood, powerful Mughal women remained unwed by choice.

\footnotetext{
${ }^{415}$ For example, Akbar's sisters and daughter, Jahangir's daughter, Dara Shikuh's daughter and Aurangzeb's daughters.

${ }^{416}$ Blake, "Urban Landscape," p. 415.

${ }^{417}$ Shah Jahan was the first Mughal emperor to slaughter male members of the ruling family-- brothers, cousins and nephews-- immediately upon his accession to the throne, in an effort to prevent the later emergence of viable contenders for imperial power. See chapter five, Princes and the Mughal Succession, for a detailed explanation.
} 


\section{The Non- Timurid Wives of Timurid Rulers}

Women of power and influence, unique individuals, artists and poets in the public view, wealthy patrons, builders, hunters, polo players, musicians, calligraphers and craftswomen can be located in every generation of Timurid- Mughal imperial power, although many of these Mughal wives were themselves not Central Asian Timurids. Babur himself was, as we have seen, half Timurid Turk (on his father's side) and half Chaghatay Mongol (on the side of his mother), and such intermarriage was common in Timurid Mawarannahr. While Babur often referred to himself as a Turk, ethnic identity was clearly not an important factor in the careful construction of Timurid or, later, Mughal imperial identity; it was comfortably replaced by the Mughals' consistent identification of themselves dynastically as descendants of the House of Timur (note Jahanara's mystical vision of the Prophet, who referred to her as "that Timurid girl").

Babur and Humayun had married Persian and Afghan women as well as Turks and Mongols; Akbar and his descendants made many notable political marital alliances with the Rajput royal families, all of which resulted in such a dilution of the royal bloodlines that by the time of the famously conservative Sunni emperor Aurangzeb, the Mughal kings had become much more (Shi'i) Persian and (Hindu) Rajput in ancestry than Turkish or Mongol! ${ }^{418}$ In fact, two of the most renowned of Mughal dynastic women Nurjahan, wife and queen of Jahangir, and her niece, Mumtaz Mahal, for whom Shah Jahan built the Taj Mahal, were descendants of Persian immigrants to India. And although the assumption is that their cultural heritage must have had a subtle influence

\footnotetext{
${ }^{418}$ Babur's grandson Akbar was half (Khurasani) Persian and half Timurid (that is, Turco- Mongol), Jahangir was half Rajput, one quarter Persian and one quarter Timurid; Shah Jahan was three quarters
} 
within the family, there is no indication that Rajput wives and mothers had a dramatic impact on the public political activities of the Mughal dynasts. ${ }^{419}$ Instead, when women entered the Timurid family, their interests seem to have merged with the dynasty with which they had become allied through marriage, as their imperial titles reflect, universally employing a "common, international, Perso-Islamicate political discourse."420

Their concern for the success of the imperial project, and their willingness to participate in its survival and expansion, was recognized and made ample use of by male members of the imperial family. Timurid and Mughal men, from Timur to Babur and beyond, had always relied on the support and assistance of Timurid- Mughal women, not even primarily as sexual partners or as the producers of dynastic progeny, but as social companions and political partners. Having as much at stake as their brothers, fathers, husbands and sons, Mughal women were engaged participants in and public supporters of the imperial project.

\section{Timurid-Mughal Continuity}

To produce a list of individuals and their accomplishments adds little to the general debate over the relative independence of Mughal women and their public expressions of identity. Ahistorical journalistic accounts of anecdotal evidence demonstrate only the presence of individual women of note, removed from the context of society or culture. In order to discover something of real value we must look at the broader trends which confirm or deny a woman's consistent access over time to a public

Rajput, one-eighth Persian and one-eighth Timurid; and Aurangzeb's mother was Persian, leaving him only one-sixteenth Timurid!

419 There is a lovely pair of Jahangiri miniatures which show the emperor Jahangir participating in Hindu religious celebrations among the women of the Mughal household. 
space, political influence, personal economic power, individualism and self-expression. An examination of multiple generations of elite Timurid- Mughal women confirms a remarkable degree of cultural continuity, reaching from the royal tent encampments of Tamerlane to the peripatetic courts of Babur and Humayun, to the magnificent Indian courts of Akbar, Jahangir, Shah Jahan and Aurangzeb.

It is clear that the boundaries of the post- Akbar Mughal harem were porous and did not entirely restrain or hamper the public activities of elite Mughal women. The entire royal court did not, as has been suggested, calcify and sedentarize due to Akbar's innovations but in fact continued to retain a peripatetic Timurid character. ${ }^{421}$ Although the unstable and desperate days of Babur and Humayun were over, Akbar's new city of Fatehpur Sikri remained the imperial capital for a mere fourteen years, after which the royal court moved to Lahore before eventually returning to Agra. Jahangir, arguably the most peripatetic of Mughals, spent fully half of his reign away from Agra, traveling slowly across the empire, spending time in Kashmir and Kabul, among other favorite Mughal centers. In the latter half of his reign, Shah Jahan built an entirely new imperial capital near Delhi, but his son Aurangzeb moved the entire administrative and military headquarters of the Mughal empire to a tent city in the Deccan for more than twenty-six years.

In fact, none of the Mughal kings maintained a permanent capital that served his imperial project in the manner that Istanbul, for example, came to symbolize Ottoman

\footnotetext{
${ }^{420}$ Kozlowski, "Private Lives," p. 475.

${ }^{421}$ See Lal, "Historicizing the Harem," previously cited.
} 
imperial sovereignty for almost six hundred years. ${ }^{422}$ While a physical space was occasionally articulated and constructed within which to separate a domestic world, in reality women of the still peripatetic Mughal elite continued to regularly cross out of that space and into the public forum. In the classic pattern of Timurid rule, the women of India's Mughal court governed provinces, traveled extensively, built private palaces, participated in trade and diplomatic negotiations, joined in feasts and hunting parties, and in many ways operated as full partners in the affairs of the dynasty. While not always prominent in the chronicles of the period, women of the imperial family regularly make appearances in significant roles "close to the ranks of their more prominent masculine contemporaries. ${ }^{, 23}$ The comfortable cultural accommodation of independent elite women was a component of the Timurid cultural and social legacy which was inherited and carefully maintained by the Mughal dynasty of India.

\footnotetext{
${ }^{422}$ The Ottoman court's move to Edirne in the seventeenth century, an effort to avoid the overwhelming political/ religious factionalism in the capital, was temporary, and although Edirne remained an important imperial city, to this day Istanbul represents the grandeur and might of the Ottoman past.

${ }^{423}$ Kozlowski, "Private Lives,” p. 470.
} 


\section{CHAPTER 5}

\section{MUGHAL PRINCES \\ AND THE IMPERIAL SUCCESSION}

The scholarly and artistic output of generations of Timurid- Mughal princesses demonstrates the value placed on the education of women at the court, yet the education and training of Timurid- Mughal sons, as potential rulers, was even more comprehensive. Timurid princes of Mawarannahr had been given an increasingly urban and sophisticated education which drew heavily from the Persian and Arabic literary and historical classics. The highest expression of this education was their participation in and patronage of the arts, reflected in their role as "the leading arbiters of literary taste through the eastern Islamic world., 424

Unfortunately, there is little information in the sources regarding the formal education of royal sons. Babur's schooling receives no mention in his own memoir, although his erudition is evident, but his nephew, the author of the Tarikh-i Rashidi, Mirza Haydar Dughlat, offers a detailed description of his training as a prince of the Chaghatay Mongols, living with his father in Timurid Khurasan:

As it is customary to send children to school when they are four years, four months, and four days old, my father wanted to send me to school. For a felicitous and blessed commencement, he took me first to the Shaykh al-Islam [Mawlana Sayfuddin Ahmad] and begged him to instruct me. The sheikh wrote

${ }^{424}$ Lentz and Lowry, p. 113 
the words rabbi yassir (My Lord, make it easy), took me tenderly on his knee and gave me instruction with the utmost amiability and compassion., ${ }^{, 425}$

Mirza Haydar's studies continued under the supervision of various Khurasani shaykhs until he was orphaned at the age of thirteen and entered the service of his cousin, the Mongol Sultan Sa id Khan. During his twenty-four years of service to the khan, Mirza Haydar continued his education, which he claims included expertise in calligraphy and writing, poetry and its technique, chancery composition, painting and illumination, and mastery of "arts and crafts like seal engraving, carving, and goldsmithery; making saddles, armor, arrows, and knives; gilding, building, carpentry.... administrative affairs and running the kingdom, like holding council, doing battle with outlaws, nighttime travel, archery, hunting, falconry, and things useful in affairs of state...."426 The author's inclusion of archery, falconry and hunting among the "affairs of state" reflects an attitude that was commonly shared by the Timurid- Mughals, for whom the skills required for blood sport only enhanced a prince's military and political strengths. In thanks for this well-rounded education, Mirza Haydar dedicated his "poor effort," the Tarikh-i Rashidi, a history of the khans of Mughulistan, to his protector and teacher, Sultan Sa id Khan, writing, "A king sent his son to school. When he set down his silvery tablet, on it was written in gold: A teacher's severity is better than a father's love." ${ }^{427}$

As in Timurid Transoxiana, only small glimpses into the education of the Mughal princes of India are given us. As one might expect, Babur, himself an erudite poet,

\footnotetext{
${ }^{425}$ Mirza Haydar Dughlat, Tarikh, p. 124. This verse of the Quran (20:26) traditionally began a child's education. According to Mirza Haydar, Mawlana Sayfuddin Ahmad was the grandson of Mawlana Sa duddin Taftazani, who had been Shaykh al- Islam in the time of Timur.

${ }_{426}$ Ibid., pp. 4-5.

${ }^{427}$ Ibid., p. 236.
} 
scholar and memoirist, took a personal interest in his son's education, complaining of Humayun's inattention to penmanship in a chiding letter written just a few years before his death, while Humayun was serving as governor of Badakhshan. "Although your writing can be read with difficulty, it is excessively obscure," Babur complained. "Who has ever heard of prose designed to be an enigma (mu'amma)?,428

According to Abu'l Fazl, Babur's grandson, Akbar, was assigned a tutor at the age of four years, four months and four days, the traditional age to commence the education of a Central Asian Timurid prince, even while he was a captive at the court of his seditious uncle Kamran. ${ }^{429}$ In the spirit of the wide-ranging liberal education offered to Timurid princes, Akbar was trained as a painter in his youth. ${ }^{430}$ Abu'l Fazl briefly mentions the education of Akbar's son Salim, the future emperor Jahangir, also commencing at exactly four years, four months and four days. "There was a great feast and the holy spirit of that pupil of the eye of sovereignty [Salim]... began outward instruction... [and] was increased in brilliancy by the oil of instruction....After that he began with the letters of the alphabet (huruf-i abjad), which are the foundation of learning and the center of things visible, and so was guided to the highness of wisdom."

At least in theory, education was not only for princes but for all boys of the Mughal Empire. Schools were opened in the capitals, and Abu'1 Fazl wrote that "every

\footnotetext{
${ }^{428}$ Baburnama, Mano, p. 559. Thackston, tr., p. 742. The enigma, or mu 'amma, was a literary convention popular in the Persian-speaking Timurid world, even "a particularly fashionable Harati exercise," in which the listener/ reader was required to undo several layers of meaning in what was, in essence, a poetical riddle. See Abolala Soudavar, "The Early Safavids and Their Cultural Interactions with Surrounding States," Iran and the Surrounding World, Nickie Keddie and Rudi Matthee, eds., Seattle and London: University of Washington Press, 2002, pp. 89- 120, p. 93.

${ }^{429}$ Abu'l Fazl, AN, I, pp. 518- 19.

${ }^{430}$ Dye, "Imperial Mughal Painting," p. 147.
} 
boy ought to read books on morals, arithmetic, the notation particular to arithmetic, agriculture, mensuration, geometry, astronomy, physiognomy, household matters, the rules of government, medicine, logic, tabi'i (natural or physical sciences), riyazi (quantitative sciences, such as math, music, astronomy and mechanics) and illahi (theological sciences) and all history." ${ }^{432}$

Like princesses of the royal house, Mughal princes were artists, poets, diarists and authors. Humayun's brother, Kamran Mirza, composed a Divan of Turkish and Persian lyrical poems in addition to the Mirzanama, relating "the rules of good conduct" in verse and prose. ${ }^{433}$ Shah Jahan's eldest son, Dara Shikuh, was a renowned scholar and member of the Qadiri Sufi order. He most famously composed a treatise, The Mingling of Two Oceans (Majmu' al-Bahrain), which compared and conflated Islamic and Hindu devotional traditions. ${ }^{434}$ Under the pen name "Hanafi Qadiri" he composed a short collection of biographies of Sufi shaykhs, from the origins of Islam to his own period, the Safinat al-Auliya (c.1640); a biography of the seventeenth-century Indian mystic of Lahore, Mir Muhammad (Miyan Mir or Miyan Jiv), the Sakinat al-Auliya (c. 1642-3); a few Sufi tracts, including the Risalah-i Haqq Nama (c.1645) and Tariqat-i Haqiqat (also called the Rasa'il-i Tasawuf) in mixed poetry and prose; an annotated collection of sayings by various mystics, the Hasanat al-Arifin (c. 1652, and also known as the Shatahat, Shathiyat-i Dara Shikuh, or Risalah-i Shathiyat); another volume of poetical quotations, the Bayaz al-Shu'ara; as well as a few small volumes of verse and, as a noted

\footnotetext{
${ }^{431}$ Abu'l Fazl, AN, III, pp. 106-7.

${ }^{432}$ Abu'l Fazl, AA, I, p. 289.

${ }^{433}$ Marshall, Bibliography, p. 241.

${ }^{434}$ Dara Shikuh, Majma ' al-Bahrain or The Mingling of the Two Oceans, M. Mahfuz al-Haq, ed. and tr., Calcutta:The Asiatic Society, 1982.
} 
calligrapher of nastaliq and nasksh, the beautifully copied out Quran Sharif. In his attempt to unite religious understandings he translated the Baghavadgita from Sanskrit into Persian, his version entitled the Ab-i Zindagi, retranslated the Sanskrit Mahabharata which had already been translated at the court of Akbar, and, two years before his death, fifty verses of the Upanishads, in a volume called the Sirr-i Akbar. ${ }^{435}$

The sons and daughters of Aurangzeb, himself a noted calligrapher, are said to have, "owing to [their] blessed character and the teaching of His Majesty," memorized the Qu 'ran, studied hadith and religious law, developed fluency in Turki, Persian and Arabic, and mastered the calligraphic scripts of nastaliq, naskh and shikastah. ${ }^{436}$ Aurangzeb's successor, the emperor Bahadur Shah, "spent the time of his youth mostly in acquiring learning and united theoretical knowledge to practice. ${ }^{\natural 37}$ Even the last Mughal emperor, Bahadur Shah Zafar, was a noted poet in Urdu, several collections of which are still extant. ${ }^{438}$ Although remarkably broad in scope, the education described by Mirza Haydar Dughlat in Timurid Khurasan seems representative of generations of princes of the Timurid-Mughal house, where equal emphasis was placed on the arts of the pen and those of the sword, and where the composition of poetry and the strategies of the hunt vied for princely attention.

\footnotetext{
${ }^{435}$ Ibid., pp. 4- 23, for a full list of Dara Shikuh's works of prose and poetry. See also Marshall, Bibliography, p. 127-9.

${ }^{436}$ Saqi Musta id Khan, Ma'asir-i Alamgiri, Jadunath Sarkar, tr., New Delhi: Munshiram Manoharlal Publishers Pvt. Lmt., 1986, p. 322.

${ }^{437}$ Ibid., p. 319.

${ }^{438}$ Marshall, Bibliography, p. 497.
} 


\section{Training Princes to Rule: The Imperial Appanage}

Yet as critical an imperial attribute as they considered their literacy, the princes of the Timurid- Mughal lineage represented potential rulers, and their military and political training was of necessity the most complex and multi-faceted component of their education. Concerned for the training of their princely sons, the Turkish and Mongol royal families of Central Asia included them in political life from an early age. Timur's sons and grandsons were married and had begun to take an active military and political role while still in their early teens. ${ }^{439}$ His two eldest sons, Jahangir and Umar Shaykh, had led regiments of their father's army while yet teens, and on their deaths, Jahangir's sons Muhammad Sultan and Pir Muhammad, and Umar Shaykh's sons Rustam and Iskandar took on important central roles in governing and expanding the empire. Nine of Timur's twenty-one tumens (large military units) were eventually led by his offspring. ${ }^{440}$ Military training through personal experience was central to the raising of a prince, but perhaps the most critical component of princely training, for Timur and for his descendants, was the assignment of a provincial governorship, following the traditional Mongol system of heritable divisions of imperial territory, the ulus, known in English as the appanage.

Political legitimacy for Chingiz Khan had included the conviction that "God had designated him the sole legitimate ruler of the world, and that he had transmitted

\footnotetext{
${ }^{439}$ Beatrice Manz, Rise and Rule of Tamerlane, p. 77.

${ }^{440}$ Ibid.. Manz warns her readers that the ten thousand soldiers each implied by the word tumen is an unlikely number and that perhaps not all tumens mentioned in the sources, nor soldiers in each tumen, in fact existed. Tumen perhaps should be taken to mean "a large military force."
} 
sovereignty to his descendants. ${ }^{441}$ In affirmation of their collective sovereignty and in keeping with Mongol tradition, he had divided his own empire among four of his sons and grandsons, each of whom was assigned an appanage. The family of the eldest, Jochi, was given the western portion of the empire; the second son, Chaghatay, received steppe Transoxiana; and Ogodei was given the territory east of Lake Balkhash. The youngest son, Tolui, received the Mongolian heartland of the empire, as well as Chingiz Khan's personal guard and the larger portion of his army; this was the usual share of the youngest heir and did not imply enhanced status. Although there were "constant quarrels," the Mongol Empire retained a high degree of unity and standardized administration, manning newly conquered territories with troops and representative administrators from each of the four otherwise independent uluses. ${ }^{442}$ Despite the inherent fissiparous qualities of the system, it held together for another thirty years until the death of Chingiz Khan's grandson, Mongke Khan, in 1259. It was then that a succession struggle between two of Mongke's brothers, eventually won by Kubilai, caused the confederation to collapse into competing Mongol khanates.

When Timur reunited large portions of the Mongol Empire, he conformed to Mongol tradition and asserted his descendants' collective legitimacy by partitioning his empire among his sons, assigning each an appanage to govern. ${ }^{43}$ Assigned in their youth to govern imperial provinces, the royal princes thereby developed such critical skills as learning to manage a treasury, organize a military force and represent the royal center in far-flung imperial provinces, although with varying degrees of autonomy.

\footnotetext{
${ }^{441}$ Douglas E. Streusand, The Formation of the Mughal Empire, Delhi: Oxford University Press, 1989, p. 29.

${ }^{442}$ Manz, Rise and Rule of Tamerlane, p. 4.
} 
Timur's biographer wrote of the training of the Great Amir's successors, and their efforts on his behalf, "Truly, difficult tasks had trained them and they had been fashioned by the efforts of Timur, who by their aid had opened closed doors and by their onslaughts widened narrow places and by their attacks escaped from the stress of every melee and by their constancy obtained what he needed and by their council reached the hidden treasures of his desires." ${ }^{444}$

While not in complete control of a near- autonomous ulus as the Chingizid princes had been, each of Timur's sons was serving as governor of a Timurid province at the time of Timur's death. The Timurid princes maintained their own provincial households modeled on that of the imperial court, including viziers, scribal staffs, tax collectors, kitabkhanas and artisanal workshops. Upon a prince's accession to the throne, his household was expected to serve as the nucleus of his imperial household, complete with all of its established internal networks of patronage and loyalty. ${ }^{445}$

Timur assigned amirs, or military commanders, to the household of each of his sons, each representing a variety of tribes or interest groups, or the relatives of Timur's own closest personal followers. In this way, the amirs, carefully positioned within the princely retinues, "were chosen to be representative of the whole ruling class," and the armies they led "mirrored the composition of the whole Chaghatay army." same time, the amirs assigned to princely courts and military units were carefully chosen allies of Timur, acting not so much as "servitors, but as guardians or watchdogs,"

\footnotetext{
${ }^{443}$ Ibid., p.15. Also Streusand, Formation of the Mughal Empire, p. 29.

${ }^{444}$ Ibn Arabshah, Tamerlane, pp. 241-2.

${ }^{445}$ Peirce, The Imperial Harem, p. 43.

${ }^{446}$ Manz, Rise and Rule of Tamerlane, pp. 84-5.
} 
restricting princely freedom of action. ${ }^{447}$ Their close personal ties to Timur indeed acted to trump the power of their immediate leader. When, at the age of fourteen, Timur's son Amiranshah was appointed to govern Khurasan, four powerful members of Timur's following were assigned to guide and guard him, although within the decade three had been reassigned, leaving only Aqbugha Nayman, one of Timur's most influential generals, to represent Timur's interests. ${ }^{448}$

Perhaps the most critical individual within the princely household was the ateke (also referred to as ataliq or atabeg). The office of ateke is a Central Asian Turkish tradition, although the particulars of the role are somewhat unclear in the sources. ${ }^{449}$ English-language translations of Mughal manuscripts render ateke as either "guardian",450 or "tutor," ${ }^{451}$ neither of which successfully describes the full range of the ateke's duties and powers. The ateke held very high status, and were often only slightly lesser members of the royal family. The Turkish etymology of the word can better suggest the significance of the office: ata, father, and eke, brother-hence, uncle, or a kind of surrogate father. ${ }^{452}$ Alternatively, ataliq can be translated as "fatherliness."

Atekes could be assigned to a prince as both guardian and tutor, but more specifically as paternal guide and advisor. Most importantly, the ateke was considered to be the representative of the ruler- father, looking after the interests of the sovereign rather than those of the individual prince, a fact which could at times lead to antagonistic

\footnotetext{
${ }^{447}$ Ibid., p. 86.

${ }^{448}$ Ibid.

${ }^{449}$ Reşit Rahmeti Arat, ed. and tr., Vekayi Babur'un Hatıiratı, Ankara: Tūrk Tarih Kurumu Basımevi, 1946, II, p. 579. As a Central Asian tradition, the office of ateke was common among many groups of Turkish and Mongol descent, such as the Aqquyunlus, Qaraquyyunlus, Seljuk Turks, Ottomans and Safavids, among others.

${ }^{450}$ As in Beveridge trans. of Humayunnama.

${ }^{451}$ As in Thackston trans., Jahangirnama.
} 
relationships between atekes and their princely wards. All princes seem to have been assigned atekes throughout the entire Timurid period in Mawarannahr, but whether they always retained them past their majority is unclear. In the case of very young princes it was assumed that the ateke would govern the province in the prince's name because, of course, legitimate sovereignty lay only within the royal dynastic line. In any case, the ateke was expected to acquire a great deal of power, which was often and infamously abused in the princely courts. ${ }^{453}$

While the princes served as provincial governors, their status remained ambiguous and their relative political autonomy was dependent on the degree of charismatic power held by the sovereign. Under Timur the princes were treated as extensions of the imperial center, leading armies and governing at the behest of their ruler. Their assignments were occasionally rotated, based on new territorial conquest or the death of an heir, thereby preventing them from cultivating local loyalties. ${ }^{454}$ The death of Muhammad Sultan in 1403 inspired Timur to break the empire into its final arrangement of four quarters, as had Chingiz Khan, each governed by the family of one of his sons. In the northwest quadrant, Amiranshah's sons controlled the ulus of Hulegu Khan: Khalil Sultan governed Baylaqan, Arran, Armenia and Georgia; Abu Bakr took Iraq, Kurdistan, Mardin, Diyarbakir, and the Oyirat tribe; while Umar governed Azerbaijan. Umar Shaykh had died in 1394, so his son Pir Muhammad governed the southeast quadrant, in Fars, while in the southwestern sector, Iskandar governed Hamadan, Nihawand, Burujird and Lur-i Kuchik, and Rustam governed Isfahan. In the

\footnotetext{
${ }^{452}$ Arat, Vekayi, II, pp. 579-80.

${ }^{453}$ Manz, Rise and Rule of Tamerlane, ch.7, "The Struggle for Succession."

${ }^{454}$ Ibid., p. 87.
} 
northeast quadrant, Shah Rukh governed Khurasan and his sons ruled to its north: Ibrahim Sultan ruled on the borders of Moghulistan, in Andijan and Kashghar, while Ulugh Beg ruled along the border of Turkestan, in Tashkent, Sayram and Ashbara. After Timur's death, when political authority in Central Asia became fragmented, many Timurid appanages developed into independent territories with only superficial allegiance to imperial successors, for the inherently fissiparous tendencies of the partitioning of empire could be controlled only by leadership capable of demanding complete personal loyalty. Because of his close proximity to the capital, Timur's grandson, Khalil Sultan (1384- 1411), was successful in seizing Samarqand immediately after his death, yet his uncles and brothers "looked for the end of this business," and Khalil Sultan "became of small account, and knew that he must be buffeted on every side by the waves of contention and that the waters of the kingdom would not be clear of trouble...." ${ }^{455}$ While the princes, their territories, treasuries, and armies were intended to be at the service of the emperor, in the absence of clear imperial authority they could emerge in support of a prince-governor, or rebellious amirs "pursuing their own ambition," or other charismatic contenders for power. ${ }^{456}$

The system of appanage assignments continued throughout the Timurid period in Mawarannahr. Babur's grandfather had split his territory into four smaller appanages, assigning one to each of his sons. When Babur's father died, the twelve-year-old inherited the paternal appanage of Ferghana, which he lost within a very few years to

\footnotetext{
${ }^{455}$ Ibn Arabshah, Tamerlane, p. 242. Khalil Sultan was the son of Miranshah (1367- 1408), Timur's third son.

${ }^{456}$ Lentz and Lowry, pp. 68 and 155.
} 
Uzbeks and uncles. Oddly, Babur's younger brother, Jahangir, seems to have inherited no territory at all; certainly he made regular attempts to take Ferghana for himself.

Having established himself in Kabul and India, Babur unhesitatingly applied the Timurid appanage system to his own sons. Shortly after his first successful campaigns into northern India, while on the road to Kabul, a letter reached Babur from Badakhshan that the governor of the province, Mirza Khan, had died, his son was too young to replace him, and the Uzbeks were near. As one might expect, the solution reached by Babur was completely Timurid in character: the young son of the deceased governor would inherit his father's patrimony while the politically critical governorship of Badakhshan was handed over to Babur's eldest son, the thirteen- year- old prince Humayun. ${ }^{457}$ A description of the preparations entailed in establishing a princely household is sadly lacking in the Mughal memoirs and chronicles, but Babur's daughter, Humayun's halfsister Gulbadan, wrote of the affectionate parents escorting their son to Badakhshan, where they "spent several days together. The Mirza remained and my royal father and my lady came back to Kabul."${ }^{, 458}$ Additionally, Babur writes that in Ferghana he had had an ateke, Shaykh Mezid Bey, with whom he had remained on very affectionate terms. All of Babur's sons were assigned Timurid-style atekes during their years in Kabul. ${ }^{459}$ Within the year Babur had conquered Qandahar, to which he immediately assigned his younger son, Mirza Kamran, as governor, while Babur again returned to the family in Kabul. ${ }^{460}$ In classic Timurid tradition, therefore, Babur's conquest of India was

${ }^{457}$ Humayunnama, p. 10. Babur's four sons were all born in Kabul: Humayun (1508- 1556), Askari (dates unknown), Hindal (1518- 1551) and Kamran (d. 1557), in addition to several daughters.

${ }^{458}$ Ibid., p. 11.

${ }^{459}$ Arat, Vekayi, II, p. 580.

${ }^{460}$ Humayunnama, p. 11. 
completed while his young sons served the empire as military leaders and governors of the provinces he had accrued. At the time of Babur's death in Agra his youngest son, Hindal was governing in Kabul. Hindal's lifelong ateke, Mir Hurd, on a visit to the imperial court, was at the deathbed of the ailing emperor whose anxious questions about his distant son illustrate the lengthy separations between parent and child. "How tall has Hindal Mirza grown?" the father asked, and, "What is he like?"461

In a letter to his successor, Humayun, Babur articulated his plans for a MongolTimurid system of appanages, by which he seems to mean princely rule over semiautonomous territories with one brother dominating. "If, by God's grace and favor," he wrote, "Balkh and Hissar are won and subdued, let one of your men stay in Hissar and one of Kamran's in Balkh. If, by God's grace and favor, Samarqand is also subdued, you will stay there yourself and, God willing, I will make Hissar royal demesne (khalsa). If Kamran thinks Balkh is small, write me. God willing, I will make up the deficiency to him out of those other territories... There were such conquests and victories while we were at Kabul that I consider Kabul my lucky piece (shukuntu tutubtur-i min) and have made it royal demesne. Let none of you covet it." ${ }^{462}$

That the Timurid pattern of childhood governorship continued to be considered a critical component of early Mughal princely administrative and military education in India was articulated clearly in Humayun's response to his own son, Akbar's, childhood appanage assignment. Although the captive boy prince had only just been restored to his parents after a rout of Kamran's army had left him again behind in camp, Akbar's childhood political training was immediately structured along traditional Timurid lines;

${ }^{461}$ Ibid., p. 22. 
the ten-year-old was assigned an administrative household and an appanage of his own to govern. On the death of his uncle Hindal "all the servants of Mirza Hindal, together with all his jagirs, viz., Ghaznan, etc. were assigned to him [Akbar], so that, by the practice of rule, he might exhibit favor and severity in the management of men; and $b y$ administration of a part, he might become accustomed to administer the whole." ${ }^{463}$ Having acquired a complete household staff and the appanage of Ghazni, Akbar was then sent on to "strengthen Kabul" and "practice the methods of spiritual and temporal authority."464

This was not intended to be a ceremonial role and it is clear that the childgovernor was expected to labor at his governorship. In Kabul, the prince's newly acquired staff found it necessary to write a complaint to Humayun, which led the ruler to gently instruct and admonish his ten-year-old son for racing pigeons and watching camel fights rather than administering the territory. "Sit not idle; "tis not the time for play, "tis the time for arts and for work," he chided. ${ }^{465}$ The combination of responsibilities described by the king illustrates clearly the continuity of values within the TimuridMughal dynasty, as Humayun emphasizes to his son the importance of participation in the arts as well as the labor of governance and military campaigning.

In December of 1551 Humayun determined to acquaint Akbar with his Ghazni appanage, "in order that his greatness be tested, that all might know his abilities, and also that he might practice the art of rule. ${ }^{, 466}$ His father assigned Khwaja Jalal al-din

\footnotetext{
${ }^{462}$ Baburnama, Mano, p. 558- 61, Thackston, tr., p. 741- 43.

${ }^{463}$ Abu'l Fazl, AN, I, p. 586. Italics mine.

${ }^{464}$ Ibid., p. 587.

${ }^{465}$ Ibid., p. 588.

466 Ibid., p. 596.
} 
Mahmud to be Akbar's ateke, responsible for the "general management" of Ghazni, though Akbar was expected to participate in the governance of his province. ${ }^{467}$ For most of the next four years, except briefly when Humayun had a hunting accident and Akbar was temporarily recalled to his father's court in Kabul, Akbar remained in his appanage of Ghazni, at his father's command. He did, however, accompany his father on his reconquest of Hindustan and had only recently been assigned the governorship of the Punjab at the time of his father's death in Delhi in 1555.

\section{Timurid Tanistry and the Mughal Princely Succession}

There were dangers in a training system for princes that allowed each to develop an independent patronage network, army and treasury, and this was further heightened by another Turco- Mongol tradition which had been carried to India and loyally maintained there by the Timurids: that of universal princely legitimacy, or tanistry. ${ }^{468}$ In the time of the Mongols the nomadic steppe cultures of Central Asia were organized around the basic clan units, patriarchal and agnatic, led by the hereditary military elite. While polygamy was practiced, sons of different wives were considered full brothers, thereby swelling the ranks of legitimate male contenders for power. Significantly, all male members of the elite held the right to claim political sovereignty. Leadership of the clan or confederation was confirmed by acknowledgment of members of the elite, but this was often not until after an internal battle had established which of the contenders was able to wrest power

\footnotetext{
${ }^{467}$ Ibid.

${ }^{468}$ Joseph Fletcher, “Turco- Mongolian Monarchic Traditions in the Ottoman Empire," Eucharistion, Harvard Ukrainian Studies, III-IV, 1979-80. Fletcher defines tanistry as a system of succession which allowed the "most talented male member of the royal clan" to inherit the throne, a system which emerged in
} 
and control away from his rivals. This method of establishing royal succession was marked by constant competition for power and fluid, shifting loyalties, which resulted in regular eruptions and the inevitable fragmentation of political authority. In its defense, tanistry often "resulted in the regular re-subjugation and reintegration of clans," affirming their social coherence among the otherwise centrifugal forces of steppe society, yet it too could operate as a centrifugal force, pushing loyalties out from the center. ${ }^{469}$ "In the presence of strong, charismatic leaders, such as Chingiz Khan or Timur, the right to political sovereignty found expression in the practice of appanage distribution among the male descendants, the principle of seniority of succession often being observed." ${ }^{, 470}$ In their absence, however, the competition for power by appanage-holding princes, each of whom claimed the right to rule, resulted in wars waged across the countryside.

Modern historians have suggested that later attempts by Mughal emperors in India to select their own legitimate successors was a "truly novel and far-reaching development, which had not been contemplated before within the Timurid-Mughal context, ${ }^{, 471}$ but from the earliest years of the Timurid dynasty, favorites had been chosen, nurtured and positioned to inherit the throne, only to ultimately fall under the onslaught of rival brothers and cousins on the death of the ruler. Timur himself had chosen a successor, his grandson Pir Muhammad Jahangir, to whom he had given the governorship of northern India, but inevitably Timur's death in 1405 was followed by fifteen years of succession struggles among his sons and grandsons, all of whom were valid political

such diverse non- steppe regions as sub-Saharan Africa and Southeast Asia. It was also used by the Celts, from whom the term "tanistry" is taken. Ibid., p. 239.

${ }^{469}$ Ibid.

${ }^{470}$ Subtelny, "Babur's Rival Relations," p. 106. 
candidates with independent bases of power and influence, anxious to assert their regional power. The empire Timur had partitioned among his sons fell quickly into extreme fragmentation and decentralization, as control of the political centers was contested by rival claimants.

Timur's son Shahrukh, the eventual victor in the post- Timur succession wars, had been governor of Khurasan, Sistan, and Mazandaran since 1396 and therefore had control over a large independent treasury and a stable military following. Before competing for the imperial capital, however, Shahrukh spent the first few years after Timur's death putting down local rebellions within his own province, most notably that of Sulaymanshah ibn $\mathrm{Da}$ ud, a member of the Timurid royal family and recently appointed governor of Rayy and Firuskuh, who had originally been appointed ateke to the twentyyear-old Shahrukh and sent with him to Khurasan as advisor and guardian.

The eventual combatants were drawn not only from among the descendants of Timur, but also from Central Asia's Chingizid Mongol groups, the Chaghatays of Mawarannahr and Mughulistan and the Jochid Uzbeks of the White Horde, who, within a hundred years, would come to be led by Babur's nemesis, Shibani Khan. Timur's emphasis on maintaining a closed elite had encouraged intermarriage within and among clans, leading to "a paradoxical situation by the turn of the fifteenth century where the most ardent of foes and the most despicable of traitors were often the closest of blood relations.",472 Timurid scholar Maria Subtelny writes, "It was not so much the succession of battles, victories, and defeats in themselves, as the continual political realignments

\footnotetext{
${ }^{471}$ Munis Faruqui, "Princes and Power in the Mughal Empire, 1569- 1657," unpublished PhD dissertation, Duke University, 2002, p. 34.

${ }^{472}$ Subtelny, "Babur's Rival Relations," p.107.
} 
among the numerous contenders for power that are such an outstanding feature of this period. Indeed, the very notions of loyalty and treason become almost impossible to define, for even personal retainers appear to have been free to leave their masters when it was expedient to do so.",473

Babur's family relationships reflected the complexity of intermarriage and loyalty, with the Chingizid Mongols represented on his mother's side, Timurid Turks on his father's, and Uzbeks more distantly by marriage. Ambitious and always aware of his own royal lineage and personal right to claim sovereignty, as a fifth-generation descendant of Timur, Babur spent his youth in repeated attempts to conquer the ancestral capital of the Timurids, Samarqand, and recover his lost appanage, Ferghana. His daughter later wrote of his struggle for supremacy, "For a full eleven years in the region of Mawarannahr his wars and exertions (jangha $u$ tiraddudat) against the Chaghatay and Timurid and Uzbek princes were such that the tongue of the pen is too powerless and feeble to enumerate them. ${ }^{\text {"47 }}$ The theme of his own political legitimacy runs as a constant narrative thread throughout Babur's memoir, including his insistent claims to the rulership of the lost Timurid patrimony of Samarqand and the detailing of careful negotiations determining rank and obeisance between himself and his royal Timurid cousins in Harat.

Tragically, Babur's sons inherited his ambition for not only dynastic but also personal sovereignty. Before his death, Babur had attempted to dispose equitably with the imperial territories, but long after Humayun had been publicly acknowledged as his successor, Babur enigmatically reminded his eldest son that he had always been expected

${ }^{473}$ Ibid., p. 104. 
to share with his brother Kamran; but share what? In a vague explanation of the intended territorial division, he wrote to Humayun, "You know that this rule has always been observed: six parts to you and five to Kamran. Always observe this rule yourself and do not break it." He then added, "Conduct yourself well with your younger brother. Elder brothers need to have restraint." 475

Yet Babur was uncomfortably aware of the weakness inherent in shared sovereignty. "Partnership in rule," he had written while in Kabul, "is a thing unheard of," ${ }^{476}$ and he twice quoted Sa di's Gulistan in his memoirs, "Dah darwish dar gilimi bakhuspanad, ve du padshah dar iqlimi nakunjanad (Ten poor men may sleep under one blanket, but two kings cannot fit into one clime"). ${ }^{477}$ Several other passages reflect his concern over shared power. When Babur heard that Sultan Husayn Bayqara was impressed by a companion, Muzaffar Barlas, and promised to set aside a third of their jointly conquered territory for him, he expressed confusion. "This was a strange promise," Babur mused, "When one is a king, how can it be right to make a subject coruler?" And significantly, he added, "One does not make such a promise to one's own brother or son, much less to a Beg." ${ }^{478}$ Yet while he so evidently appreciated the latent tensions in territorial divisions among the royal sons, Babur seemed driven to retain the traditional Timurid principle of partition of the empire, as well as accepting individual right to rule. The degree of political autonomy he intended for his sons in their provincial appanages, however, was not clear to anyone, least of all his successor Humayun.

\footnotetext{
${ }^{474}$ Humayunnama, p. 2.

${ }^{475}$ Baburnama, Mano, p. 558-9. Thackston, tr., p. 741-3.

${ }^{476}$ Ram Prasad Tripathi, "The Turko- Mongol Theory of Kingship," in The Mughal State, 1526- 1750, Alam and Subrahmanyam, eds., New Delhi: Oxford University Press, 1998.

${ }^{477}$ Baburnama, Mano, p. 187 and p. 285.
} 


\section{Humayun and the Failure of Imperial Partition}

Babur died in Agra in 1530, four years after conquering northern India. While he may have had hesitations regarding the governing abilities of his eldest son, Humayun, by the time of his death Babur had publicly confirmed Humayun as his chosen successor, formally committing their Timurid kin to his care. Like his father, and in the tradition of their Timurid ancestors, Humayun continued to use his brothers as projections of the imperial center, yet the princes had little loyalty to his sovereignty. In an examination of the subsequent rebellions of Humayun's brothers, it is clear that the princes were driven and inspired by their possession of royal blood and what were, in fact, nearly independent territories. While Humayun may have imagined his brothers to be provincial administrators at the command of the imperial center, they, as provincial governors in command of their own military forces, administrations, and treasuries, clearly thought themselves to be legitimate competitors for imperial sovereignty. In the absence of strongly charismatic central leadership, as had been evident in Timur and Babur, the system of princely appanage, coupled with a general acceptance of universal rights to sovereignty, was divisive, threatening the unity of the fledgling empire.

As Babur had requested, the khutba was read in Humayun's name in Delhi, Kabul, and Ghazni, affirming his role as first among equals, after which the empire was divided amongst the princes. Kamran demanded and received the lion's share, Kabul, where he began to form an autonomous regional government, most significantly striking coins and having the khutba read in his own name. When, pursued by his Afghan nemesis, Shir Khan (Shah), Humayun required passage through Kabul, he politely

${ }^{478}$ Ibid., Mano, p. 264. Thackston, tr., p. $353 . \quad 179$ 
requested entry to the region, acknowledging Kamran's near-sovereign status in Kabul with a surprising passivity, seeming to accept his brother's claims to autonomy, although Babur himself had clearly articulated Kabul's status as royal demesne. Not surprisingly, Kamran arrogantly rejected his brother's request: "In his lifetime the Emperor Firdaus Makani [Babur] gave Kabul to my mother [Gulrukh Begim]. It is not right for you to go to Kabul." Rather than face his brother's "large following," Humayun chose to lead his army on the more difficult march around Kabul and its environs, while bitterly commenting, "What was the good of my courtesy (insaniyat) in showing kindness (mihrbani) and brotherliness (biradari) to the Mirza [Kamran], if he is now talking to me in this way?" ${ }^{479}$

In a migration reminiscent of his father's years of wandering, as his inheritance disintegrated all around him, Humayun led his army through the territories of Mughal princes and amirs, some of whom welcomed and fed the emperor's forces while others refused to admit them. Meanwhile his brothers conspired over imperial territory, with Askeri in his province of Ghazni and Kamran in Kabul speculating over a joint conquest of Qandahar, then held by Hindal in Humayun's name. ${ }^{480}$ Humayun was "stupefied and bewildered (mutahayir u mutafakir)," recognizing the threat to imperial unity and yet unwilling to attack his brothers. ${ }^{481}$ Finally forced to ask his aunt Khanzada Begim to intercede on his behalf, he requested she go to the rebellious princes. "Tell them that the Uzbegs and the Turcomans are near them, and in this current situation, it would be better to be of one mind amongst ourselves. If Mirza Kamran will agree to carry out what I

\footnotetext{
${ }^{479}$ Humayunnama, p. 50.

${ }^{480}$ Ibid., p. 61.

${ }^{481}$ Ibid., p. 65.
} 
have written to him, I will do those very things that his heart desires. ${ }^{, 482}$ But Kamran proceeded to besiege Qandahar and eventually was successful in having the khutba read there in his own name, the traditional expression of independent sovereignty.

Significantly, the rebel Kamran took on the rights and responsibilities of a Great Khan by immediately assigning appanages to his two other brothers in the territory to which he had claimed imperial rights-- Kabul, Ghazni, Qandahar, Khutlan and Badakhshan-- as part of an effort to claim fraternal allegiance and co-opt his brothers' services. Mirza Askeri was given Qandahar and Mirza Hindal was given Ghazni. Hindal, however, attempted to withdraw into seclusion in Badakhshan, seemingly in repudiation of his brothers' rebellion, and so lost the appanage, was captured by Kamran, and kept under guard in Kabul. Meanwhile, Humayun's eventual flight from his brother Mirza Askeri, leading a force of two thousand troops, was so frantic that his own young son, the future emperor Akbar, was left behind to be taken hostage by his uncle.

It is interesting to note that when, after a nine-year exile from his former empire, Humayun returned at the head of an army, his earliest efforts at empire-building were directed not toward his lost patrimony in northern India but in the direction of the more favored territories of Balkh and Samarqand. Here again the disloyal machinations of Kamran frustrated Humayun's attempts at conquest until finally Humayun turned south with his Persian armies to re- conquer Delhi. Like his father Babur, Humayun seems to have conquered the Indian territories with a degree of reluctance, viewing them as inferior to the ancestral homelands of Central Asia, although Humayun, born in Kabul, had never seen Samarqand.

${ }^{482}$ Ibid., p. 61-2. 
As Humayun's advisors knew, the stability of his reclaimed kingdom was dependent on the destruction of Kamran, their younger brothers Askeri and Hindal having already been killed in battle, though on opposing sides of the familial conflict. Humayun's extreme reluctance to deal conclusively with the threat, perhaps as an act of filial obedience in remembering his father's injunctions to take care of his younger brother, caused a near mutiny within his immediate circle. Legal opinions were brought forward to support the execution of Kamran, but when Humayun continued to refuse, a compromise was reached. Kamran was not killed but blinded, disqualifying him for sovereignty, and was exiled to Mecca. With the internal threat finally removed, Humayun was able to position his son Akbar to inherit their fragile northern Indian kingdom nearly unopposed before his own accidental death in $1556 .^{483}$

Humayun's son Akbar was fortunate to mount the throne with almost no competition, for his uncles had at last been disposed of and his half- brother, Mirza Muhammad Hakim, was as yet too young to contest the throne. By the time Mirza Hakim had grown to adulthood, again very much in the model of his Timurid forebears, as the near-independent governor of the appanage of Kabul, ambitious and ready to challenge the emperor for sovereignty, Akbar had become politically entrenched and was powerful enough to destroy his brother's aspirations at little risk to his own sovereignty. In the classic Timurid- Mughal pattern of familial tolerance, notable in every generation, ${ }^{484}$ the

\footnotetext{
${ }^{483}$ Humayun was reading in the squat, two- story library tower of Purana Qila, the complex built in Delhi by Shir Shah on the site of Humayun's own earlier palace complex, which he had called Din Panah. Upon hearing the call to prayer, Humayun rose to his feet and rushed to exit the building. Tripping on the hem of his robe, he fell down the stairway and was killed.

${ }^{484}$ The exception is, of course, the accession of Shah Jahan, who acknowledged the continued relevance of the principle of tanistry through the immediate order to murder of all of his male relatives, even those who were too young to seem an immediate threat to the throne. His own successor, Aurangzeb, also carefully rid himself of rivals but those not killed outright in actual succession battles were "legally" executed as
} 
powerful Akbar was even able to forgive his rebellious half- brother, commenting, "Mirza Hakim is a memorial of the Emperor Humayun. Though he has acted ungratefully, I can be no other than forbearing. Some bold spirits asked permission to lie in ambush and put an end to that rebel. I could not consent, thinking it remote from what was befitting in his regard." ${ }^{485}$

Akbar and the Princely Appanage: Timurid Traditions Transformed

It is in the upbringing of Akbar's sons that we can identify the only Mughal modifications of the traditional political and military training of princes: the disappearance of childhood appanages and a vastly accelerated rotation of princely military assignments and governorships. The sources are regrettably silent regarding these adaptations of Timurid tradition and we can only guess that Akbar was influenced by his own sudden thrust at age ten into the responsibility and isolation of the governorship of a Mughal province. Perhaps, too, the example of his father's desperate struggles to retain sovereignty made an impact on the child. Raised in the household of a seditious uncle, twice left behind in the confusion and terror of a military rout, Akbar was witness to the disastrous impact of imperial partition on the royal succession. While not enough to compel him to completely forgo or transform the tradition of princely training through the assignment of governorships, his childhood experiences may have influenced the emperor's decision to keep his young sons close at hand and dependent on their father.

demanded by a public court order the emperor had requested and, of course, received. See below, this chapter. 
Without explanation or much comment of any kind, the usually verbose Abu'l Fazl writes only that "the wise sovereign kept his children under his own care and did not appoint any guardian to them, and was continually educating them in the most excellent manner of which there are few instances in ancient times." ${ }^{, 46}$ Although the princes were, as noted, assigned tutors at age four years, four months and four days, in the traditional Timurid manner, Abu'l Fazl describes their father's influence and example as the real basis of their education. Referring to Akbar's eldest son, Salim, Abu'l Fazl writes, "Constantly acquiring various outward and inward excellencies in the society of His Majesty and in the Shahinshah's entourage.... by the blessing of His Majesty's holy spirit and of his exalted attentions he [Salim] learnt the rules of justice and the cherishing of subjects and the principles of settling disputes."

Akbar's sons, Salim (1569- 1627), Shah Murad (1570- 1598) and Danyal (15721604), were not given appanages in their youth, signaling the permanent abandonment of this practice among the Mughals. ${ }^{488}$ The system of atekes remained in place, but Abu'1 Fazl describes the atekes assigned to Akbar's sons as tutors, and the boys seem to have remained almost exclusively in their father's household while under the training of these men. ${ }^{489}$ The atekes were chosen, in classic Timurid style, for their personal loyalties to

\footnotetext{
${ }^{485}$ Abu'l Fazl, AA, III, pp. 428-9. Akbar's forgiveness did not extend to Mirza Hakim's sons. When their father died of alcohol poisoning in 1585, Akbar refused a position of substantial power to any of the three. ${ }^{486}$ Ibid., p. 105.

${ }^{487}$ Abu'l Fazl, AN, III, p. 105.

For an alternative view of Akbar's talents as a father, see Fr Monserrate, who wrote that "The king's nature is such that, though he loved his children very dearly, he used to give them orders rather roughly whenever he wanted anything done; and he sometimes punished them with harsh blows as well as harsh words." The Commentary of Father Monserrate, tr. by J.S. Hoyland and annotated by S.N. Bannerjee, Cuttack, 1922, p. 53.

${ }^{488}$ They were, of course, assigned income-producing properties, jagirs, but as children were not expected to govern these territories themselves, but merely to profit from them.

${ }^{489}$ Abu'l Fazl, AN, III, p. 288.
} 
the emperor; the brothers of Akbar's own childhood ateke and loyal supporter, Shams alDin Khan, served the emperor's sons; Qutb al-Din Khan became Salim's ateke in 1577 and Sharif Khan as Murad's, in $1580 .{ }^{490}$ Shams al-Din Khan's wife had been Akbar's wetnurse (anaga), which made their son, Mirza Aziz, a milk brother (koka) of the emperor and an important notable of the imperial court. The atekes' positions were not always permanent, but their high rank at court and personal loyalty to the emperor determined their choice. Danyal was assigned Sa ${ }^{\circ}$ id Khan Chaghatay ${ }^{491}$ as ateke in 1577 and then Shaykh Fayzi, a court favorite, poet and brother of Akbar's closest friend and panegyrist, Abu'l Fazl, in 1579. Salim was assigned Akbar's loyal ally, Mirza Khan Abd al-Rahman Khan-i Khanan, in 1582.

Remaining at court, without active participatory governorships, the princes were nevertheless given positions of high rank at very early ages, although their titles were merely ceremonial. For example, in 1576, Akbar gave seven-year-old Salim authority over the entire Mughal army along with the rank of commander of 10, 000, while Murad was assigned the rank of 7,000 and Danyal 6,000. ${ }^{492}$ As none within the nobility could aspire to a rank higher than 5000 , this established the princes as the elite among all Mughal nobles. When in 1580 the province of Ajmer seemed to require the presence of Mughal royalty, the child-prince Danyal was sent, accompanied by "other intimate courtiers," to distribute royal gifts and "display abundant liberality" but immediately

\footnotetext{
${ }^{490}$ Shaykh Farid Bhukhari, Zakhirat al-Khawanin, Ziya al-Din Desai, tr., Delhi, 1993, I, p. 58, cited in Faruqui, p. 43- 4.

${ }^{491}$ Sa ${ }^{\prime}$ id Khan Chaghatay descended from a line of Timurid military men in Transoxiana. His grandfather, Ibrahim Beg Chabuq, had come to India in the service of Humayun, and his father had served Akbar. Nawaz Khan, Ma'athir ul-Umara, II, pp. 679- 82.

${ }^{492}$ Abu'l Fazl, AN, III, p. 308.
} 
afterwards he was recalled to his father's court to offer homage. ${ }^{493}$ In the same year, when Akbar planned a military expedition in the Punjab, eleven-year-old Salim begged to be included, and eight-year-old Danyal remained at court as the representative of imperial authority.

Nor was the status of a princely appanage ever again in doubt, as it had been at the time of Babur's death. From the time of Akbar and through the reigns of his successors, leadership roles and governorships were assigned only to adult princes, careful constant oversight was maintained by the emperor, and princely assignments were continually and regularly rotated. In an obvious effort to impose paternal control, Jahangir's sons serving their father away from the imperial court were recalled at least annually to pay homage. In exchange for their demonstrations of fealty, the giving of magnificent gifts and affirmations of loyalty and even servility, they were regularly assigned larger incomes, higher titles, and new military or governing assignments. Because princes and their enormous personal retinues were kept far more often at court than their ancestors had been, many of the great cities of the empire contained not only the imperial palace but, nearby, the only slightly less lavish palaces of the royal princes, many of which had been built at the expense of the emperor. ${ }^{494}$

Imperial oversight, through the unapologetic use of spies and informants, continued even when the princes were given leave to depart the imperial presence for distant assignments. In letters written to his sons, the sixth Mughal emperor, Aurangzeb, makes it clear that the sovereign received regular reports from his own agents within the princely households. He is able to comment on his sons' every appointment and make

${ }^{493}$ Ibid., pp. 463-4. 
recommendations of his own; writing to his heir apparent, Shah Bahadur, "You have appointed Aman Allah Beg, the superintendent of the artillery and of the palace, the police officer of Navah. He gave patel-ships to his dishonest and corrupt relatives. The oppressed cannot complain to you against his power. Alas! Alas! You should send to the province reliable and cautious reporters, and send me daily reports of the results of the orders [issued by you]." ${ }^{, 495}$

Mughal princes continued to be employed as extensions of the imperial center, but never again were they allowed to assume independent personal autonomy. Beginning with Abu'l Fazl, the chronicles describe Mughal princes spending their entire childhood in their father's household, serving the empire as symbols of imperial might and majesty, but lacking real sources of personal authority, often well into their twenties and certainly long after their marriages.

As for the assignment of atekes, scholars have assumed in the past that Mughal princes outgrew their surrogate fathers as their training was completed. "In the beginning they had an experienced officer associated with them, who trained them to deal with administrative affairs, but as soon as the training was complete, they were given independent charge." ${ }^{, 96}$ In fact, this does not accurately represent the post-Akbar period, when atekes, as representatives of the sovereign/ father in the households of his sons, continued to be assigned to the princes well into adulthood. For example, in 1598, when Shah Murad was temporarily assigned a territory in Gujarat, his ateke died. The father of

\footnotetext{
${ }^{494}$ Inayat Khan, Shah Jahan Nama, p. 537.

${ }^{495}$ Ruka 'at-i Alamgiri, Jamshid H. Bilmoria, ed.,Delhi: Idarah-i Adabiyat-i Delli, 1972, pp. 40- 41.

${ }^{496}$ H.K. Naqvi, History of Mughal Government and Administration, Delhi: Kanishka Publishing House, 1990, p. 65. Also, "The Timurid-Mughal tradition demanded an end to the appointment of ataliqs once princes attained adult status," in Faruqui, "Princes and Power," p. 46.
} 
the then twenty-seven-year-old prince immediately appointed Mirza Yusuf Khan to be his son's new ateke. ${ }^{497}$

Atekes, Naukars, Allies

The power accrued by ownership of an appanage had encouraged Timurid princes to act on individual claims to sovereign legitimacy, yet the changes instituted in sixteenth-century India did not serve as a corrective; among post-Akbar Mughal princes, no longer assigned childhood appanages, succession wars continued unabated. And why not? Even without the political and military independence which sprang from control of a traditional Timurid semi- autonomous governorship in the imperial provinces, the princes were so often employed as extensions of the state that by middle age they were usually experienced administrators and hardened military commanders, each possessed of a complete imperial household, positioned to command his own networks of loyalty and patronage, and confident in his individual right to rule.

With the expectation of deadly succession wars immediately following their father's death, the princes were encouraged throughout their adulthood to form strategic relationships. A contemporary witness wrote, "When these princes once leave the paternal house, they work and scheme to make themselves friends. They write secretly to the Hindu princes and the Mahometan generals, promising them that when they become king they will raise their allowances." ${ }^{, 498}$ As late as the time of Aurangzeb's sons and later, chroniclers record their constant jockeying for influence by developing

\footnotetext{
${ }^{497}$ Abu'l Fazl, AA, III, p. 1081.

${ }^{498}$ Niccolao Manucci, Memoirs of the Mogul Court, Michael Edwardes, tr., London: Folio Society, 1957, pp. 37-8.
} 
relationships with influential courtiers and political allies. Each prince acted by "softening the rigor of government against those who labored under its displeasure; thinking that thus obliged by his mediation, they would readily return his favors, by embracing his cause whenever the death of his father should give him a claim to the empire., ${ }^{499}$

There is no doubt that mature Mughal princes were eager to establish alliances with influential individuals at court, powerful factions, tribal and caste leaders, political and military families, but their royal fathers participated in the process, carefully positioning their favorites to achieve critical alliances through the careful assignment of atekes, marriage partners and military companions. Timur had carefully placed each of his heirs in the path of prominent courtiers and military leaders, insisting on the formation of relationships which could, eventually, survive his own death and offer the prince a life-saving alliance. So too in India, Mughal fathers married their sons into the families of influential and powerful amirs and allies, establishing for them a body of allies which could come to the prince's aid, provided, of course, that the prince acted carefully to maintain those alliances. There were no guarantees. Shahnawaz Khan Safavi ${ }^{500}$ had as sons-in-law three royal Mughal brothers, the sons of Shah Jahan: Shah Shuja (1615-1659), Aurangzeb (1618-1707) and Murad Baksh (1619- 1661), yet remained neutral in the early stages of the succession war which broke out between them in the 1650 's. He finally joined with the one brother who had not married into his own

\footnotetext{
${ }^{499}$ Iradat Khan, Tarikh-i Iradat Khan, E\&D, VII, p. 555.

${ }^{500}$ Of noble descent, son of Mirza Rustam of Qandahar, Shah Nawaz Khan was made ateke to Shah Jahan's son, prince Murad Baksh, at the time of his assignment to the Deccan. On his death in the succession wars, because of his royal lineage, Shah Nawaz Khan Safavi was buried in the shrine of Mu'in al-Din Chishti in Delhi on orders of Emperor Aurangzeb. Ma'athir ul-Umara, II, p. 767- 71.
} 
family, Dara Shikuh (1615- 1659), and died defending him in 1659 at the Battle of Ajmer. ${ }^{501}$ Yet more often healthy and lifelong alliances were formed by the princes, often with the connivance of their father, and each potential ruler as backed by a powerful faction of supporters who could be trusted to support his claims to the Mughal throne. Princes even scavenged among their father's own courtiers for followers. Jahangir refers to individuals he had "chosen and requested" from his father's service, promoting them within his personal household..$^{502}$

While much of a prince's retinue was originally appointed by his father, for the most part the following a prince established remained for the most part with him throughout his lifetime, becoming increasingly independent of the father's wishes and on some occasions far more loyal to the prince's survival than were the prince's own relatives. The memoirs of Jahangir affirm the increasing partisanship of the princes' atekes and refer regularly to the naukar of his sons. In the Mongol period, the term naukar had been used to describe a military alliance and personal fealty, but over time it gradually came to imply ever closer ties of loyalty and service. ${ }^{503}$ As used by Jahangir, it is a clear illustration of the independent nature and loyalty of the princely personal retinues. ${ }^{504}$ The loyalty of a prince's allies could be powerful. In the succession war that led to Shah Jahan's deposition, when the defeated prince Murad Bakhsh was captured by his brother Aurangzeb, so concerned was the victor about the strength of his defeated

\footnotetext{
${ }^{501}$ Faruqui, "Princes and Power," p. 12.

${ }^{502}$ Jahangirnama, p. 14. Jahangir took over the patronage of Mirza Sultan, the son of Mirza Shahrukh, a Timurid descendant through the line of Mirza Sultan Abu Sa id and governor of Badakhshan.

${ }^{503}$ In modern Persian, naukar has come to mean "servant," indicating a trend in definition towards increasingly personal loyalty.

${ }^{504}$ Jahangirnama, pp. 294 and 403. The size of the retinues developed by the adult princes could be enormous. It has been estimated that by the 1580's Salim's personal household reached 30, 000 people:
} 
brother's followers that he used four decoy elephants to confuse the prince's partisans, making it all but impossible for them to "fall upon the howda in which he was confined" and rescue him. ${ }^{505}$

\section{Adapted Succession Traditions Among Mughal Contemporaries}

The Mughal wars of succession exploded with the pent-up force of long awaited collisions between rivals and their allies, in part because along with the diminution of princely political autonomy, the Mughal emperors of the sixteenth and seventeenth centuries achieved remarkably lengthy reigns of twenty-two to forty-nine years. Akbar reigned from 1556 to 1605 , Jahangir from 1605 to 1627, Shah Jahan from 1627 to 1659 and Aurangzeb nearly matched Akbar's forty-nine years, ruling from 1659 until 1707. These extended reigns must have increased the tension at court and tried the patience of all ambitious, highly trained Mughal princes with political aspirations. So while sixteenth- century modifications may have reduced princely access to the potential source of power that was the Timurid appanage, thereby averting declarations of territorial autonomy such as that of Humayun's rebellious brother Kamran, the princes' awareness of their own political viability, the sophistication of their personal patronage networks, and their highly developed administrative and military skills, learned in adulthood in their role as extensions of imperial power, were frustrated by heightened paternal control, even well into middle age. It is, therefore, no wonder that tensions and conflicts over sovereignty continued to rock the post- Akbar Mughal court.

6,000 horsemen and 24,000 retainers, in addition to the personnel required to service these multitudes. See Faruqui, "Princes and Power," p. 51.

${ }^{505}$ Muhammad Hashim Khafi Khan, Muntakhab 'ul-Lubab (Tarikh-i Khafi Khan), E\&D, VII, p. 229. 
Confronted with similar dilemmas, and sharing something of the same Turkic Central Asian origins, the Ottomans and Safavids gradually modified their original succession principles dramatically. Extremely destructive succession wars marked their early centuries, such as the twenty years of divisive rivalry between Bayezid's sons in the period just after Timur's successful invasion of Anatolia in the early fifteenth century. Beginning with the reign of the Ottoman sultan Murad I (r. 1362- 89) and through the beginning of the seventeenth century, Ottoman rulers destroyed any possible rivalry by executing all princes of the royal blood immediately on achieving the throne. Murad I's near-contemporary, the Ottoman poet Ahmedi, explained:

His brothers became enemies to him The affairs of all of them were ended at his hands They were all destroyed by the sword. ${ }^{506}$

An attempt by Mehmed I (r. 1413- 20) to divide the Ottoman Empire amongst his sons, hoping thereby to prevent war between brothers, was skillfully outmaneuvered by an influential palace faction and the subsequent succession battle raged for three years. ${ }^{507}$ The Ottoman sultan Mehmed II (r. 1421- 1451) attempted to avoid these disastrous succession rivalries by making accessional fratricide an institutionalized part of the Ottoman kanun. It may be that, as conqueror of Constantinople, Mehmed II was less concerned with the dangers of adaptations to old traditions than were his predecessors. When his son Bayezid abdicated the throne, his successor, Selim, desperate to avoid threats to his authority, had not only all of his brothers but his nephews killed as well. So anxious was he to manipulate and subvert the tradition of tanistry that he eventually

\footnotetext{
${ }^{506}$ Colin Imber, The Ottoman Empire, 1300- 1650, NY: Palgrave Macmillan, 2002, p. 97.

${ }^{507}$ Ibid., p. 99.
} 
killed all of his own sons, leaving alive only his chosen successor, Suleyman (r. 15201566).

Although the modified system resulted in regular bloodshed, it was understandably successful in preventing fratricidal rivalries. In addition to continuing the now-institutional accessional fratricide, Suleyman's successor Selim II (1524- 1574) made a further major adaptation by entirely abandoning the Central Asian system of appanages that gave the imperial princes an opportunity to develop their own households, create networks of influence and patronage, and gain political and military experience. From that time the princes would remain in the imperial household, living entirely within a suite of apartments in the rear of the harem, which came to be known as the kafes, the cage. Isolated from public life, the princes were not allowed to father children, establish a public identity, or develop the retinue that might support princely aspirations to the throne. Like his Ottoman contemporaries, the Persian Shah Abbas adopted accessional fratricide and instituted a Safavid kafes, isolating the princes in the family quarters of the imperial palace. In a desperate bid for absolute sovereignty, Abbas eventually had all of his brothers and sons killed or blinded, nearly destroying the dynasty, to be finally succeeded by a grandson.

It was in the very early seventeenth century, under the Ottoman sultan Mustafa I, that the practice of accessional fratricide lapsed, and along with it the rule that succession must run from ruler to son. Instead succession followed a simple system of seniority, sovereignty shifting to the ruler's brother, uncle, nephew, in a style reminiscent of preTimurid Central Asian traditions. Male members of the dynasty continued to be limited to a life within the imperial household and the dangerously empowering tradition of 
princely governorships was never reinstituted. Succession conflicts, and the princes at their center, henceforth remained confined within the palace. ${ }^{508}$

Diplomatic exchange among these contemporary Turco-Persian empires was enough to ensure that the Mughals were aware of the alterations made to Ottoman and Safavid succession patterns. Akbar and Jahangir expressed personal horror at the bloody family dramas of their rivals while their own wildly destructive succession wars continued to rage across the subcontinent. For while relatively minor changes can be identified within the related Mughal institution of the princely appanage, the fundamental Timurid- Mughal succession tradition based on a firm adherence to the principle of universal sovereignty, tanistry, remained firmly in place. Occasional attempts were made to manipulate the Mughal succession, by assigning an official successor to whom loyalty would be guaranteed, even base the inheritance of power on seniority or primogeniture, but these schemes came to nothing. Rejecting one such plot to assign early sovereignty, Akbar's courtiers, themselves “descended from an ancient and illustrious Mughal family," declared, "This is contrary to the laws and customs of the Chaghatay Tartars and shall never be." ${ }^{509}$ Although it provoked devastating wars among brothers and produced an indirect dynastic line, the principle of tanistry remained firmly in place in India, forming a critical link to the Timurid steppe heritage, and defining individual rights to sovereignty and Mughal dynastic political legitimacy.

\footnotetext{
${ }^{508}$ See Peirce, The Imperial Harem and Imber, Ottoman Empire, for a discussion of the Ottoman succession. See Roger Savory, Iran Under the Safavids, Cambridge: Cambridge University Press, 1980 and H.R. Roemer, "The Safavids," Cambridge History of Iran, Vol. 6: The Timurid and Safavid Periods, Peter Jackson and Lawrence Lockhart, eds., Cambridge University Press, 1986, for information regarding the Safavid succession.
} 
Restless Princes, Fratricide, and Timurid Imperial Partition

No mention of any assignment to a governorship occurs in Jahangir's memoirs until 1598, when his father departed for the Deccan and awarded his son, the favorite and chosen successor, the province of Ajmer. ${ }^{510}$ The prince was then already twenty-nine years old. He handled independence badly, committing serious acts of sedition, including the outrageous murder of his father's friend and biographer, before being brought to heel again by his father. Yet Jahangir's panegyrist insisted that Akbar was not entirely displeased by his insurrections, for 'through this act His Highness's [Jahangir's] bravery and manliness were noticed."

His two brothers, Danyal and Murad, had died young from "overindulgence in wine" but Jahangir's succession came to be contested by his own son, Khusraw, who felt he had been Akbar's heir apparent. ${ }^{512}$ In a notable commentary on the Mughal succession, Khusraw justified his filial insubordination by asserting, "I shall certainly not become more criminal by taking arms against Jahangir than he himself was in revolting against Akbar. If I offend, it will only be by following the example of my father."

The emperor Jahangir composed bitter verses in response to the disloyalty of the royal princes:

Who could have known that this youth of tender years would in this way plot mischief against his elders?

With the first goblet he brought forth the dregs,

\footnotetext{
${ }^{509}$ Asad Beg, Wikaya-i Asad Beg, E\&D, VI, p. 170.

${ }^{510}$ Muhammad Hadi, Preface to Jahangirnama, Thackston, tr., p. 8.

511 Ibid., p. 11.

512 Ibid., p. 18.

${ }^{513}$ Ram Prasad Khosla, Mughal Kingship and Nobility, Delhi: Idarah-i Adabiyat-i Delli, 1976, p. 100. Italics mine.
} 
bypassing my grandeur and his own shame.

He burned the throne of the sun

in desiring the place of Jamshid. ${ }^{514}$

\section{Ki danast kin kudak khurd sal shud ba bazurgan chunin bad sigal. \\ Ba avval qad' durdi arad guzarad shukuh-i man u sharm khuwish. \\ Ba suzand aurang-i khurshid ra, tamana kunad jay Jamshid ra.}

At either end of his twenty-two year reign, Jahangir's restless and ambitious sons engaged in bloody rebellions, both of which were eventually defeated but at a high cost. Less than a year after Jahangir had ascended the throne, on the sixth of April 1606, Khusraw went into rebellion. As Khusraw fled westward his undisciplined army swelled with the ranks of the disaffected, and plundered the countryside. While passing through the Punjab, Khusraw begged for financial assistance from the Sikh patriarch, Guru Arjun Singh (1581- 1606). The guru finally offered the desperate prince a charitable gift of 5000 rupees, which Jahangir was later to interpret as support for the princely rebellion and punish by executing the guru, in what would prove to be a divisive moment in the history of Mughal- Sikh relations.

Jahangir rapidly quelled his son's rebellion. Although members of the imperial elite were generally forgiven, three hundred of the captured peasant- soldiers of his son's

\footnotetext{
${ }^{514}$ Jahangirnama, p. 38, Thackston, tr., p. 55. Jamshid is among the pre-Islamic kings of Iran listed in Ferdowsi's Shahnama. Jamshid's reputation for justice made him an imperial icon within the Persian speaking world. The imagery of his cup has generally been interpreted as "an emblem of mystical gnosis and divine love," but as it was employed by the favorite poet of the Jahangiri Mughal court, the medieval Persian composer of ghazals, Hafiz, the "cup of Jamshid" has a courtly context, both generally and more specifically to signify the transience of kingly power and glory" (See Julie Scott Meisami, Medieval Persian Court Poetry, Princeton, NJ: Princeton University Press, 1987, p. 288, f. 70). Surely it is this interpretation which inspired Jahangir's evocation of pre- Islamic Persianate kingship. In a certainly deliberate play on words, the name Khurshid is here translated as sun, but it was also the name of the mistress of Jamshid, see F. Steingass, Persian-English Dictionary, New Delhi: Munshiram Manoharlal Publishers, Pvt., 2000, p. 484.
} 
army were impaled alive, forming an avenue along which Khusraw was led on elephantback in order to review the anguish of his followers. Only one year later Khusraw again became involved in a plot to overthrow his father's rule, but in this case a member of the cabal informed Jahangir of the plot. He was easily able to crush the conspiracy and execute the ringleaders. Following the pattern of remarkable intra-familial tolerance displayed by Babur, Humayun and Akbar, under threat of their rebellious brothers, even yet, after two acts of open rebellion, Jahangir could not bring himself to destroy his son. Khusraw was blinded and imprisoned, yet eventually, with the contrivance of his aunts, he was guardedly pardoned, doctors were called to attend to his blinded eyes, partial sight was restored, and he was yet again allowed to wait on his father. His depression and intransigence, though, prevented him from endearing himself to Jahangir, who eventually assigned him to the care of his equally ambitious younger brother, Khurram, the future Emperor Shah Jahan. Khusraw died under somewhat mysterious circumstances while in the custody of Khurram in 1622 in Burhanpur.

Khurram, Jahangir's third son, remained at court until the age of twenty-two, "when the signs of bravery were resplendent from the auspicious face of His Majesty" and he was finally appointed to lead a military expedition to Ajmer. ${ }^{515}$ In affirmation of the relatively late age at which the prince was assigned a role outside of the palace, when Khurram's ateke, Khan Azam, began behaving "uncooperatively," he was sent a letter from the emperor, remonstrating "At your advice I sent the imperial banners to Ajmer. Now that you have reasonably entreated me for the prince, and everything has been done as you advised and approved, what is wrong? .... I sent Baba Khurram, from whom I have

${ }^{515}$ Muhammad Hadi, Preface, p.6. 
never been separated (Baba Khurram ra ki dar in muddat hargaz az khud juda nasakhte budam), simply because I had confidence in your abilities." ${ }^{\text {516 }}$

Khurram's brilliance as a military leader in campaigns in the Deccan and Gujarat led his father to honor him with new titles, first Shah Sultan Khurram and, soon after, Shah Jahan (King of the World), and a special seat near his father's throne. He seems to have cultivated a fair degree of political influence and authority both at court and in the provinces, which he, like his father, eventually abused. At age thirty, his increasingly rebellious acts drove his father to re-name him "bidawlat" (unfortunate; wretched), adding in his manuscript, "And every place in this iqbalnama [auspicious tale] 'bidawlat' is mentioned, it will mean him.. ${ }^{, 517}$ In irritation, Jahangir even returned to hunting, which he had foresworn five years earlier for the benefit of Khurram's ailing son. ${ }^{518}$ In his remarkably human memoir, Jahangir complains about his rebellious prince, “About which of my afflictions should I write? In my grief and weakness, and with such warm weather, which is extremely debilitating to my constitution, is it really necessary for me to get on a horse and gallop in this condition after such a villainous (na khalafi) son?"519

And clearly the Mughal ateke had by now begun to identify with his prince more often than had been the case among Timur's immediate successors. Khurram was joined in his revolt by his ateke, the Khan Khanan, about whom Jahangir laments, "If amirs like the Khan Khanan, who had been singled out for the exalted post of ataliq could dishonor himself at the age of seventy with such rebellious insolence and infidelity (bagi u kafir),

\footnotetext{
${ }^{516}$ Jahangirnama, p.147. Thackston, tr., p. 155. Baba was commonly used by the Mughals in India as an affectionate nickname, meaning baby or child, although its Persian meaning is grandfather or father. Note, also, the tellingly childish and diminutive nickname used by the emperor in referring to his twenty-two year old son in a letter to a third party.

${ }^{517}$ Ibid., p. 403.
} 
what complaint could one have of others? It was as though insurgence and ingratitude were innate components of his nature."520

Khurram's insurgency was unsuccessful, and he was forced to beg for pardon and send his eldest sons, Dara Shikuh and Aurangzeb, to live at his father's court as surety, but on the death of Jahangir he rushed to the capital and was able to overthrow his brothers and the son of Khusraw to become the new emperor, Shah Jahan. In a dramatic act of innovation within the Mughal succession traditions, in what seems to have been recognition of the personal threat posed by the Timurid-Mughal principle of tanistry, Shah Jahan had all other male members of his immediate family, a total of five princes, murdered within twenty-four days after his accession, "for the exigencies of the affairs of state." 521 He did not, however, threaten any of his own sons. For the first time in the history of the Timurid line, attempting to secure his reign against the threat of shared sovereignty, a newly enthroned Mughal ruler had even dependent and powerless male relatives, put to death, "executing all those in whose veins flowed the royal blood."522

Although Shah Jahan had been married and assigned his first rank at age fifteen, along with the income producing territory of Hissar Firuza, which had been the jagir of every previous Mughal emperor and a clear indication that he was the heir- apparent, ${ }^{523}$ he had been kept at court until age twenty- one or two. While a few of his sons served as

\footnotetext{
518 Ibid., p. 395.

${ }^{519}$ Ibid., p. 403. (nā khalafi $=$ degenerate, wicked, dastardly)

${ }^{520}$ Ibid.,p. 404.

${ }^{521}$ Inayat Khan, Shah Jahan Nama, p.14. "On royal command," the new emperor's brother, Shahryar, and nephews Bulaqi (Dawar Bakhsh), son of the emperor's deceased brother Khusraw, another brother, Gurshasp, along with Danyal's sons Tahmuras and Hushang, were put to death on February 2, 1628, four days after the khutba was read in Shah Jahan's name in Lahore.

${ }^{522}$ Ram Prasad Khosla, Mughal Kingship, p. 102.
} 
military commanders in their young adulthood, their first governorships were usually not assigned until much later. Aurangzeb, a military paragon, was sent to lead armies in the Deccan at age seventeen, but Dara Shikuh, the favorite, remained at court until he was nearly thirty. Murad Baksh was twenty-nine when he emerged from court to represent his father in Kabul, and Shah Shuja was seventeen when he was deputed as a military leader to the Deccan in 1633.

Shah Jahan, like Akbar and Jahangir, continually recalled his sons to court and rewarded their compulsory filial attentions with increased incomes and regular reassignments. For example, his youngest son, Murad Baksh, was assigned to Kabul during his father's fourteenth regnal year, in March 1641. One year later he was recalled and sent to Kangra to lead a military expedition. After a brief but successful campaign, Murad Baksh was recalled to court and then sent to Qandahar to support Dara Shikuh's military expedition. He was recalled in July of the same year and married. He was then assigned the governorship of Multan but recalled a year and a half later when his father fell ill in his seventeenth regnal year. In June of 1644 he was returned to Multan for another year, after which he was recalled and appointed to take part in the Mughal conquest of Balkh and Badakhshan. He was successful but resisted remaining in Balkh; his companions claimed to be "dreading the hardship of a winter in that climate." 524 Returning home without permission, he was stripped of his mansab (title) and jagirs (income- producing properties) but they were reinstated within a few months and assigned the governorship of Kashmir. One year later he was recalled to court and reassigned to the Deccan. A year after that, in his father's twenty- third regnal year, Murad

\footnotetext{
${ }^{523}$ Inayat Khan, Shah Jahan Nama, p. 119.
} 
Baksh was assigned to Kabul. Just over a year later, he was appointed to Malwa and a year and a half later, in March 1654, he was recalled and then sent on to Gujarat, where he was residing at the outbreak of the wars of the Shah Jahani succession. In all, Murad Baksh had been recalled and reassigned by his imperial father a total of eleven times in fourteen years. ${ }^{525}$

\section{Brothers at War}

The most famous of all Mughal succession wars was that which brought down a ruling emperor, Shah Jahan. When Shah Jahan fell ill in 1657, Shah Shuja was governor of Bengal, Murad Baksh was in Gujarat, Aurangzeb was leading military campaigns in the Deccan and Dara Shikuh was in Shahjahanabad, outside of Delhi, at his father's side. The sources indicate a clear preference for Dara Shikuh on the part of the emperor, for "when his other sons departed to their respective governments, the Emperor from excessive love and partiality, would not allow Dara Shikuh to go away from him.",526 Even when he was appointed provincial governor of Allahabad and the Punjab, Dara Shikuh remained at his father's side, sending his agents to rule his newly acquired territories in his stead. ${ }^{527}$ His military record was not exemplary. ${ }^{528}$ As heir apparent, Dara Shikuh was allowed to take on some of the duties of the reputedly ailing emperor, but his assumption of imperial power and attempts to prevent his brothers from communicating with their agents at court gave rise to rumors of the emperor's death.

\footnotetext{
${ }^{524}$ What would Babur, whose men complained of the heat in India, have thought!! Ibid., 356. ${ }^{525}$ Ibid.

${ }^{526}$ Muhammad Salih Kambu, Amal-i Salih, E\&D, VII, p. 128.

${ }^{527}$ Dara Shikuh, Majma' al-Bahrain, p. 3.

${ }^{528}$ Ibid.
} 
Later chroniclers accuse an "unworthy and frivolous" ${ }^{\text {"529 }}$ Dara Shikuh of encouraging a fraternal confrontation, claiming he conspired against his brothers, "interfered in the affairs of State, and induced His Majesty to do many unwise things that tended to create disturbances. ${ } 530$

Whether they rose up spontaneously at hearing rumors of their father's illness, or were compelled to rebel to protect interests threatened by their brother, the princes Shah Shuja and Murad Baksh, in their provincial capitals, each immediately declared himself emperor, appropriating the contents of his provincial treasury, issuing coins and having the khutba read in his name. ${ }^{531}$ Having been kept at military service most of their adult lives, these Mughal princes were skilled military strategists, and the family tradition of succession war had certainly encouraged each to prepare for his own turn. Yet while artfully complaining of Dara Shikuh's high-handedness, Aurangzeb, serving as a general in the Deccan, evinced a lack of interest in his father's throne, claiming instead to be drawn to the life of a holy man. Writing to his brother, Murad Baksh, Aurangzeb claimed, "I have not the slightest liking for or wish to take any part in the government of this deceitful and unstable world; my only desire is that I may make a pilgrimage to the temple of God." ${ }^{532}$ His actions belied claims to a desire for retirement, however, as he had already begun to prepare for war. "To carry out his aims, Aurangzeb had set himself to win over to his side the great nobles of the State, some of whom he had made his own, and that he was endeavoring to effect his object by secret communications before his designs had become public. The money he had received in tribute from Kutbul Mulk [as

\footnotetext{
${ }^{529}$ Muhammad Kazim, Alamgir Nama, E\&D, VII, p. 178.

${ }^{530}$ Salih Kambu, Amal-i Salih, E\&D, VII, p. 129.

${ }^{531}$ Inayat Khan, Shah Jahan Nama, p. 545.
} 
leader of the victorious Mughal forces in the Deccan] he had spent without permission in the raising of forces, and it would not be long before he would cast off his obedience and commence a war. ${ }^{533}$ Claiming only to be interested in putting his brother Murad Baksh on the throne, Aurangzeb combined their armies and marched on Delhi. ${ }^{534}$ Shah Shuja was routed early, and the carefully contrived strategic alliance between Aurangzeb and Murad Baksh was too powerful for the imperial armies. Defeating the forces of Dara Shikuh, Aurangzeb occupied Delhi and Agra, imprisoned his father, and forced him to abdicate in Aurangzeb's favor.

In addition to a general desire for personal sovereignty and the lifelong expectation of an eventual succession war, there is some suggestion that Shah Jahan's employment of a near Ottoman- style fratricide at the time of his own accession encouraged the four brothers in their murderous competition for the throne. An observer wrote, "Not only was the crown to be gained by victory alone, but in the case of defeat life was certain to be forfeited. There was now no choice between a kingdom and death; as Chah- Jehan had ascended the throne by embrueing (sic.) his hands in the blood of his own brothers, so the unsuccessful candidates on the present occasion were sure to be sacrificed to the jealousy of the conqueror."${ }^{, 535}$

Yet the fear of execution by whichever brother gained the throne might have been allayed by a remarkable gesture made by the weakened Shah Jahan. With Dara Shikuh still in the field, Shah Jahan made his sons an offer worthy of a Timurid ruler, proposing to partition the empire into classic Turco- Mongol appanages, shared among the four

\footnotetext{
${ }^{532}$ Khafi Khan, Muntakhab'ul Lubab, E\&D, VII, p. 217.

${ }^{533}$ Saih Kambu, Amal Salih, E\&D, VII, p. 129.

${ }^{534}$ Khafi Khan, Munakhab'ul Lubab, E\&D, VII, p. 217-18.
} 
princes: Dara Shikuh would receive the Punjab, Murad Baksh would take Gujarat, Shah Shuja would have Bengal, and the remainder would be assigned to the clear victor, Aurangzeb, who would henceforth receive the title of Shah Buland Iqbal (King of Supreme Good Fortune) which had been formerly attached to their father's favorite, Dara Shikuh. ${ }^{536}$ This attempt by Shah Jahan to revive ancient Central Asian appanage practices in order to defuse a succession conflict was unsuccessful. Perhaps doubting his father's sincerity, and justifiably confident that the entire empire lay within his grasp, Aurangzeb continued to pursue his rivals.

In an interesting rejection of his father's dramatic accessional murder of his brothers and nephews, Aurangzeb in his own turn, requested and received formal legal sanction for the execution of his last surviving rivals. It was more than a year after the war's commencement and six months after Aurangzeb's coronation that Dara Shikuh was captured and publicly humiliated. Tried in court as a heretic and danger to the state, on the basis of his attempts to identify and articulate a spiritual union between Hinduism and Islam, Dara Shikuh was executed. ${ }^{537}$ Obtaining a legal ruling to support yet another fratricide, Aurangzeb handed his former ally, Murad Baksh, over to enemies, "who had a charge against him for the murder of their father," and who were allowed to demand his assassination. Murad Baksh remained philosophical, saying "If the Emperor [Aurangzeb] will accept my pledges and save my life, no harm will come to his throne; but if he is resolved to take my life... he has the power and can do what he likes. ${ }^{, 538}$ Later

\footnotetext{
${ }^{535}$ Francois Bernier, Travels, p. 25.

${ }^{536}$ Inayat Khan, Shah Jahan Nama, p. 554.

${ }^{537}$ For a discussion of the "heresy of Dara Shikuh," see Muhammad Kazim, Alamgir Nama, E\&D, VII, p. 179, and Khafi Khan, Muntakhab'ul Lubab, E\&D, VII, p. 214.

${ }^{538}$ Salih Kambu, Amal-i Salih, E\&D, VII, p. 132
} 
chroniclers reflected on this "simple mindedness" of Murad Baksh, explaining that his murder was required on the basis of the classic verse by Sa'di, oft quoted by their dynastic founder Babur, which declared that two kings cannot be contained in a single kingdom. ${ }^{539}$ They ignored Babur's heartfelt injunctions for fraternal forgiveness.

Aurangzeb left unharmed, however, those of Dara Shikuh's sons, grandsons and daughters who had not participated in the succession war. As we have seen, he treated Dara's favorite sister, and active supporter throughout the succession war, Jahanara, with respect and admiration for the remainder of her life. ${ }^{540}$ Not only to justify the murder of his brothers and nephew, but to legitimate his outrageous seizure of power from the living emperor, Shah Jahan, Aurangzeb enlisted the assistance of the religious legal community. When the Mughal's chief qadi (judge) refused to read the khutba in his name, Aurangzeb convinced the scholar, Shaykh Abd al-Wahhab (d. 1650), to insist on public acknowledgement of the legality of his claim to the throne..$^{541}$

Shortly thereafter, Dara Shikuh's son, Suleiman Shikuh, was captured and imprisoned at the fort of Gwalior. A proven threat to his uncle, he was murdered without the sanction of legal proceedings like those which had preceded his father's execution. On the orders of his emperor- uncle, Suleiman Shikuh was buried next to his uncle, Murad Baksh. ${ }^{542}$ Although skirmishes had continued until all of Aurangzeb's rivals had been found and executed, Aurangzeb resolved one of the Mughal's lengthiest and most destructive succession conflicts, concluding with the confinement of his father and the

\footnotetext{
${ }^{539}$ Khafi Khan, Muntakhab'ul Lubab, E\&D, VII, p. 228.

${ }^{540}$ See this study, chapter three.

${ }^{541}$ Alan M. Guenther, "Hanafi Figh in Mughal India: The Fatawa-i Alamgiri," India's Islamic Traditions, 711- 1750, Richard M. Eaton, ed., New Delhi: Oxford University Press, 2003, p. 211.

${ }^{542}$ Salih Kambu, Amal-i Salih, E\&D, VII, p. 131.
} 
destruction of those brothers and nephews deemed dangerous, nearly all legally sanctioned.

In the long years of his own reign, Aurangzeb's relationship with his own sons seems to have been tortured and fearful, driven by the emperor's fear that he would suffer from his sons the fate he had meted out to his father. The mistrust which developed between the emperors and their rival sons led a bitter Aurangzeb to advise his successors to, "Never trust your sons or treat them during your lifetime in intimate manner, because if the emperor Shah Jahan had not treated Dara Shukoh in this manner his affairs would not have come to such a sorry pass.",543

Over time, only one of his five sons escaped a lengthy prison sentences meted out for real or imagined insurrection. His eldest son, Muhammad Sultan, had, during the war of succession, joined his uncle Shah Shuja in opposition to his father and although he soon returned to the fold, for this betrayal he would be imprisoned by his newly enthroned father for the rest of his life. ${ }^{544}$ Aurangzeb's second son, and eventual successor, Bahadur Shah, was found to be corresponding with the enemy and was imprisoned along with his sons for eight years until his release in 1695. His courage never returned however, and his father "taunted him with cowardice, though the prince was already a grandfather." ${ }^{545}$ Yet with all this, the only open revolt against Aurangzeb came from his fourth son, Akbar, who, while on military duty in Rajasthan, proclaimed himself emperor. He was quickly routed by the imperial forces and forced to flee to Iran. Aurangzeb never forgot the threat this rebellious son represented, and on finally hearing

\footnotetext{
${ }^{543}$ Hamid al- Din Bahadur, Ahkam-i Alamgiri, Sir Jadunath Sarkar, tr. as Anecdotes of Aurangzeb, Calcutta: M.C. Sarkar and Sons, 1927.

${ }^{544}$ Sir Jadunath Sarkar, History of Aurangzib, London: Orient Longman Limited, 1973, III, p. 4.
} 
of Akbar's death years later, he expressed relief, exclaiming, "The great troubler of the peace of India is gone. ${ }^{, 546}$

On his deathbed Aurangzeb seems to have reflected on a long and bitter existence, writing to his sons, "I have a dread for my salvation, and with what torments I may be punished. Though I have strong reliance on the mercies and bounties of God, yet regarding my actions, fear will not quit me;",547 and, "I have committed numerous crimes, and know not with what punishments I may be seized." ${ }^{548}$ Deeply fearful of the war of succession which he rightly suspected would follow his death, Aurangzeb, like his own father Shah Jahan, attempted to implement the Timurid solution, leaving a will which would partition the empire into appanages, divided amongst his three surviving sons. His divisions were generous: Kam Baksh would receive Bijapur and Haydarabad; Azam Shah (the later Emperor Bahadur Shah) would take Agra and the provinces of Deccan, Malwa, Ahmadabad, and Gujarat; while Muhammad Muazzam would receive Delhi, Kabul, and all other territories. Aurangzeb's attempt to return to the classic princely appanages of his Mongol- Timurid ancestors was as unsuccessful as his father's had been. Azam Shah urged his younger brothers to accept the terms, even offering to give them the additional territories of Gujarat and Ajmer, but the two brothers refused the offer. Both were killed in the succession war which followed. ${ }^{549}$

\footnotetext{
${ }^{545}$ Ibid., p. 30.

${ }_{546}^{546}$ Ibid., p. 34.

${ }^{547}$ Iradat Khan, Tarikh, (Letter from Aurangzeb to his grandson Shah Azam Shah), E\&D, VII, p. 563.

${ }_{548}^{548}$ Ibid. (Letter from Aurangzeb to his son, Kam Bakhsh), p. 65.

${ }^{549}$ Khosla, Mughal Kingship, pp. 111- 113.
} 


\section{How Succession Wars Served the Dynasty: Benefits of Turco-Mongol Tradition}

It is possible to identify in Islamic Central Asia the origins of notions of rivalry, loyalty and political entitlement which were embodied in Mughal imperial traditions and which defined Mughal acceptance of sovereignty and political viability. Other TurcoMongolian empires, notably the Ottomans, Uzbeks, and Safavids, initially used similar succession practices (using the tanistry principle linked, as in the Mughal case, with the assignment of princely appanages), but they eventually created alternative systems which successfully contained succession rivalries within the palace, thereby avoiding expensive and destructive wars. Yet throughout the period of greatest Mughal prosperity and strength the absence of a fixed law of inheritance guaranteed the outbreak of a war of succession on the death or deposition of each monarch, and although these wars are described in the chronicles as destructive, ranging across the land, laying waste and destroying property, the Mughals never successfully constructed an alternative, less traumatic method of ordering succession. An examination of the roots of this tradition and its links to Mughal ideas of political legitimacy explains not only how the Mughals created their system of succession but also why they displayed such unwavering loyalty to a principle which has most often been viewed as inefficient and often wantonly destructive.

That the origins of their succession system can be directly traced to the practices of their Mongol- Timurid predecessors is a fact the Mughals themselves were quick to acknowledge, and the appanage system derived from Central Asian tradition surely played a role in inspiring and encouraging the bloody Mughal succession wars that occurred with almost every generation. Inexplicably, princely appanages have been 
consistently ignored in contemporary studies of Mughal succession conflicts, but the degree to which these positions, even modified to discourage childhood assignments, offered Mughal princes autonomous bases of power-- military, economic, and political -must be explored as it relates to their ability to wage war and wield influence. The benefits to the dynasty were obvious, however, in that more often than not, a qualified candidate for king of an actively expansionist empire emerged from the fracas already in control of a successful ruling bureaucracy, military force, treasury, administrative system, and, perhaps most importantly, networks of influence and patronage that extended across the subcontinent, supporting and affirming his rule, drawing centralizing influences outward to the margins of empire. Even with sixteenth-century modifications of princely governorships and increased imperial control over the actions of the royal princes, Mughal wars of succession were allowed to rage unabated.

A further benefit accrued to the Mughals from their loyalty to Turco- Mongol tradition. While in Central Asia the tradition of tanistry had often "resulted in the regular re-subjugation and reintegration of clans, affirming their social coherence among the otherwise centrifugal forces of steppe society," hundreds of years later, in sedentary imperial India, tanistry continued to allow those in opposition to the center of power to remain within the orbit of the ruling family. Through alliance with rival princes, leaders of viable factions were given a safe outlet for the expression of public opposition to their fathers and brothers. Several scholars have noted that princely factions were not defined by religion or race; instead, alliances could be, and often were, based on general 
dissatisfaction with the ruling center. ${ }^{550}$ In his own rebellious youth, one of Jahangir's alliances had been with those who had formerly followed Akbar's rebellious brother, Mirza Hakim, in Kabul. Lala Beg Kabuli, Khwaja Dost Muhammad and Zamana Beg all joined Jahangir's service and rose to power when he became emperor. ${ }^{551}$ Having first allied with them as a mutinous prince, Jahangir brought a remarkable coalition of "formerly marginal Afghans, Shaykhzadas, Mirzas, Kashmiris and Pahari and Bundela Rajputs" into the mainstream imperial establishment. ${ }^{552}$

As focal points of political opposition to their father and to each other, rival princes offered viable alternative loci of power to which the loyalty of alienated, disenfranchised, dissatisfied and recalcitrant elites could be attached. For example, Mughal courtiers and allied chieftains had justifiable concerns regarding the ability to rule of emperors Humayun and Jahangir — both were known drug addicts. During their reigns, rivals from within the royal family allowed the opposition to coalesce around alternative Mughal power centers; the threat of deposition was thereby expressed relatively harmlessly toward individuals rather than against the dynasty as a whole. Retaining Turco- Mongol traditions of universal legitimacy and princely power offered India's imperial dynasty a critical safety valve which effectively positioned the royal family above the individual, protecting and sustaining their power as a group. As in Timurid Mawarannahr until the arrival of the foreign power of the Uzbeks, individual rulers faced constant rivalries within the family but the skirmishes were internal scuffles

\footnotetext{
${ }^{550}$ For example, Faruqui, "Princes and Power," and Satish Chandra, Parties and Politics at the Mughal Court, 1707- 1740, New Delhi: Oxford University Press, first pub. 1959, $4^{\text {th }}$ ed., 2002-3.

${ }_{552}^{551}$ Faruqui,"Princes and Power," p. 52.

${ }^{552}$ Ibid., p. 128.
} 
that remained, however fierce and bloody, comfortably under the greater dynastic umbrella.

The Mughals were able to create a successful and centralized monarchy which faced remarkably little in the way of serious external threats. The subject population and the aristocracy seem to have accepted, with few signs of displeasure, this imperial lineage: for well over two hundred years the most serious threat to Mughal sovereignty lay in the regular bitter and bloody conflicts which sprang from within the royal family itself. Yet while the succession wars exposed the authority and legitimacy of each succeeding emperor to very public scrutiny at the time of his accession, there seems to have been no subsequent crises of legitimacy for the new monarch, for yet another survival of the Central Asian past asserted that individual legitimacy was framed not only in dynastic claims but also in terms of divine sanction. Political legitimacy for Chingiz Khan had included the conviction that "God had designated him the sole legitimate ruler of the world,", 553 and biographers of Timur wrote, "Whenever God Almighty exalts any person to the throne of sovereignty, he confers on him a special dignity and wisdom, by means of which he renders mankind obedient to him." 554 By Akbar's time this heavenly sanction had evolved into an assertion of a "divinely illumined right of the Emperor to rule mortals with lesser qualities." ${ }^{, 555}$ While any and all Timurid royal sons had the right to claim political sovereignty, those successfully enthroned defended their victories with claims of heavenly support. Their very success served as evidence that their claim to power was legitimate.

\footnotetext{
${ }^{553}$ Streusand, Formation of the Mughal Empire, p. 29.

${ }_{554}^{55}$ Khosla, Mughal Kingship, p. 9.

${ }^{555}$ Richards, "The Formulation of Imperial Authority," p. 260.
} 
Jahangir confirmed this in his commentary regarding the unsuccessful claims of his son Khusraw. "They [the followers of Khusraw] were, of course, unaware of the fact that the rule of empire and royal command (umur-i sultanat u jahanbani umari) are not something which can be carried out by a couple of intellectually deficient (naqis 'aqli) individuals. Whom does the All- Giving Creator consider worthy (shayista) of this glorious and noble authority? And upon whose shoulders has he draped this robe of honor (khil'at)?" ${ }^{, 56}$ The Mughal wars of succession, then, became an opportunity to illustrate the preference of the deity by establishing the identity of the next monarch. A chronicler explained the success of Aurangzeb in defeating his brother, the favorite and chosen successor, Dara Shikuh as a heavenly intervention: "The charge [of rule] was accordingly undertaken by the prince [Dara Shikuh], but Providence had determined otherwise. The country was destined to be ruled by a more just and better prince, and every circumstance which occurred in those days combined to assist him in obtaining the throne. ${ }^{.557}$ In a letter to his father, Aurangzeb described a similar justification. "It is clear to Your Majesty," he wrote, "that God Almighty bestows his trusts on one who discharges the duty of cherishing his subjects and protecting the people. It is manifest and clear to wise men that a wolf is not fit for a shepherd." ${ }^{558}$

Indirect as the succession may have been, the legitimacy of the dynastic pattern would not be questioned. Not only did princely succession wars result in the reintegration of opposition groups, but they also offered Timurid- Mughal princes an

\footnotetext{
${ }^{556}$ Jahangirnama, p. 30. Here Jahangir uses the term khil'at in order to describe what is in effect a robe of office (as per Thackston tr., p. 48). By using the word for the robes of honor that were conferred upon dignitaries and nobles by the Timurid- Mughal monarchs, he evokes the imagery of a powerful ruler (god) rewarding an honored subject (himself, as king).

${ }^{557}$ Mufazzal Khan, Tarikh-i Mufazzal, E\&D, VII, p. 143.
} 
opportunity to publicly establish their standing in the eyes of providence; the victorious successor to the Mughal throne proved God's sanction by the very fact of his victory. While the uncertainty of succession proved to be periodically divisive and destructive, it remained bound to the Timurid tradition of universal sovereignty and supported by divine sanction, whereby individual and dynastic claims to rule "rested on an ultimate legitimacy far surpassing the accidents of conquest, coup, or succession." ${ }^{, 559}$ As a critical link to their Timurid steppe heritage, the principle of tanistry remained central to Mughal understanding of dynastic legitimacy and was never substantially modified or reformed. Although it provoked devastating wars among brothers, and could eventually result in an indirect dynastic line, for the hundreds of years of Mughal rule in India, Turco-Mongol tradition defined individual rights to sovereignty and political legitimacy.

\footnotetext{
${ }^{558}$ Khafi Khan, Muntakhab'ul Lubab, E\&D, VII, p. 253.

${ }^{559}$ Richards, "Formulation of Imperial Authority," p. 260. One of the chief concerns of the nineteenthcentury Mughal dynasty was the attempt by the British to impose a rule of primogeniture on the royal family. See William Dalrymple, The Last Mughal, New York: Alfred A. Knopf, 2006.
} 


\section{CHAPTER 6}

ETHICS AND MORALITY

A further direct inheritance of the Mughals from their Central Asian ancestors was a body of religious and ethical understandings, a Timurid stew of Perso-Islamic and Chingizid systems of morality, ethics and law, which came to be carefully maintained on the subcontinent. Although the two sets of traditions each claimed universal applications, Timur had managed to successfully merge them into a legitimizing ideology that supported and sustained not only his own imperial pretensions but also those of his dynasty. ${ }^{560}$ In examining the ethical and moral understandings of the Timurid-Mughals, we can employ as a framework a particular body of literature which offered the dynasty the most clearly articulated explanation and defense of its ethical personality: alMarghinani's Hedaya; Nasir al-Din Tusi's Akhlaqi Norms; the medieval Persian poetry of Rumi, Hafiz and Sa ${ }^{\circ}$ i; and the perhaps imagined but no less powerful or influential Yasa, or law code, of Chingiz Khan. This collection of works speaks with a high degree of mutuality and synergy, describing a very particular understanding of spirituality, human relations and kingship; each represents a particular component of the TimuridMughal personal and dynastic ethical complex and all came to be mobilized in defense of the evolving imperial performance.

\footnotetext{
${ }^{560}$ See Manz, The Rise and Rule of Tamerlane, and idem., "Temur and the Problem of a Conqueror's Legacy," Journal of the Royal Asiatic Society, 3/8/1 (1998), pp. 21- 41.
} 
Islamic Identity and the Timurid-Mughals

Although Timur has been regularly accused, by his own contemporaries as well as modern scholars, of a lack of sincerity in his religious loyalties, there is no reason to suppose that his descendants were only superficially loyal to Islam. ${ }^{561}$ Certainly it is true that the Timurid-Mughals demonstrated a high degree of religious pragmatism and flexibility from the time of the dynasty's origins in Mawarannahr-- a remarkable degree of tolerance and acceptance of alternative faiths, even occasional fluidity in their individual interpretations of religious identity-- yet their fundamental dynastic loyalty for Islam was sustained until their imperial demise in the mid-nineteenth century. Apart from a few infamous heterodox gestures in the later years of Akbar, who continued to insist on his own Muslim identity even while engaging in sun worship at dawn, the Mughals remained closely tied to their religion. This loyalty was maintained, however, within the context of their ancestral Timurid religious model.

Timur and his descendants, along with most Central Asian Turks, were Sunni Muslims of the Hanafi mazhab who relied heavily on, among other less well known Central Asian works of fiqh scholarship, Ali ibn Abi Bakr al-Marghinani’s (d. 1196) classic twelfth-century legal treatise, the Hedaya ${ }^{562}$ Affirming Timur's support of Marghinani’s legal scholarship, Marghinani’s son, Mawlana Abdul Malik, served Timur as a judge in the law court of Samarqand. ${ }^{563}$ Although the Hedaya was a standard and

\footnotetext{
${ }^{561}$ For example, see Ibn Arabshah, Tamerlane, p. 298-9.

${ }^{562}$ Ali ibn Abi Bakr al-Marghinani, The Hedaya or Guide: A Commentary on the Mussulman Laws, Charles Hamilton, tr., $2^{\text {nd }}$ ed. (London, 1870; reprint Lahore: Premier Book House, 1963).

${ }^{563} \mathrm{Ibn}$ Arabshah, Tamerlane, p. 312. Arabshah adds that Mawlana Abdul Malik could "at one time train the studious, follow a game of chess and dice, and compose a poem."
} 
popular study of figh and had been applied, along with local Muslim collections of authoritative rulings, on the subcontinent through the years of the Delhi Sultans, its central importance in India was confirmed and maintained by continued Mughal patronage.

The Hedaya was particularly influential in the evolving presentation of Hanafi fiqh in Mughal India and served as the foundation for the later Fatawa-i Alamgiri, commissioned by the emperor Aurangzeb (r. 1658-1707) to serve as the ultimate compendium of Mughal legal understanding. At four times the length of the Hedaya, the Fatawa-i Alamgiri was in fact an extension of the former; retaining nearly unchanged the original format and adding those legal arguments which had developed authoritative status in India, it presented "a comprehensive review of Hanafi fiq $h$ " on the subcontinent. ${ }^{564}$ However it was to the original Hedaya that British officials turned to supply the standard legal authority in the Muslim courts of the East India Company, where the preferred figh scholarship of the Timurids remained the basis of Islamic law on the Indian subcontinent throughout the colonial period. ${ }^{565}$ Meanwhile, the Fatawa-i Alamgiri came to be known as the Fatawa-i Hindiyya, acknowledged as a crucial Hanafi authority among jurists across the Muslim world, including those of the Ottoman Empire. In a not unusual reversal of intellectual and religious influence, the legal work was imported back to the place of its origins, Central Asia. ${ }^{566}$

Like Timur and his immediate successors in Transoxiana, the Mughal emperors displayed varying degrees of religious nonchalance yet made regular public gestures

\footnotetext{
${ }^{564}$ Alan M. Guenther, "Hanafi Fiqh in Mughal India," p. 224.

${ }^{565}$ Ibid., p. 210.

${ }^{566}$ Ibid., p. 217.
} 
which were intended to affirm their Muslim credentials. The founder of the Indian empire, Babur, whose displays of religious pragmatism have been well documented, was quick to publicly align himself with the ghazi, holy warrior, ethos when it became useful to do so. Leading his troops against a larger and better equipped army of Hindus, Babur was quick to call on God's help in a battle against the non- believers, kafirs, in order to encourage his troops. "Those who die," he told them, "are martyrs and those who kill are holy warriors (olgan, shahid; olturgan, gazi)." 567 The cynicism of Babur's call to religion is apparent, perhaps even to him. "Beg and noker, great and small alike, all willingly took the Qurans in their hands, and swore oaths to this effect. It was a really good plan (tavur tadbiri idi) and it had a good [propagandistic] effect on friend and foe (yavuqtin yiraqtin, dust u dushman, kurkali eshitkali yahkshi buldu)." ${ }^{, 568}$ In the aftermath of victory, Babur composed a ruba $i$ to celebrate his ghazi status, although the verse has been described as "more like a ritualistic observance or an ex post facto religious legitimation than a cry of religious triumph."

I am become a desert wanderer for Islam, Having joined battle with infidels and Hindus I readied myself to become a martyr, God be thanked I am become a ghazi.

Islam ichin avara-i yazi buldum, Kuffar $u$ hind harbsazi buldum Jazm aylab idim uzni shahid olmaqqa, Amminna' lillahi ki gazi buldum. ${ }^{570}$

While his pleasure at surviving as ghazi rather than dying a martyr, shahid, is understandable, it is only in the few pages dwelling on this battle and his victory that

\footnotetext{
567 Baburnama, p. 507.

${ }^{568}$ Ibid. Thackston, tr., p. 691.

${ }^{569}$ Dale, Garden, p. 351.
} 
Babur conjures overt images of the Quran, and only here, in the aftermath of the battle against Rana Sanga, does he evoke the imagery of the ghazi. ${ }^{571}$ Shortly after the battle of Khanua, having achieved resounding success, he began welcoming the military contributions of Hindus into his Indian army of conquest and seems to have again turned his thoughts to the conquest of territory, rather than the destruction of kuffar $u$ hind.

The Mughals periodically articulated imperial loyalty to the shari $a$, appointed and maintained salaried sadrs and qadis, and generously sustained a class of learned Muslim scholars in India through the support of land and cash grants. ${ }^{572}$ Not only did individual emperors send beneficent donations to the Holy Cities of Mecca and Medina, but they periodically funded the annual hajj (pilgrimage) and regularly expressed concern for the safety of pilgrims en route. Yet for all their dramatic public gestures illustrating dynastic and personal allegiance to Islam and confirming traditional Sunni Muslim religious loyalties, like Babur, generations of Mughal kings continued to balance that particular ethical symbiosis which had evolved in the royal courts of Chingizid- Timurid Central Asia.

Sufi Allegiances: The Naqshbandi, the Chishti, and the Royal Cult

Establishing close ties with a variety of Central Asian Sufi orders offered the Timurid dynasty the necessary public affirmation of religious identity without forcing them into a close association with a strict or narrow interpretation of Islam. As we have

\footnotetext{
${ }^{570}$ Baburnama, p. 521. Dale, Garden, tr., p. 351.

${ }^{571}$ In his description of this one battle Babur quotes verses of the Quran a remarkable total of nine times.

572 Muzaffar Alam, "State Building Under the Mughals," L'Heritage Timouride, Iran-Asie Central-Inde, XVe-XViiie Siecles, Les Cahiers d'Asie Centrale, Maria Szuppe, ed., Tachkent- Aix-en-Provence, 1997, p. 124.
} 
already pointed out, Timur most successfully affirmed his religious credentials through his generous patronage of Sufi orders, ${ }^{573}$ yet reports of Timur's personal religious insouciance would suggest that even his patronage of the very popular Naqshbandis was part of a cynical and deliberate effort to access the heightened religious legitimation that support by this conservative Sunni order would offer him.

In stark contrast to Timur's personal religious liberality, the Naqshbandi religious expression aligned closely with the example of the Prophet, and the order came to be characterized by a "particular sobriety." 574 Their silent zikr (repetition of the name of God) and private, near secret, worship, combined with enthusiastic participation in public affairs, offered members of the order a degree of freedom which allowed them to amass enormous wealth and power in Timurid Central Asia. It was their pragmatic blend of the mystical with the economic and political, constituting "a great synthesis of Sunni Islam," which seems to have been the key identifying quality of the Naqshbandis. ${ }^{575}$ In part because of their insistence on direct involvement in local Timurid politics and their close relationships with various Timurid rulers, the Naqshbandis became the most influential and important Sufi order in Central Asia. ${ }^{576}$ Timurid reliance on these legitimizing relationships with Naqshbandi leaders continued well into their Indian period.

The Mughals were careful to nurture the important historical Timurid political and social alliance with the Naqshbandiyyah. Apart from personal spiritual

\footnotetext{
${ }^{573}$ See this study, chapter two.

574 Jürgen Paul, Doctrine and Organization: The Khwajagan/ Naqshbandiya in the first generation after Baha'uddin, ANOR 1 (1998), p. 47. Paul's study of the practices and doctrine of the Khwajagan/ Naqshbandi gives a clear sense of the growing pragmatism of the order and gradual rejection of ecstatic worship amongst Naqshbandis in the transitional early modern period. It is important to note that not all Naqshbandiyyah conformed to the silent zikr and rejection of ecstatic worship, though this was the norm among the Ahrari Naqshbandis who became so closely tied to the Timurids and Mughals.

${ }^{575}$ Ibid.
} 
considerations, Mughal patronage of the Naqshbandi order may have increased Mughal religious and political legitimacy in the eyes of their subjects, critical in the context of their new imperial territories. With Babur's increased success, the relationship between the Timurid and Ahrari families grew closer and the powerful and influential Naqshbandis achieved the status of spiritual nobility, resulting in the establishment of "an informal aristocratic Naqshbandi lobby at the Mughal court. ${ }^{\text {577 }}$

Although personally affiliated most closely with the Shattariyya order of Sufis, ${ }^{578}$ Babur's son Humayun, in his own desperate period of imperial restoration, was accompanied by two Ahrari Naqshbandis, Khwaja Khwand and his son Khwaja Mu'in, in the role of "spiritual confidantes." $"$ "In what has been described as a "new phase of Timurid- Naqshbandi relations," the Ahrari Naqshbandis of Kabul, already economic and political allies, became entwined in Timurid family affairs through a series of intermarriages with the Mughal dynasty; Khwaja Mu'in married Humayun's daughter, while a second daughter, Bakshi Banu Begim, married the grandson of Khwaja Khwand, Mirza Sharif al-Din, in 1560 or 1561 in Agra. ${ }^{580}$ During the reign of Akbar, another of Humayun's daughters, Fakhr al-Nisa Begim, was married to a Kabuli Ahrari known as Hasan Naqshbandi, who later allied himself with the rebellion of Akbar's half- brother, Mirza Muhammad Hakim, and was forced to flee Kabul for Balkh a year later. ${ }^{581}$ His

\footnotetext{
${ }^{576}$ Ibid., pp. 21- 25.

${ }^{577}$ Dale, "Legacy of the Timurids," p. 47.

${ }^{578}$ S.A.A. Rizvi, "Sixteenth Century Naqshbandi Leadership in India," Naqshbandis, Marc Gaborieau, Alexandre Popovic, Thierry Zarcone, eds., Istanbul: Isis Press, 1985/1990, p. 154. In the modern period, the Shattariyya (Satarijah) order has come to be closely associated with Southeast Asian Islam, particularly Sumatra and Java. See Azyumadri Azra, The Origins of Islamic Reformism in Southeast Asia, Honolulu: University of Hawai'i Press, 2004.

${ }^{579}$ Dale and Payind, p. 225.

${ }^{580}$ Ibid.

${ }^{581}$ Abu'l Fazl, AN, II, p. 409 and note 2. See also Dale and Payind, p. 225.
} 
son, Mirza Wali, who despite his father's disgrace had been welcomed with an imperial appointment at Akbar's court, later married the niece of the emperor Jahangir, Bulaqi Begim, daughter of his brother Danyal. ${ }^{582}$ Even throughout the religiously heterodox years in the later period of Akbar's reign, the Naqshbandi order maintained a large number of loyal adherents in the Mughal court and continued to import leadership from Transoxiana who duly received generous patronage and positions within the Mughal administration directly from the Mughal emperor. ${ }^{583}$ Khwaja Abd al-Azim, son of the Naqshbandi shaykh Khwaja Khwand, was a close ally of Akbar even in the years of the emperor's more extreme spiritual experimentation, and "helped suppress the rebellion of the disgruntled ulama." 584

The only suggestion of a rift between the Naqshbandi and Mughal families occurred during the reign of Jahangir, when the political/religious activities of two members of the Naqshbandi leadership came to the attention of the emperor. The first was Khwaja Khawand Mahmud (b. 1557-8), an immigrant from Central Asia, whose proselytizing zeal in the interests of orthodox Sunni Islam brought many at the royal court in Agra into the order, but complaints to the emperor of enthusiastic self- promotion led to his dismissal, first to his religious base at Srinagar in Kashmir, from where he was later exiled to Kabul. He was eventually allowed by Shah Jahan to return to Kashmir but

\footnotetext{
${ }^{582}$ Jahangirnama, p. 309. Also see Abu'l Fazl, AA, I, p. 323. Jahangir offers nothing but praise for the disgraced khwaja, describing him as combining "a noble lineage with personal worth."

${ }^{583}$ Rizvi, "Sixteenth Century," 154.

${ }^{584}$ Ibid., 155.
} 
even then, at the age of eighty, he was considered an active troublemaker and was finally permanently exiled to Lahore. ${ }^{585}$

Far more significantly, the Naqshbandi Shaykh Ahmad Sirhindi (d. 1624), known by the sobriquet Mujaddidi-i alf-i sani, Renewer of the Second Millennium, began a public campaign calling for a return to conservative Islamic values. Arguing against Mughal religious permissiveness, as illustrated by regular appointment of non- Muslim officials, ban on cow slaughter, permission to construct Hindu and Christian temples and refusal to impose the jizya, a Quranic poll-tax on non-Muslims, Sirhindi instigated a campaign of public opposition to imperial policy. Accounts of Sirhindi's battles against Mughal religious idiosyncrasies and innovations have been shown to be somewhat exaggerated, as has his degree of influence with Mughal rulers. ${ }^{586}$ Of the 534 Sirhindi letters collected in the Maktubat, only seventy were addressed to "servants of the empire," such as Shaykh Farid Bukhari, who offered financial support to Sirhindi's Indian khanaqah. One of the most important court officials associated with Sirhindi was Akbar's Abd al-Rahim Khan-i Khanan, who was most likely a murid of the Naqshbandi shaykh and was praised by Sirhindi for his service to the order. ${ }^{587}$ However, few Sirhindi letters address political policy concerns; most were requests for intervention on behalf of Sirhindi’s followers. ${ }^{588}$ Those letters which do illustrate an effort to impose Sirhindi's vision of an Islamic state on members of the Mughal court complain bitterly of Akbar's lack of interest in conservative, legalist Islam, demand the strict implementation of the

\footnotetext{
${ }^{585}$ Ibid., 156. Rizvi comments that even his tomb in Lahore was the source of trouble. Complaints were made that its ostentatious structure violated Naqshbandi aspirations to personal simplicity.

${ }^{586}$ See Johanan Friedmann, Shaykh Ahmad Sirhindi, An Outline of His Thought and a Study of His Image in the Eyes of Posterity, Montreal and London: McGill University Press, 1971, and Friedmann, "The Naqshbandi Reaction Reconsidered."
} 
shari'a, harangue against Hindu hegemony, and rejoice (prematurely, as the shaykh would learn) at the accession of Jahangir. In the absence of extant answers to these missives, however, it is not possible to affirm a high degree of Sirhindi influence at court. Throughout this period, rich gifts and lines of poetry were regularly exchanged ${ }^{589}$ between the Mughal court and the Transoxiana- based order, and the emperor Jahangir described himself as "among the devotees and a sincere servant" of the hereditary leader of the order in Transoxiana. ${ }^{590}$ When an important Naqshbandi sheikh, Khwaja Abdul Rahim, arrived as emissary from Transoxiana, Jahangir honored him by exempting him from korunush and taslim, the traditional performance of obeisance before the emperor. ${ }^{591}$ Jahangir's continued generous and affectionate attentions to the Naqshbandi leadership would seem to indicate that his eventual imprisonment of Sirhindi was not motivated by a rejection of his family's close alliance with the Naqshbandi order but rather because of his dislike of public criticism and well- founded fear of public disturbance.

In contrast to his stated intention to bring the Mughal dynasty back into the fold of orthodox Islam, Sirhindi was seen by the emperor as an arrogant religious imposter. Describing Sirhindi as a hypocrite (shaiyad), and his writings as "a war of nonsensical rhetoric" (janq-i muhimmilat) which would lead to infidelity and apostasy (kafir u ridda), Jahangir claimed that Sirhindi and his followers had spread a "snare of hypocrisy and subterfuge" (dam-i zarg u salus), peddled mysticism and hoodwinked a gullible

\footnotetext{
587 Johanan Friedmann, Shaykh Ahmad Sirhindi, p. 81.

588 Ibid., p. 79.

589 Jahangirnama, pp. 175-6.

590 Samarqandi, Conversations, p. 40.

591 Jahangirnama, p. 503.
} 
public. ${ }^{592}$ In punishment for what Jahangir described as the Shaykh's "arrogance"

(khudnama) and "idle talk" (bi sarfa gu), the emperor had Sirhindi imprisoned in the fort of Gwalior. ${ }^{593}$

A chastened Sirhindi was released after one year, remaining at court for some months in seeming amity with Jahangir, ${ }^{594}$ even the recipient of imperial alms in later years ${ }^{595}$ while the traditional social alliance between Naqshbandi and Timurid remained comfortably intact. ${ }^{596}$ Most Naqshbandi leaders continued to maintain good relations with the imperial court, as had Sirhindi's own teacher and preceptor, Khwaja Baq'i Billah (d. 1603). When Baq'i Billah, himself a spiritual descendant of Khwaja Ahrar, arrived from Kabul and set about quietly establishing a Naqshbandi khanaqah in Delhi he was patronized by Mughal officials, many of whom he initiated into the order, yet he made it a point to avoid interference in state policy. ${ }^{597}$ As for Khwaja Khwalan Mahmud, the Naqshbandi leader who had been exiled by Jahangir and Shah Jahan, he left behind a son, Khwaja Khawand Mu'in al- Din, who became a respected and influential religious leader in Mughal India, compiling religious- legal decisions (fatwas) into a study of fiqh entitled the Fatawa Naqshbandiyya, which was later used by Aurangzeb in his own compilation of Mughal law, the Fatawa al-Alamgiriyya. ${ }^{598}$

\footnotetext{
592 Ibid., p. 309.

${ }^{593}$ Ibid., p. 350.

${ }^{594}$ Ibid., p. 350. Sirhindi is quoted by Jahangir as saying, "This chastisement [imprisonment] has been a sufficient retribution for my soul; I will remain in your retinue."

${ }^{595}$ Ibid., p. 423. A sum of two thousand rupees was given Sirhindi, among other supplicants at the court, after the weighing ceremony celebrating Jahangir's fifty-fifth birthday.

${ }_{596}^{596}$ Ibid., p. 309.

${ }^{597}$ Johanan Friedmann, "Nizami, Naqshbandi Influence on Mughal Rulers and Politics," Islamic Culture XXXIX (1965), p. 44. Many Mughal courtiers of Central Asian origin were Naqshbandi murids who maintained regular relations with their Naqshbandi pirs while in India.

${ }^{598}$ Manuscript copies of Fatawa Naqshbandiyya are at the Oriental Institute in Tashkent and the Raza Library in Rampur. See S.A.A. Rizvi, "Sixteenth Century India," p. 156.
} 
While carefully retaining the traditional close Timurid family ties to the Naqshbandi order, the emperors Akbar and Jahangir chose to offer royal patronage to the much more socially liberal order of the Chishtiyyah. ${ }^{599}$ Mu'in al-Din Chishti (or Sijzi) had brought the order to India in the thirteenth century. Unlike the Naqshbandis, the Chishtis maintained a deliberate policy of identifying their order with the Indian subcontinent rather than continuing to look to Central Asian religious traditions for inspiration. The founder of the Chishti order had been heavily influenced by the syncretic and itinerant Qalandariyyah, ${ }^{600}$ an order known for renunciation and asceticism. The Chishtis having adopted a similar detachment, a shaykh of the order described their aesthetic: "The poor men (dervishes) are a community who consider sleep to be prohibited and become dumb when they utter anything, take straw and grass as their food and regard their association with the rest of mankind as a fatal viper so they can reach the stations of proximity to God." ${ }^{, 601}$

The Chishti policy of rejecting involvement in imperial politics (a policy to which they did not always adhere), use of a vocal zikr (repetitive invocation of the name of God) and sama' (ecstatic dance), and their easy dismissal of the limitations of legalist or conservative interpretations of Islam, suggests that the Chishti order was far more

\footnotetext{
${ }^{599}$ The Chishti order's origins in Transoxiana, centered for a time on the city of Osh in Babur's Ferghana Valley, assured Timurid awareness of the order long before their own migration to India. The Delhi sultans had been deeply involved with official patronage of the Chishti order. Babur visited and ritually circumambulated the lovely marble shrine and spiritual center at the tomb of Nizam al- Din Auliya (d. 1385) on his arrival as conqueror of Delhi.

${ }^{600}$ Thierry Zarcone, "Central Asian Influence on the Early Development of the Chishtiyya Sufi Order in India," The Making of Indo- Persian Culture, Muzaffar Alam, Francoise 'Nalini' Delvoye, Marc Gaborieau, eds., New Delhi: Manohar, 2000, pp. 110-1. It has been suggested that the common sharing of Qalandari traditions links the Chishtis of India with the Bektashis of Anatolia, who offered the Ottoman Turks a spiritual repository for variant religious expression, just as the Chishtis did for the Mughals. The Bektashi were known to have absorbed a great many Christians, as well as ex- Christian Muslims, and became the most influential religious order amongst the newly converted janissaries of the Ottoman court.
} 
representative of the religious values of the Mughal kings than was the Naqshbandiyyah. Yet what was perhaps far more important in the calculations of the Mughals, the Chishti order successfully crossed religious boundaries, attracting loyal Hindu adherents, with a broad public appeal that superseded religious communalism. The Chishti shrine at Amber is patronized by Muslim and Hindu worshippers; in the modern period its spiritual charisma attracts even a militant Hindu-nationalist constituency ${ }^{602}$

It was perhaps in an effort to attach his own political legitimacy to the spiritual sovereignty of the widely beloved Chishti order that Akbar performed his first pilgrimage to the shrine of the founder of the Indian branch of the Chishti order, Mu'in al- Din Chishti, in Ajmer in 1564, eight years after taking the throne. Akbar made annual journeys to Ajmer, at times barefoot, for fifteen years, at which point his youngest son, Danyal, took on the duty of the imperial pilgrimage. In an act presented as part of Akbar's well-documented search for spiritual enlightenment, as "a supplicant (niyazmand budan) of dervishes," he offered royal patronage to the Chishti shaykh Salim (d. 1571), who was said to have predicted the births of Akbar's three sons at a time in which the emperor was in despair over his lack of male progeny. ${ }^{603}$ Akbar's ceremonial capital of Fatehpur Sikri was carefully positioned next to the shrine of Shaykh Salim, with whom he had established a close relationship, attributing the birth of his first son, Salim, the future emperor Jahangir, to the power of the prayers of the Chishti shaykh for whom the child was named.

${ }^{601}$ Ibid., p. 104.

${ }^{602}$ Suketu Mehta, Maximum City, New York: Vintage Books, 2005, p. 82. Mehta describes a member of the nationalist Hindu political party, Shiv Sena, who had participated in anti- Muslim riots during the Babri Masjid riots and was reputed to have murdered Muslims, making regular and fervent pilgrimages to Ajmer and forgoing alcohol and cigarettes in observance of vows made at the Chishti shrine. 
Akbar's evolving aura of personal sanctity and increasing independence from outside sources of religious legitimacy may have finally inspired his eventual removal of the imperial court from Fatehpur Sikri. Yet even while no longer based at Sikri the next Mughal emperor, Jahangir, continued to show loyalty to the family of the Chishti shaykh who had been credited with intercession in his birth. The sons of Shaykh Salim, Jahangir's childhood playmates at Sikri, all of whom had been strategically separated from management of their father's dargah (tomb/shrine) by Akbar, were offered positions at the Mughal royal court. While retaining the inherited charisma of their family association, some Chishti descendants achieved distinction as mansabdars (office holders) in the Mughal nobility, the most successful being the shaykh's grandson, Islam Khan Chishti, who married a sister of Abu'l Fazl and completed the Mughal conquest of Bengal under Jahangir, reaching a high rank before his death in $1613 .{ }^{604}$

In addition to their public patronage of established and popular Sufi orders, Akbar and Jahangir indulged in the development of an imperial cult, a personal devotional movement within the royal household. It has been cogently argued that rather than a new religion, as he was reputed to have attempted in his din-i illahi, Akbar was attempting to create a Sufi order with himself as master, or pir. ${ }^{605}$ The enlistment of a small number of disciples, which can be understood as the logical extension of increasing Mughal imperial paternalism, was an important component of Akbar's religious system. Although

\footnotetext{
603 Jahangirnama, p. 2.

${ }^{604}$ Nawwab Samsam al-Daula Shah Nawaz Khan and Abdul Hayy, Maathir ul-Umara, pp. 692-3. Islam Khan Chishti reached the rank of 6,000 after his conquest of Bengal.

${ }^{605}$ Stephen Blake, "The Patrimonial- Bureaucratic Empire of the Mughals," The State In India, 1000- 1700, Hermann Kulke, ed., Delhi: Oxford University Press, 1995, p. 287.
} 
Akbar's was a more formal process, it not incidentally hearkens back to Babur's recommendation that his descendants socialize intimately with the imperial retinue in order to tie them to the throne. ${ }^{606}$ At the multi-ethnic, multi-religious royal court of Akbar, which included Rajput nobles, Persian intellectuals, Arab scholars, Turkish and Uzbek military men, local lineage chiefs and caste leaders, Jesuit missionaries, diplomats, mercenaries and merchants, efforts by the emperor to establish an imperial cult resulted in the creation of a body of intensely loyal courtiers in an intimate relationship with the emperor, regardless of individual religious, ethnic or hereditary service loyalties. ${ }^{607} \mathrm{~A}$ horrified cleric wrote that "the emperor considered his spiritual power as subservient to his secular power, ${ }^{, 608}$ and described the initiation ceremony of selected disciples, in which Akbar offered each a small portrait of himself: "They looked upon it [the portrait] as the standard of loyal friendship, and the advance guard of righteousness and happiness and they put it wrapped up in a small jeweled case, on the top of their turbans.."609

Jahangir imitated his father's enrollment of loyal courtiers and seems to have dabbled in identifying himself as a near deity or Sufi pir, while relinquishing his father's more extreme religious interpretations. In the middle of his reign he had his ears pierced and strung with pearl earrings as a gesture of affection and loyalty to "the great khwaja," and this act seems to have been replicated by his closest courtiers as a mark of personal discipleship. ${ }^{610}$ Jahangir not only accepted an inherited murshid (Sufi guide) status but

\footnotetext{
${ }^{606}$ Baburnama, Mano, p. 559. Thackston, p. 742. Complaining of Humayun's reported solitude, Babur wrote to him, "Solitude is a flaw in kingship... If you are fettered, resign yourself (agar payband-i rida pish gir)."

${ }^{607}$ Richards, "The Formulation of Imperial Authority,” pp. 268-9.

${ }^{608}$ Badauni,Tawarikh, II, p. 350.

${ }^{609}$ Ibid., p. 349 and p. 336.

${ }^{610}$ Jahangirnama, p. 152.
} 
his memoirs suggest that he was sincere in the role of spiritual leader to those young palace courtiers who bound themselves to him through oaths of loyalty.

A fascinating account by Mirza Nathan, a Mughal general and author of the Baharistan-i Ghaybi, a history of the Mughal wars of Bengal and Orissa, describes the process by which he became a disciple of the emperor Jahangir. Mirza Nathan was born in India of a noble Persian family and his father served both Akbar and Jahangir before his death in 1612. In the midst of a critical illness, Mirza Nathan dreamt that the emperor spoke to him: "O, Nathan! Is this the time for the Tiger to lie down? Arise! We have granted you security from pain and trouble by our prayers...."611 Waking in perfect health, Mirza Nathan sent word of the dream to his commander, Islam Khan. The emperor was subsequently informed and a decision made, at Islam Khan's urging, that Mirza Nathan would be "enlisted as one of the disciples of the sublime Court." the year, gifts and imperial orders were sent from the imperial court to the military officers serving in the Eastern provinces. While other officers received Arabian horses, a pearl studded gun, a matched pair of hunting panthers, and robes of honor, Mirza Nathan was sent, like the personal disciples of the previous emperor, "a special portrait of his majesty." Nathan clarified, "If any of the servants is included among the special disciples, he is favored with a portrait adorned with a genealogical tree. Therefore on account of the many devoted services... and the aforesaid dream about the Emperor... he was included in the circle of his disciples." 613

${ }^{611}$ Mirza Nathan ('Alau'd- Din Isfahani), Baharistan-i Ghaybi, M. I. Borah, tr., Gauhati, Assam: Narayani Handiqui Historical Institute, 1936, I, p. 17.

${ }^{612}$ Ibid.

${ }^{613}$ Ibid., p. 74. The genealogical tree, unsurprisingly, traced the dynasty's lineage from Jahangir to Timur. 
The portrait of discipleship, as in Akbar's time, was small and worn on the turban. "Nathan placed it on his head and honored himself by observing the formalities of obeisance and prostrations of gratitude. ${ }^{, 614}$ Notably, Nathan's conscription into the circle of Jahangir's disciples was effected without requiring his return from the battlefield to the imperial court, nor does he seem to have been at any point consulted regarding his desire to be initiated, although surely his dream narrative confirmed his possession of personal loyalty to the emperor at the appropriate level of intensity. The number of imperial disciples under both Akbar and Jahangir seems to have remained relatively small and the men included were, like Nathan, young and enthusiastic. While the emperor benefited from the presence of a specific, named cadre of the most loyal officers of the court, as Mirza Nathan shows us, these loyal disciples served their "pir/emperor" in various capacities at sensitive posts on the far-flung borders of the empire.

Yet throughout the period of what might be considered a Chishti ascendancy and what was viewed by conservatives as a rejection of traditional understandings of Islamic identity, ${ }^{615}$ Mughal awareness of the Timurid past continued to encourage imperial allegiance to traditionally Timurid religious institutions, even those with which the Mughal kings seem to share little. The conservative Naqshbandis had been politically influential in the post- Timur royal courts of Central Asia, and although they never developed the same degree of influence on the construction of Mughal political ethics nor on Mughal rule in India, the Mughals persistently displayed loyalty to the ancestral order,

${ }^{614}$ Ibid. 
maintaining their status as a noble family at the imperial court. No wonder a disgruntled Chishti shaykh, frustrated at ineffective attempts to influence the sixth Mughal emperor, Aurangzeb, wrote that, "the Emperor of Hindustan is a descendant of Amir Timur and Amir Timur was spiritually attached to Shah-i Naqshband. These Turanians, all and every one of them, are connected with the Naqshbandi order and they do not attach value to any other silsilah." 616

The expansion of the Naqshbandiyya into the subcontinent had been facilitated by Mughal patronage during the imperial conquest, and Naqshbandi immigration to India from Transoxiana was steadily maintained throughout the entire Mughal period. In time, the famed Sirhindi would become known less for his relationship with the Mughal kings than for the dramatic impact of his writings on global tasawwuf (Sufi devotionalism) and the active proselytizing of his spiritual successors. Known as the renewer (mujaddid) of the pristine purity of the doctrine of Islam, Sirhindi instigated a shift from the Naqshbandi's Central Asian khwajagan to an Indian mujaddidi period. ${ }^{617}$ His extensive and acclaimed writings, the Maktubat, so reviled by Jahangir, have been described by modern scholars as "a kind of diffuse encyclopedia of Sufi knowledge and guidance," while Sirhindi's vast and influential lineage, known as the Naqshbandi-Mujaddidi, became widely diffused across India and expanded rapidly into the Middle East and Anatolia. ${ }^{618}$ In yet another of those remarkable circular ethical and religious migrations, the mujaddidi carried their movement back into Central Asia, where it proceeded to

${ }^{615}$ For example, see Badauni, Tawarikh, II, p.215: "The observance of the five prayers and the fasts and the belief in everything connected with the Prophet, were put down as mere superstition, and man's reason, not tradition, was acknowledged as the only basis of religion." Also pp. 349-50.

${ }^{616}$ Maktubat-i Kalimi, Letters of Shah Kalimullah of Delhi, Delhi, 1302 AH, p. 75, in Khaliq Ahmad Nizami, State and Culture in Medieval India, New Delhi: Adam Publishers, 1985, p. 160. 
almost entirely displace the formerly hegemonic khwajagan Naqshbandis. ${ }^{619}$ Modern developments in Naqshbandi Sufism, particularly its evolution into the Jaddidiyya movement and then the Khalidiyya, should not however be viewed as a rejection of the Ahrari lineage of India’s original Naqshbandis. Instead they represent a broad tendency towards continuity, taking advantage of the order's intimate alliance with the TimuridMughal court and building on Ahrar's Central Asian model of political integration. The modern Naqshbandi community of the Indian subcontinent and across the Muslim world remains an important component of the Timurid- Mughal legacy and represents a casestudy of Timurid- Mughal participation in global Muslim trends and influence on the Islamic world.

Of course it is also true that not all Naqshbandis were subsumed into the Mujaddidi or its nineteenth- century offshoot, the Khalidiyya. A recent study of a

${ }^{617}$ Dale and Payind, p. 226.

${ }^{618}$ Hamid Algar, "The Naqshbandi Order: A Preliminary Survey,” Studia Islamica 44/136 (1976), p. 145

${ }^{619}$ Ibid.. The first major westward migration of the Naqshbandi- Mujaddidi, was that of two Bukharans, Sheikh Ahmed Jarullah Juryani (Yakdast) and Muhammad Murad al- Bukhari, who were initiated into the order by Khwaja Muhammad Ma'sum, Sirhindi's middle son and primary successor, while on a spiritual journey to India. From India they migrated to the Middle East and Anatolia to initiate their own Mujaddidi disciples. A Naqshbandi- Mujaddidi tekke was established by successors in Istanbul in the early eighteenth century, becoming a center of Mujaddidi activity in the Ottoman capital and sending out disciples to establish the order in the Balkans. A second and critically important westward Mujaddidi migration was that of the Kurdish Mawlana Khalid Baghdadi (d. 1827), directed to India by a Meccan sheikh who told him, "Your guide awaits you there." (Ibid., p. 147) He returned after more than a year of study under Shaykh Abdullah Dihlavi in Delhi to spread Mujaddidi doctrine in Baghdad and Damascus. His lineage, which has become known as the Khalidiyya, developed a powerful political role and came to dominate Naqshbandi activity in the west, including the Hijaz, Iraq, Kurdistan, Anatolia, and the Balkans and east, in Sri Lanka, Mozambique, Sumatra, and the Malay Peninsula

Retaining the traditional Naqshbandi ideal of strict implementation of the shari'a, the KhaldiyyaNaqshbandis are known for their support of militant resistance to westernizing tendencies in all of its territories. Khalidis struggled against nineteenth- century Tanzimat reforms in Ottoman territory as well as the twentieth- century secularization of the Turkish Republic, and the Naqshbandis continue to play a vital role in twenty- first century Turkish religio- political movements. In the twentieth-century, Syrian Naqshbandi- Khalidis battled on behalf of Syrian Kurdish nationalism, participated in Achehnese wars of independence against the Dutch, actions against Thai rule in Malay Patani, and "contributed to the ferment of Muslim militancy in the Southern Philippines" (Ibid., p. 151). Other modern political movements led by Naqshbandis include a struggle against Russian occupation in Daghestan in the North Caucasus and in Babur's province of Andijan, in 1898, and against Chinese rule in Shensi, Kensu and Sinkiang. 
Naqshbandi lodge in the southern Indian city of Awrangabad describes strong Central Asian khwajagan Naqshbandi affiliations lasting until the end of the eighteenth century. Remarkably, even through the period of Mughal imperial decline the most important members of the Awrangabad Naqshbandi community continued to be recent immigrants from Transoxiana, affiliated with the order in India because of their place of origin in Balkh or Bukhara. ${ }^{620}$ Their models for proper behavior remained the great fifteenthcentury khwajas of Transoxiana and their writings, in their descriptions of behaviors and use of Persianate idioms and anecdotes, seem to have been modeled on earlier Naqshbandi texts of Central Asian origin. ${ }^{621}$ The Naqshbandi tekke remained a vital and integral part of Awrangabad's Muslim community until the early twentieth century, at which time its ultimate failure may have been due to the tekke's reliance on the regular immigration of an elite foreign (i.e., Central Asian Turkish khwajagan) population. ${ }^{622}$ Zikr was, however, still being routinely performed at the tomb of its founder, Shah Muzaffar, in 1995.

\section{The Literature of Ethics and the Mughal Library}

The success of Timur and generations of Timurids in developing a publicly acceptable presentation of imperial piety and justice was aided by a pre-existing body of literature which the Timurids artfully employed to explain and articulate, even support and condone, the understanding of social and ruling ethics that had sprung from their merger of Chingizid and Perso-Islamic ideals. These carefully articulated Timurid

\footnotetext{
${ }^{620}$ Simon Digby, Sufis and Soldiers in Awrangzeb's Deccan, New Delhi: Oxford University Press, 2001.

${ }^{621}$ Ibid., p. 3.

${ }^{622}$ This is Digby's suggestion.
} 
ethical understandings were delivered to and sustained by the Mughals in the form of an immutable body of canonical literature, beloved by Timurids and Mughals alike.

Timurid political philosophy was most heavily influenced by a thirteenth- century Persian treatise on political ethics, the Akhlaq-i Nasiri, composed by Khwaja Nasir alDin Tusi. ${ }^{623}$ Originally intending his work as advice literature for Ismaili rulers in Iran, Tusi adjusted to political realities and instead offered his treatise to Iran's Mongol invaders, adding only an introductory paean to the region's new power. Tusi's work spread widely across the Islamic world, gaining acceptance and influence in Timurid Transoxiana, among other regions. Sultan Husayn Bayqara patronized scholarship based on the Nasiri ethos, and at least two imitations of Tusi's work were produced at his court. ${ }^{624}$ On the heels of the Uzbek rout of the Timurids, the author of one of these simplified, local interpretations of Tusi's political philosophy, Ikhtiyar al-Din al-Husayni, re-entitled his work Akhlaq-i Humayun and formally presented it to Babur, then in Kabul, to serve as an ethical and political guide to the last independent Timurid prince and his descendants. ${ }^{625}$ The Mughals in India, however, seem to have preferred the earlier version and Tusi's original study became the central text representing Mughal morality and ruling ethics.

It is easy to understand Timurid- Mughal loyalty to Nasiri ethics, which was after all presented by the author to the non- Muslim Mongol rulers of newly conquered Iran as

\footnotetext{
${ }^{623}$ Nasir al-Din Tusi, Akhlaq-i Nasiri, $5^{\text {th }}$ ed., Tehran: Shirkat-i Salami-ye Intishirat-i Khorazm, 1373 (1994).

${ }^{624}$ Hoseyn Va'iz Kashefi, Akhlaq-i Muhseni, Bombay, 1308/1890 (The Practical Philosophy of the Mohammadans), and Qazi Ikhtiyar al-Din al-Husayni, Dastur al-vizarat, are in manuscript form in the Bibliotheque Nationale de France, Paris (BN), as in Muzaffar Alam, "State Building Under the Mughals," p. 126.

${ }^{625}$ The assumption by modern scholars is that this work was his earlier study, the Dastur al-Vizarat, given a new title to better suit the author's new patron, Babur. Ibid.,p. 14.
} 
a manual for kingship. If it were to be appropriate for Mongol rule Tusi's ethical construct could not advocate narrow, legalist adherence to Islamic law. Rather than argue for the centrality of doctrinal Islam and the strict imposition of shari $a$ in governance, Tusi instead affirms the place of a ruler's nobility of person and lineage (sharaf-i hasab u nasab), while emphasizing the king's role as "arbitrator in equality" (padshah-i adil hakimi bi-sawayat bashad). ${ }^{626}$ The government of the realm, writes Tusi, must be virtuous, "its purpose being the perfection of men, and its consequence the attainment of felicity." In a statement remarkable in the context of medieval monarchy, Tusi asserts that legitimate government, "holds fast to justice (adalat), treating its subjects (ri'ayat) as friends.... [rather than] servants and slaves (khawal u'abid)., ${ }^{\prime \prime 27}$

In Tusi's ethical construct, human reason is granted precedence over established religious legal code and the requirement of royal justice dilutes the absolute power of the ruler in the interests of the subjects' well being. In contrast to Nizam ul-Mulk's support for the suppression of political dissent as the critical component of royal justice, ${ }^{628}$ Tusi describes justice as the act of balance among diverse and sometimes conflicting special interest groups within a single state. "The affairs of living thus must be administered through cooperation (shirkat u mu'awant) which in turn depends on justice (' $a d l$ ). If 'adl disappears each will then follow his own desire... But Shari'a cannot work without it being administered by a just king, whose principal duty is to bring the people in control

\footnotetext{
${ }^{626}$ Nasir al-Din Tusi, Akhlaq-i Nasiri (The Nasirean Ethics), G.M. Wickens, tr., London: George Allen and Unwin, Ltd., 1964, p. 99.

${ }^{627}$ Ibid., p. 227.

${ }^{628}$ Nizam ul- Mulk, Siyasatnama (The Book of Government), Hubert Darke, tr., London, Boston: Routledge \& Kegan Paul, 1978.
} 
with affection and favors." ${ }^{229}$ The necessity of tolerance, mutuality, even the existence of a social contract between ruler and subject, is implicit in Tusi's argument. "The principles underlying states derive from the agreement of the opinions of a community who, in respect of cooperation and mutual assistance, are like the members belonging to an individual; if such an agreement be commendable, we have a true state; otherwise it is false. ${ } 630$

The paternalist benevolence of Tusi's tolerant humanism suited well the character of the Timurid- Mughal kings who ruled pragmatically over a diverse and polyglot empire in which Islam was a minority religion. ${ }^{631}$ The emperor Akbar's chief minister, Abu'l Fazl, declared the Akhlaq-i Nasiri among the five most important works for the emperor Akbar and his administrators to read, had it read aloud to the emperor nearly every day, and claimed it had enormous influence on Akbar's governing philosophy. It became a staple in the curriculum of Mughal madrasas and, confirming imperial commitment to Tusi's religious tolerance, a letter was sent to local Mughal administrators across the empire instructing them to be particularly attentive to Tusi's message of tolerance. ${ }^{632}$ Akbar had Tusi's political philosophy beautifully illustrated in his court ateliers.

Nasir al-Din Tusi offered the Mughals an articulate and scholarly argument which could be strategically expounded to legitimize their state policy of tolerance and religious pragmatism within the context of legitimate Sunni political discourse and without

\footnotetext{
${ }^{629}$ Muzaffar Alam, "Akhlaqi Norms and Mughal Governance," The Making of Indo- Persian Culture, Muzaffar Alam, et al., eds., New Delhi: Manohar, 2000, p. 78 (trans., Alam).

${ }^{630}$ Ibid., p. 229.

${ }^{631}$ Tusi claims that while justice is the most important virtue in a king, it is closely followed by benevolent kindness (ihsan). Tusi, Nasirean Ethics, p. 233.
} 
threatening the dynasty's formal religious loyalties. Jahangir's description of his father, Akbar, seems to reflect the influence of Tusi, stressing the humility of Akbar, philosopher-king, and his non- sectarian but heartfelt spirituality. "In spite of his rulership and such treasuries and treasures beyond reckoning or comparison, in spite of his war elephants and Arabian horses, he never did place his foot even a hairsbreadth beyond humility before the court of God (dargah illahi), and he considered himself the most insignificant (kamtarin) creature of all created beings. Not for an instant was he unaware of God....Loving universal peace was his established way (sulh-i kul shiwa maqarar ishan bud).,"633

Tusi's tolerant spirit found fertile ground in a society informed by Islamic mysticism and the Persian poetic culture which was ubiquitous in Timurid Transoxiana and which had remained of central importance among the descendants of Timur in Mughal India. The greatest trio of poets in Persian history formed the heart of the Timurid- Mughal library: Jalal al-Din Rumi, who was born in Balkh in 1207 yet fled the Mongol invasion into Anatolia, where he wrote the deeply spiritual Mathnawi and established himself as a Sufi master known as Khudavandigar (Lord), Hazrat (Saint) and Mawlana (our master); Shams al- Din Muhammad Hafiz, born in the fourteenth-century in Shiraz, where he remained his entire life, composing his Divan, of which over five hundred poems survive; and the thirteenth-century Sa di (ca. 1208- 1291), also from Shiraz, although educated in Baghdad and a well traveled man, he composed several volumes of verse, ghazal and qasideh, as well as the Gulistan and Bustan. Although each

\footnotetext{
${ }^{632}$ Alam, “Akhlaqi Norms," pp. 84-85.

${ }^{633}$ Jahangirnama, p. 22. Sulh is pacification, reconciliation, peace, concord. Kul is the universal, all, the whole. Akbar's name for his political philosophy was the Sulh-i kul, universal peace.
} 
of the three had a distinctive literary voice, they shared a fascination with issues of ethics and morality, articulating a unified vision of tolerance, social justice, the rejection of narrow religious heterodoxy, and a passionate spirituality grounded in Islam.

Religious Tolerance: "The Idiom of Hind is Praiseworthy"

Much Sufi doctrine had been fundamentally influenced by the spiritual thought of Muhyi al-Din ibn al-Arabi (d. 1240), who emphasized a spiritual ideology which was interpreted by many as wahdat al-wujud, "Unity of Being." This came to be understood, particularly among the popular and influential medieval Persian poets, as an equality of religious expression - the implication surely intended by Ibn al-Arabi himself, who wrote, in his Tarjuman al-Ashwaq:

My heart has become capable of every form; it is A pasture for gazelles and a convent for Christians And a temple for idols and the pilgrim's Kaaba and The tables of the Torah, and the book of the Koran. I follow the religion of Love; whatever way Love's camels Take, that is my religion and my faith. ${ }^{634}$

Given their devotion to the literature, this encouragement to accommodate diverse religious traditions surely was a significant affirmation of imperial values among Timurid and Mughal rulers. Jalal al-Din Rumi, who was a contemporary of Ibn al- Arabi, wrote directly and specifically of the universality of belief.

Though the ways are various, the goal is one. Do you not see that there are many roads to the Kaaba? For some the road is through Rum, for some from Syria, for some from Persia, for some from China, for some by sea from India and Yemen.

${ }^{634}$ Ibn Arabi, Tarjuman al-Ashwaq, R.A. Nicholson, tr., London, 1911, p. 67. 
So if you consider the roads the variety is great and the divergence infinite; but when you consider the goal, they are all of one accord and one.",635

Rumi's masnavi, which the Emperor Akbar is said to have committed to memory, contains the verses:

Tu bara-yi vasl kardan amadi

Na bara-yi fasl kardan amadi

Hindayan-ra istelah-i Hind madh

Sindiyan-ra istilahie Sind madh.

Thou hast come to unite,

Not to separate.

For the people of Hind, the idiom of Hind is praiseworthy,

For the people of Sind, their own is to be praised. ${ }^{636}$

Dar mazab ashq u ashq ra mazhab nist

Ashq an bahrist kash karan u lab nist.

In every religion there is love, but love has no religion,

Love is an ocean, without borders or shores.... ${ }^{637}$

Equally clear regarding the requirement of religious tolerance is $\mathrm{Sa}^{\circ} \mathrm{di}$, writing:

Each person takes a road in search of you. Had there

Been any way to you, there would not have been so many roads.

Hirkis barhi miravad indar talibat

Gar ruh budi binadi inhame ra. ${ }^{638}$

Rather than speculate on the degree to which this literature may have constructed religious thought in medieval Central Asia, it is possible that it found comfortable accommodation in pre-existing post- Mongol religious pragmatism, serving the Timurids

\footnotetext{
${ }^{635}$ Jalal al-Din Rumi, Fihi ma fihi (Discourses), quoted in Sufi Essays, Seyyid Hossein Nasr, ed. and tr., Albany, NY: State University of New York Press, 1991, p. 149.

${ }^{636}$ Jalal al-Din Rumi, Masnavi, quoted in Muzaffar Alam, "State Building under the Mughals," p. 119.

${ }^{637}$ Masnavi, in Shahram T. Shiva, ed. and tr., Rending the Veil: Literal and Poetic Translations of Rumi, Prescott, AZ: Hohm Press, 1995, p. 24.

${ }^{638} \mathrm{Sa}$ 'di, A Thousand Years of Persian Rubaiyat, Reza Saberi, tr., Bethesda, Maryland: IBEX Publishers, 2000, p. 286.
} 
by articulating an already firmly held ethical paradigm. What is certain is that Timurid society did allow for a degree of fluidity within individual religious identity. As we have already seen, popular religious movements in Central Asia, while nominally Sunni, developed a high degree of "confessional ambiguity" in their inclusion of extreme Alid concepts. ${ }^{639}$ Ever pragmatic, the Mughal dynastic founder Babur outwardly converted to Shi' ism in an effort to gain the support of the Safavid Shah in his third attempt to conquer the Timurid capitol of Samarqand, although he abruptly dropped his Shi'i allegiances after again losing control of the capital city. His son Humayun, in his own desperate battle to reclaim his patrimony, followed in his father's footsteps and bowed to religious conversion in exchange for Safavid assistance in his ultimately successful attempt to reconquer Northern India. He too reverted to the family's traditional Sunni allegiance as soon as the need for Safavid aid had passed. Humayun's son Akbar was renowned for his heterodox religious allegiances, and Jahangir seems to have been quite willing to concur with his father's lack of interest in traditional forms of conservative Islam. Pragmatic political and personal manipulation of what seems to have often been a deeply felt, yet remarkably fluid, religious identity reflects a high degree of continuity between the Timurid and Mughal dynasties.

Mughal flexibility and acceptance of non- Muslim religious identity was extended to the individuals at their Indian court, where the varied religious affiliations of Mughal women reflect the family's high degree of spiritual insouciance. Iranian Shi'i wives were common within the family, while all Mughal emperors from the time of Akbar, along with their sons and brothers, married into the Hindu Rajput royal families. Although all

${ }^{639}$ John E. Woods, The Aqquyunlu: Clan, Confederation, Empire, Salt Lake City: University of Utah Press, 240 
of the dynastic progeny were raised as Muslims, the wives and concubines of the Mughal kings, in common with Mughal courtiers, were not required or expected to convert to Sunni Islam, and all evidence suggests that a variety of faiths co-existed harmoniously within an imperial palace complex that housed mosques, chapels and fire temples. Jesuit visitors to the Mughal court were allowed to convert Jahangir's two nephews to Christianity, although the emperor's motives were quite likely influenced by the knowledge that, as Catholics, the princes would no longer be considered viable rivals for the Mughal throne. While Hindus had long participated, to varying degrees, in governance under the Delhi sultans, the Mughals opened their military bureaucracy to an unprecedented level of non- Muslim involvement, leading a conservative Muslim scholar at the court to complain of "Hindu infidels who are indispensable and of whom half the army, and the country, will soon consist, and as whom there is not among the Moghuls or Hindustanis [native Muslims] a tribe so powerful." ${ }^{, 640}$

The emperor Jahangir celebrated his dynasty's acceptance of diversity and rejection of narrower political codes, patronizing political writings, which like that of Tusi, emphasized the independent nature of justice and desirability of religious tolerance. Describing his father's and his own imperial court, Jahangir proudly wrote, "Followers of diverse sects (irbab-i milal-i mukhtalafa) are given a place in his broad and matchless empire - unlike other countries in the world, like Iran, where there is room only for Shiites (Shi 'i ra begir Iran), and in Rum, Turan, and Hindustan, where there is room only for Sunnis (Sunni ra dar Rum u Turan u Hindustan). Just as all peoples and all sects have a place within the spacious circle of God's mercy... in my father's realm, which is 
bounded by the salty sea, a place is made for all religious sects and beliefs, conflicting and skeptical, and oppression ( ta $^{\prime}$ 'iz) is not allowed." ${ }^{, 641}$

Reflecting an agreement with such comments as that of the poet Hafiz, who wrote, "The link between man and the Beloved, which God created from nothing, is something that no high priest or scholar can explain, ${ }^{642}$ the Mughals rejected an intimate relationship with the ulama, which surely made their routine and habitual public patronage of sincere piety in all of its incarnations, Muslim or non- Muslim, particularly valuable. While the ulama had been given a prominent public position in the court of Timur, who is described as regularly engaging religious specialists in public intellectual debate, their political influence on the great Amir was certainly never very profound. ${ }^{643}$ Indeed, accusations of insincere Islamic identity directed at the Timurids and Mughals were often inspired by their rejection of narrow interpretations of legalist Islam, which held limited appeal for Timur and the majority of his descendants. While the Mughal kings did not hesitate to define themselves in classic terms of Perso- Islamic kingship, this dynastic presentation was coupled with a seemingly careless disregard for conservative Islamic jurisprudence, as the Mughal court continued to display varying degrees of disinterest in proponents of conservative Islamic legalism. In the context of Hindu India, the question of coordination of Islamic law, the shari' $a$, with the realities of rule was resolved by the marginalization of conservative Muslim legalists and religious law. A conservative 'alim at Akbar's royal court wrote in outrage that Hindus were

\footnotetext{
${ }^{640}$ Badauni, Tawarikh, II, p. 350.

${ }^{641}$ Jahangirnama, p. 22. Thackston, tr., p. 40.

${ }^{642}$ Hafiz, Drunk on the Wine of the Beloved: 100 Poems of Hafiz, Thomas Rain Crowe, tr. and ed., Boston and London: Shambhala, 2001, p. 8.
} 
encouraged, yet the emperor offered to loyal Muslims like himself "nothing but kicks and blows, and utterly disregarded all their devotion and zeal and complaisance."644

While mosque construction was a commonly asserted act of piety by members of the dynasty from the time of Timur, attendance at religious services almost entirely escapes comment in the family chronicles. Although they mention regular visits to various Sufi shrines, neither Babur nor Jahangir refers in his memoirs to more than a single visit to a mosque. On his ascension to the throne, Jahangir decreed that the allowances of the women of the family be raised from between twenty to one hundred percent but in contrast the emperor only confirmed the salaries of religious clerics, offering them no increase in salary at all. ${ }^{645}$ Although allowed a place at court, the ulama continued to be denied substantial influence and played a minor role in establishing the religious and political credentials of the Mughals.

While the role of the ulama was dramatically circumscribed, Mughal rulers patronized various non- Muslim religious figures. Jahangir and Akbar were known for their respectful patronage of Hindu ascetics who seemed to them to be sincere in their piety. Akbar had visited a famed sanyasi, Jadrup Gosain of Ujjain, an event his son claims he "always recalled fondly."646 Jahangir's description of Jadrup indicates enormous respect on the part of the emperor; he made a great effort to reach "a barren corner far from cultivated lands" where he found the "narrow, dark hole" in which the

\footnotetext{
${ }^{643}$ Ibn Arabshah, Tamerlane, p. 312-4. It is amusing to note, and very much in the character of the Timurids, that ibn Arabshah lists the names of the ulama at Timur's court together with the names of the emperor's court orators, calligraphers, astronomers, goldsmiths and chess players.

${ }^{644}$ Badauni, Tawarikh, II, p. 350.

${ }^{645}$ Jahangirnama, p. 6. Thackston, p. 26.

${ }^{646}$ Jahangirnama, p. 203.
} 
sanyasi murtazi lived. ${ }^{647}$ The emperor had long "wanted to call him [Jadrup] to the court at Agra," yet he avoided summoning the ascetic, acknowledging the difficulty of the request. ${ }^{648}$ When Jadrup later moved to Mathura, an important Hindu temple site on the Yamuna River, Jahangir visited again. "Since I was anxious to talk to him," he wrote, "I went to see him and spent a long time alone with him without interruption. He is infinitely valuable and from his company one can gain great contentment and strength." ${ }^{649}$

Full of admiration, Jahangir draws a remarkable connection between Islamic and Hindu scriptural study: "He really has more than a little learning," wrote the Muslim Mughal emperor, "and has studied well the science of the Vedanta ('ilm-i bidanat) which

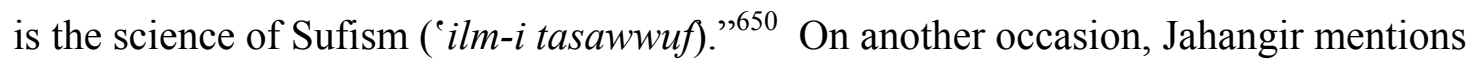
visiting yet another Hindu ascetic with whom he "spent a long time conversing. He was not devoid of intelligence or understanding (khayli az agahi u ma 'qulit nist)," wrote the emperor, "and knew all about the principles of Sufism (muqadamat-i Sufiya) in his religion... It can be strongly said that no one of this type (az in ta 'ifa) better than he has been seen." ${ }^{651}$ Here too Jahangir seems to conflate Hindu and Muslim ascetic spirituality by explaining his interest in the sanyasi “... as I was always ready to receive advice from dervishes (Chun khatir hamwara be nasihat-i darwishan ragib ast). ${ }^{.652}$

\footnotetext{
${ }^{647}$ In describing Jadrup Gosain, Jahangir uses the Sanskrit term sanyasi rather than the Persian darwish, then couples it with the Persian term murtazi, stressing ascetic discipline. Jahangirnama, p. 202.

${ }^{648}$ Ibid.

${ }^{649}$ Ibid., p. 316.

${ }^{650}$ Ibid., p. 202.

${ }^{651}$ The term ta ifa can be translated as "sect," but in this context, given Jahangir's consistent conflation of Islamic Sufism with Hindu asceticism, and the topic of his discourse being ascetics in general, rather than Hindu religious practices, "type" seems most appropriate.

${ }^{652}$ Ibid, p. 268.
} 
Yet Jahangir was not blindly susceptible to the spiritual claims of those Hindu or Muslim religious leaders who seemed, to him at least, to lack real personal piety. Just as the Naqshbandi Shaykh Sirhindi was declared to be a charlatan, so too Hindu mystics faced the judgment of the emperor. As we have seen, Jahangir sought out and enjoyed debating the relative merits of religion with Hindu pundits (punditan) ${ }^{653}$ and seeking out "a real fakir from whose conversation some great bounty might derive." ${ }^{.654}$ The emperor modeled himself on his father, who "conversed with the good of every religion and every sect (ba nikan $u$ khuban har ta 'ifa, $u$ har din $u$ a'in suhbat mi dashtand) and gave his attentions to each according to his station and ability to understand (baqadar halat $u$ fahmidi)." ${ }^{\prime 655}$ Jahangir's respect, and subsequent financial generosity, was based on his sense of an individual's sincerity, and when visiting a major temple site, "alms of cash and goods [were given] to each one according to his merits (istihqaq). ${ }^{"} 656$ On one of his many tours of Hindu temple sites, Jahangir wrote contemptuously of the rarity of true spirituality, comparing the truly pious to the phoenix ('anqa) and the philosopher's stone (kimiya ). ${ }^{657}$ "All I saw," he wrote, "was a flock of petty fools (bi ma' rafat), and the result of my seeing them was nothing but mental confusion and obfustication (tiragi khatir)." When Jahangir felt a false guru might be actively manipulating a gullible public he ordered "the place destroyed, the yogi driven away and the idol... smashed," emperor remained uncritical of the Hindu worship of God "according to their religion."

\footnotetext{
${ }^{653}$ Ibid., p. 19. The word pundit is Sanskrit.

${ }^{654}$ Ibid., p. 60.

${ }^{655}$ Ibid., p. 23.

${ }^{656}$ Ibid., p. 384

${ }_{657}^{657}$ Ibid., p. 60. The 'anga is also commonly known in Persian literature as the simurgh.

${ }^{658}$ Ibid., p. 145.

${ }^{659}$ Ibid., p. 384.
} 


\section{A Social Contract: "The Shepherd Must Serve the Sheep"}

Far more than the other poets in the Mughal library, the Persian philosopher- poet Sa di Shirazi came to be known for his direct and clear advice to rulers, often in the form of parables, stripped bare of the obscurity imposed by Hafiz's lyric allegory or Rumi's passionate spiritual references. His work can be positioned within the Mirror for Princes literary genre, while fitting comfortably with the aspirations and values of the TimuridMughals. Without denying the power of royalty, Sa'di affirms Tusi's insistence on the existence of a social contract in which the ruler is required to impose justice and protect the subjects. In Sa'di's ethical construct, it is the task of the ruler to serve his subjects.

You have heard that some ancient shahs of Persia

Ruled with injustice the people of Persia

Neither did their majesty and pageantry last long

Nor did their injustice to the peasantry last long

When an unjust ruler commits an injustice

The world survives but he dies with his injustice....

The ruler does not deserve to sleep well

When under him the strong exploit the weak. ${ }^{660}$

Try to look after the poor and needy

Do not think of your own well- being

No-one will live in peace and comfort

If you seek only your own betterment...

The sultan is a tree, his subjects are the roots

The tree stands on the strength of its roots... ${ }^{661}$

Sa di's direct advice to rulers resonates in the history of Timurid- Mughal

princely ethics; remembering Jahangir's respectful visit to the Hindu ascetic, Jadrup, the influence of Sa di's parables is evident in the behaviors and religious- ethical understandings of the Mughal kings of India.

\footnotetext{
${ }^{660}$ Sa'di, Bustan, in Thousand Years of Persian Rubaiyat, p. 130.

${ }^{661}$ Ibid.
} 
A reclusive dervish was living in an isolated spot," he wrote. "A Shah passed him by but, given the lack of need associated with the realm of contentment, the dervish did not acknowledge him. Given the majesty of kingship, the sultan was hurt and said, 'These ascetics are like animals and lack civility and humanity.' The vizier approached the dervish and said, 'Chivalrous sir, the lord of the land passed you by. Why did you not display humbleness and show respect to him?' He replied, 'Tell the Sultan to expect service from one who expects a favor from him. And further than that, he should know that shahs exist for protecting the subjects, not the subjects for serving the shah... The sheep do not exist for the shepherd, it is the shepherd that must serve the sheep."662

Others were, of course, heavily influenced by this Perso-Islamic political paradigm. At the Ottoman court the sixteenth- century political philosopher Kinilazade offered a version of a "Circle of Equity" that defined the just state:

There can be no royal authority without the military; There can be no military without wealth; The reaya (subjects) produce the wealth; Justice preserves the reaya's loyalty to the sovereign; Justice requires harmony in the world; The world is a garden, its walls the state; The shari ' $a$ (holy law) orders the state; There is no support for the shari 'a except through royal authority. ${ }^{663}$

The earliest efforts at kingship by Babur's great- grandson, Jahangir, who had inherited a successful and sedentary empire and for whom the ghazi ethos had grown increasingly irrelevant, reflect a fascination with the Persianate model of Islamic sovereignty and its demands for royal justice and charity. At least in theory, Jahangir accepted the responsibility of a social contract, and described his own interpretation of the classic "Circle of Justice:" "Whenever a just and equitable monarch's (sulatin ma'dalat a'yin masruf) mind and intention are turned to the people's welfare and the

\footnotetext{
${ }^{662}$ Sa'di, Kulliyat, in Ibid., pp. 132-33.

${ }^{663}$ Douglas A. Howard, "Ottoman Historiography and the Literature of 'Decline' of the Sixteenth and Seventeenth Centuries," Journal of Asian History 22 (1988) 52-77, p. 57.
} 
peasant's tranquility (rafahiyat-i re'aya), then prosperity, blessings, good crops and produce are immeasurable. ${ }^{.664}$ Sensitive to calls for royal acts of justice, Jahangir's response to news of tyrannical behavior by the eunuchs of an important amir was to write immediately to chastise the offenders, claiming in his missive that his own "sense of justice did not tolerate oppression and that in the scales of justice, greatness and smallness were not sanctioned ('adalat-i ma az hich kas sitam bar nimidarad dar mizan-i 'adl khurdi u kalani manzur nist)." ${ }^{965}$ Jahangir regularly and publicly confirmed his regnal emphasis on Islamic ideas of justice within the ideology of kingship as "refuge to the oppressed and a protector of the fallen." ${ }^{, 666}$ His absorption with Persio-Islamic precedents for imperial responsibility is illustrated by his very first act as sovereign, ordering a golden "Chain of Justice" (silsilah-i 'adl or bustan zanjir-i 'adl) strung with sixty bells and hung between the banks of the Yamuna river and the peak of the citadel at Agra, enabling petitioners to bypass those clerks at the imperial law courts (mutasadiyani muhimat dar al-'adalat) who were not attentive to the needs of the empire's subjects. ${ }^{667}$ Those of the king's subjects who felt they had been wronged could in this way gain personal and direct access to the king, wellspring of imperial justice, in time of need. Miniature paintings of the period indicate that the "chain of justice" remained in place in the period of Shah Jahan, who, like his father, was portrayed with it as backdrop.

Of course maintaining a theoretical interest in the well- being of his subjects, no matter how well intentioned, did not always translate into successful imperial actions. A

\footnotetext{
664 Jahangirnama, p. 285.

${ }^{665}$ Ibid., p. 9. Thackston, tr., p. 28.

${ }^{666}$ Linda T. Darling, “'Do Justice, Do Justice, For That is Paradise!’: Middle Eastern Advice for Indian Muslim Rulers,"Comparative Studies of South Asia, Africa, and the Middle East, XXII, nos. 1\&2 (2002), p. 10 .
} 
facetious comment made by Jahangir to a village blacksmith, at court to appeal for the emperor's intervention in a matter of the heart, ended with the blacksmith throwing himself from the palace window to prove to the emperor the depths of his passion for a local widow. Although Jahangir called for court physicians to tend to the man, the blacksmith died of his injuries. While his careless words had caused the death of the lovelorn blacksmith yet Jahangir did, somewhat apologetically, include the story in his memoirs, illustrating to his readers the degree to which this monarch was involved in dispensing justice amongst even the most lowly of subjects. ${ }^{668}$

\section{"Be a Friend of Wine"}

Among the most influential of the great medieval Persian poets at the Mughal court was Shams al-Din Hafiz, master of the poetic form known as the ghazal. Apart from the unquestionable beauty of his verse, the reasons for Hafiz's popularity are many but include the common use of his poetry as an oracle, a device for fortune-telling. Unlike the qasidah, a poetical genre employed in courtly panegyric, the ghazal structure evoked spontaneity and sincerity. Almost immediately after its emergence as a spoken verse form, it came to be associated with mysticism; the ghazal is "the most opaque and elusive of Persian poetic genres. ${ }^{, 669}$ Certainly the lyrics of Hafiz offer an opportunity for creative, interpretive reading and perhaps it was their opaque quality and the ghazal's short, lyric verses that led the Persian-speaking world to turn to Hafiz as life- guide. Renaming the poet "the tongue of the unseen" (lisan al-ghayb), and comfortably at

\footnotetext{
667 Jahangirnama, p. 5.

${ }^{668}$ Ibid., 366-67.
} 
liberty to invent or interpret meaning, the Safavid, Timurid and Mughal courts commonly turned to the Divan-i Hafiz as an augury, from which they obtained predictions of the future.

An extant Diwan-i Hafiz from the Mughal library bears marginal notes in the handwriting of the emperors Humayun and Jahangir, who, in the Timurid tradition, consulted the odes and scribbled in the margins their particular reason for consulting Hafiz, as well as the results they obtained. ${ }^{670}$ The Emperor Jahangir left a record of the process; hoping for a military victory in the Deccan, Jahangir "took an augury $(f a l)$ from the divan of Khwaja Hafiz to see what the outcome would be." The emperor described the scene, "This ghazal came up:

The day of absence and the night of separation from the beloved came to an end. I took this augury, the star (omen) passed and labor came to an end.

Ruz-i hijran u shab-i farqat yar ajar shud Zadam in fal u guzasht akhtar u kar ajar shud.'

Since lisan al-ghayb Khwaja Hafiz had so spoken, I felt completely hopeful. Twentyfive days later the news of victorious triumph (fath u firuz) came." The emperor confirmed, "I have returned to the divan of Hafiz on many an occasion and, considering the successes that came from him, the results agreed exactly. Rarely has there been disagreement., 671

In addition to their reliance on his verses as oracles, the Timurid- Mughals may have been attracted by the easy licentiousness which is evoked and excused in the Divan-

\footnotetext{
${ }^{669}$ Julie Scott Meisami, Court Poetry, pp. 238-9. The ghazal is considered to have begun as sung verse, hence the short and spontaneous flow of the lyrics.

${ }^{670}$ Sh. Abdul Aziz, The Imperial Library of the Mughals, Delhi: Idarah-i Adabiyat-i Delli 1974, p. 34.

${ }^{671}$ Jahangirnama, p. 217. Thackston, tr., p. 222.
} 
i Hafiz, particularly in the context of their dynastic history of addiction to intoxicants.

The short, lyrical verses of the ghazal, the favored poetic genre of Hafiz, had early on become closely associated with the subjects of love and wine. ${ }^{672}$ Easily adopted and transformed by the Sufi poets of the medieval period into allegorical forms, the ghazal imagery of eroticism and intoxication reflect spiritual transcendence, "divine love." With Hafiz, however, whose personal religious allegiance and status as a Sufi are unclear, ${ }^{673}$ it is particularly difficult to untangle the metaphysical from the rational, to turn from the profane to the symbolic. While clearly expressing the poet's spiritual yearning, the verses of the Divan-i Hafiz lack the obvious religious clarity of such Sufi poets as Rumi. At times, Hafiz can be read to describe and support a bawdy life in which alcohol plays a dominant role.

Earlier analysis presumed an allegorical or mystical symbolism embedded within the verses of Hafiz, yet modern scholars have begun to argue that the ghazal form may, to the contrary, require a more obvious, literal interpretation. More specifically, it has been suggested that when Hafiz employed mystical imagery, "he did so mainly in order to give a mystical flavor to the whole and, by means of an explanation projected into mysticism, to gain an opportunity of escaping blame for his antimonies and blasphemy...."674

\footnotetext{
${ }^{672}$ A.J. Arberry, Fifty Poems of Hafiz, p. 25 and 28.

${ }^{673} \mathrm{He}$ is not known to have belonged to any particular mystical order.

${ }^{674}$ Jan Rypka, History of Iranian Literature, Dordrecht: D. Reidel, 1968, pp. 267-68, cited in Meisami, Court Poetry, p. 280. There is of course continuing debate as to whether Hafiz was a mystical or political court poet, whose work should be read as "a text whose difficult code its ideally expected reader experiences by decoding, and a text whose complex use of convention intends for its ideally expected reader a refined and even mannerist but immediately intelligible experience.” Judson Boyce Allen, "Grammar, Poetic Form and the Lyric Ego," Vernacular Poets in the Middle Ages, Lois Ebin, ed., pp. 199226, Studies in Medieval Culture 16, Kalamazoo, MI: Western Michigan University Institute for Medieval Studies, 1984, p. 202, as quoted in Meisami, Court Poetry, p. 280. Meisami argues for the latter interpretation.
} 
His verses do suggest a quite literal personal acquaintanceship with wine. "O minstrel, please compose a sweet melody in Persian that I can sing," Hafiz wrote, "The sound of the harp and the saqi's (winebearer) clapping have brought back sweet memories of my youth. And give some wine to my friends so that they can be happy too! Saqi, come here and bring me a quart of wine. God would not want me drinking from this little cup." 675 On another occasion, "I'm not saying you should drink all year long; for nine months on the wagon and then for three months you can be a drunk.... Be a friend of wine before you go out doing good. ${ }^{, 676}$ Whether or not this was the author's intent, the Timurid- Mughal kings were quite willing to read Hafiz in the most literal sense, and reference to the verses of this liberal poet was employed to support and defend even the most audacious of misbehaviors.

Babur's memoirs are rife with references to parties in which the Mughal founder describes drinking and drug taking to the point of physical collapse and the generous use of intoxicants seem to have been a critical component of the Timurid majlis. ${ }^{677}$ Babur's lack of inhibition in describing his drunken escapades can perhaps be better understood in the context of his heavy-drinking ancestors. Timur's court had been known for the vast quantities of alcohol consumed, as described by the Portuguese ambassador in Samarqand: "It is the custom with the Tartars to drink their wine before eating, and they are want to partake of it so copiously and quaffing it at such frequent intervals that the men soon get very drunk. No feast we were told is considered a real festival unless the

\footnotetext{
${ }^{675}$ Hafiz, Drunk on the Wine of the Beloved, p. 5.

${ }^{676}$ Ibid., p. 90.

${ }^{677}$ For a fascinating discussion of early modern Iranian drug and alcohol usage, see the new monograph by Rudolph P. Matthee, The Pursuit of Pleasure: Drugs and Stimulants in Iranian History, 1500-1900, Princeton, NJ: Princeton University Press, 2005.
} 
guests have drunk themselves sot.... And further he who refuses to drink must be made to drink, and this whether he will or no." ${ }^{978}$ A history of the Timurids describes the drinking of Timur's grandson Mirza Pir Muhammad ibn Jahangir, whose aspirations to power were destroyed because "he spent most of his time quaffing fire- colored liquid and listening to the sound of the lute and harp. The enchanting voice of the harp told of the passing of his rule...." ${ }^{679}$ Husayn Bayqara's contemporary, the Mongol Sultan Sa'id Khan, had for the sake of Islam given up the use of intoxicants, but when offered a goblet of kumis, the fermented mare's milk drink of the steppes, he felt it necessary to accept the generous hospitality of his hosts. His biographer explains that he simply "expanded his religion to allow for drinking," proceeding to spend the next eight days in a drunken revel with his Mongol companions. ${ }^{680}$

Babur's father, Umar Shaykh, had been a "great drinker," his successor and eldest son, Humayun, freely admitted to opium addiction ${ }^{681}$ and, according to contemporary reports, Akbar too had been an opium user; learning of the murder of his close friend and biographer, Abu'l Fazl, Akbar "neither shaved nor used opium" in his grief. ${ }^{682}$ As a Timurid king, social life for Jahangir included the usual Timurid reverence for poetry, formal gardens, male camaraderie, and a steady diet of intoxicants. A nineteenth-century historian declared himself aghast at the vast amounts of alcohol and drugs consumed at the court of Babur's great- grandson. Referring to Jahangir's memoirs, he exclaimed, "There are as many drinking bouts noticed as in the Memoirs of Jahangir's great-

\footnotetext{
${ }^{678}$ Clavijo, Embassy, p. 231.

${ }^{679}$ Khwandamir, Habib al- Siyar, in Thackston, CP, p. 118.

${ }^{680}$ Mirza Haydar Dughlat, Tarikh, p. 179.

${ }^{681}$ Humayunnama, p. 38. Beveridge, p. 131.

${ }^{682}$ Asad Beg, Wikaya, E\&D, VI, p.155.
} 
grandfather Babur, and the extraordinary potations to which he [Jahangir] confesses would have shamed even that immoderate toper." ${ }^{683}$ Unapologetic drug use, and only slightly embarrassed alcoholism, received regular references in Jahangir's writings. In the year 1621 the emperor regretfully recorded the death of "an old and trusted servant," whose sole charge at the Mughal court seems to have been the care and keeping of the imperial intoxicants. Immediately after this servant's death Jahangir appointed a new steward for opium and another for wine. ${ }^{684}$

On the first Nauruz (the pre- Islamic Persian New Year) after his accession, Jahangir celebrated with "musicians and singers of every type.... dancing gypsies and charmers of India, who could seize the hearts of angels with their blandishments (ahal saz u nagma' az har ta'ifa... lulian-i raqas u dilbaran-i hind ki be kirishma dil az firishta mi rubudand)." He encouraged the revelers with a decree that "everyone could drink whatever intoxicants or exhilarants (makfiyat u mugirat) he wanted without prohibition or impediment (mana ${ }^{\prime}$ u mani ${ }^{\prime}$ )." As a Muslim king, anxious to support his legitimacy in public gestures of justice and ethical rule, Jahangir defended this wildly unconventional imperial proclamation by a reference to the Divan-i Hafiz, carefully quoting the poet in his memoir:

Cup bearer, brighten our goblet with the light of wine! Sing, minstrel, for the world is working as we desire.

Saqi, bi nur-i bada bar afruz jam-i ma Mutrib bigu ki kar jahan shud ba kam-i ma. ${ }^{685}$

\footnotetext{
${ }^{683}$ Comments by the editor, E\& D, VI, p. 260.

${ }^{684}$ Jahangirnama, p. 360.

${ }^{685}$ Jahangirnama, p. 29. Quote from Hafiz, Divan, 6, line 10, tr. by Thackston, p. 46.
} 
Yet for all their liberality and willingness to forgive libertine excesses, the ghazals of Hafiz, like the other texts held most dear at the Timurid- Mughal courts, reflect a general preoccupation with the ethics of kingship. Hafiz offered a running commentary on courtly behavior, emphasizing the transience of power and riches, the need for justice and social harmony. Reinforcing the Timurid- Mughal's highly developed sense of the centrality of regnal justice, Hafiz wrote, "The king will gain more from one hour of justice, than from one hundred years of worship and prayer." ${ }^{2686}$ Modern scholarship has made the connection to a broader popular engagement with these questions, writing of the ruler, as portrayed by Hafiz, "If the king is, ideally, the Perfect Man of his age, he is also, in a particular sense, Everyman, embodying the highest ideals of humanity. Combining temporal and spiritual rule, he incarnates the dual idea of justice and love expressed by Nasir al-Din Tusi and bears the responsibility for upholding and maintaining the social order of which love is the guiding force." ${ }^{\prime 67}$ And while, very much in the style of the Timurid-Mughal kings, Hafiz was willing to step well outside of the boundaries of normative Islamic law, engaging in and excusing behaviors condemned in the narrower legalist understandings, he, like Rumi and $\mathrm{Sa}^{\circ} \mathrm{di}$, carefully presented a fundamentally Muslim identity, positioning his ethical imprecations in an Islamic context, writing "I have seen no verses sweeter than yours, Hafiz, [I swear] by that Quran you hold in your breast." ${ }^{688}$

\footnotetext{
${ }^{686}$ Haleh Pourafzal and Roger Montgomery, The Spiritual Wisdom of Hafiz, Rochester, Vermont: The Spiritual Traditions, 1998, p. 201.

${ }^{687}$ Meisami, Court Poetry, p. 297.
} 


\section{Indigenous Literature and the Mughal Translation Movement}

Yet while the origins and heart of the Mughal library lay in the literary collections of the empire's first rulers, as the empire gained in power and influence the imperial library expanded to include a much more varied collection of manuscripts. Many of these texts could not have been known to the Timurids in Transoxiana, and certainly could be seen to constitute a threat to the original political and ethical constructs reflected in Timurid literary preferences. With a much broader selection of materials to draw from, the question becomes how the increasingly diverse manuscripts owned and read by these literary emperors and their families affected their loyalty to the Timurid literary-ethical canon, represented by the works of Nasir al-Din Tusi and the great Persian poets, Rumi, Hafiz and Sa di. An examination of the maturing Mughal library exposes clear trends in the religious and political thinking of Mughal emperors, while confirming their unwavering reliance on the core texts which supported and defended their very particularly Timurid moral and ethical structures.

Abu'l Fazl described the imperial library, which by Akbar's death had grown to include 24, 000 volumes, sub- divided based on value and content, with Hindi, Persian, Greek, Kashmiri and Arabic works organized in separate categories. ${ }^{69}$ It is clear that Mughal political culture was in close contact with indigenous Indian literature, and Akbar's acknowledged spiritual and cultural curiosity is well illustrated by the increasingly diverse contents of the Mughal library. Under Akbar the literary tastes of the Mughals expanded to include not only Arabic and Greek but, additionally, the Hindu classics. In an ambitious translation project, Akbar demanded that ancient Hindu literary

\footnotetext{
${ }^{688}$ Ibid., p. 297.
} 
works, such as the Mahabharata, the Ramayana and various Hindu Vedas, as well as local histories and romances, be translated into Persian from Sanskrit. Abu'l Fazl confirmed that at Akbar's court "Philologists are constantly engaged in translating Hindi, Greek, Arabic and Persian books into other languages." ${ }^{, 690}$ The Mahabharata was translated into nearly 100, 000 verses in Persian, and named the Razmnama, the Book of Wars, by a committee of learned men at Akbar's court: Abd al-Qadir Badauni, Mulla Shari, Naqib Khan, Shaykh Sultan Haji of Thenesar, and Shaykh Fayzi, Abu'l Fazl's poet- brother who wrote the foreword to the finished piece. ${ }^{691}$ The Ramayana was also translated by this group, over a four-year period, and finished in 1589. Abu'l Fazl lists additional translations from Sanskrit completed in Akbar's ateliers, including the Atharbana (the fourth Veda), Lilawati (a work on arithmetic, described by Abu'l Fazl as "one of the most excellent works written by Indian mathematicians, [which] lost its Hindu veil and received Persian garb"), Tajak (a study of astronomy, translated by Muhammad Khan of Gujarat), the Haribas, a life of Krishna, the History of Kashmir (translated from Kashmiri by Mawlana Shah Muhammad of Shahabad and then again translated, into simpler terms, by Badauni, over two months). ${ }^{692}$ Other translations include the Sanghasan Battisi, a set of thirty- two stories by Raja Bikramjit, ruler of Malwa, finished in either 1574 or $1581 .{ }^{693}$ The Nahl Daman was a Hindi love story, translated by Abu'l Fazl's brother into the very same masnawi metre as the classic

\footnotetext{
${ }^{689}$ AA, I, p. 110.

${ }^{690}$ Ibid. Also, see Badauni, Tawarikh, II, p. 216, pp. 329- 31 and pp. 346- 48.

${ }^{691}$ Badauni, Tawarikh, II, p. 329.

${ }^{692}$ Abu'l Fazl, AA, III, pp 109- 112.

${ }^{693}$ Badauni, Tawarikh, II, p. 204.
} 
Persian love story of Leyla and Majnun, which it resembles. ${ }^{694}$ Bahru'l-Asmar was the name given to a Persian translation of a Hindi romance, translated for the Mughal court by order of Sultan Zayn al-Abidan, the king of Kashmir. ${ }^{695}$ The Jog Bahisht was translated into Persian from Sanskrit, illustrated with forty- one miniatures, and placed in the Mughal library; an extant copy contains notations by Jahangir and Shah Jahan. ${ }^{696}$

There were loudly voiced complaints and at times openly reluctant acquiescence by the conservative bilingual Muslims at court who were ordered by the emperor to participate in the translation of indigenous classics. The Hanafi legalist Abd al-Qader Badauni, ordered by Akbar to assist in the enormous translation project, expressed resentment and at one point lost his stipend because the historical account of Raja Bikramijit, ruler of Malwa, which he had been ordered to translate, disappeared entirely, seemingly stolen, from the Mughal imperial library. In the face of his earlier objections, he was considered the most likely culprit. ${ }^{697}$ Badauni's outrage was expressed in a secret memoir in which he describes the Hindu texts as "puerile absurdities." 698 "We flee to God," he wrote, "for refuge from infidelities and unprofitable words!"699 Yet undeterred by criticism and obstreperous courtiers, the translation movement inexorably continued, and Akbar went on to have the Mahabharata and the Ramayana illustrated. ${ }^{700}$

It was not only Hindu works which threatened the Islamic hegemony longed for by Muslim conservatives such as Badauni and his ilk. At the request of the emperors

\footnotetext{
${ }^{694}$ Abu'l Fazl, AA, p. 112-3.

${ }^{695}$ Badauni, Tawarikh, II, p. 384. It is conjectured that this was originally entitled the Rajatarangini. See Abdul Aziz, Library, p. 49.

${ }^{696}$ Abdul Aziz, Library, p. 50.

${ }^{697}$ Ibid., p. 49.

${ }^{698}$ Badauni, Tawarikh, II, p. 330.

${ }^{699}$ Ibid., p. 331.

${ }^{700}$ Ibid., p. 30.
} 
Akbar and Jahangir, a Portuguese Jesuit missionary residing at the Mughal court in Agra, Jerome Xavier, composed the Mi'rat al-Quds, a life of Christ based on the New Testament; the Dastan-i ahwal-i Hawariyan, a description of the lives of the apostles; the Zabur, a translation of the Psalms of David; the 'Ayn-i haqqnama and its abridgment, the Muntakhab-i 'Ayn-i haqqnama; and the Adab al-sultanat, all three of which dealt with the doctrines of Christianity. ${ }^{701}$ These Christian religious studies were translated into Persian by the author and Abd al-Sattar ibn Qasim, a Mughal courtier who had been ordered by Akbar to learn Portuguese in order to translate European manuscripts into Persian. ${ }^{702}$ Mughal interest in non- Muslim works was not simply a product of Akbar's own heterodoxy. In the reign of Shah Jahan, Sanskrit classics were still being translated into Persian at the Mughal court, including the Salotari, which had come to the Mughal court from the library of Rana Amar Singh of Chitaur, and was translated by Sayyid Abdullah Khan Bahadur Firuz Jang. ${ }^{703}$ In the Mughal spirit of mutual cultural sharing, imperial translations occasionally included manuscripts which were translated from Persian into Hindi, including works of mathematics and astronomy. In 1630, Shah Jahan had new astrological tables devised which replaced, for the first time, the classical charts of Timur's astrologer grandson, Ulugh Beg. The emperor ordered that Indian and Greek astronomers work together to translate the new charts into "the various languages of India so as to make them accessible to all classes." ${ }^{, 704}$ A quite late translation, the Parijataka,

\footnotetext{
${ }^{701}$ Marshall, Bibliography, p. 490.

${ }^{702}$ Ibid., p. 26.

${ }^{703}$ Ibid., p. 54.

${ }^{704}$ Abdul Aziz, Library, p. 52. See Abd al-Hamid Lahauri, Badshahnama, Kabir al-Din Ahmad and Abdul Rahman, eds., Calcutta,1869- 74, vol. I, pp. 286-7.
} 
based on a Hindu study of music and dance, was made by a Mughal official who called himself Zamir and referred to himself as a "slave of emperor Alamgir.,"705

While yet a prince, Dara Shikuh, son of Shah Jahan and a devout Sufi of the Qadiriyyah order, writing, "Kingship is easy; make yourself familiar with the ways of asceticism" (sultanat sahal ast; khudra ashnayi fakir ki), ${ }^{706}$ translated from the original Sanskrit the Bhaghavadgita and the Yoga Vasishtha. His Persian translation of fifty verses of the Upanishads, entitled the Sirr-i Akbar, was the source from which a nineteenth-century Latin translation would be made, powerfully influencing European philosophers and Orientalists. ${ }^{707}$ Grounded in Islam, yet driven by the spiritual quest which seems to have engrossed many a Timurid- Mughal, Dara Shikuh made overt claims of Hindu- Muslim religious unity, asserting that the Upanishads were the "Hidden Books" referred to in the Qur'an. The Mughal prince wrote of himself, "Any difficult problem or sublime idea that came into his [Dara Shikuh's] mind and was not solved in spite of his best efforts, becomes clear and solved with the help of this ancient work [the Upanishads], which is undoubtedly the first heavenly Book and the fountainhead of the ocean of monotheism and in accordance with or rather an elucidation of the Quran.... They [the verses] contain the essence of unity and they are secrets which have been kept hidden., ${ }^{708}$

\footnotetext{
${ }^{705}$ Marshall, Bibliography, p. 499.

${ }^{706}$ Dara Shikuh, Bahrain, p. 19.

${ }^{707}$ Nasr, Sufi Essays, p. 141. See above, chapter five, for a full list of the works of Dara Shikuh.

${ }^{708}$ Dara Shikuh, Bahrain, p. 13, and Upanishads, ed. by Tara Chand and J. Na'ini, Tehran: Sirr-i Akbar, 1957-60, introduction.
} 
His argument for religious unity ${ }^{709}$ became a weapon to be wielded against him by his brother Aurangzeb when, victorious in the war of succession, Aurangzeb declared Dara Shikuh a heretic and had him summarily executed. Dara's Sirr-i Akbar included many verses which had otherwise remained unrecorded, and in the eighteenth and nineteenth centuries Hindu scholars came to describe Dara's work as an important factor in the preservation of Hindu doctrine. In the nineteenth century the Mughal prince Dara Shikuh, who styled himself Hanafi Qadiri and thus illustrated his absolute loyalties to Islam and Islamic mysticism, was declared to have been one of the "revivers of Hinduism. ${ }^{, 710}$

The list of favored books in the Mughal library, while it affirms the dynasty's religious loyalty, not surprisingly, supports the perception that most Mughal kings retained a casual approach to religion and were not terribly interested in Quranic exegesis or law, although such works without question were offered a place on the shelves. On the death of Akbar's court poet, Abu'l Fazl's brother Fayzi, his library of four thousand manuscripts was placed in the larger imperial Mughal library and classified by merit, in categories of superior, middling and inferior. Those judged superior were works of poetry, medicine, astrology and music. Middling books included philosophy, tasawwuf (Sufism) and astronomy. The least valued were works of tafsir (exegisis), hadith (tradition), fiqh and sacred law! $!^{711}$ The religiously conservative emperor Aurangzeb

\footnotetext{
${ }^{709}$ It is interesting to note that unlike Akbar, who attempted to construct a new synthesis of world religions, Dara Shikuh remained steadfastly Muslim, declaring the Upanishads to be sacred texts within the Islamic tradition.

${ }^{710}$ Nasr, Sufi Essays, p. 141.

${ }^{711}$ Abdul Aziz, Library, p. 57. It is unclear in the sources just who determined the ranking of these works.
} 
seems an exception to the Mughal pattern of religious toleration, yet surely he no less than Akbar displayed that passionate spiritual yearning common to members of the Timurid- Mughal dynasty. Aurangzeb is known to have collected tafsir, hadith and fiqh, yet left his handwriting in the margins of the Mughal library's Diwan-i Hafiz and Shahnama manuscripts, the latter of which had been signed by all of the Mughal emperors from Babur to Aurangzeb. ${ }^{712}$

The imperial library of the Mughals reflects intellectual shifts in the interests of the various emperors, yet illustrates the degree to which the Mughal dynasty as a whole remained relentlessly loyal to the personal and political values of their ancestors in Central Asia. With such a library available to him, the tastes of even the famously heterodox Akbar were reflected in the texts he chose to have read aloud to him daily: the Akhlaq-i Nasiri, Sa di’s Gulistan, Rumi’s Masnawi (which Akbar is said to have memorized), Firdowsi's Shahnama and various works of local and family history. ${ }^{713}$ Shah Jahan is said to have particularly favored ancestral memoirs, having the Baburnama and Timur's Zafarnama read aloud to him in the evenings. ${ }^{714}$

While the bibliophile Mughals celebrated each conquest which brought with it as booty an imperial library, the Mughal family affirmed its loyalty to those particular texts held most dear by their dynastic founder Babur and his predecessors. Those texts which had been of central importance in the political- ethical understandings of Timurid Transoxiana retained their influence in the development of Mughal political culture and

\footnotetext{
712 Ibid., p. 31.

${ }^{713}$ Ibid., p. 34.

${ }^{714}$ Inayat Khan, Shah Jahan Nama, p. 573.
} 
remained of central importance in the context of Mughal India. Their influence came to be acknowledged and absorbed by not solely the Persian and Turkic Central Asian individuals associated with the royal dynasty, nor even exclusively the Muslim members of the aristocracy, but by the entire imperial Mughal court. As late as the reign of Shah Jahan, the Hindu court poet Chandra Bahan Brahman asserted that it was this selection of texts-- Nasir al-Din Tusi's Akhlaq-i Nasiri, a respected later interpretation of it, the Akhlaq-i Jalali, by Jalal al-Din Davvani and the Gulistan and Bustan of Sa di-- which defined the Mughal cultural code. It was through an awareness and understanding of this literature, he wrote in a letter of advice to his son, that young men could "earn their capital, and be blessed with the fortunes of knowledge and good moral conduct.",715

\section{The Yasa of Chingiz Khan}

Even after intimate contact with indigenous literature, and the many literary accretions and modifications of the Mughal library, Mughal religious and political ethics remained fundamentally loyal to the basic tenets and moral standards of their ancestors. This included an allegiance to pre- Timurid, even pre- Islamic, aspects of their inherited Turco- Mongol culture.

Timur was said to have "clung to the laws of Jenghizkhan [sic]... and he observed them in preference to the law of Islam." Even those of his descendants noted for their religious conservatism were accused of loyalty to the ancestral canon of tradition. "It is said however,” wrote Timur's biographer, “that Shahrukh [Timur's successor] repealed the laws and customs of Jenghizkhan [sic] and ordained that they should make his rule

\footnotetext{
${ }^{715}$ Muzaffar Alam, "State Building," p. 116.
} 
flow along the stream of the law of Islam, but this I do not consider true, since it is considered among them [the Timurids] as the purest religion and true faith and if it happened that [Shahrukh] should summon his chief men and doctors to his palace... and look upon them from his throne and propose to them anything of this sort, truly they would flee like asses to the gates!",716 The author of the Akhlaq-i Nasiri, Nasir al Din Tusi, referred in his writings to "the Great Yasa (yasa-yi buzurg) of Chingiz Khan," although without offering specific details regarding its content. ${ }^{717}$ As late as the reigns of Jahangir and Shah Jahan, imperial chronicles contain regular references to Mughal loyalty to Mongol law, the yasa and tamgha of Chingiz Khan.

While later generations may have understood the yasa of Chingiz Khan as a binding legal code, there seem to have existed no official text articulating specific ancestral laws. It has been cogently argued that the codification of a coherent body of law by Chingiz Khan in the early thirteenth century was more imagined than real, its content representing ancient Mongol custom rather than kanun. ${ }^{718}$ The Persian chronicler of the Mongols, Ala al-Din Ata al-Juwayni, uses the term yasa to describe regulations and decrees (qawa'id u yasaha and ahkam u yasaha), rather than a clearly identified code of law. ${ }^{719}$ Yet as early as the period of the Ilkhanate "the Yasa remained, apparently, in the Mongol consciousness as a symbol of the Shamanist, primitive, simple and perhaps (to some) 'purer' past, which had gradually been eroded by conquest and world

\footnotetext{
${ }^{716}$ Ibn Arabshah, Tamerlane, p. 299.

${ }^{717}$ David O. Morgan, "The 'Great "yasa" of Chingiz Khan' and Mongol Law in the Ilkhanate," Bulletin of Oriental and African Studies, In Honor of Ann Lambton, v. 49:1 (1986) p. 169.

718 Ibid.,.

${ }^{719}$ Juwayni, Tarikh-i Juhan Gusha, ed. M.M. Qazvini, 3 vols, Leiden and London, 1912, 1916, 1937; trans., J.A. Boyle, The History of the World Conqueror, 2 vols., Manchester, 1958. As in Morgan,"Yasa," p. 168.
} 
empire. ${ }^{, 720}$ Babur himself seems to confirm its amorphous qualities in writing, "Chingiz Khan's code is not a binding text according to which a person must act absolutely.",721

Perhaps due to the "imagined" character of its legal standards and ethos, the Chingizid Yasa offered the Timurids and Mughal court support for royal sensibilities and standards already in place that would otherwise have been on weak ground within a narrower understanding of the orthodox Islamic tradition. Juwayni claimed that the Yasa required a ruler to "consider all sects as one and not distinguish one from another." Chingiz Khan, he asserted, had "eschewed bigotry and preference of one faith over another, placing some above others." ${ }^{, 722}$ In relying on these ethical and legal traditions of their ancestors, the Mughal kings unapologetically asserted a legitimate defense of their state policy of religious harmony, particularly in the face of criticism by the likes of the Naqshbandi Shaykh Sirhindi, or Akbar's conservative Sunni biographer, al-Badauni. The ulama at the courts of the Timurid-Mughals protested to little avail, for even after the Islamization of the western Mongols and Turks had become well entrenched, their continued loyalty to Chingizid tradition could trump that of their Islamic identity, and was particularly useful if that loyalty was couched in references to a universally admired yet carefully vague body of traditional family law.

In much the same spirit, and for many of the same reasons, the Mughal emperors seem to have had no more qualms or concerns over the awkward reconciliation of Islamic and Mongol legal systems than had their illustrious ancestors. Jahangir describes

\footnotetext{
${ }^{720}$ Ibid., p.173.

${ }^{721}$ Baburnama, Mano, p. 291. Thackston, p. 391. Also, Morgan, "Yasa,” p. 168.

${ }^{722}$ Juwayni, Tarikh-i Jahangusha, Mirza Muhammad, ed., London, 1912, I, pp. 18-9, cited in Iqtidar Alam Khan, "Akbar's Personality Traits and World Outlook - A Critical Reappraisal," in Irfan Habib, ed., Akbar and His Age, New Delhi, 1997, p. 81.
} 
punishments at his court ba rasm-i u tura-i Chingiz Khan, "by the custom and law of Chingiz Khan," and while there is little reason to believe that any particular body of canonized Mongol law was regularly applied in Mughal India, it is clear that Jahangir felt it important to articulate his own respectful allegiance to Chingizid tradition, affirming its place in the Mughal court, while steadfastly remaining silent as to his own attendance at the Friday mosque. ${ }^{723}$ In India, as in Central Asia and Iran, "if the 'Great Yasa of Chingiz Khan' did not exist it was evidently necessary to invent it.",724

As we have seen, in their own self- conscious presentation of self and empire, the Mughals put a great deal of effort into affirming their legitimate role as Islamic kings on the medieval Persian model described by Nasir al-Din Tusi, Rumi, Hafiz and Sa'di. Yet their Central Asian Turco-Mongol dynastic lineage remained a central component of Mughal imperial identity on the subcontinent. The religious and ethical construct of the Mughal kings, in other words, continued to closely resemble that syncretic stew created by their late Timurid ancestors, and remained above all pragmatic, informal and statist. Offering public allegiance to the Timurid model of imperial tolerance and the careful adherence to justice, the ethical loyalties of the Mughals offered them political and religious legitimacy and a pragmatic model for kingship.

Mughal casual religious pragmatism may be attributed less to their position on the periphery of the Islamic heartland or to influences from the Indian environment than to Mughal retention of late Timurid ethical and political values, which had been built on a deeply felt allegiance to Islam as filtered through both the medieval Persian literature of political philosophy and ethics and a heavily mythologized yet entirely practical

\footnotetext{
${ }^{723}$ Jahangirnama, p. 40.
} 
understanding of traditional dynastic (that is, Mongol) law. Almost entirely drawn from medieval Persian poetry and prose, the literature which best encompassed the Timurid vision was already universally admired throughout the Islamic world, tying the Mughals and their successors intellectually and aesthetically to their Muslim contemporaries in Anatolia and Iran, and was a ubiquitous presence in the Timurid Central Asian milieu. This was the literary material with which the Timurids were most intimately familiar and it was the most highly prized, forming the heart of their imperial libraries for generations. The set of moral, political and aesthetic understandings which it embodied, carried to the subcontinent by the Timurid refugees, the bridge between the late Timurid milieu of Transoxiana and the new Mughal courts of Delhi and Agra, represented a literary canon, the presence of which may explain the highly resistant Timurid character of Mughal political and cultural ethics.

Combined, these works represent the culmination of a social ideology that became a critical common reference point for the Timurid-Mughals, defining and articulating a Timurid vision of human relations, ethics, justice and kingship. We can confidently assert that that the true obsession of the Mughals lay less in religion than in lineage; it was their Timurid dynastic heritage-- including a model of ethics and kingship within which they could find comfortable accommodation-- that remained of central importance to their understanding of imperial identity and empire.

${ }^{724}$ Morgan, “Yasa,"p. 173. 


\section{CHAPTER 7 \\ CONCLUSION \\ THE TIMURIDS OF INDIA}

It is difficult to overemphasize the power and influence which, by the middle of the fifteenth century, had accrued to the Timurid lineage and cultural personality. Out of the political fragmentation of post- Mongol Central Asia the raider and steppe warrior Timur had forged a new empire in which the two local sources of power and legitimacy, the legacy of Chingiz Khan and allegiance to Islam, were artfully bound into a single Timurid model of legitimation. Deeply sensitive to the potency of Chingizid and Islamic symbols, Timur actively participated, through overtly violent acts of military and political theatre and an equally performative royal court culture, in the fabrication of an imperial public image. With what seems a remarkable degree of self- awareness, Timur orchestrated the construction of so sound a political identity that legitimacy henceforth became an attribute of his particular lineage and his court a model for imperial culture.

In the wake of his death, in the highly competitive and fragmented environment of fifteenth-century Central Asia, Timur's successors followed their ancestor's strategy. Their privileging of the artistic forms of Perso-Islamic high culture, and the unprecedented degree of artistic patronage at rival Timurid princely courts, produced a Timurid cultural efflorescence. The emphasis on literary and artistic patronage was so profound, and cultural and aesthetic understandings so highly developed, that Timurid 
princely courts came to represent the enviable apex of royal court culture across the Islamic world. As we have already seen, contemporary Muslim dynasties such as the Ottomans, Safavids and Uzbeks expressed admiration for the Timurid courts of Mawarannahr, attempting to attach their own political legitimacy to a Timurid lineage while their courtiers encouraged imitation of the royal culture of the Timurid princes. In India, the Muslim sultan of the Hindu Bahmani kingdom of the Deccan, Firuz (13971422), deeply impressed by Timur's sack of Delhi, sent ambassadors to Timur's court in Samarqand to offer homage, although his own kingdom had not been threatened by the Central Asian warriors, lying as it did far south of Timurid conquest territories. Timur graciously accepted his fealty, sent gifts, and offered Firuz the rulership of Gujarat and Malwa, although neither ruler had yet conquered those regions. ${ }^{725}$ "Fancying himself playing on a larger geo- political stage than had his ancestors," Firuz actively recruited "Iranians or Persianized men of talent" to his Deccani court in an attempt to emulate the style of the Timurid courts. ${ }^{726}$

So influential had the Timurid imperial model come to be that even non- Muslim royal courts were aware of the reputation and sough to emulate it, in much the same manner as their better known Muslim contemporaries. A fifteenth-century member of the Timurid court elite visited the southern state of Vijayanagar, noting that its Hindu kings had begun to title themselves "sultan" (assimilated into Sanskrit as suratrana) and sat enthroned in a chihil sultan, a multi- columned Persianate hall inspired by Persepolis, rather than by traditional Hindu palace architecture based on the mandala design. The

\footnotetext{
${ }^{725}$ Richard Eaton, A Social History of The Deccan, 1300- 1761, Cambridge: Cambridge University Press, 2005 , p. 51.

${ }^{726}$ Ibid., p. 61.
} 
visitor was "closely questioned about... Samarqand, Harat and Shiraz" by the king Deva Raya II (1424- 46), and noted "an awareness of, and avid interest in, the Timurid court. ${ }^{, 727}$ By the time of the Mughal conquest of northern India, the Timurid cultural personality was the unrivaled ideal on the subcontinent, and the lineage of Timur had developed a profound charisma.

The Uzbek confederation's conquest of Mawarannahr was absolute and, having fled to India, the Timurid-Mughals would never again see their ancestral capitals of Samarqand and Harat. Although successfully transplanted to a wealthier, larger territory, the violently displaced Timurid elite and their descendants shared a sense of enormous loss; Babur described his condition as "exile." As identified in contemporary studies of refugee identity, the Timurid exiles' sense of loss resulted in a heightened need for communal identity and social bonding. Those who had survived the Uzbek invasion and managed to make their way to India were deeply aware of the cultural and political power of the Timurid legacy they had inherited and, in the bitterness of exile, they remained devoted to developing and maintaining a set of shared Timurid symbols and ideals. Mobilized to construct an imperial identity which could justify, sustain and support their overwhelming imperial success in India, they managed to impose an explication of dynastic identity and political legitimacy in India which was modeled almost entirely on the universally acclaimed attributes of their Timurid predecessors. As this study has illustrated, the Timurids made a deliberate effort to "remember" and to privilege components of the communal identity which would serve to unite, legitimize and sustain them: charismatic ancestry and systems of political power, language, family

${ }^{727}$ See Abdul al-Razzaq Samarqandi, "Mission to Calicut and Vijayanagar," in Thackston, CP, p. 308. 
relationships, inheritance and succession, aesthetic and literary understandings, religious identity, morality and ethics. Resounding imperial success apart, their forcible migration remained the central, defining event of the Timurid- Mughal community, inspiring regular efforts to affirm ancestral, cultural, ideological and territorial links.

This process, in the context of their well-renowned Timurid charisma, resulted in a remarkably broad acceptance of the Timurid-Mughal model of kingship. So successfully did they manage to transfer the political and cultural charisma of their dynastic lineage from their place of origin in Transoxiana to the Indian subcontinent that it was sufficient to support their imperial project for over three hundred years, in the farflung regions to which they had arrived as near strangers. So soundly constructed was the Timurid- Mughal imperium that subsequent successor states and colonial powers continued to deploy Mughal symbols of power and legitimacy in order to prop up their own political aspirations, long after the last of the Mughal dynasts living in poverty and powerlessness in the crumbling palaces of Delhi had lost their ability to govern.

Even at the popular level, Mughal imperial charisma became so deeply entrenched that as late as the nineteenth century, Akbari coins were believed to have medicinal properties; a woman in childbirth could ease her pains by drinking water "in which ... a rupee of Akbar's time has been washed." ${ }^{728}$ In the collapse of Mughal power in the wake of mid- eighteenth century opposition movements and invasions, there was near universal agreement among those in power "regarding the divine right of the

Eaton, p. 101.

${ }^{728}$ R.V. Russell, Tribes and Castes of the Central Provinces of India, 4 vols., London, 1916, II. 'Kunbi,” p. 29. Cited in John Richards, "The Formulation of Imperial Authority Under Akbar and Jahangir," The Mughal State, 1526- 1750, Muzaffar Alam and Sanjay Subrahmanyam, eds., New Delhi: Oxford University Press, 1998, p. 153. 
Timurids to rule," and as late as the reign of the last Mughal king, Bahadur Shah II Zafar (d. 1862), hope was expressed in India's governing circles that an imperial revival could be constructed under the charismatic leadership of a Timurid descendant in order to unite the crumbling empire. ${ }^{729}$ When, in 1857 , sepoys serving in the province of Meerut rose in rebellion against British rule, they turned to the aged inhabitant of the crumbling Red Fort in Delhi to "seek out the higher authority of the Mughal emperor." ${ }^{, 30}$ In requesting the sanction of the last Mughal king, the sepoys, who were themselves too young to have had personal experience with Mughal rule, which by that time had become limited to Delhi and its immediate periphery, managed to turn what had begun as a spontaneous local insurgency, into "a political revolt whose legitimacy arguably transcended that of the regime it challenged." ${ }^{, 731}$ In the aftermath of the failed uprising, just prior to his capture and exile to Burma, the last emperor affirmed the centrality of the Timurid lineage to both his personal and imperial identity. "Now it seems that I and my line are destined to be ruined," he said. "The name of the Timurid Emperors is still alive, but soon that name will be destroyed and forgotten." 732 "Now there is not a shadow of a doubt that of the great House of Timur I am the last to be seated in the throne of India. The lamp of Mughal domination is fast burning out." ${ }^{, 733}$ The British rulers of India rejected requests by his few remaining descendants to construct an imperial tomb for the

\footnotetext{
${ }^{729}$ Satish Chandra, Parties and Politics at the Mughal Court, p. 257.

${ }^{730}$ John Keay, India, A History, New York, NY: Grove Press, 2000, p. 438-9. Bahadur Shah II Zafar was eighty years old when the sepoy rebellion began.

${ }^{731}$ Ibid., Keay points out that the events of 1857 have been variously described by the British as "The Sepoy/ Bengal/ Indian Mutiny" and by Indians as "The national uprising" and "The first War of Independence." His suggestion of "The Great Rebellion" seems to approach an appropriate balance.

${ }^{732}$ William Dalrymple, Last Mughal, p. 278.

${ }^{733}$ Ibid., p. 342.
} 
last Timurid king, in part, it was admitted, to avoid the shrine's emergence as a centerpiece of continued revanchist nostalgia and political unrest. ${ }^{734}$

\section{Adaptation and change}

Yet while the Mughals obsessed over the retention of their ancestral identity and values, over the centuries of their rule in India a degree of dynastic adaptation gradually occurred. When the Central Asian prince Babur first conquered northern India, he complained bitterly about the Indian climate and culture, the lack of melons and of madrasas, but over one hundred years later, when the Mughal emperor Shah Jahan sent armies north to reconquer Balkh and Badakhshan, the "hereditary territories of his house, and... the keys to the acquisition of Samarqand, the home and capital of his great ancestor, Timur Sahib Qiran, ${ }^{, 735}$ his son, Murad Baksh, quickly fled the newly conquered city of Balkh, returning to India in disgrace. In a telling commentary on the adaptation of the Timurid- Mughals to their subcontinental empire, when the outraged emperor demanded to know for what reason his son had deserted the Mughal army, the prince replied that he could not bear the cold; he and his nobles "were dreading the hardship of passing a winter in that clime.",736 It was "a natural love of home," added the commentator, "a preference for the ways of Hindustan, a dislike of the people of Balkh, and the rigors of the climate." ${ }^{, 737}$ Although the reconquest of Samarqand remained an evocative dream and the Mughal emperors continued to cling to their charismatic lineage, it is clear that by the middle of the seventeenth century, when Shah Jahan had his palace

\footnotetext{
${ }^{734}$ Asher, “Architecture," p. 225.

${ }^{735}$ Abdul Hamid Lahauri, Badshahnama, E\&D, VII, p. 70.

${ }^{736}$ Inayat Khan, Shah Jahan Nama, p. 356.

${ }^{737}$ Abdul Hamid Lahauri, Badshahnama, E\&D, VII, p. 71.
} 
walls inscribed with the verses of Amir Khusraw, "If there is Paradise on earth, this is it!," the Mughals had adapted to South Asia. Timurid steppe culture no longer represented the whole of their imperial identity but rather a component of a greater Mughal- Indian synthesis.

Since the reign of Akbar Mughal kings had been born of Rajput mothers and raised in palaces housing Hindu temples. ${ }^{738}$ When they hunted it was as often on elephants as on ponies, and although Jahangir defensively asserted his own fluency in the Chaghatay Turkish of his Timurid ancestors his memoir, unlike that of his great grandfather, was composed in the court Persian of Timurid India and sprinkled with Hindi vocabulary. It seems very likely that he, along with the rest of his family, had some degree of proficiency in that language, particularly in light of his regular mention of private religious debates with Hindu "yogis and pundits." Not incidentally, Jahangir used his memoirs to constantly assert and publicly affirm the enormous wealth and power the kingship of India had brought his dynastic line. In contrast to their contemporaries, the Ottoman sultan, the Safavid Shah, and the Uzbek and Afghan Khans, as well as their own ancestors in Central Asia, the Mughal kings controlled immeasurable wealth, derived from the taxation of one of the world's largest populations, ${ }^{739}$ as well as from India's carefully protected and highly profitable export trade. Jahangir's memoir includes plentiful lengthy and painstaking descriptions of the valuables presented at court, where regular public gift exchanges tied the nobility to the throne; all of the goods are carefully

\footnotetext{
${ }^{738}$ This trend continued, long after the reign of the conservative Muslim Aurangzeb, to the end of the dynasty. Like so many of his predecessors, Bahadur Shah II Zafar (d. 1862) had a Hindu mother.

${ }^{739}$ It is estimated that the population of Mughal India at the peak of Mughal power may have reached 80 to 100 million.
} 
evaluated in both Indian and Persian measures so that the reader might have no doubt of the value.

Beyond their incomparable wealth, their easy Mughal adoption of Hindu wives, Hindi phrases, hunting elephants, South Asian foods, and the occasional Indian architectural motif, in some cases Mughal acts of kingship meshed pre-existing Timurid court structures with local South Asian ruling traditions. In acting out those public performances of kingship which merged South and Central Asian understandings of rule, the Mughals could affirm legitimacy and thereby find a measure of acceptance in their new imperial context, not only within their own eclectic court circles but perhaps even among the larger subject population.

For example, the relative independence of Turco- Mongol warriors and their retinues had required rulers to regularly renegotiate claims of loyalty and obedience in Central Asia's princely courts, through intimate and easy contact. Relationships were informal and familiar, and access to the ruler was generally easy and open, even long after the opportunity for a formal ritualized court system had emerged in the imperial courts of post- Timur Transoxiana. As for the Mughal founders, Babur and Humayun had shared camp life with their followers, mingling easily with their loose and amorphous retinue. Yet the later Mughal kings, emperors of enormous territories, maintained an increasingly formal imperial court at which not all members of the royal retinue shared, understood or supported the Turco- Mongol traditions of the ruling family. The dynasty was forced, thereby, to formalize a system of interpersonal interaction. It is in this context that the Mughal's adoption of the Hindu court tradition of the jharoka-i darshan, balcony of viewing, with its origins in ancient Hindu religious practices in viewing 
temple gods, can be best understood as a means of satisfying traditional understandings of kingship in both the Timurid dynastic and South Asian imperial ruling traditions.

The jharoka was a public viewing of the king; although access to the ruler in fact varied wildly in different settings and periods, a regnal appearance at the jharoka at the very least implied the possibility of imperial intervention. Theoretically, a subject could approach the window and demand the attention of the ruler. The first Mughal king to be described as holding a jharoka, as a formal court ritual in the local imperial tradition, was Akbar, who adopted a system of regular staged viewings at the window of the imperial palace. Even his enormous imperial tent, the du ashiyana manzil, was designed with a jharoka, a balcony and viewing window. ${ }^{740}$

An increasingly theatrical and performative jharoka emerged during the reign of Jahangir, whose interest in overt and public displays of Perso- Islamic imperial justice could be satisfied by daily appearances at the viewing balcony. Much as Babur had insisted on interaction with the imperial retinue, Jahangir's memoirs describe the jharoka as a duty of kingship, sometimes painful but always necessary. Powerfully affirming the access he offered to the general public, Jahangir describes offering the public audience, "as demanded by justice," while on a journey to Ahmadabad. Complaining of pain, illness, and the severity of the heat, the emperor yet dispensed imperial law "by the side of the river, where there is no kind of impediment like gates, walls, watchmen and guards. ${ }^{741}$

\footnotetext{
${ }^{740}$ Abu'l Fazl describes Akbar's massive two- story imperial tent/mobile royal dwelling as containing a jharoka, as a small upper-story window and balcony, from which the ruler could be viewed but also observe performances, "inspect the rations for the elephants and camels," watch animal fights, etc.. See AA, I, p. 55.

${ }^{741}$ Jahangirnama, p. 242. Thackston, tr., p. 264.
} 
His son and successor, Shah Jahan, was noted for the increasingly rigid and formal setting of his court, yet daily, just after sunrise, the emperor would sit at the jharoka-i dashan, in order that "the assembled masses in the plain beneath the window perform their obeisance and all their temporal and spiritual desires are satisfied." ${ }^{742}$ While Shah Jahan was theretically there to impose imperial justice, due to the emperor's "great solicitude," mused one of the court historians, Mughal imperial justice was already so complete and universal that few supplicants could be found who required the personal intervention of the king! ${ }^{743}$ In its increasingly performative and unsubstantial manifestations, the jharoka yet satisfied Mughal traditions of accessibility by offering their subjects a daily public viewing of the king, and even seeming to suggest the possibility of imperial intercession and justice, although, in reality, by the reign of Shah Jahan, few plaintiffs were brought before the king. ${ }^{744}$

Another example of Mughal use of traditions of rule that had a local, South Asian, resonance, can be found in the remarkable mobility of the kings. Through generations of Mughal rule in India, the political relevance of Mughal imperial cities remained very limited; it was physical mobility which lay at the center of Mughal imperial court life.

The Mughal kings came to view their regular movement as a strategic necessity. Aurangzeb, the sixth Mughal emperor, who died in 1707, left a will containing an advisory for his descendants. "As far as possible," he wrote, "the ruler of a kingdom should not spare himself from moving about; he should avoid staying in one place, which

\footnotetext{
${ }^{742}$ Ibid.

${ }^{743}$ Rai Bhara Mal, Lubbut Tawarikh-i Hind, E\&D, VII, p. 172.

${ }^{744}$ Ibid.
} 
outwardly gives him repose but in effect brings on a thousand calamities and troubles."745 "It is bad for both emperors and water to remain at the same place. The water grows putrid and the king's power slips out of his control. In touring lie the honour, ease and splendor of kings." 746

Apart from military and strategic necessity, the mobility of the Timurid- Mughal court was reinforced by the dynasty’s cultural affinity for a life lived out-of-doors. In contrast to his predecessors - conquest-driven, leaders of armies, warriors bent on domination and strategic displays of power-- Jahangir indulged in simple, aimless wandering, comfortably combining his own minimalist interpretation of imperial duties with life in a garden setting and the pursuit of pleasure. Weaving through magnificent countryside, pausing regularly for pleasure trips to famous sights, visits to local mystics, the personal distribution of alms, dispensation of imperial justice, and the daily hunt, Jahangir wrote, "The rest stops were all delightful places on the banks of ponds or irrigation canals and magnificent rivers edged by trees, greenery, and fields of blooming poppies, and not a day passed, whether marching or halting, without hunting. We came the whole way by horseback or elephant, seeing the sights and hunting." As if in affirmation of the dynastic passion for landscapes, the emperor added, "The arduousness of a journey (mishqat-i safar) was never apparent. It was as if we were moving from garden to garden."747

\footnotetext{
${ }^{745}$ Hamid al-Din Bahadur, Ahkam-i Alamgir, trans. by Jadunath Sarkar as Anecdotes of Aurangzeb, Calcutta: M.C. Sarkar and Sons, 1925.

${ }^{746}$ Gommans, Mughal warfare, pp. 67-81, and p. 105. Sarkar, tr., Anecdotes of Aurangzeb, p. 53 (Aurangzeb's advice to his son c. 1695).

${ }^{747}$ Jahangirnama, p. 207. Thackston, p. 214.
} 
The constant mobility of his royal court offered Jahangir the opportunity to satisfy his passion for the hunt, which he did almost daily. Totaling up the game killed since the age of twelve, Jahangir listed 28, 532 animals, including eighty-six lions, over 3,300 crows and ten crocodiles. ${ }^{748}$ Yet even this seemingly excessive hunting found justification in both Hindu and Timurid political traditions, for which the hunt was presented as a royal duty, an act of arbitration between his subjects and forces of nature which only the king was competent to control, and the first line of defense against the encroachment of a threatening nature. In the ancient Indian tradition, the "rulers had to interact with the wilderness, placate, contain and appropriate its raw power, ${ }^{, 749}$ whereby the king gained religious merit and the hunting ground became a ceremonial seat of royalty. Anxious to portray his constant hunting trips as a "disinterested service to his subjects," Jahangir regularly extolled his own role as imperial exterminator, describing explicit invitations from his subjects to have the emperor rid them of a tiger or lion which threatened their village.

In reality, however, Jahangir's personal itinerancy seems rarely to reflect more than his simple desire to live a life of feckless constant movement spent in the (classically Timurid) princely pleasures of hunting, garden parties and alcoholic or drug-induced pleasure, yet it seems that the mobility of the Jahangiri court found a degree of at least grudging acceptance within the royal retinue and among the imperial nobility. Much of Jahangir's nobility was, after all, descended from Persian or Turco- Mongol seminomadic warriors and empire builders, for whom the peripatetic court, even mobilized, as

\footnotetext{
${ }^{748}$ Ibid., p. 210.

${ }^{749}$ Allsen, Royal Hunt, p. 181.
} 
was Jahangir's, for the carefully justified pursuit of an endless round of hunts and drinking parties, was a well established and respected tradition.

But there also existed an ancient and respected South Asian precedent for his peripatetic court. A king's ritual courtly progress across his territories, the digvijaya, or "conquest of the quarters," was an act of powerful universal implications, affirming the legitimacy of imperial rule and the king as a chakravartin, a wheel turning ruler, who through conquest and alliance obliged the minor rulers of each circle to acquiesce in his self- centered world order. ${ }^{750}$ This geometric cosmology of empire, in fact, actually required a Hindu ruler to perform the "almost continual perambulation" of his domain, and the digvijaya ritual of kingship was carefully performed at Hindu courts across the subcontinent into the eighteenth century. For example, as late as 1674, the Marathan leader Shivaji, who had become the arch- nemesis of Aurangzeb and the Mughal armies of the Deccan, performed a formal ritualized digvijaya at the time of his assumption of rule, in part because, in the absence of a ksatriya (warrior) lineage, Shivaji seems to have recognized that publicly accepted rituals of consecration were required in order to substantiate his legitimacy. ${ }^{751}$

In the case of the emperor Jahangir, therefore, we have a confluence of imperial traditions which could appeal across the widely diverse Mughal imperial court-- which included Rajput nobles, Persian intellectuals, Turkish and Uzbek military men and local caste leaders-- in addition to having some legitimizing resonance within the Hindu subject population. Jahangir's own awareness of Hindu traditions of kingship goes

\footnotetext{
${ }^{750}$ Keay, India, p. 171-2. This recommendation for rulers was contained in a fourth- century B.C. Mauryan governing manual, the Arthashastra.

${ }^{751}$ Ibid., p. 354.
} 
entirely without comment in his writings, but it is worth noting that his mother was a princess of Rajasthan, where the royal ritual of the digvijaya had indeed been traditionally performed for centuries. ${ }^{752}$ It was not only the Turco- Mongol royal court tradition of mobility that made generous allowance for a king with a passion for hunting, a heartfelt appreciation for beautiful landscapes, a lifelong addiction to drugs and alcohol, and a dramatic lack of real imperial ambition--- all of which Jahangir comfortably indulged - but he, and generations of Mughal kings, also received the generous sanction of indigenous Hindu traditions of kingship.

While the Mughals could never be appropriately described as "indisputably Indian... emerging from the Indian historical experience,"753 just as their ancestors had developed a workable fusion of Perso- Islamic and Turco- Mongol cultures in Central Asia, Mughal dynastic survival was to some extent the product of their ability to meld the Timurid cultural personality with the reality of imperial rule in India. So successfully did the developing construct of an Indian Timurid- Mughal identity justify and legitimize their rulership that substantive threats to their rule came almost exclusively from within the dynasty.

Jahangir: Timurid Prince, King of India

A recent study of Babur's memoirs describes his writings as an effort to demonstrate his legitimate right to rule due to his nature as "the perfect man, or perfect ruler." In late Timurid Transoxiana the perfect ruler was a "Persianized, Islamicized

\footnotetext{
${ }^{752}$ It was the twelfth-century Rajput king Prithviraj, having succeeded in uniting some of the Rajput princes and cordoning off the Muslim Panjab, was performing a ritual digvijaya when he was attacked by the eventually victorious Muhammad al- Ghur, who established what came to be known as the Delhi sultanate.
} 
Turco- Mongol aristocrat... an adib, a cultured, civilized man and therefore, partly for that reason, qualified to rule." ${ }^{754}$ It is clear that, through the device of royal memoirs, first Babur, then his great-grandson, the emperor Jahangir, was describing his own right to rule, in each case carefully following the model of Timurid ancestors. Remarkably, Jahangir's presentation of himself as a legitimate ruler shows little modification in the generations since Babur's reluctant conquest of northern India, reflecting a notable degree of continuity in Mughal retention of the values of the late Timurid rulers of Transoxiana. There are few clues in his personal writings that Jahangir identified himself as an Indian emperor rather than Timurid.

Much as their adaptations and assimilations worked to establish the Mughals as legitimate kings of India, the remarkable success of the Mughals continued to spring in large part from loyal allegiance to their identity as Timurids, so charismatic had that dynastic legacy come to be. While his imperial performance included features which must have resonated in the Hindu Indian context, in the composition of his memoirs, Jahangir defined and presented his own identity and the character of his empire entirely in direct response to the advice and example of his imperial predecessors in Central Asia. His presentation of kingship and empire can be viewed as a reflection of the looming Timurid legacy of his dynasty. Jahangir's great-grandfather Babur, and the flood of Timurid refugees who had accompanied him into India, had left the Mughals with an obsession for his lineage which seems to have overwhelmed the possibility of another,

\footnotetext{
${ }^{753}$ Richards, Mughal History, p. 3.

${ }^{754}$ Dale, Garden, p. 466.
} 
alternative identity formation-- even when the Timurid cultural package was no longer sufficient to define the entirety of their dynastic identity in India.

One can imagine Jahangir's reaction, were he alive today, to the vagaries of history which have positioned him and his dynasty as an Indian monarchy, "born entirely of the Indian experience," rather than the Persianized, Islamicized, Turco- Mongol Timurids of his, and their own, imagining. The field of Timurid-Mughal studies requires a better understanding of their historical, cultural and political context, not simply to affirm the Mughal inheritance of a Central Asian fusion of religious and political traditions but to explore the migration and retention of a charismatic genealogical identity which had been carried to the subcontinent by this dynasty in the interests of imperial legitimacy, where it was passionately, even compulsively, retained as an affirmation of the dynasty's central position in the larger early modern Islamic community. 
APPENDIX

MAP AND GENEALOGICAL CHARTS 
THE TIMURIDS OF MAWARANNAHR

$$
\text { Timur (Guregen) Barlas }
$$$$
\text { (1336- 1405) }
$$

Jahangir Umar Shaykh Miranshah Shahrukh

$(1354-94) \quad(1367-1408) \quad(1377-1447) \quad(1356-76)$

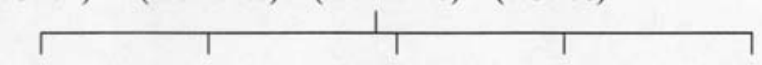

Abu Bakr Umar Sultan-Muhammad Khalil Sultan Soyurghatmish $\begin{array}{llll}(1382-1409)(1383-1407) & \text { (?) } & (1384-1411) & \text { (b. 1399) }\end{array}$

Sultan Abu Said Mirza (1424-69)

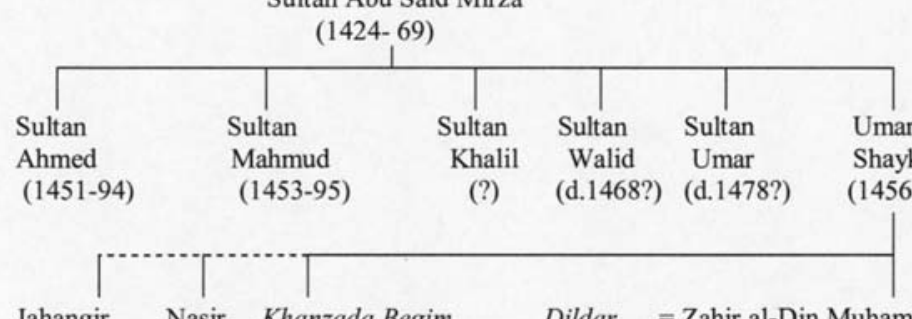

Jahangir Nasir Khanzada Begim Dildar = Zahir al-Din Muhammad BABUR (1483-1530) $=$ Maham Begim (d. 1507?) (d. 1515) (1477-1545) (mother of Gulbadan, Gulrang, Hindal)

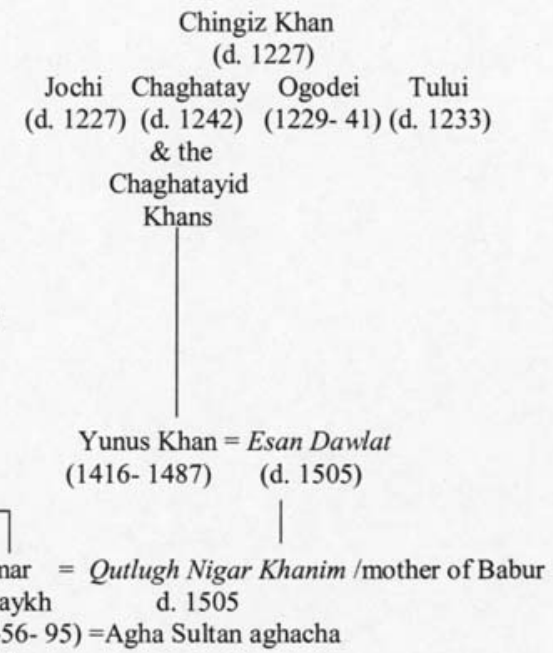

hingiz Khan

Jochi Chaghatay Ogodei Tului

$$
\text { \& the }
$$

Chaghatayid

Khans

Yunus Khan $=$ Esan Dawla

(1416-1487) (d. 1505)

6- 95) =Agha Sultan aghacha 


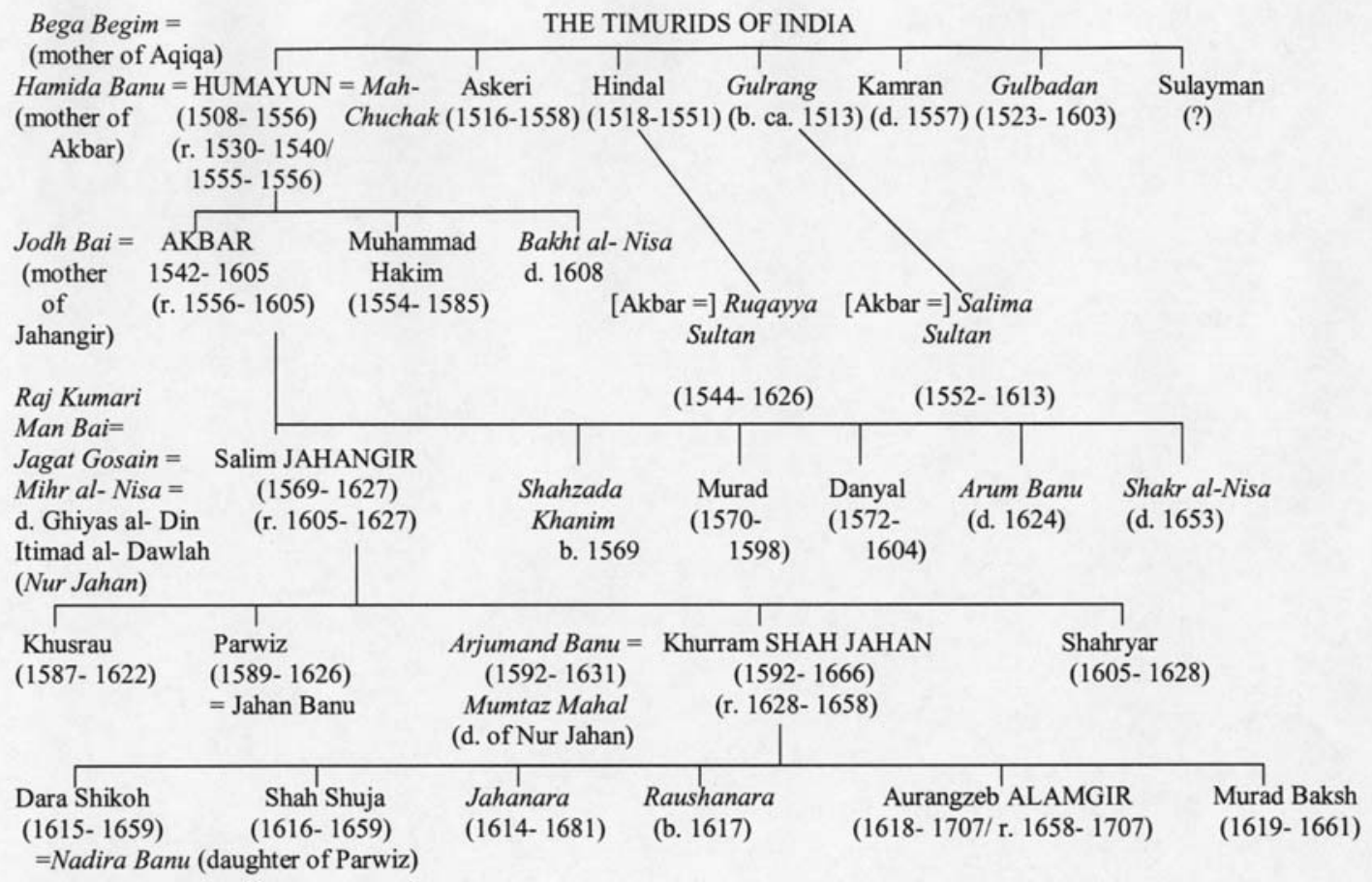




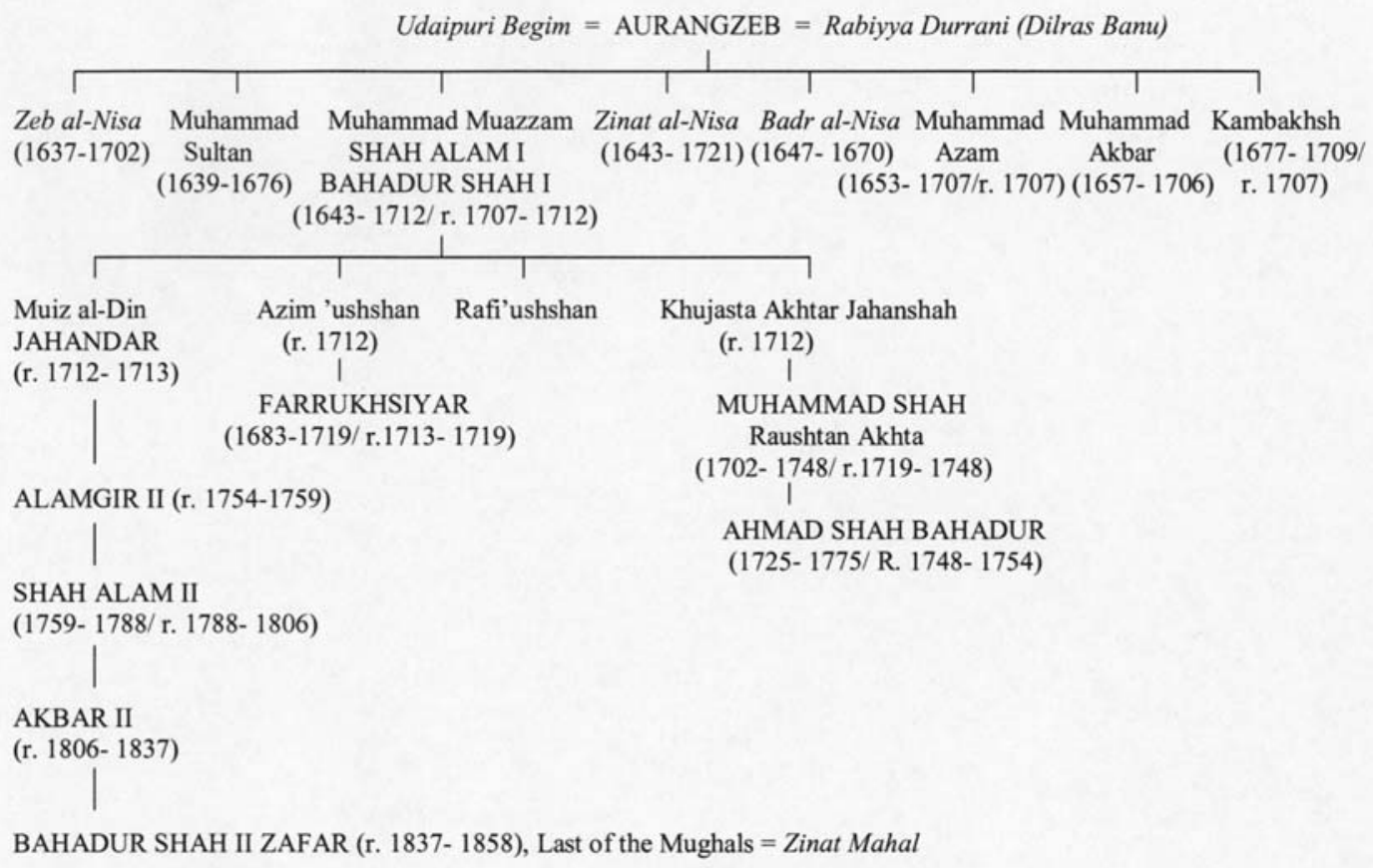

SHAH ALAM II

(1759- 1788/r. 1788- 1806)

AKBAR II

(r. 1806-1837)

BAHADUR SHAH II ZAFAR (r. 1837- 1858), Last of the Mughals = Zinat Mahal 


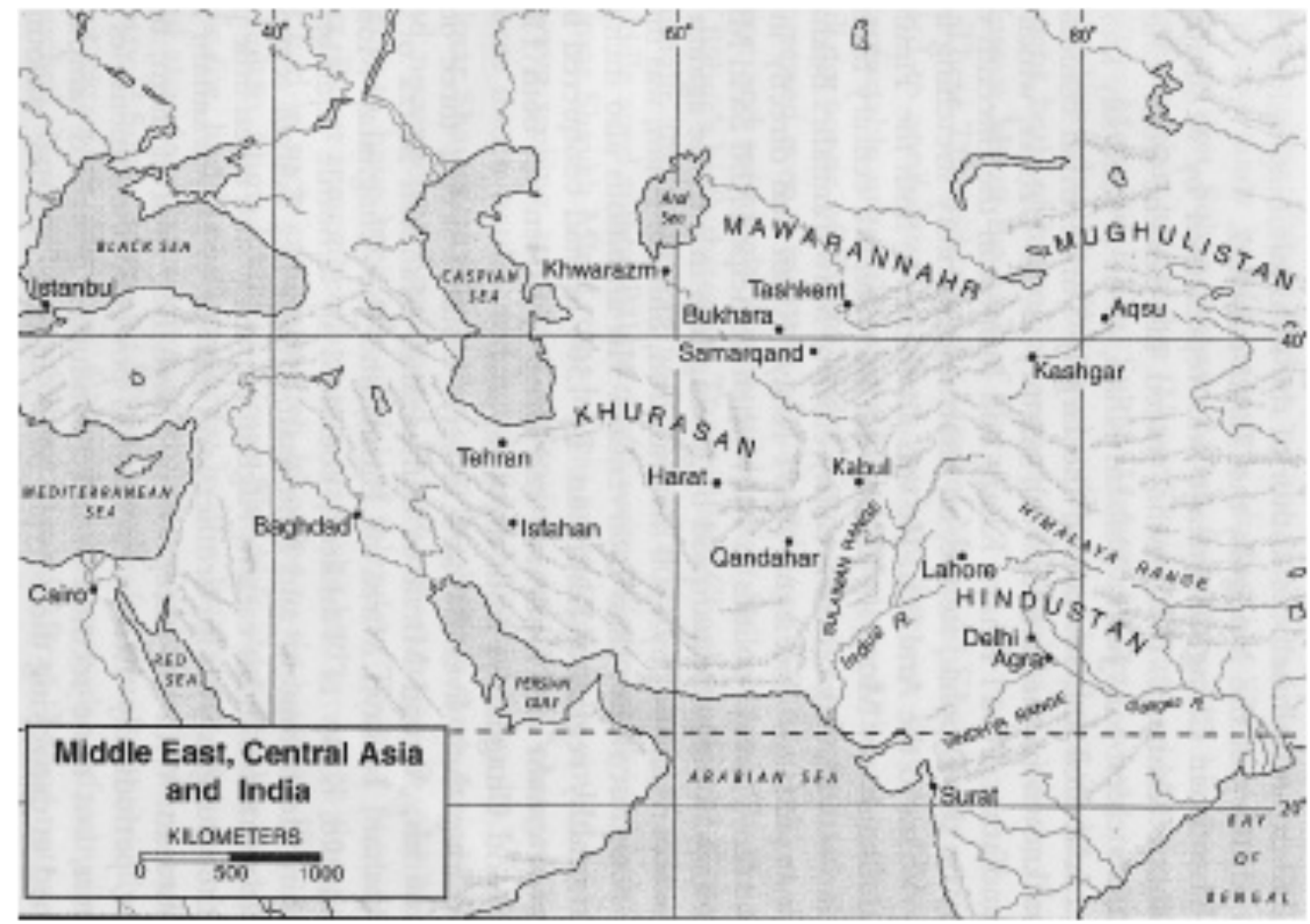




\section{BIBLIOGRAPHY}

Primary Sources:

Ahmad, Bakhshi Khwajah Nizam al- Din. Tabaqat-i Akbari (a history of India from the early musalman invasions to the $38^{\text {th }}$ year of the reign of Akbar). Brajendranath De, tr., Baini Prashad, ed.. Delhi: Low Price Publications 1939, reprint 1990.

(Nizamu-d Din Ahmad, Bakshi). "Tabiqat-i Akbari." In History of India. Elliot and Dowson. New York: AMS Press, Inc. (1966), V, 177- 476.

Ahmad, Mawlana (Maulana), et al.. "Tarikh-i Alfi." In History of India. Elliot and Dowson. New York: AMS Press, Inc. (1966), V, 150- 76.

Alamgir (Aurangzeb). Dastur al'Amal-i Agahi. (Collected letters). India Office MS Add 18881.

. Ruka'at-i-Alamgiri. (Collected letters). Jamshid H. Bilmoria, ed.. Delhi: Idarah-i Adabiyat-i Delli, 1972.

Allami, Abu'l Fazl. 'Ain ('Ayn) -i Akbari. Vol. 1, H. Blochmann, tr. $2^{\text {nd }}$ ed. Lieut. Colonel D.C. Phillott, ed. New Delhi: Munshiran Manoharlal Pub. Pvt. Ltd., $3^{\text {rd }}$ ed., 1977. Vols. 2 and 3, Colonel H.S. Jarrett, tr. and ed. $2^{\text {nd }}$ ed., Sir Jadunath Sarkar, ed., $3^{\text {rd }}$ ed. 1977.

. Akbarnama, H. Beveridge, tr.. 3 vols., Delhi: Manmohan Satish Kumar, Rare Books, $1^{\text {st }}$ Indian edition, 1972.

Anonymous (I). "Synoptic Account of the House of Timur." In Century of Princes. Thackston, tr. and ed.. Cambridge, Mass.: The Aga Khan Program for Islamic Architecture (1989), 237- 246.

Anonymous (II). "Intikhab-i Jahangir Shahi." In History of India. Elliot and Dowson, ed. New York: AMS Press, Inc. (1966), VI, 446- 52.

Asad Beg (Kaswini). "Wikaya.” In History of India. Elliot \& Dowson, ed. New York: AMS Press, Inc. (1966), VI, pp. 150- 174. 
Babur, Zahir al-Din Muhammad. Vaqi'at-i Baburi. India Office MS OR 3714. [Original translation from Chaghatay into Persian by 'Abdul Rahim Khan for Emperor Akbar. Includes 68 entire pages of miniatures and 48 smaller drawings in body of text. Currently on special exhibit, British Library, London.]

. Baburnama (Vekayi), Critical Edition Based on Four Chaghatay Texts. Eiji

Mano, ed.. Japanese and Chaghatay, 4 vols., Kyoto: Syokado, 1995.

. Baburnama. W. Thackston, ed. and tr.. Chaghatay, Persian and English, 3 vols., Cambridge, Mass.: Harvard University Department of Near Eastern Languages and Civilizations, 1993.

. The Baburnama in English. Annette Susannah Beveridge, tr.. London: Luzac and Company, Ltd., 1969.

. Vekayi Babur'un Hattiratı. Reşit Rahmeti Arat, ed. and tr., Turkish text, 3 vols., Ankara: Türk Tarih Kurumu Basımevi, 1946.

al-Badauni (Badaoni), Abdul Qadir Ibn Muluk Shah. Muntakhabut al-Tawarikh. W.H. Lowe, tr. and ed. 3 vols., Patna, India: Academica Asiatica, 1973.

Bahadur, Hamid al-Din Khan. Ahkam-i Alamgiri. India Office MS BM 14807.a.10.

. Anecdotes of Aurangzeb. Jadunath Sarkar, tr.. Calcutta: M.C. Sarkar and Sons, 1927.

Bayat, Bayazid. Tazkirah-i Humayun ve Akbar. M. Hidayet Hosayn, ed. Calcutta: Bibliotheca Indica, 1941.

Bayqara, Mirza Sultan Husayn. "Apologia.” In A Century of Princes, Wheeler Thackston, tr. and ed. Cambridge, Mass.: The Aga Khan Program (1989), 37378.

Bernier, Francois. Travels in the Mogul Empire, AD 1656-1668. Archibald Constable, tr. London: Cambridge University Press, 1934. New Delhi: Munshiram Manoharlal Publishers Pvt. Ltd., Oriental Reprint, 1983. Delhi: Low Price Publications, 2005.

Clavijo, Ruy Gonzales de. Embassy to Tamerlane, 1403- 1406. Guy Le Strange, tr. New York and London: Harper Brothers, 1928.

Coverte, Robert. A True and Almost Incredible Report of an Englishman. London, 1612, reprint Amsterdam and New York: Da Capo Press, 1971. 
Dara Shikuh (Shikoh). Majma' ul- Bahrain (The Mingling of Two Oceans). M. Mahfuzul-Haq, tr. Calcutta: The Asiatic Society, 1929, reprint 1982.

. Sirr-i Akbar (Upanishads). Tara Chand and J. Na'ini, eds. Tehran, 1957- 60.

East India Company. Letters received by the East India Company from Its Servants in the East. 2 vols. London, 1896, reprint Amsterdam, N. Israel, 1968.

Elliot, Sir H.M. and John Dowson. The History of India as told by its own historians: the posthumous papers of Sir H.M. Elliot. John Dowson, ed. 8 vols. London: Trubner and Co. 1872, New York: AMS Press, Inc., 1966.

Ferishta, Muhammad Kasim. Gulshan-i Ibrahimi (History of the Rise of Mahomedan Power in India). John Briggs, tr. Calcutta: Editions Indian 1829, reprints 1908, 1966.

Foster, Sir William. The English Factories in India, 1618- 1621 (a calendar of documents in the India Office and British Museum) Oxford: Clarendon Press, 1906.

Gulbadan Begim. Humayunnama (The History of Humayun). Persian and English text, Annette S. Beveridge, ed. and trans., Delhi: Idarah-i Adabiyat-i Delli, 1972.

Hadi, Muhammad. "Preface to the Jahangirnama." In The Jahangirnama, Memoirs of Jahangir, Emperor of India. Wheeler M.Thackston, tr. New York: Oxford University Press, in association with the Freer Gallery of Art and the Arthur Sackler Gallery, Smithsonian Institution, Washington, D.C., 1999.

Hafiz (Hafez). Drunk on the Wine of the Beloved:100 Poems of Hafiz. Thomas Rain Crowe, trans. and ed. Boston and London: Shambhala, 2001.

Ibn Arabshah, Ahmed ibn Muhammad. Tamerlane, or Timur the Great Amir. J.H. Sanders, tr. Lahore: Progressive Books, 1936, reprint 1976.

Dughlat, Mirza Haydar. Tarikh-i Rashidi: A History of the Khans of Moghulistan. W.M. Thackston, ed. and trans. Persian and English 2 vols. Cambridge, Massachusetts: Harvard University Department of Near Eastern Languages and Civilizations, 1996.

Faizi (Fayzi), Shaykh. "Waki'at." In History of India. Elliot and Dowson, eds. New York: AMS Press, Inc. (1966), VI, 147- 74.

Husaini, Khwaja Kamgar. Maathir (Ma'asir)-i Jahangiri. India Office MS OR 171. 
. Ma'asir-i Jahangiri (A Contemporary Account of Jahangir). Azra Alavi, ed. (Persian text with brief English intro.) New York: Asia Publishing House, Inc., 1978.

Ibn Arabi. Tarjuman al-Ashwaq. R.A. Nicholson, tr. London, 1911.

Inayat Khan. Shah Jahan Nama. A.R. Fuller, tr. W.E Begley and Z.A. Desai, eds. Delhi, NY, and London: Oxford University Press, 1990. Also in History of India, Elliot \& Dowson, eds. VII, 73- 120.

Inayatullah. "Takmila-i Akbarnama." History of India, Elliot \& Dowson, eds. New York: AMS Press, Inc. (1966), VI 103- 115.

Jahangir, Nur al-Din Muhammad. Jahangirnama. India office MS OR 1644. . Jahangirnama (Tuzuk-i Jahangiri). Tehran: Buny adi Farhangi Iran, 1359 (1980). . The Jahangirnama, Memoirs of Jahangir, Emperor of India. Wheeler M. Thackston, tr. New York: Oxford University Press, in association with the Freer Gallery of Art and the Arthur Sackler Gallery, Smithsonian Institution, Washington, D.C., 1999.

. "Tatimma-i Waqi'at-i Jahangiri.” In History of India. Elliot \& Dowson, eds. New York: AMS Press, Inc. (1966), VI, 392- 99.

. Jahangir, memoirs of the Emperor Jahangueir written by himself. Major David Price, tr. (false) London: Oriental Translation Committee 1829.

Jauhar Aftabchi. Tazkirat-e-Waqi'at (Tadkhirat-i Waqi'at, Tarikh-e-Humayun, Humayun Shah, Jawahir-e-shahi). India Office MS Add 16711

. Tezkereh al Vakiat. Major C. Stewart, tr. India Office MS Add 26608. (translation heavily revised by W. Erskine, India Office MS Add 26620).

. Tezkereh al Vakiat, Memoirs of the Emperor Humayun. Major Charles Stewart, tr. New Delhi: Kumar Brothers, 1970.

al- Juwayni (Juvaini), Ala-ad-Din 'Ata Malik. Tarikh-i Juhan Gusha. M.M. Qazvini, ed. 3 vols, Leiden and London, 1912, 1916, 1937.

. The History of the World Conqueror. John Andrew Boyle, tr.. 2 vols. Cambridge, Massachusetts: Cambridge University Press, 1958.

Kambu (Kambo), Muhammad Salih. “Amal-i Salih.” In History of India. Elliot and Dowson, eds. New York: AMS Press, Inc. (1966), VII, 123- 132. 
Kamgar Khan. "Ma'asir-i Jahangiri.” In History of India. Elliot \& Dowson, eds. New York: AMS Press, Inc. (1966), VI, 439- 445.

Kazwini, Muhammad Amin. "Padshahnama." In History of India. Elliot \& Dowson, eds. New York: AMS Press, Inc. (1966), VII, 1- 3.

Kazim, Muhammad. “Alamgirnama.” In History of India. Elliot and Dowson, eds. New York: AMS Press, Inc. (1966), VII, 174- 180.

Khafi Khan, Muhammad Hashim. History of Alamgir. S. Moinul Haq, tr. Calcutta: Bibliotheca Indica, 1860- 74. Repr. Karachi: Pakistan Historical Society, 1975. . "Muntakhabu-1 Lubab.” In History of India. Elliot \& Dowson, eds. New York: AMS Press, Inc. (1966), VII, 207- 533.

Khwandamir, Ghiyas al-Din Muhammad. "Habib al- Siyar." In Century of Princes. Wheeler Thackston, tr. and ed. Cambridge, Massachusetts: The Aga Khan Program for Islamic Architecture (1989), 101- 235.

- Qanun-i Humayuni (Humayunnama of Khwandamir). M. Hidayat Hosain, ed. Calcutta: Royal Asiatic Society of Bengal, 1940.

Lahori, Abdul- Hamid and Muhammad Waris. Padshahnama. Kabir al- Din Ahmad and Abal Raman, eds. Calcutta: Royal Asiatic Society of Bengal 1867. A. R. Fuller, tr. and ed., 1851, reprint. 1990.

. "Badshahnama.” In History of India. Elliot \& Dowson, eds. New York: AMS Press, Inc. (1966), VII, 3- 72.

al-Marghinani, 'Ali ibn Abi Bakr. The Hedaya or Guide: A Commentary on the Mussulman Laws. Charles Hamilton, tr. $2^{\text {nd }}$ ed.1870, reprint Lahore: Premier Book House, 1963.

Mir Khan (Subadar of Kabul), or Sayyid Mir, Zafarnama-i Padishah Alamgiri. India Office MS Add 26234.

Manucci, Niccolao. Memoirs of the Mogul Court. Michael Edwardes, tr. London: Folio Society, 1957.

Father Montserrate. The Commentary of Father Monserrate. J.S. Hoyland, tr. and S.N. Bannerjee, ed. Cuttack, 1922.

Moosvi, Shireen. Episodes in the Life of Akbar; Contemporary Records and Reminiscences. New Delhi: National Book Trust, 1994. 
Mirza Muhammad. T’arikh-i Jahan Gusha. London, 1912. J.A. Boyle, tr. Manchester, 1958.

Musta'idd Khan, Muhammad Saki. "Ma'asir-i Alamgiri." In History of India. Elliot and Dowson, eds. New York: AMS Press, Inc. (1966), VII, 181- 197.

Mu'tamid Khan, Muhammad Sharif. Iqbalnamah-i Jahangiri. India Office MS Add. 26218 [1806 trans. by J. Macmurdo India Office MS EUR. F 26 and condensed tr. by Erskine, MS Add 26612].

. "Iqbalnama-i Jahangiri.” In History of India. Elliot \& Dowson, eds. New York: AMS Press, Inc. (1966), VI, 400- 438.

Nawa'i, Mir Ali Sher. "Preface to his First Turkish Divan: Gharayib al- Sighar." In Century of Princes, Wheeler Thackston, tr.and ed. Cambridge, Masschusetts.: The Aga Khan Program for Islamic Architecture (1989), 363- 372.

Nathan, Mirza. Baharistan-i Ghaybi. M. I. Borah, tr. 2 vols. Gauhati: Government of Assam, 1936.

Nizam al-Mulk. Siyasatnama (The Book of Government). Hubert Darke, tr. London, Boston: Routledge \& Kegan Paul, 1978.

Pelsaert, Francis. A Dutch Chronicle of Mughal India. Brij Narain and Sri Ram Sharma, tr. and ed. Lahore: Sang-e-Meel Publications, 1978.

Qabil Khan, Musavvadat Munshi al Mamalik Shaykh Abu al- Fath Sadiq Mutlabi Anbalvi. Adab-i Alamgiri. India Office MS OR 177.

. Adab-i Alamgiri. Abdul Ghafur Chaudhari, ed. Lahore: Idarah-i Tahqiqat-i Pakistan and People's Publishing House, 1941.

Rai Bhara Mal. "Lubbu-t Tawarikh-i Hind.” In History of India. Elliot \& Dowson, eds. New York: AMS Press, Inc. (1966), VII, 168- 173.

Ramzi, Sayyid Tabib Hasan. Ruqa'at-i Alamgiri. India Office MS Per D, 1861. . Ruka'at-i Alamgir. Diyoband: Mas'ud Publishing Haus, 1968.

Rashid al- Din. The Successors of Genghis Khan. John Andrew Boyle, tr. New York: Columbia University Press, 1971.

Razi, ‘Aqil Khan. Waqiyat-i Alamgiri. India Office MS Per. D. 84. 
. Waqiyat-i Alamgiri. Khan Bahadur Mawlvi Haji Zafar Hasan, ed. Delhi:

Mercantile Printing Press, 1946.

Roe, Sir Thomas. Embassy to the Court of the Great Mogul, 1615- 1619. W. Foster, ed. London: Hakluyt Society, 1899.

Sadasukh (Dehlawi), Munshi. "Muntakhabu-t Tawarikh." In History of India. Elliot and Dowson, eds. New York: AMS Press, Inc. (1966), VIII, 403- 411.

Sa'di Shirazi. A Thousand Years of Persian Rubaiyat. Reza Saberi, tr. Bethesda, Maryland: IBEX Publishers, 2000.

Sadik Khan, Muhammad. "Shah Jahan Nama.” In History of India. Elliot and Dowson, eds. New York: AMS Press, Inc. (1966), VII, 133-4.

Samarqandi, Mir Dawlatshah. "Tadhkirat al-shu ara.” In Century of Princes. Wheeler Thackston, tr. and ed., Cambridge, Massachusetts.: The Aga Khan Program for Islamic Architecture (1989), 11- 62.

Samarqandi, Mutribi al- Asamm. Khatirat-i-Mutribi. Abdul Ghani Mirzoyef, ed. Karachi: University of Karachi, 1977.

. ["Murtib" al- Assam]. Conversations With Emperor Jahangir. Richard C. Foltz, tr. Mazda Publishers, 1998.

Saqi Must'ad Khan. Ma'asir-i Alamgiri. India Office MS B.I. 269.

. History of the Emperor Aurangzeb-Alamgir. Jadunath Sarkar, tr. Calcutta: Royal Asiatic Society of Bengal, 1947, and New Delhi: Munshiram Manoharlal Publishers Pvt. Lmt., 1986.

Shah Nawaz Khan, Nawab Samsam ud- Daula, and Abdul Hayy. Maathir (Maasir)-ul- Umara: biographies of the Muhammadan and Hindu Officers of the Timurid Sovereigns of India from 1500 to about 1780 A.D.. 2 vols., H.

Beveridge, trans. Baini Prashad, ed. Calcutta: The Asiatic Society, 1952. Delhi: Low Price Publications, 1999.

Sharif Hanafi, Muhammad. "Majalisu-s-Salatin.” In History of India. Elliot \& Dowson, eds. New York: AMS Press, Inc. (1966), VII, 134- 140.

Thackston, Wheeler M., trans. and ed.. A Century of Princes: Sources on Timurid History and Art, Cambridge, Massachusetts: The Aga Khan Program for Islamic Architecture, published in conjunction with the exhibition "Timur and the Princely Vision," 1989. 
Tirmizi, S.A.I.. Edicts from the Mughal Harem. Delhi: Idarah-i Adabiyat-i Delli, 1979.

Tusi, Nasir al- Din. Akhlaq-i Nasiri. Tehran: Shirket-i Salami-ye Intishirat-e Khorazm, $5^{\text {th }}$ ed., 1373 (1994). . Akhlaqi Nasiri (The Nasirean Ethics). G.M. Wickens, tr. London: George Allen and Unwin, Ltd., 1964.

Tavernier, Jean- Baptiste, Travels in India, V. Ball, tr. [from French ed. of 1676] $2^{\text {nd }}$ ed. William Crooke, ed. London: Oxford University Press 1925, reprint Delhi: Low Price Publications, 2000.

Yazdi, Sharafuddin Ali. "Zafarnama." In Century of Princes. WheelerThackston, tr. and ed. Cambridge, Massachusetts.: The Aga Khan Program for Islamic Architecture (1989), 63- 100.

Silsilahnamas (genealogical scrolls):

1. Ottoman genealogy from Adam to Abdul Mecid, India Office MS OR 7309.

2. Biographical notices and portraits of Ottoman sultans to Abdul Mecid, India Office MS OR 9505.

3. Mir'at al-ashbah-i salatin-i asman jah, Timurid chronological tables, India Office, MS OR 182.

4. Mu'izz al- Ansab, Timurids through Badi' al- Zaman [illustrated], India Office, MS OR 467.

Secondary Sources:

Abdul Aziz, Sh.. The Imperial Library of the Mughals. Delhi: Idarah-i Adabiyat-i Dell,i 1974.

Alam, Muzaffar. "Akhlaqi Norms and Mughal Governance.” The Making of IndoPersian Culture. Muzaffar Alam, Francoise 'Nalini' Delvoye and Marc Gaborieau, eds. New Delhi: Manohar (2000), 67- 95.

, Francoise 'Nalini' Delvoye, and Marc Gaborieau, eds. The Making of IndoPersian Culture. New Delhi: Manohar, 2000.

and Sanjay Subrahmanyam. The Mughal State, 1526- 1750. New Delhi: Oxford University Press, 1998.

. "The Pursuit of Persian: Language in Mughal Politics." Modern Asian Studies 32, 2 (1998), 31-49. 
. "State Building Under the Mughals." L'Heritage Timouride, Iran- Asie CentralInde, XVe-XVIIIe Siecles, Les Cahiers d'Asie Centrale. Maria Szuppe, ed. Tachkent- Aix-en-Provence (1997), 105- 128.

Algar, Hamid. "The Naqshbandis and Safavids: A Contribution to the Religious History of Iran and Her Neighbors." Safavid Iran and Her Neighbors. Michel Mazzaoui, ed. Salt Lake City, Utah: The University of Utah Press (2003), 7- 48.

. "The Naqshbandi Order: A Preliminary Survey of Its History and Significance." Studia Islamica 44/136 (1976), 123- 152.

. "Political Aspects of Naqshbandi History." Naqshbandis: Cheminements et situation actuelle d'un ordre mystique musulman. Actes de la Table Ronde de Sèvres. Marc Gaborieau, et al., eds. Editions Isis: Istanbul (1985, 1990), 123- 152.

Ali, M. Athar. "The Passing of Empire: The Mughal Case." Modern Asian Studies 9, 3 (1975), 385- 96.

Allen, Terry. Timurid Herat. Weisbaden: Ludwig Reichart, 1983.

Allsen, Thomas T. Commodity and Exchange in the Mongol Empire. Cambridge: Cambridge University Press, 1997. . Culture and Conquest in Mongol Eurasia. Cambridge: Cambridge University Press, 2001.

. The Royal Hunt in Eurasian History. Philadelphia, PA: University of Pennsylvania Press, 2006.

Anderson, Benedict. Imagined Communities: Reflections on the Origin and Spread of Nationalism. London: Verso Editions, 1983.

Andrews, Walter G., Najaat Black and Mehmet Kalpaki, eds. and trs. Ottoman Lyric Poetry. Austin, Texas: University of Texas Press, 1997.

Arberry, A.J.. Fifty Poems of Hafiz. Richmond, Surrey: Curzon Press Ltd., 1947, corrected 1953, reprints 1962, 1970.

Asher, Catherine B.. “Architecture.” The Magnificent Mughals. Zeenut Ziad, ed. Oxford, UK: Oxford University Press (2002), 183- 228.

Avery, Peter "Nadir Shah and the Afsharid Legacy." The Cambridge History of Iran. VII Peter Avery, Gavin Hambly and Charles Melville, eds. Cambridge: Cambridge University Press (1991), 3- 62. 
Avery Peter, Gavin Hambly and Charles Melville, eds. The Cambridge History of Iran. VII [Nadir Shah to the Islamic Republic] Cambridge: Cambridge University Press, 1991.

Azra, Azyumardi The Origins of Islamic Reformism in Southeast Asia, Honolulu: University of Hawai'i Press, 2004.

Babayan, Kathryn. “The 'Aqa'id al-Nisa:' A Glimpse of Safavid Women in Local Isfahani Culture.” Women in the Medieval Islamic World. Gaven Hambly, ed. New York: St. Martin's Press (1998), 349- 382.

Balabanlilar, Lisa. "Lords of the Auspicious Conjunction: Turco- Mongol Imperial Identity on the Subcontinent." The Journal of World History 18, 1 (2007) 1- 39.

Barnett, Richard B.. "Embattled Begims: Women as Power Brokers in Early Modern India." Women in the Medieval Islamic World Gaven Hambly, ed. (1998), $521-36$.

Beach, Milo C.. "Jahangir's Jahangir- Nama.” Powers of Art. Barbara Stoler Miller, ed. Delhi: Oxford University Press (1992), 224- 234.

Blake, Stephen. "Contributors to the Urban Landscape: Women Builders in Safavid Isfahan and Mughal Shahjahanabad." Women in the Medieval Islamic World. Gavin R.G. Hambly, ed. New York: St. Martin's Press (1998), 407- 428.

. "The Patrimonial- Bureaucratic Empire of the Mughals." Journal of Asian Studies 39, 1 (1979), 77-94.

Bosworth, C. Edmund. The Ghaznavids: Their Empire in Afghanistan and Eastern Iran, 994- 1040. Edinburgh: Edinburgh University Press, 1963.

Boyle, John Andrew. The Successors of Genghis Khan. New York: Columbia University Press, 1971.

Brubaker, Rogers and Frederick Cooper. "Beyond 'Identity." Theory and Society 29, 1 (2000), 1- 47.

Buehler, Arthur F.. Sufi Heirs of the Prophet: The Indian Naqshbandiyya and the Rise of The Mediating Sufi Saint. Columbia: University of South Carolina Press, 1998.

Burke, Peter. The Fabrication of Louis XIV. New Haven and London: Yale University Press, 1992.

Chandra, Satish. Parties and Politics at the Mughal Court, 1707-1740. New Delhi: Oxford University Press, 2002-3. 
Dale, Stephen F. and Alam Payind. "The Ahrari Waqf in Kabul in the Year 1546 and the Mughal Naqshbandiyyah.” The Journal of Asian Studies 119, 2 (1999), 210- 33.

Dale, Stephen F.. The Garden of the Eight Paradises: Babur and the Culture of Empire in Central Asia, Afghanistan and India (1483- 1530). Leiden: Brill 2004.

. "The Legacy of the Timurids." Journal of the Royal Asiatic Society, Series 3, 8, 7 (1998), 43- 58.

. "The Poetry and Autobiography of the Baburnama." The Journal of Asian Studies, 55, 3 (1996), 635- 64.

. "Steppe Humanism and the Autobiographical Writings of Zahir al-Din Muhammad Babur, 1483- 1530.” International Journal of Middle Eastern Studies 22 (1990), 37-58.

Dalrymple, William. The Last Mughal, The Fall of a Dynasty: Delhi, 1857. New York: Alfred A. Knopf, 2006.

Damrel, David W.. “The 'Naqshbandi Reaction' Reconsidered.” Beyond Turk and Hindu: Rethinking Religious Identities in Islamicate South Asia. David Guilmartin and Bruce B. Lawrence, eds.. Gainsville, Florida: University Press of Florida (2000), 55- 73.

Darling, Linda T.. “'Do Justice, For That is Paradise!': Middle Eastern Advice for Indian Muslim Rulers." Comparative Studies of South Asia, Africa, and the Middle East XXII 1\&2 (2002), 3- 19.

DeWeese, Devin. "The Descendants of Sayyid Ata and the Rank of Naqib in Central Asia." Journal of the American Oriental Society 115, 4 (1995), 612- 34.

, ed. Studies on Central Asian History, In Honor of Yuri Bregel. Bloomington, Indiana: Indiana University, Research Institute for Inner Asian Studies, 2002.

Dickie, James. "The Mughal Garden: Gateway to Paradise," Muqarnas 3 (1985), 128137.

Digby, Simon. Sufis and Soldiers in Awrangzeb's Deccan. New Delhi: Oxford University Press, 2001.

Dye, Joseph M., III. “Imperial Mughal Painting.” The Magnificent Mughals. Zeenat Ziad, ed., Oxford University Press (2002), 143- 182. 
Eaton, Richard M., ed.. India's Islamic Traditions, 711- 1750. New Delhi: Oxford University Press, 2003.

. A Social History of the Deccan, 1300-1671, Eight Indian Lives.Cambridge: Cambridge University Press, 2005.

Faruqui, Munis. "The Forgotten Prince: Mirza Hakim and the Formation of the Mughal Empire in India." JESHO 48, 4 (2005), 487- 523.

. "Princes and Power in the Mughal Empire, 1569- 1657." unpublished PhD dissertation, Department of History, Duke University, 2002.

Fleischer, Cornell. Bureaucrat and Intellectual in the Ottoman Empire: The Historian Mustafa Ali (1541-1600). Princeton, NJ: Princeton University Press, 1986.

Fletcher, Joseph. "Turco- Mongolian Monarchic Traditions." Eucharistion (Harvard Ukrainian Studies) III-IV (1979-80), 136- 51.

Friedmann, Johanan. "Nizami, Naqshbandi Influence on Mughal Rulers and Politics." Islamic Culture XXXIX (1965), 40- 53.

. Shaykh Ahmad Sirhindi, An Outline of His Thought and a Study of His Image in the Eyes of Posterity. Montreal and London: McGill University Press, 1971.

Foltz, Richard C.. Mughal India and Central Asia. Karachi: Oxford University Press, 1998.

Gaborieau, Marc, Alexandre Popovic, Thierry Zarcone, eds. Naqshbandis: Cheminements et situation actuelle d'un ordre mystique musulman. Actes de la table Ronde de Sèvres Istanbul and Paris: Isis Press, 1985/1990.

Golden, Peter B.. An Introduction to the History of the Turkic Peoples. Weisbaden: Harrassowitz, 1992.

Golombek, Lisa and Maria Subtelny, eds. Timurid Art and Culture: Iran and Central Asia in the Fifteenth Century. Leiden, NY, Koln: E.J. Brill, 1992.

Gommens, Jos J.L. and Dirk H.A. Kolff, Warfare and Weaponry in South Asia, 10001800, A.D. Delhi: Oxford University Press, 2001.

Gross, JoAnn. "Khoja Ahrar: A Study of the Perceptions of Religious Power and Prestige in the Late Timurid Period." unpublished PhD dissertation, New York University, 1983. 
. "Multiple Roles and Perceptions of a Sufi Shaikh: Symbolic Statements of Political Power and Religious Authority." Naqshbandis. Marc Gaborieau, et al, eds. (1990), 109- 121.

. "Naqshbandi Appeals to the Herat Court: A Preliminary Study of Trade and Property Issues." Studies on Central Asian History, In Honor of Yuri Bregel. Devin DeWeese, ed. Bloomington, Indiana: Indiana University Research Institute for Inner Asian Studies (2001), 113- 128.

. "The Naqshbandiyya Connection: From Central Asia to India and Back (16th $19^{\text {th }}$ Centuries)." India and Central Asia: Commerce and Culture, 1500- 1800. Scott Levi, ed. New Delhi: Oxford University Press, 2007.

Guenther, Alan M.. "Hanafi Fiqh in Mughal India: The Fatawa-i Alamgiri." India's Islamic Traditions, 711- 1750. Richard M. Eaton, ed. New Delhi: Oxford University Press (2003), 209- 33.

Habib, Irfan, ed.. Akbar and His Age. New Delhi: Oxford University Press 1997.

. "Timur in the Political Tradition and Historiography of Mughal India." L'Heritage Timouride. Maria Szuppe, ed. (1997) 297- 312.

Hambly, Gavin R.G.. "Armed Women Retainers in the Zenanas of Indo- Muslim Rulers: The Case of Bibi Fatima." Women in the Medieval Islamic World. Gavin R.G. Hambly, ed. New York: St. Martin's Press (1998), 429- 468.

. Cities of Mughal India. New York: G.P. Putnam’s Sons, 1968. , ed.. Women in the Medieval Islamic World. New York: St. Martin's Press, 1998.

Howard, Douglas A.. "Ottoman Historiography and the Literature of 'Decline' of the Sixteenth and Seventeenth Centuries." Journal of Asian History 22 (1988), 52-77.

Howe, Nicholas. Migration and Mythmaking in Anglo Saxon England. Notre Dame, Indiana: University of Notre Dame, 2001.

Imber, Colin. The Ottoman Empire, 1300- 1650. New York: Palgrave Macmillan, 2002.

Jackson, Peter. The Delhi Sultanate. New York: Cambridge University Press, 1999. and Lawrence Lockhart, eds. Cambridge History of Iran VI [The Timurid and Safavid Periods] Cambridge: Cambridge University Press, 1986. 
Kahn, Paul. A Secret History of the Mongols: An Adaptation of the Yuan Cha'o Pi Shih. Francis Woodman Cleaves, tr. Boston: Cheng \& Tsui Company, 1984, 1998.

Keay, John. India, A History. New York, NY: Grove Press, 2000.

Keddie, Nickie and Rudi Matthee, eds. Iran and the Surrounding World. Seattle and London: University of Washington Press, 2002.

Khan, Iqtidar Alam. "Akbar's Personality Traits and World Outlook: A Critical Reappraisal." Akbar and His Age. Irfan Habib, ed. New Delhi: Oxford University Press, 1997.

. The Political Biography of A Mughal Noble. New Delhi: Munshiram Manoharlal Publishers, 1973.

Khosla, Ram Prasad. Mughal Kingship and Nobility. Delhi: Idarah-i Adabiyat-i Delli, 1976.

Koch, Ebba. The Complete Taj Mahal and the Riverfront Gardens of Agra. London: Thames and Hudson, Ltd. 2006.

. "Delhi of the Mughals." Mughal Art and Imperial Ideology. Ebba Koch, ed., New Delhi: Oxford University Press (2002), 163- 181.

. "The Hierarchical Principles of Shah Jahani Painting." Mughal Art and Imperial Ideology. Ebba Koch, ed. New Delhi: Oxford University Press (2002), 130- 162.

. Mughal Art and Imperial Ideology: Collected Essays. Ebba Koch, ed. New Delhi: Oxford University Press, 2002.

. "The Mughal Waterfront Garden." Gardens in the Time of the Great Muslim Empires. Attilio Petruccioli, ed. Leiden: Brill (1997), 140- 160.

Kozlowski, Gregory C.. "Private Lives and Public Piety: Women and the Practice of Islam in Mughal India." Women in the Islamic World. Gavin Hambly, ed. New York: St. Martin's Press (1998), 469- 488.

Kulke, Hermann, ed.. The State In India, 1000- 1700. Delhi: Oxford University Press, 1995.

Lal, Ruby. Domesticity and Power in the Early Mughal World. Cambridge: Cambridge University Press, 2005.

. "Historicizing the Harem: A History of Early Mughal Domestic Life." unpublished dissertation, Johns Hopkins University, 2004. 
Larson, Pier M.. "Reconsidering Trauma, Identity and the African Diaspora: Enslavement and Historical Memory in Nineteenth Century Highland Madagascar." William and Mary Quarterly $3^{\text {rd }}$ Series LVI 2 (1999), 335- 62.

Lentz, Thomas W.. "Dynastic Imagery in Early Timurid Wall Painting." Muqarnas 10 (1993), 253- 265.

. "Memory and Ideology in the Timurid Garden." Mughal Gardens. James Westcoat, Jr. and Joachim Wolschke- Bulmahn, eds. Washington, D.C.: Dumbarton Oaks (1996), 31- 57.

and Glenn D. Lowry. Timur and the Princely Vision: Persian Art and Culture in the Fifteenth Century. Los Angeles and Washington, D.C.: Los Angeles County Museum of Art and the Arther Sackler Gallery, Smithsonian Institution, 1989.

Mano, Eiji. "The Baburnama and the Tarikh-i Rashidi: Their Mutual Relationship." Timurid Art and Culture. Lisa Golombek and Maria Subtelny, eds. Leiden: E.J. Brill (1992),, 44- 47.

Manz, Beatrice Forbes. "Family and Ruler in Timurid Historiography." Studies on Central Asian History. Devin DeWeese, ed. Bloomington, Indiana: Indiana University Research Institute for Inner Asian Studies (2002) 57- 78. . "Mongol History rewritten and re-lived." REMMM 89- 90 (2002), 129- 149.

. The Rise and Rule of Tamerlane. New York: Cambridge University Press, 1999.

. "Tamerlane's Career and Its Uses." Journal of World History 13.1 (2002) 1-25.

. "Tamerlane and the Symbolism of Sovereignty." Iranian Studies 21, 1-2 (1988), $105-22$.

. "Temur and the Problem of a Conqueror's Legacy." Journal of the Royal Asiatic Society 3/8/1 (1998), 21- 41.

. "Women in Timurid Dynastic Politics." Women in Iran from the Rise of Islam to 1800. Guity Nashat and Lois Beck, eds. Champagne-Urbana, Illinois: University of Illinois Press (2003),121- 139.

Marshall, D.N.. Mughals in India: A Bibliographical Survey. New York: Asia Publishing House, 1967.

Matthee, Rudolph P.. The Pursuit of Pleasure: Drugs and Stimulants in Iranian History, 1500- 1900. Princeton, NJ: Princeton University Pres,s 2005. 
McChesney, Robert. Waqf in Central Asia, 1480- 1889. Princeton: Princeton University Press, 1991.

Mehta, Suketu. Maximum City. New York: Vintage Books, 2005.

Meisami, Julie Scott. Medieval Persian Court Poetry. Princeton, NJ: Princeton University Press 1987.

Miller, Barbara Stoler, ed. Powers of Art. Delhi: Oxford University Press, 1992.

Misra, Rekha. Women in Mughal India (1526- 1748). Delhi: Munshiram Manoharlal, 1967.

Morgan, David O.. "The 'Great "yasa" of Chingiz Khan' and Mongol Law in the Ilkhanate." Bulletin of Oriental and African Studies, In Honor of Ann Lambton 49:1 (1986), 163- 176.

. The Mongols. Cambridge, Massachusetts: Blackwell Publishers,1986, reprint 1994.

Moynihan, Elizabeth B.. "But what a happiness to have known Babur!" Mughal Gardens. James Westcoat, et al., eds. (1996), 95- 126.

Mukminova, Raziya. "Le role de la femme dans la societe de l'asia central sous les Timourides et les Sheybanides." L'Heritage Timouride, Iran-Asia Centrale-Inde, XVe-XVIIIe Siecles. Maria Szuppe, ed. Tachkent- Aiz-en-Provence, 1997.

Naqvi, H.K.. History of Mughal Government and Administration. Delhi: Kanishka Publishing House, 1990.

Nashat, Guity and Lois Beck, eds.. Women in Iran from the Rise of Islam to 1800. Champagne-Urbana, Illinois: University of Illinois Press, 2003.

Nasr, Seyyid Hossein. Sufi Essays. Albany, NY: State University of New York Press, 1991.

Nasta, Susheila. Home Truths: Fictions of the South Asian Diaspora in Britain. New York: Palgrave, 2002.

Necipoğlu, Gülru. "The Serial Portraits of Ottoman Sultans in Comparative Perspective." The Sultan's Portrait. Istanbul: Isbank, 2000.

Nizami, Khaliq Ahamad. State and Culture in Medieval India. New Delhi: Adam Publishers and Distributors, 1985.

Nizami, K. A.. "Naqshbandi Influence on Mughal Rulers and Politics." Islamic Culture 39 (1965), 41- 52. 
Paul, Jurgen. Doctine and Organization: The Khwajagan/Naqshbandiya in the first generation after Baha'uddin. ANOR 1 (1998), 1-79.

. "Forming a Faction: The Himayat System of Khwaja Ahrar."International Journal of Middle Eastern Studies 23, 4 (1991), 533- 548.

Petruccioli, Attilio ed.. Gardens in the Time of the Great Muslim Empire: Theory and Design. Leiden: Brill, 1997.

Pourafzal, Haleh and Roger Montgomery. The Spiritual Wisdom of Hafiz. Rochester, Vermont: The Spiritual Traditions 1998.

Quinn, Sholeh. Historical Writing During the Reign of Shah Abbas, Ideology, Imitation and Legitimacy in Safavid Chronicles. Salt Lake City, Utah: University of Utah Press, 2000.

Rehman, Abdul. "Garden Types in Mughal Lahore." Gardens in the Time of the Great Muslim Empires. Attilio Petruccioli, ed. Leiden: Brill (1997), 161- 172.

Richards, John. "The Formulation of Imperial Authority Under Akbar and Jahangir." The Mughal State, 1526- 1750. Muzaffar Alam and Sanjay Subrahmanyam, eds., New Delhi: Oxford University Press (1998), 126- 167.

. The New Cambridge History of India: The Mughal Empire. Cambridge University Press, 1993, repr. 1995.

Roemer, H.R.. "The Safavids." Cambridge History of Iran, VI [The Timurid and Safavid Periods] Peter Jackson and Lawrence Lockhart, eds. Cambridge: Cambridge University Press,, 1986.

Rizvi, S.A.A.. "Sixteenth Century Naqshbandi Leadership in India." Naqshbandis, Marc Gaborieau, Alexandre Popovic, Thierry Zarcone, eds. Istanbul: Isis Press $(1985 / 1990) 153-165$.

Rogers, J.M.. Mughal Painting. London: British Museum Press 1993.

Ruggles, D. Fairchild. "Humayun's Tomb and Garden: Typologies and Visual Order." Gardens, Petrucciolo, ed. Leiden: Brill (1997), 173- 186.

Rypka, Jan. History of Iranian Literature. Dordrecht: D. Reidel, 1968.

Saberi, Reza, ed. and tr.. A Thousand Years of Persian Rubaiyat. Bethesda, Maryland: IBEX Publishers, 2000.

Sarkar, Sir Jadunath. History of Aurangzib. London: Orient Longman Limited 1973. 
Savory, Roger. Iran Under the Safavids. Cambridge: Cambridge University Press, 1980.

Schimmel, Annemarie. The Empire of the Great Mughals. London: Reakton Books, LTD, 2004.

Shiva, Shahram T. Rending the Veil: Literal and Poetic Translations of Rumi. Prescott, AZ: Hohm Press, 1995

Smith, Anthony D.."Culture, Community and Territory: The Politics of Ethnicity and Nationalism.” International Affairs 72, 3 (1996), 445- 58.

. Myths and Memories of the Nation. Oxford, New York: Oxford University Press, 1999.

Soucek, Priscilla. "Timurid Women: A Cultural Perspective." Women in the Medieval Islamic World. Gavin Hambly, ed. New York: St.Martin’s Press (1998), 199- 226.

Soucek, Svat. A History of Inner Asia. Cambridge, UK: Cambridge University Press, 2000.

Soudavar, Abolala. "The Early Safavids and Their Cultural Interactions With Surrounding States." Iran and the Surrounding World. Nickie Keddie and Rudi Matthee, eds. Seattle and London: University of Washington Press (2002), 89120.

Steingass, F.. Persian-English Dictionary, New Delhi: Munshiram Manoharlal Publishers, Pvt., 2000

Streusand, Douglas E.. The Formation of the Mughal Empire. Delhi: Oxford University Press, ,1989.

Subtelny, Maria Eva. "Arts and Politics in Early Sixteenth-Century Central Asia." Central Asiatic Journal 27, 1-2 (1983) 121- 48.

. "The Curriculum of Islamic Higher Learning in Timurid Iran in the Light of the Sunni Revival Under Shah Rukh." Journal of the American Oriental Society 115, 2 (1995), 210- 36.

. "Mirak-i Sayyid Ghiyas and the Timurid Tradition of Landscape Architecture." Studia Iranica 24 (1995), 19- 38.

. "Scenes From the Literary Life of Timurid Heart." Logos Islamicos.Roger M. Savory and Dionisius A. Agius, eds. Toronto: Pontifical Institute of Medieval Studies (1984), 137- 158. 
. "The Timurid Legacy: A Reaffirmation and a Reassessment." Cahiers D'Asie Centrale 3-4 (1997), 14.

Szuppe, Maria, ed. L'Heritage Timouride, Iran-Asie Central-Inde, XVe-XViiie Siecles. Le Cahiers d'Asie Centrale Tachkent- Aix- en- Provence, 1997.

. "Women in Sixteenth Century Safavid Iran." Women in Iran. Guity Nashat and Lois Beck, eds. Champagne-Urbana, Illinois: University of Illinois Press (2003), 140- 169.

Tripathi, Ram Prasad. "The Turko- Mongol Theory of Kingship." The Mughal State, 1526- 1750. Alam and Subrahmanyam, eds. New Delhi: Oxford University Press, 1998.

Wade, Bonnie C.. Imaging Sound: An Ethnomusicological Study of Music, Art and Culture in Mughal India. Chicago and London: University of Chicago Press, 2005.

Westcoat, James, Jr. and Joachim Wolschke- Bulmahn, eds. Mughal Gardens. Washington, D.C.: Dumbarton Oaks, 1996.

Wheeler, R.E.M.. Five Thousand Years of Pakistan. London: Royal India and Pakistan Society, 1950.

Woods, John E.. The Aqquyunlu: Clan, Confederation, Empire. Salt Lake City: University of Utah Press 1999.

- "The Rise of Timurid Historiography." Journal of Near Eastern Studies 46/2 (April 1987) 81- 108.

Zarcone, Thierry. "Central Asian Influence on the Early Development of the Chishtiyya Sufi Order in India." The Making of Indo- Persian Culture. Muzaffar Alam, Francoise 'Nalini' Delvoye and Marc Gaborieau, eds. New Delhi: Manohar (2000), 99- 116. 